Gelze Serrat de Souza Campos Rodrigues

Jurandyr Luciano Sanches Ross

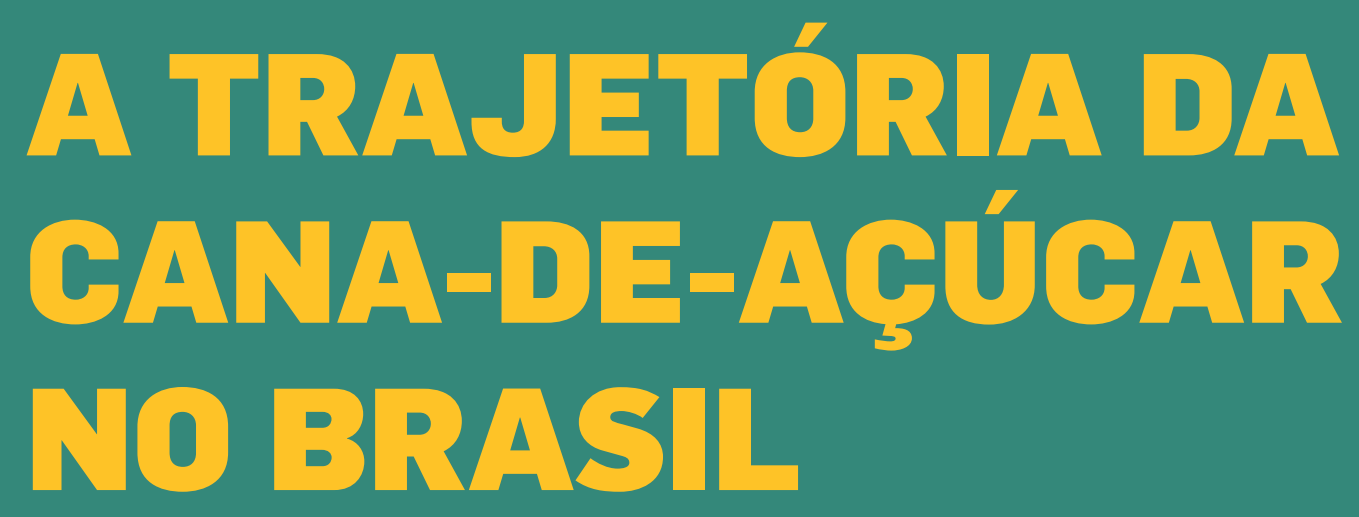

perspectivas geográfica,

histórica e ambiental

EDUFU 


\title{
A trajetória da cana-de-açúcar no Brasil perspectivas geográfica, histórica e ambiental
}

\author{
Gelze Serrat de Souza Campos Rodrigues \\ Jurandyr Luciano Sanches Ross
}

\section{SciELO Books / SciELO Livros / SciELO Libros}

RODRIGUES, G.S.S.C., and ROSS, J.L.S. A trajetória da cana-de-açúcar no Brasil: perspectivas geográfica, histórica e ambiental [online]. Uberlândia: EDUFU, 2020, 269 p. ISBN: 978-65-8608400-9. https://doi.org/10.14393/EDUFU/978-65-86084-00-9.

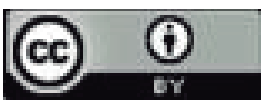

All the contents of this work, except where otherwise noted, is licensed under a Creative Commons Attribution 4.0 International license.

Todo o conteúdo deste trabalho, exceto quando houver ressalva, é publicado sob a licença Creative Commons Atribição $\underline{4.0}$.

Todo el contenido de esta obra, excepto donde se indique lo contrario, está bajo licencia de la licencia Creative Commons Reconocimento 4.0. 
A trajetória da cana-de-açúcar no Brasil:

perspectivas geográfica, histórica e ambiental 

Gelze Serrat de Souza Campos Rodrigues Jurandyr Luciano Sanches Ross

\section{A trajetória da cana-de-açúcar no Brasil:}

perspectivas geográfica, histórica e ambiental

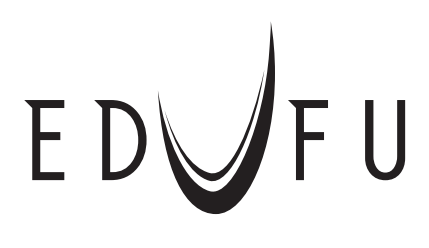


Copyright 2020 (C) Edufu

Editora da Universidade Federal de Uberlândia/MG

Todos os direitos reservados. É proibida a reprodução parcial ou total por qualquer meio sem permissão da editora.

GUFU Uூ $010 \begin{aligned} & \text { Federal de } \\ & \text { Uberlândia }\end{aligned}$

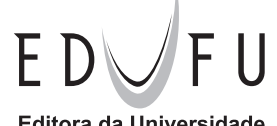

Editora da Universidade Federal de Uberlândia www.edufu.ufu.br
Av. João Naves de Ávila, 2121

Campus Santa Mônica - Bloco 1S - Térreo

Cep 38408-100 | Uberlândia - MG

Tel: (34) 3239-4293

$\begin{aligned} \text { Reitor } & \text { Conselho Editorial } \\ \text { Valder Steffen Jr. } & \text { André Nemésio de Barros Pereira } \\ & \text { Décio Gatti Júnior } \\ \text { Vice-reitor } & \text { Emerson Luiz Gelamo } \\ \text { Orlando César Mantese } & \text { Hamilton Kikuti } \\ & \text { João Cleps Júnior } \\ \text { Diretor da Edufu } & \text { Ricardo Reis Soares } \\ \text { Guilherme Fromm } & \text { Wedisson Oliveira Santos }\end{aligned}$

Equipe de Realização

Editora de publicações Maria Amália Rocha

Revisão Lúcia Helena Coimbra Amaral

Revisão ABNT Yara Ribeiro de Moura Silva

Projeto gráfico, capa e editoração $\quad$ Eduardo Moraes Warpechowski

Dados Internacionais de Catalogação na Publicação (CIP)

Sistema de Bibliotecas da UFU, MG, Brasil.

\footnotetext{
R696t Rodrigues, Gelze Serrat de Souza Campos, 1963-

A trajetória da cana-de-açúcar no Brasil [recurso eletrônico]: perspectivas geográfica, histórica e ambiental / Gelze Serrat de Souza Campos Rodrigues, Jurandyr Luciano Sanches Ross. - Uberlândia : EDUFU, 2020.

272 p.: il.

ISBN: 978-65-86084-00-9

DOI: 10.14393/EDUFU/978-65-86084-00-9

Livro formato digital.

Disponível em: http://www.edufu.ufu.br

Inclui bibliografia.

Inclui ilustraçes.

1. Geografia. 2. Geografia ambiental. 3. Cana-de-açúcar - Cultivo Brasil - História. 4. Cana-de-açúcar - Impactos ambientais. I. Ross, Jurandyr Luciano Sanches. II.Título.
} 


\title{
SUMÁRIO
}

\author{
Introdução 7
}

1 Inicia-se o percurso da cana-de-açúcar no Brasil

1.1 Apresentando a cana-de-açúcar 13

1.2 A agromanufatura açucareira e a significância das condicionantes físicas 15

1.3 A expansão da cana-de-açúcar na Depressão Periférica Paulista 32

1.4. Técnicas de cultivo canavieiro e de produção de açúcar nos engenhos banguês 42

1.5 Impactos socioambientais da agromanufatura açucareira 55

2 Uma transição sutil: dos engenhos centrais às usinas

2.1 A implantação dos engenhos centrais em terras brasileiras 67

2.2 A expansão dos engenhos centrais em Pernambuco, Bahia, Rio de Janeiro e São Paulo 75

2.3 Dos engenhos centrais às usinas 90

2.4 A geografia canavieira na época dos engenhos centrais e o surgimento das usinas 97

2.5 Inovações provenientes do engenho central 101

2.6 Impactos socioambientais dos primórdios da indústria açucareira 109 


\section{Surge o novo polo canavieiro}

3.1 O planejamento estatal do setor sucroalcooleiro brasileiro se inicia 114 3.2 São Paulo: o novo polo da indústria canavieira 123

3.3 Uma nova fase com uma velha solução: o retorno às exportações 130 3.4 A tecnificação da agricultura e a conformação de uma nova geografia canavieira 137

3.5 Impactos socioambientais da tecnificação da cultura canavieira 143

\section{A agroindústria sucroalcooleira e o proálcool}

4.1 Depois da bonança, a tempestade 151

4.2 Uma nova crise, uma nova saída: o Proálcool 157

4.3 Mais avanços tecnológicos no período do Proálcool 169

4.4 A geografia canavieira nas três primeiras fases do Proálcool 173

4.5 A desregulamentação do setor sucroalcooleiro e os impactos na geografia canavieira 176

4.6 Impactos socioambientais causados pelo Proálcool 188

5 Continuidades e descontinuidades: a agroindústria sucroenergética

5.1 A salvação da lavoura canavieira 195

5.2 A eclosão de uma nova fase: a agroindústria sucroenergética 197

5.2.1 Novas estratégias 197

5.2.2 Avanços tecnológicos e diversificação produtiva 202

5.2.3 A cana-de-açúcar na fase sucroenergética 213

5.3 A geografia canavieira no Brasil atual 217

5.4 Impactos socioambientais e a sustentabilidade da sucroenergia 221

5.4.1 Entra em cena o meio ambiente 221

5.4.2 Os impactos socioambientais 228

Conclusão: final sem fim 248

Referências 253 


\section{INTRODUÇÃO}

Cana-caiana / Cultura que o árabe propagou / Apesar dos cruzados plantarem / A cana na Europa não vingou / Mas conta a história que em Veneza / O açúcar foi pra mesa da nobreza / Virou negócio no Brasil, trazida de além-mar / E, nesta terra, o que se planta dá / Gira o engenho pra sinhô, Bahia faz girar / E, em Pernambuco, o escravo vai cantar / (Quero vê) / Quero vê descê o suco até melá / Na pancada doce do ganzá (Samba enredo do Grêmio Recreativo Escola de Samba Imperatriz Leopoldinense, 2001)

O texto acima, parte do samba enredo da escola de samba carioca Imperatriz Leopoldinense, do carnaval de 2001, ilustra bem como a cana-de-açúcar está visceralmente integrada à formação do território brasileiro e à cultura de seu povo. Por vários séculos, um de seus derivados, o açúcar, foi uma raridade luxuosa, consumido apenas pelas classes privilegiadas da Europa, que o haviam provado pela primeira vez por volta do século VIII, e o consumiam como especiaria e medicamento. Apenas no século XVIII é que ele se tornaria um produto trivial, de uso diário (Mintz, p. 38-40, 2003).

Provavelmente oriunda da Índia, a cana-de-açúcar foi levada pelos árabes e chineses para territórios localizados na costa do Mar Mediterrâneo e do Oceano Índico. Posteriormente, os cavaleiros das Cruzadas, que haviam se acostumado ao uso do açúcar no Extremo Oriente e que queriam continuar a utilizá-lo, ao retornarem para a Europa, rapidamente desenvolveram um intenso comércio do açúcar 
produzido na costa do Mediterrâneo, o qual perdurou até o início do século XVI.

A conquista de Constantinopla pelos turcos, em 1453, fez a manufatura açucareira declinar no entorno do Mediterrâneo e possibilitou o seu monopólio produtivo pelos portugueses, que já haviam iniciado o plantio da cana-de-açúcar em ilhas do Atlântico. No século XVI, a cana é levada à recém-colônia descoberta - o Brasil.

É nesse ponto que se inicia a trajetória a ser percorrida neste livro. Como bem lembra o enredo do samba, "nesta terra, o que se planta dá", foi no território brasileiro que a cana-de-açúcar e a manufatura açucareira se deram, resultando naquilo que seria denominado por Celso Furtado, em 1969, em seu livro Formação econômica brasileira, como a primeira grande empresa colonial agrícola europeia.

No Brasil, fatores especialmente favoráveis para o seu desenvolvimento foram encontrados: solos férteis, água profusa, temperaturas quentes, relevos planos e mão de obra indígena abundante, apoiados no desejo e no sonho portugueses de manter o território de onde no futuro se poderia, quem sabe, serem extraídas grandes quantidades de ouro, como ocorria do lado Oeste do Tratado de Tordesilhas.

Os canaviais começaram a ser implantados, primeiramente, nas porções litorâneas da costa brasileira e, posteriormente, também nas áreas interioranas. Os escravos, primeiramente indígenas e, posteriormente, africanos, cultivavam-na, cortavam-na e a levavam ao engenho, onde a cana era moída, o caldo aferventado até formar uma garapa, para então ser cristalizado e dar origem aos torrões de açúcar exportados para a Europa.

Continuamente arraigados à paisagem e aos diferentes arranjos econômicos, territoriais e tecnológicos, os engenhos foram, em meados do século XX, substituídos pelas usinas sucroalcooleiras, as quais, no início do século XXI, foram renomeadas como usinas sucroenergéticas. Afinal, tais complexos agroindustriais continuam a receber a cana, atualmente resultante de vários cruzamentos, cultivada e cortada mecanicamente, e que após moída, não produze apenas açúcar, mas também etanol, plásticos, e cujo bagaço é utilizado para a produção de agroenergia. 
Diferentemente de outros produtos tropicais, como o café ou o milho, o beneficiamento da cana-de-açúcar sempre exigiu um grande investimento de capitais e envolveu atividades complexas para a comercialização de seus produtos, dada a rápida deterioração da cana e do açúcar em ambientes não adequados de armazenamento e de transporte. Além disso, flutuações de preço no mercado externo e interno e políticas econômicas sempre influenciaram a expansão e a retração do setor canavieiro, que, no entanto, sempre se manteve como um dos principais da agroindústria brasileira. Tanto que, no ano de 2017, o Brasil se posicionou como o maior produtor mundial de cana-de-açúcar e de açúcar, e o segundo de etanol ${ }^{1 .}$

O que explica essa constância da cana-de-açúcar e dos seus derivados nas pautas de produção e de exportação brasileiras? Quais são as condicionantes físicas que explicam a expansão dos canaviais e, consequentemente, das unidades manufatureiras e industriais do açúcar, etanol e agroenergia em certas regiões do território brasileiro? Como esses determinantes, associados a fatores históricos, políticos e econômicos, levaram a arranjos territoriais e a impactos socioambientais diferenciados ao longo desses cinco séculos?

Essas indagações nortearam o desdobramento dos temas tratados neste livro, descortinando um longo processo iniciado no período colonial e que aglutinou enorme quantidade de variáveis de abrangência política, econômica, social e tecnológica, ancoradas nas características físicas, sobretudo hidroclimatológicas, dos solos e do relevo das áreas onde a cana-de-açúcar, os engenhos e as usinas foram implantados.

Como bem ressaltado pelo professor Maurício de Abreu no brilhante artigo "Um quebra-cabeças (quase) resolvido: os engenhos da Capitania do Rio de Janeiro - séculos XVI e XVII”, apesar da importância econômica da cana-de-açúcar no período colonial brasileiro, é paradoxal a pequena quantidade de informações acerca desse período referente a ela. Ressaltando ainda o caráter fragmentário das informações existentes, o autor pontua a quase obrigatoriedade de uma boa dose de criatividade àqueles que se aventuram na seara desse antigo mundo do

${ }^{1}$ Em 2018, os Estados Unidos produziram 56\% do etanol mundial, derivado de milho; o Brasil, 28\%; e 16\% foram de origem diversa (RFA, 2019, p. 7). 
açúcar. E, de uma certa forma, esse princípio foi seguido ao nos debruçarmos sobre as questões ambientais antes dos anos de 1950, provocadas pelo cultivo da cana-de-açúcar e pela produção de açúcar e álcool.

Certamente, muitos livros e pesquisas trataram de momentos específicos da história da expansão da cana-de-açúcar no território brasileiro, contudo há a carência na literatura de obras que expliquem as origens e as mudanças pelas quais a agroindústria canavieira passou ao longo dos séculos no Brasil e que discorram sobre os impactos ambientais oriundos da atividade nessas fases diferenciadas.

Dessa forma, a composição de informações aqui apresentadas sobre as transformações históricas, geográficas e tecnológicas relacionadas à difusão da cana-de-açúcar no Brasil é uma tentativa de preencher essa lacuna. Trajetória que se inicia com os primeiros plantios de cana-de-açúcar em São Vicente, e que se conclui nos dias atuais, sem, no entanto, encerrar as suas possibilidades futuras no território brasileiro.

Os dados geográficos, históricos, cartográficos e socioambientais foram levantados em referências bibliográficas, fontes documentais e trabalhos de campo. No extenso recorte temporal escolhido, as informações foram coletadas, correlacionadas e sistematizadas, com a perspectiva de se identificarem os elementos e os sistemas ambientais constituintes, cuja dinâmica nos desse o respaldo para o entendimento das suas fragilidades e potencialidades para o uso da cana-de-açúcar, e dos impactos ambientais decorrentes das cadeias produtivas do açúcar e do álcool.

As unidades ambientais apresentadas são constituídas de territórios que apresentam certo grau de homogeneidade fisionômica, revelada sobretudo pelo relevo, pelos solos, pela vegetação e pela densidade hidrográfica. Portanto, foram privilegiadas as áreas core de cana-de-açúcar durante os cinco séculos de sua expansão. Limites justificáveis em termos práticos, tendo em vista a diversidade e a grande quantidade de províncias e municípios pelos quais a cana-de-açúcar passou e as grandes distâncias no território brasileiro.

Nesse sentido, considerando que o Brasil apresenta uma característica que sempre favoreceu a indústria canavieira - o abastecimento 
constante de matéria-prima, devido às duas épocas de colheita por ano, decorrentes da variação climática em seu território, foi adotada como primeira base, para o recorte espacial, a divisão do país em duas grandes regiões produtoras: o Norte/Nordeste, correspondente a todos os estados localizados ao Norte do Espírito Santo, e o Centro-Sul, referente aos demais estados.

Contudo, tomando-se como suporte teórico a teoria dos sistemas, o Norte/Nordeste e o Centro-Sul abrangem unidades cores de cana-de-açúcar, menores, com especificidades muito próprias conferidas pelas características biofísicas, mas também pelo rebatimento das decisões econômicas e políticas de cada sistema ambiental menor e maior, como é o caso de Pernambuco, Bahia e Alagoas, no Norte/Nordeste; e de Rio de Janeiro, São Paulo, Minas Gerais e Paraná, no Centro-Sul, podendo esses estados serem considerados como típicos para o que aconteceu em outros estados do Brasil.

Outra questão a ser esclarecida é a adoção do conceito de impacto ambiental, conforme o entendimento de Luís Enrique Sànchez, no livro Avaliação de impactos ambientais, ou seja, qualquer modificação da qualidade ambiental resultante de alterações de processos naturais ou sociais provocados por ação antrópica e que, portanto, podem ter caráter adverso ou benéfico. Ressalta-se também que em razão da abrangência escalar e temporal utilizada, optou-se por dar maior relevância aos impactos considerados como significativos em cada época histórica, ou seja, às modificações de processos naturais ou sociais que implicaram efeitos socioambientais cumulativos ou respostas intensas do meio ambiente e registradas em algum documento pesquisado.

Dessa forma, os capítulos foram organizados em cinco momentos, histórica e geograficamente distintos, segundo um critério baseado nos contextos político, econômico e técnico/tecnológico, refletidos na organização espacial específica de cada uma das fases apresentadas e nos impactos socioambientais decorrentes.

O primeiro capítulo, "Inicia-se o percurso da cana-de-açúcar no Brasil”, aborda as origens do sistema canavieiro no Brasil e a importância dos componentes do sistema ambiental natural - água, rios, relevo, vegetação, clima - para a instalação dos primeiros canaviais e engenhos 
e para a sua difusão pelo território colonial. O segundo, "Uma transição sutil: dos engenhos centrais às usinas", apresenta o processo de transição entre os antigos engenhos e os engenhos centrais e o sistema produtivo usineiro, demonstrando o impacto das inovações técnicas na cultura canavieira e na produção de seus derivados ao final do período monárquico e na Primeira República. O capítulo três, "Surge o novo polo canavieiro", trata do planejamento do setor sucroalcooleiro brasileiro, iniciado no governo de Getúlio Vargas, e do surgimento de um novo polo da indústria canavieira, que se desloca do Nordeste para São Paulo, avançando até os anos de 1970, quando ocorre a crise do petróleo. O quatro, "A agroindústria sucroalcooleira e o Proálcool”, discute a implantação do Proálcool e a grave crise vivenciada pelo setor no final da década de 1990. O capítulo cinco, "Continuidades e descontinuidades: a agroindústria sucroenergética”, trata do cenário tendencial após a desregulamentação do setor e da introdução da tecnologia flex fuel. Ao mesmo tempo, apresenta as novas características do setor e a valorização das exigências ambientais.

Por fim, não poderíamos deixar de agradecer à família e aos amigos, pelo apoio afetivo, e a todas as pessoas, instituições e organizações que nos ajudaram nesta tarefa, não tão longa, mas extremamente concentrada e vigorosa de pesquisa e redação. Ao CNPq, pela bolsa de pós-doutorado sênior; ao Departamento de Geografia da FFLCH USP, pelo acolhimento do projeto e pelo apoio de seus funcionários, bibliotecas e laboratórios; e ao Instituto de Geografia da Universidade Federal de Uberlândia, pela liberação de um dos autores no período de estágio de pós-doutoramento. À Profa. Dra. Vera Ferlini e à sua equipe, pela recepção e disponibilização de informações a respeito do Engenho São Jorge dos Erasmos; a Jaime Finguerut, ex-assessor técnico da Presidência do Centro de Tecnologia Canavieira (CTC); e ao Sr. José Roberto Venturi, ex-diretor técnico da Superintendência de Meio Ambiente da Secretaria de Meio Ambiente do Estado de Minas Gerais, pelas entrevistas concedidas. Às Divisões de Sustentabilidade das Usinas Coruripe e BioFlex, Alagoas, por aceitarem nossas visitas técnicas, e a Thales e Léo, pelo amor que impulsiona a prosseguir adiante. 


\section{INICIA-SE O PERCURSO DA CANA-DE-AÇÚCAR NO BRASIL}

\subsection{Apresentando a cana-de-açúcar}

A cana-de-açúcar foi descrita primeiramente por Linneu, em 1753, que lhe denominou genericamente de Saccharum (Szmrecsányi, 1979, p. 110). Por ser uma planta de clima tropical, a faixa principal de sua distribuição geográfica está entre as latitudes $35^{\circ}$ Norte e $35^{\circ}$ Sul, sendo o Brasil seu maior produtor, seguido pela Índia e pela China, segundo dados da Organização das Nações Unidas para Agricultura e Alimentação - FAO (2012, p. 174).

A cana cresce em forma de touceiras, constituídas por uma parte aérea e outra subterrânea. Da parte aérea fazem parte os colmos, as folhas e as flores. A parte subterrânea é constituída pelas raízes e pelos rizomas, de onde sai uma nova touceira após o corte da cana (Szmrecsányi, 1979, p. 110-111).

O colmo é a parte principal da cana, pois é dele que se extrai o caldo, de onde se inicia a produção do açúcar e do álcool. O colmo tem forma cilíndrica e atinge na primeira rebrota cerca de $2 \mathrm{~m}$ de altura, mas pode alcançar até $6 \mathrm{~m}$, no caso da variedade atualmente denominada cana energia. A composição química do colmo de uma cana madura, normal e sadia, é em média de 70\% de água, 15\% de fibras (bagaço), 13\% de sacarose (açúcar) e 2\% de substâncias diversas (FAO, 2012, p. 174).

As folhas da cana ficam rigidamente fixadas nos colmos por meio de uma bainha. São elas que realizam a respiração, a transpiração e a elaboração dos açúcares da planta. As folhas, antes do advento das no- 
vas tecnologias de processamento industrial da cana, eram separadas do colmo após o corte, sendo queimadas ou utilizadas como forragem para o gado. No século XX, a partir da década de 1970, passaram a ser queimadas antes da colheita, com o uso do fogo. Atualmente, nas colheitas mecanizadas, são cortadas e mantidas na maior parte das vezes no solo, como cobertura.

O plantio da cana-de-açúcar se dá por meio de mudas, denominadas toletes, e o seu desenvolvimento apresenta várias fases. A primeira fase, a germinação (ou brotação), ocorre em torno de 20 a 30 dias após o plantio, quando o broto (colmo primário) se desenvolve em direção à superfície do solo. Simultaneamente, as raízes do tolete plantado surgem e há o aparecimento das primeiras folhas. Na segunda fase, perfilhamento, ocorre a emissão dos colmos secundários, terciários, e a formação da touceira. Após a formação de todos os perfilhos, iniciase a fase de crescimento da cana, quando a planta ganha altura, há o aumento da matéria seca total e ocorre o acúmulo de açúcar na base. Após a planta atingir altura igual ou superior a $2 \mathrm{~m}$, começa a fase de maturação, quando ela cessa seu crescimento e ocorre a concentração de açúcar. Nessa fase, as folhas superiores ficam amareladas e as inferiores secam (Figura 1). É o momento da colheita (Gascho et al, 1983, p. 445-479; Aude, M. I. S., 1993).

As fases de desenvolvimento da cana são fortemente influenciadas por vários fatores, tais como estado nutricional, tratos culturais e espécies utilizadas no plantio. No âmbito geográfico, um fator extremamente importante é a condição climática. A deficiência hídrica impede a brotação e o perfilhamento, assim como o excesso de água faz com que ocorra a fermentação do tolete e o menor perfilhamento. O período de crescimento exige 800 a $2.000 \mathrm{~mm} /$ ano de água. Em relação à temperatura, o ponto ótimo para o desenvolvimento da planta gira em torno dos $30^{\circ} \mathrm{C}$. Diferentemente, a fase de maturação exige temperaturas mais baixas ou déficit hídrico, para que a planta paralise seu crescimento e ocorra a acumulação de açúcar (FAO, 2012, p. 177; Aude, M. I. S., 1993). 
Figura 1. Fases de desenvolvimento da cana-de-açúcar.

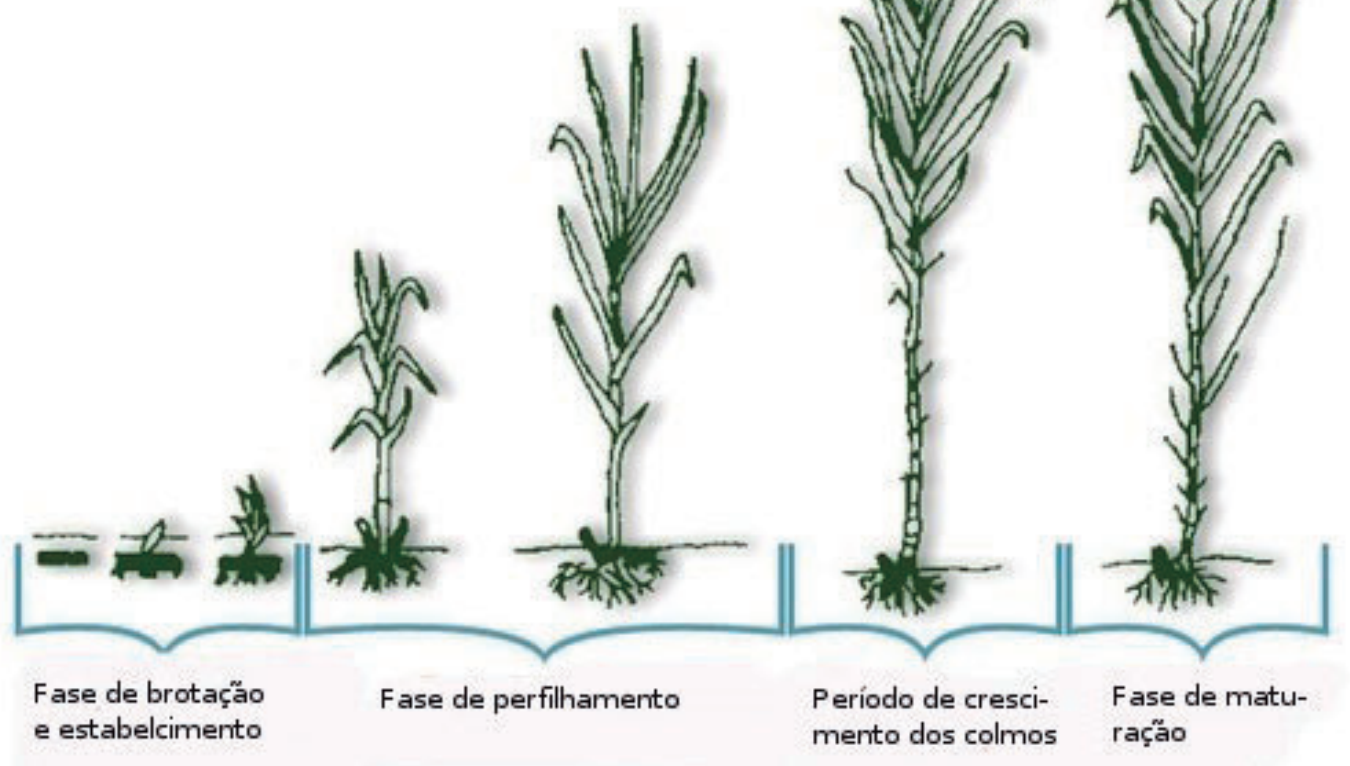

Fonte: Gascho e Shih, 1983. Org.: dos autores, 2019.

\subsection{A agromanufatura açucareira e a significância} das condicionantes físicas

Apesar de a faixa intertropical do planeta Terra caracterizar-se por acentuadas diferenças climáticas e botânicas, o Brasil possui grande extensão de seu território contemplada por uma relativa regularidade dos índices pluviométricos e de umidade, que não sente os efeitos acentuados da continentalidade e não se vê sujeita a precipitações escassas. Tal característica repercutiu na densa rede hidrográfica e nos solos de grande parte do país (Ab’Sáber, 2003, p. 66/67), extremamente propícios à expansão da cana-de-açúcar e, portanto, ao desenvolvimento de organizações produtivas, comerciais, técnicas e sociais complexas, inicialmente denominadas engenhos banguês.

Embora o Brasil tenha sido descoberto em 1500, até o terceiro decênio do século XVI, não apresentou grande interesse para Portugal, 
exceto pela extração do pau-brasil, em trechos do litoral onde a árvore era mais abundante. No entanto, a disputa com corsários franceses que traficavam a espécie brasileira para a Europa e a decadência do comércio com o Oriente, em virtude da concorrência com outras nações europeias, impulsionou a formulação de estratégias por parte da Coroa portuguesa no sentido de garantir a defesa da sua colônia e dos potenciais lucros advindos de produtos tropicais ou de metais preciosos (Piletti, 1996; Ferreira, 1996).

A partir desse momento, em que a face atlântica do território brasileiro começou definitivamente a fazer parte do rol dos interesses portugueses, passou a haver a seleção de locais mais favoráveis à efetivação do processo de colonização, tendo em vista o litoral extenso e pouco recortado do Brasil. Pontos foram facilmente identificados, já que pouco numerosos, como as baías de Todos os Santos, da Guanabara, de Santos, e a foz do rio Capibaribe. A opção por tais lugares foi baseada nas características físicas adequadas à atracagem de navios e à instalação de portos, bem como na presença das feitorias, estabelecidas na Terra de Vera Cruz desde 1500.

Nessas condições, na Baía de Santos, grande e aberta reentrância do litoral sudeste brasileiro, encontrava-se a Ilha de São Vicente, para onde, em 1530, Martim Afonso de Sousa foi enviado para, dentre outros objetivos, iniciar a base da colonização efetiva brasileira por meio da instalação de núcleos de povoamento e defesa. Para tanto, se impunha a necessidade da escolha de um produto que estimulasse a permanência dos colonizadores. Um produto que fosse apreciado pelo mercado europeu, fácil de produzir, de comercializar e adaptável às condições ambientais brasileiras (Piletti, 1996; Ferreira, 1996).

Há alguns anos, os portugueses haviam iniciado a produção de açúcar, uma das especiarias mais apreciadas pelos europeus, nas suas colônias insulares do Atlântico (Ilha da Madeira e Açores), cujo ambiente era muito similar ao do Brasil. A prévia experiência exitosa, associada à disponibilidade de terras e de mão de obra indígena na nova colônia, foi um fator decisivo para a opção pela cana-de-açúcar como primeiro produto a ser cultivado em terras brasileiras (Furtado, 1969, p. 10). 
Cercada por duas barras, a de São Vicente, mais rasa, e a de Santos, mais ampla e profunda, a Ilha de São Vicente foi palco da primeira iniciativa efetiva de cultivo da cana-de-açúcar e de instalação de engenhos em território brasileiro.

A Ilha de São Vicente, com cerca de $57 \mathrm{~km}^{2}$, pode ser considerada "como um vasto tampão que separa as áreas ocupadas por manguezais, que se desenvolvem desde as proximidades das bases da Serra do Mar, e o oceano" (Penteado, 1965, p. 12). A dificuldade da rede de drenagem para alcançar o mar fez com que vários braços de água surgissem no entorno da ilha, como o Mar Pequeno, os Largos da Pompeba e do Caneú. O obstáculo de escoamento, associado à grande quantidade de materiais em suspensão, à pequena declividade e à proximidade com o mar, determinou consequentemente a existência de vastas áreas de manguezais no centro, Noroeste e Oeste da ilha, bem como a existência de vários cursos d'água que a atravessam por meio de longos meandros (Penteado, 1965, p. 120).

Na parte central da ilha, o Maciço de São Vicente se destaca, com altitude média de $200 \mathrm{~m}$ a $220 \mathrm{~m}$ (Penteado, 1965, p. 14), formado principalmente por granitos, gnaisses e xistos (Queiroz Neto e Küpper, 1965, p. 70). É formado por um conjunto de morros que recebem denominações locais, como Morro de Nova Cintra, Morro de São Bento e Monte Serrat. Contudo, a maior parte do terreno insular é dominada pela planície marinha, cujos sedimentos provenientes das ondas que rebatem na costa meridional da ilha deram origem aos depósitos arenosos das praias e restingas.

Dessa forma, observa-se que grande parte dos solos e do relevo da ilha era inapropriado para o plantio da cana-de-açúcar. Cerca de $15 \%$ eram morros com declividades elevadas. A planície marinha, com Neossolos Quartzarênicos e Organossolos Tiomórficos pouco férteis, apresentava problemas devido à salinidade, decorrente da ação das marés, e à hidromorfia, por causa da pouca profundidade do lençol freático, que na área atinge no máximo $2 \mathrm{~m}$ de profundidade. Restavam para serem aproveitados pelo plantio canavieiro apenas as pequenas planícies fluviais dos cursos d'água, cobertos por Neossolos Flúvicos e Gleissolos Tiomórficos ou os depósitos coluvionares, em 
forma de rampa, com Argissolos Vemelhos e Amarelos e Cambissolos, formados na base dos morros.

A explicação para a escolha da ilha como ponto inicial da efetivação da colonização portuguesa, portanto, deve ter estado muito mais provavelmente ligada à estratégia de manutenção do território no litoral próximo ao limítrofe do trecho Sul do Tratado de Tordesilhas do que às condições físicas propícias ao cultivo da cana-de-açúcar.

Fato indiscutível é que desde o início do ciclo do açúcar no Brasil, o local para a instalação dos engenhos era escolhido com bastante rigor, pois fatores naturais como relevo, solos e pluviosidade eram determinantes para uma boa produção canavieira. Como elucidado anteriormente, o clima é um fator natural importante, pois a cana necessita de uma estação úmida para o seu plantio e crescimento, e de uma estação seca para o aumento do teor de sacarose. Além disso, a existência de um período sem chuvas intensas era importante, pois facilitava o transporte da cana até o engenho e possibilitava o uso da madeira nas fornalhas. Em relação aos solos, os salinos, muito arenosos e úmidos, impossibilitavam o cultivo da cana-de-açúcar, e o relevo dissecado dificultava o plantio e o transporte das canas do canavial até o engenho, inicialmente realizado pelos indígenas, que as carregavam nas costas.

A localização era condicionada também pela proximidade dos corpos d'água, cujos cursos facilitavam o acesso aos canaviais e aos locais onde o açúcar era exportado, bem como pela obtenção da água necessária ao movimento da moenda, no caso de engenhos movidos à força hidráulica, à dessedentação dos animais e às demais atividades do engenho. Outro fator fundamental era a existência de florestas que pudessem suprir a necessidade de lenha para as fornalhas e de madeira para as edificações.

Seguindo esse modelo e tomando-se como exemplo um dos primeiros engenhos instalados no Brasil, a localização do Engenho de São Jorge dos Erasmos, na Ilha de São Vicente, é uma amostra da preocupação dos colonizadores com as condições favoráveis à instalação dessas unidades produtivas.

Diante do quadro natural que se apresentava, o sopé do Morro de Nova Cintra, na vertente Oeste, foi o lugar escolhido para a implantação 
do Engenho dos Erasmos, pois era onde o Maciço de São Vicente possuía uma reentrância e as vertentes do morro terminavam em um comprido patamar, próximo ao rio São Jorge. Lá, os depósitos coluvionares localizados na base do morro e a planície fluvial do rio São Jorge forneceram o substrato requerido para o plantio das primeiras mudas de cana-de-açúcar. O Morro de Nova Cintra e a presença da Floresta Pluvial Atlântica, que o cobria, dificultavam os ataques indígenas e a floresta fornecia a madeira para as fornalhas, edificações e outras necessidades do engenho. As rochas cristalinas retiradas do Morro de Nova Cintra propiciaram a construção de uma sede sólida, localizada em uma plataforma do terreno, cujos vestígios podem ainda ser visitados (Figura 2), criando o aspecto de proeminência e domínio sobre a paisagem ao redor. Ao mesmo tempo, as águas do rio foram captadas para o funcionamento do engenho e utilizadas para o transporte da produção açucareira até o pequeno porto, localizado na Barra de São Vicente.

Figura 2. Ruínas do Engenho São Jorge dos Erasmos, localizado em São Vicente, São Paulo.

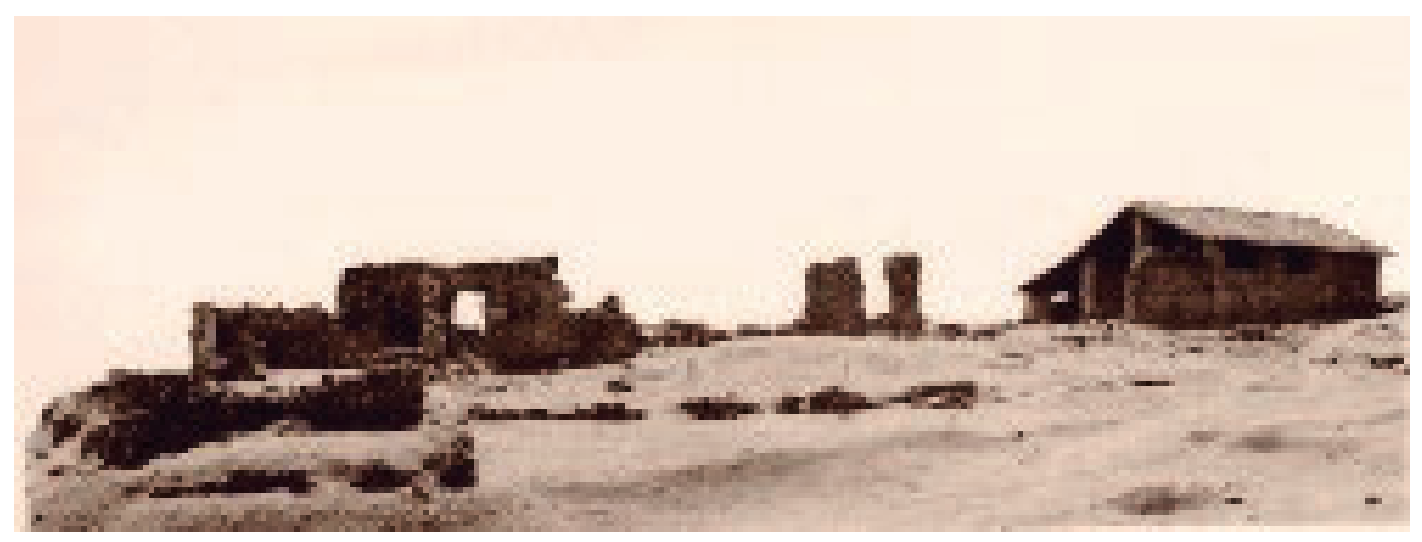

Fonte: Acervo do Monumento Nacional Ruínas Engenho São Jorge dos Erasmos.

Com a ajuda de pequenas embarcações ou de animais, o açúcar seguia até a Barra de Santos, maior e mais profunda, onde as embarcações transoceânicas chegavam.

Na primeira colheita, Martim Afonso e seu irmão, Pero Lopes de Souza, firmaram sociedade com comerciantes flamengos, formando a Sociedade dos Armadores do Trato, a qual pode ser considerada como a primeira empresa agroaçucareira do Brasil, responsável pela instalação 
dos primeiros engenhos, pela exportação do açúcar português, produzido na Capitania de São Vicente, e pela importação das especiarias advindas da Europa, vendidas aos portugueses (Reis, 1999, p. 64). De fato, até $1580^{2}$, a produção de açúcar nas colônias portuguesas foi em grande parte financiada por banqueiros genoveses e beneficiada e distribuída, no Norte da Europa, por comerciantes flamengos.

Mas era preciso a criação de outras vilas em todo o litoral brasileiro para garantir a posse da Colônia. Não tendo recursos econômicos para tal empreitada, a Coroa portuguesa, em 1534, implementou no Brasil o sistema de Capitanias Hereditárias, processo de colonização também já adotado na Ilha da Madeira e nos Açores.

O Brasil foi dividido em imensos lotes de terras, doados, em caráter vitalício e hereditário, à pequena nobreza portuguesa pelo rei, que delegava a seus donatários a colonização e a exploração. Desde o início da repartição das Capitanias Hereditárias ficou evidente o interesse da Coroa na instalação da indústria açucareira, delegando aos seus donatários a tarefa de colonização, mas reservando para si algumas vantagens, como a tributação de $10 \%$ sobre o açúcar produzido em terras brasileiras.

Os donatários recebiam privilégios jurídicos e fiscais para a implantação de engenhos no prazo de três anos, tais como: isenção de taxas sobre a produção de açúcar, exclusividade na fabricação de moendas e engenhos d'água, honrarias e títulos, escravização dos indígenas em número ilimitado e autorização para exportá-los para Portugal, permissão para autorizar a construção de engenhos e para receber tributos pela comercialização dos produtos fabricados (Piletti, 1996; Ferreira, 1996; Furtado, 1969, p. 45; Schwartz, 1988, p. 35).

Os titulares das Capitanias Hereditárias, por seu turno, promoviam a distribuição de suas terras por meio da carta de sesmaria, a colonos que deveriam formar roças, fazendas (propriedades maiores voltadas ao cultivo de produtos exportáveis, como a cana e o gengibre, ou à criação de gado) e/ou instalar engenhos (Schwartz, 1988, p. 36). Todos os proprietários de engenhos eram responsáveis pelo povoa-

\footnotetext{
${ }^{2}$ Entre 1580 e 1640, na chamada Dinastia Filipina, Portugal e suas colônias ficaram sob domínio da Coroa Espanhola.
}

20 - A trajetória da cana-de-açúcar no Brasil 
mento de sua sesmaria, bem como pela proteção daqueles que nela residissem, beneficiando a cana dos seus lavradores (Furtado, 1969, p. 45; Schwartz, 1988, p. 35).

Outra área selecionada pelos colonizadores europeus para a conquista do território recém-descoberto foi a Baía da Guanabara. Embora os portugueses tenham cruzado a Barra do Rio de Janeiro em 1502, foram os franceses que fundaram, em 1555, na atual Ilha de Villegagnon, a capital da França Antártica. Com isso, Portugal, impelido a organizar expedições para rechaçá-los, após sua expulsão, fundou São Sebastião, em 1565 (Amador, 1992, p. 212; Fridman, 1999, p. 87).

À semelhança de outras áreas do litoral brasileiro, o clima quente, com precipitações de 1.000 a $1.500 \mathrm{~mm}$, associado às características dos solos - derivados de depósitos aluvionares nas planícies dos rios e coluvionares nas bases dos morros e colinas -, foi favorável à existência de áreas propícias ao cultivo da herbácea na Baía de Guanabara (Amador, 1992, p. 219).

Diferentemente da Baía de Santos, o Recôncavo da Guanabara era limitado por restingas, que aprisionavam lagunas e brejos, a maior parte cobertas por mangues, aptas ao cultivo canavieiro somente após executadas obras de drenagem realizadas pelos escravos dos senhores de engenho (Bernardes, 1995, p. 23; Amador, 1992, p. 203/219).

Mais extensa do que a planície de São Vicente, a planície de Guanabara compreendeu canaviais de relativa importância, o que fez com que o Rio de Janeiro se tornasse um importante entreposto comercial e porto exportador para a metrópole (Bernardes, 1995, p. 26). A cana-de-açúcar expandiu-se pelas atuais Lagoa de Rodrigo de Freitas, Barra da Tijuca e Jacarepaguá. Vários portos locais se estabeleceram, como os de Meriti, Iguaçu, Inhomirim, Suruí, Magé, Guaxindiba, Iriri, Pilar ou Estrela, e Porto das Caixas, até onde a produção de açúcar dos engenhos chegava, para depois ser escoado até armazéns localizados próximos à cidade do Rio de Janeiro, de cujos ancoradouros (Figura 3) seguia para os navios que encaminhavam a produção açucareira até a metrópole (Fridman, 1999, p. 87; Amador, 1992, p. 219). A função de porto açucareiro do Rio de Janeiro findou apenas no século XIX, quando o café superou a importância do açúcar na economia exportadora. 
Figura 3. Mapa do entorno da Baía da Guanabara, com indicação de prováveis áreas de plantio de cana-de-açúcar nos séculos XVII e XVIII.

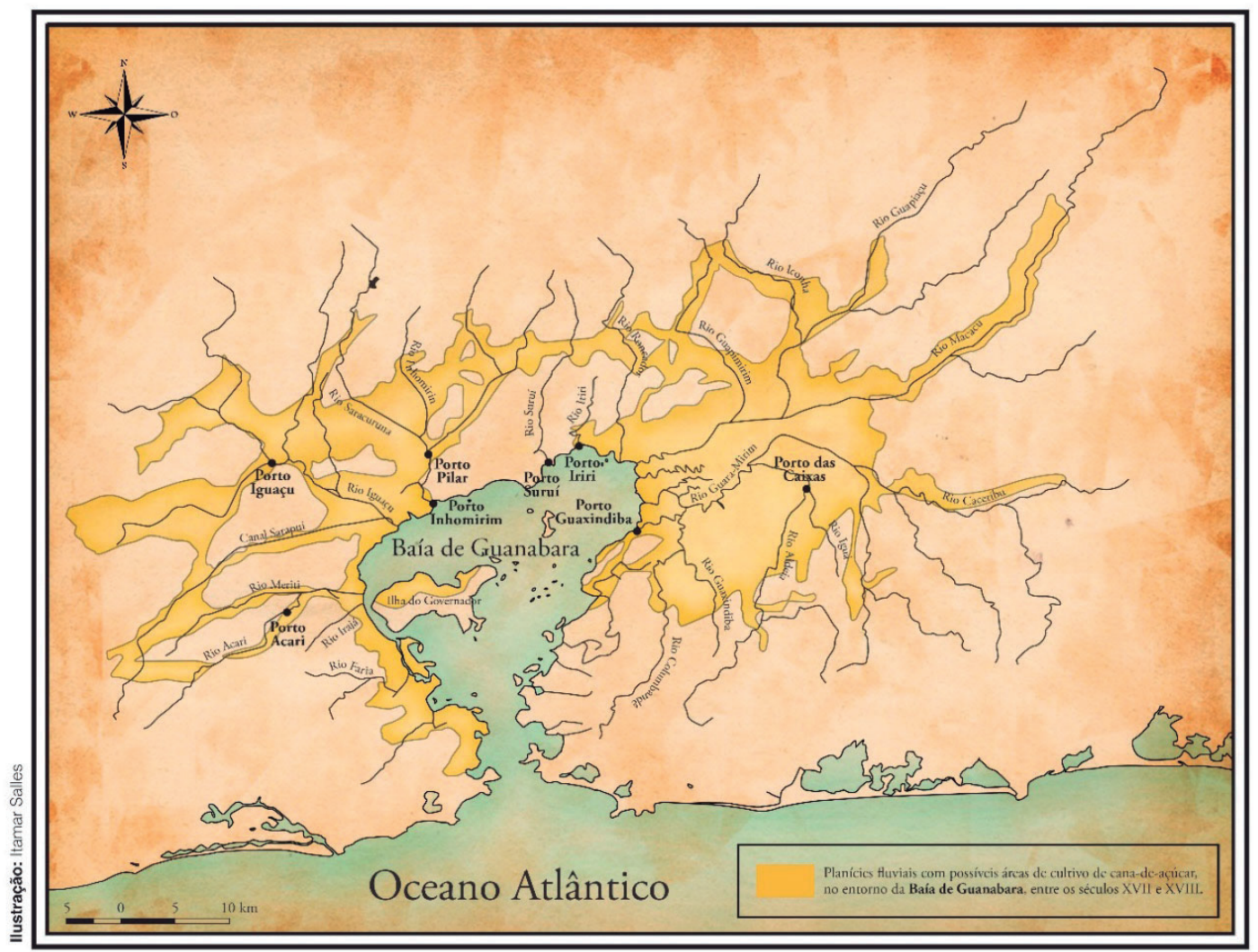

Fontes: JICA, 2002, p. 2-1, 2-2, 2-4; FRIEDMAN, 1999, p. 86; BERNARDES, 1995, p. 24. Org.: dos autores, 2016.

Acompanhando a linha costeira, a expansão da cana se deu sobre as planícies aluvionares litorâneas até o Rio Grande do Norte. Na costa setentrional do Brasil, apenas pequenos centros de pouca importância, no Maranhão e na foz do rio Amazonas, foram instalados. Em direção ao interior, a cana se propagou até o Planalto da Borborema, mantendo-se os tabuleiros costeiros como "fronteiras mortas" (Melo, 1956, apud Andrade, 1958, p. 123) até os anos de 1960.

De maneira geral, o Nordeste pode ser subdividido em quatro unidades distintas, sobretudo pelos seus índices pluviométricos, que se refletem nas suas diferentes paisagens e nas formas de ocupação econômica: a Zona da Mata, o Agreste, o Sertão e o Meio-Norte (Andrade, 2005, p. 38). Das quatro, a primeira - a Zona da Mata - era a que apresentava as características físicas mais apropriadas para o cultivo canavieiro, ou seja, clima tropical estacional, solos naturalmente férteis e abundância de água. 
A Zona da Mata nordestina ou, na denominação de Josué de Castro (1946), o Nordeste Açucareiro, corresponde

à faixa úmida oriental grosseiramente delimitada a $\mathrm{W}$ pela isoieta de 1.00omm. Ao Norte ocorrem suas primeiras manifestações no baixo vale do rio Ceará-Mirim (Rio Grande do Norte), e, para o sul, não se detendo no limite convencional da região nordestina (Baixo São Francisco), alonga-se pelo Estado de Sergipe e Norte da Bahia até o recôncavo da baía de Todos os Santos. Possui largura muito variável: 50 a $120 \mathrm{~km}$, aproximadamente. (Melo, 1962, p. 510).

Ela é constituída por terrenos de origem sedimentar e cristalina, que derivam em sistemas ambientais bastante característicos. Em rochas cristalinas, colinas ${ }^{3}$ entremeiam a rede de drenagem, com solos argilosos e sílico-argilosos, caracterizando o que Lacerda de Melo (1962) denominou de "mar de colinas". Ainda em terrenos cristalinos, tem-se a presença de aplainamentos interfluviais quase horizontais, com solos arenosos, sem aptidão agrícola para a cultura canavieira. Em sedimentos terciários, em geral da Formação Barreiras, se estendem os tabuleiros,

espécie de baixo platô litorâneo, com altitudes de 30 a 40 metros no litoral até 100 metros ou mais no rebordo ocidental, formando geomorfologicamente uma superfície correlativa à das chãs do cristalino. Arenosos, em regra mais arenosos do que as das chãs, são pouco produtivos [...]. Neles o revestimento florístico primitivo indica o grau de fertilidade: os recobertos pela vegetação de cerrados (mais arenosos), comuns no Norte de Pernambuco, na Paraíba e no Rio Grande do Norte, de baixa fertilidade, são praticamente incultos; os de cobertura florestal (menos arenosos), frequentes nas Alagoas, são mais susceptíveis de aproveitamento agrícola. (Melo, 1962, p. 512-513).

\footnotetext{
${ }^{3}$ A Resolução CONAMA n ${ }^{0}$ 303/2002 considera como morro a elevação do terreno com cota do topo em relação à base entre 50 a $300 \mathrm{~m}$ e declividade superior a aproximadamente $17^{\circ}$. Baseado nessa regulamentação, temos que as colinas são pequenas elevações, com desnível menor que $50 \mathrm{~m}$ e declividades menores que $17^{\circ}$, enquanto os morros são elevações com desnível entre 50 e $300 \mathrm{~m}$ e declividades superiores a $17^{\circ}$ (ROSS, 2015).
} 
No Rio Grande do Norte e na Paraíba, a vegetação florestal ombrófila, ou seja, a Zona da Mata, apresentava originalmente pequena extensão, ficando circunscrita às margens dos rios que deságuam no Oceano Atlântico. Nos interflúvios tabulares arenosos dominava o cerrado, onde era desenvolvida a pecuária extensiva, atividade complementar à atividade canavieira que se concentrava nas planícies dos rios Ceará-Mirim, Trairi, Mamanguape e Paraíba do Norte. A paisagem era tão contrastante entre os tabuleiros e as planícies que esses rios passaram a ser denominados "rios-de-açúcar" (Andrade, 2005, p. 40).

Mas, com efeito, entre as Capitanias Hereditárias nordestinas, as que mais se destacaram na atividade açucareira do século XVI até o início do século XIX foram as de Pernambuco e da Baía de Todos os Santos. A Capitania de Pernambuco abrangia o atual estado de Alagoas, indo desde a margem esquerda do rio São Francisco até a foz do rio Igarassu, estendendo-se até o meridiano de Tordesilhas. Esse limite foi alterado apenas em 1817, com a perda de mais da metade de seu litoral para a província de Alagoas, mantendo praticamente os mesmos limites ao Norte (Perruci, 1978, p. 97).

Na Capitania de Pernambuco, os primeiros engenhos foram instalados em 1535, sob os auspícios do donatário Duarte Coelho, que também iniciou a fundação das Vilas de Igarassu e Olinda (Andrade, 2005, p. 72). A partir desse momento, foi estabelecido o ponto de partida para o desenvolvimento da cultura canavieira na região e para a ocupação do litoral setentrional brasileiro.

O sucesso do negócio açucareiro foi tão grande que incentivou a migração de colonos portugueses e de outras capitanias, como Ilhéus e Porto Seguro, fazendo com que, em 1585, Pernambuco contasse com 66 engenhos e com o principal porto de exportação do açúcar nordestino para Portugal - o Porto de Recife (Schwartz, 1988, p. 33; Oliveira, 1972, p. 51; Andrade, 1994, p. 104).

Pernambuco era favorecido pelas extensas planícies fluviais dos rios Capibaribe, Ipojuca e Berberibe, com solos apropriados e água abundante para os engenhos reais. Além disso, estava situado em posição geográfica convenientemente mais próxima da Europa, o que 
converteu a capitania no centro açucareiro brasileiro mais importante, posição mantida até meados do século XX (Schwartz, 1988, p. 33; Schwartz, 2005, p. 80; Oliveira, 1972, p. 51; Andrade, 1994, p. 104).

A Zona da Mata pernambucana, diferentemente da potiguar e da paraibana, apresentava-se contínua, estreitando-se rapidamente na direção S-N, situando-se entre o Planalto de Borborema e o litoral. Devido às condicionantes climáticas e aos tipos de solos predominantes, apresentava-se diversa ao Sul e ao Norte de Recife, bem como à medida que se distanciava do litoral. Na porção setentrional, o índice pluviométrico menor "permitiu a conservação de grandes porções das áreas aplainadas no terciário, formando as chamadas 'chãs', as quais se alternam com morros, colinas e vales fluviais" (Andrade, 2005, p. 4) cobertos pela "mata seca", cuja floresta nos meses de estio (janeiro a março) fica desfolhada e com cor cinzenta. Os solos são arenosos, pouco férteis, o que impediu a expansão da cana-de-açúcar até o advento de tecnologias que permitiram o seu cultivo a partir do século XX (Figura 4).

Ao Sul de Recife, a maior pluviosidade permitiu o desenvolvimento da floresta perenifólia ou "mata úmida" sobre o relevo colinoso de embasamento cristalino que se estende até próximo do oceano Atlântico (Andrade, 2005, p. 41; Melo, 1962, p. 513). A explicação para a maior pluviosidade desse trecho pode ser atribuída à direção perpendicular dos ventos alísios de Sudeste em relação à costa litorânea, incidindo diretamente no litoral. No inverno, massas polares do Sul se incorporam aos alísios, produzindo chuvas mais abundantes ainda em todo o litoral oriental e mais incisivamente nessa região pernambucana (Guerra, 1955, p. 483). Nesse trecho, os solos argilosos que predominam na paisagem da Zona da Mata úmida pernambucana possibilitaram o avanço da cana-de-açúcar.

Nos terrenos do atual estado de Alagoas, a paisagem novamente se modifica, tendo em vista a redução dos índices pluviométricos e o surgimento de

tabuleiros cortados pelas várzeas amplas do Manguaba, do Camarajibe, do Santo Antônio, do Mundaú, do Paraíba do Meio, do São Miguel, do 
Figura 4. Estado de Pernambuco, com indicação de possíveis áreas de ocorrência de cana-de-açúcar desde o final do século XVI.

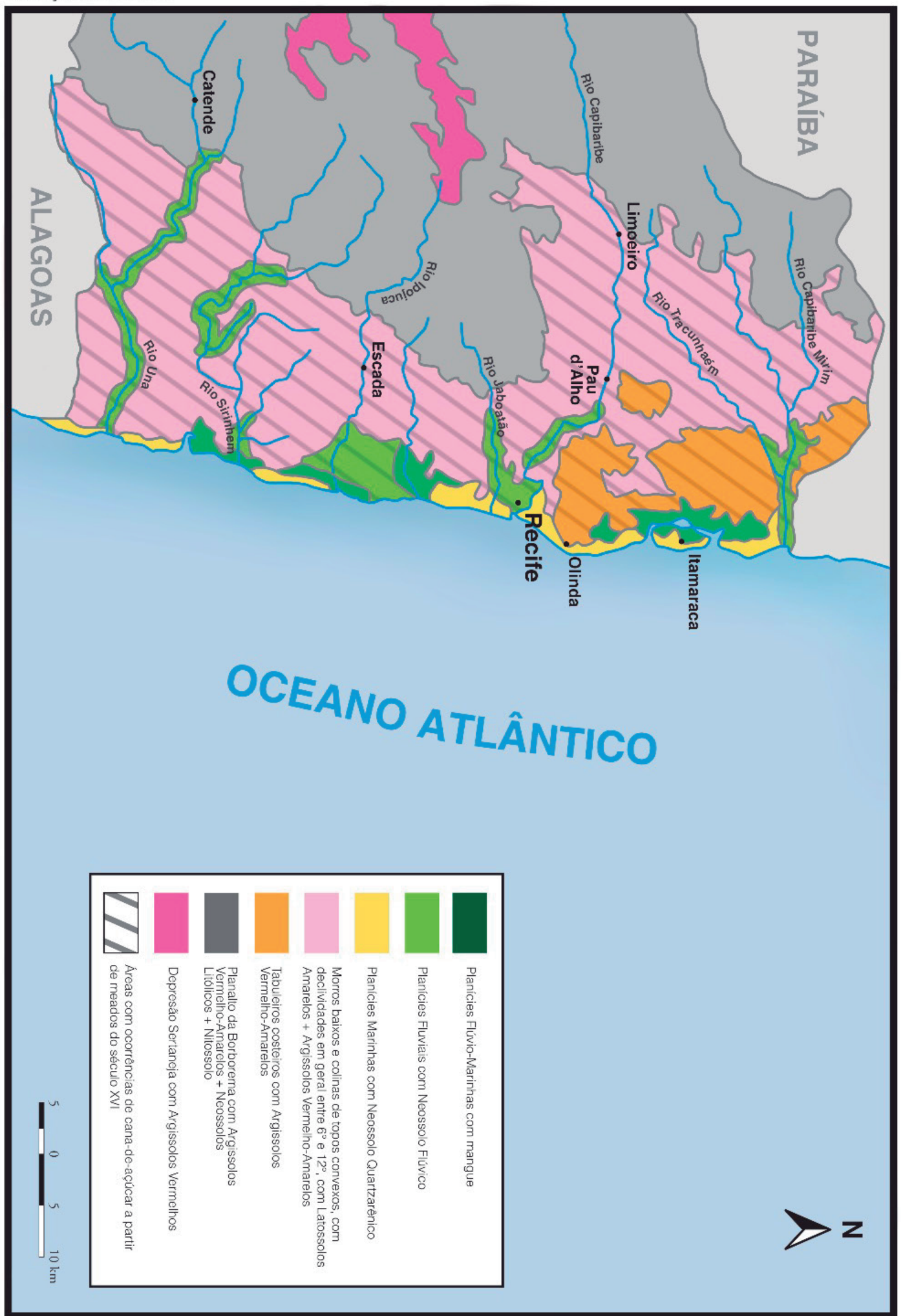

Fontes: BRASIL, 1983; BRASIL, 1983a. Org.: dos autores, 2016. 
Jiquiá e do Coruripe. Várzeas que estão sempre a necessitar de drenagem para que possam ser cultivadas e que nas proximidades da foz se apresentam afogadas e invadidas pelo mar até alguns quilômetros para o interior. (Andrade, 2005, p. 41).

Contudo, desde meados do século XVI a agricultura canavieira foi introduzida, do mesmo modo que em Pernambuco, nos Neossolos Flúvicos das planícies de rios, provavelmente nas áreas em que a inundação não era intensa, como bem ilustra Diégues Júnior (1949) quando se refere aos rios alagoanos:

Os rios não eram somente os vales férteis, através de cujas margens os canaviais gostosamente se estendiam, como se estendem ainda hoje; eram também os caminhos, por onde as canoas ou as barcaças navegavam, fazendo o comércio do açúcar. E até as próprias barcaças se construíam tendo como referência de tamanho o número de sacos ou de caixas de açúcar que pudessem conduzir (Diegues JR, 1949, p. 45).

Tendo em vista que os interflúvios dessa rica rede de drenagem alagoana são tabuleiros arenosos (Figura 5), algumas vezes cobertos por vegetação de cerrado, quando o manto de cobertura é mais espesso (acima de $40 \mathrm{~cm}$ ), outras vezes cobertos por vegetação florestal, quando o manto de cobertura é mais fino (20 a $40 \mathrm{~cm}$ ), as técnicas no período colonial e monárquico não possibilitaram o seu uso pela cana-de-açúcar até os anos de 1950 (Andrade, 2005, p. 41).

Mais ao sul, a Capitania da Baía de Todos os Santos oferecia excelentes condições naturais estratégicas. Uma baía de acesso largo, com cerca de 8,5 km separando a Ilha de Itaparica, no canal do Mar Grande, e a extremidade Sudeste da Escarpa de Salvador (Ab'Sáber, 1952, p. 61). As águas eram geralmente calmas, permitindo o ancoradouro das embarcações europeias. Além disso, “a presença da falha geológica de Salvador, que modela de forma peculiar a topografia, com níveis diferenciados de altitude, permitia a visualização de toda a baía, situação privilegiada no que se referia à segurança contra os prováveis inimigos e invasores" (SEI 4 , 2003, p. 27/28).

${ }^{4}$ (Sigla). Ver na lista de referências: Superintendência de Estudos Econômicos e Sociais da Bahia. 
Figura 5. Estado de Alagoas, com indicação de possíveis áreas de ocorrência de cana-de-açúcar desde o final do século XVI.

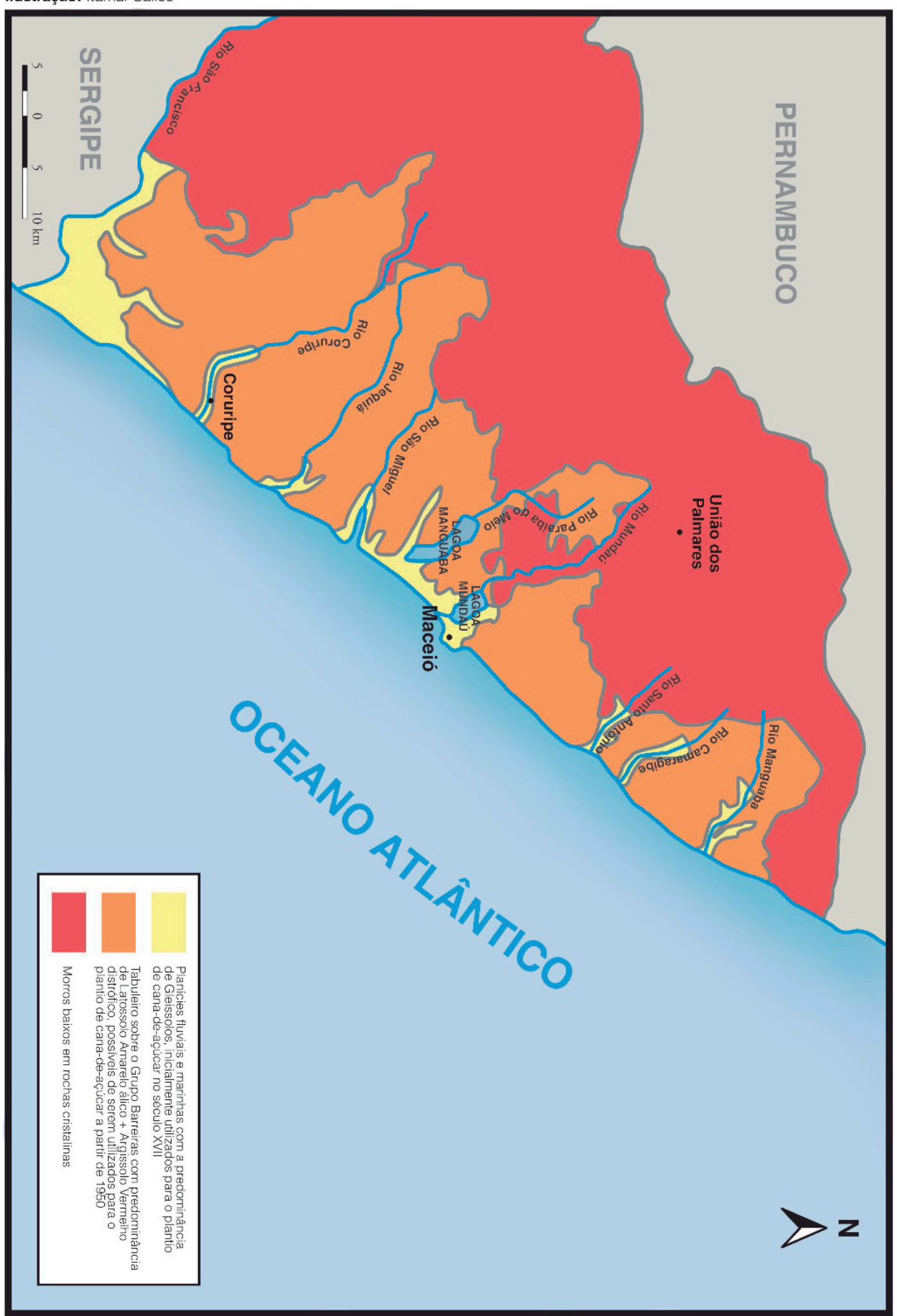

Fonte: BRASIL, 1981. Org.: dos autores, 2016. 
A apropriação dos espaços para as atividades agrícolas começou em torno da Baía de Todos os Santos, na zona denominada de Recôncavo pelos colonizadores, que incluía as terras localizadas no fundo da baía, os vales, ilhas, várzeas e baixos planaltos próximos ao mar, onde se erguia uma vegetação exuberante de floresta, hoje praticamente devastada, após mais de quatro séculos de exploração. (SEI, 2003, p. 28).

Recôncavo genericamente "significa simplesmente 'a terra ao redor de uma baía' [..]. No Brasil, porém, ela terminou se vinculando à região que circunda uma baía específica - aquela que os primeiros exploradores portugueses batizaram de baía de Todos os Santos” (Barickman, 2003, p. 36).

Contudo, nem todas as áreas no entorno da Baía de Todos os Santos eram aptas ao cultivo da cana-de-açúcar. Ao Norte e Oeste do rio Paraguaçu os solos mais arenosos não eram aptos ao seu desenvolvimento. Os melhores solos para o cultivo canavieiro eram aqueles situados na porção central e Norte do recôncavo, onde manchas de solos argilosos, tipo Vertissolos, mais conhecidos como massapês, eram encontrados.

Após a planície marinha, o recôncavo apresenta a Baixada Litorânea, que se configura pela existência de colinas rebaixadas e planaltos residuais, com altitudes inferiores a $100 \mathrm{~m}$. Com uma litologia constituída por arenitos, folhelhos, siltitos e conglomerados das Formações Ilha, Santo Amaro e São Sebastião, onde predominam os Alissolos, que possuem baixa fertilidade e altos teores de alumínio, fatores limitantes, na época, ao cultivo da cana-de-açúcar, as plantações ficavam restritas às ocorrências dos Argissolos ou dos Vertissolos, existentes sobretudo nas Vilas de Santo Amaro e São Francisco do Conde.

Assim, no século XVIII, conforme Barickman (2003), o recôncavo baiano compreendia três áreas agrícolas distintas concordantes com as características de seus solos e relevos, associados às condições climáticas da Zona da Mata. Uma vinculada aos solos arenosos, localmente denominados de "areias", na Vila de Cachoeira, ao Norte e a Oeste do rio Paraguaçu, nos quais era cultivado o fumo, comercializado 
na Europa e sobretudo na África, onde era utilizado como moeda de troca para a aquisição de escravos. Ao Sul do Recôncavo, nas Vilas de Maragogipe e Jaguaripe, predominava o cultivo da mandioca, a qual era transformada em farinha para consumo doméstico ou vendida nas feiras semanais. Ao Norte e na porção central do recôncavo, na Baixada Litorânea, onde eram encontrados os solos de textura argilosa, originados de decomposição calcária, era plantada a cana-de-açúcar. Além disso, como em todas as regiões do Brasil onde foi plantada, ela estava presente também nas planícies fluviais. Na planície do Rio Paraguaçu, por exemplo, onde está presente extensa mancha de Chernossolo, solo extremamente rico em matéria orgânica, a cana-de-açúcar também se fez dominante.

É evidente que essa divisão geográfica não era absoluta. Eram encontradas plantações de mandioca e fumo nas Vilas São Francisco do Conde e de Santo Amaro, assim como canaviais e engenhocas, em terras a Oeste e ao Sul do recôncavo (Barickman, 2003, p. 44), e mesmo nos brejos de altitude, na região sertaneja, direcionados à produção de rapadura e cachaça para consumo local. Mas as grandes extensões de cana-de-açúcar e os grandes e médios engenhos ficavam de fato localizados nas partes central e Norte do recôncavo (Barickman, 2003, p. 44), na Baixada Litorânea, logo após a planície marinha, ou nas planícies dos rios, como o Subaé e o Paraguaçu (Figura 6).

A Baía de Todos os Santos, grande braço natural do mar que adentra cerca de 40 quilômetros na costa, oferecia excelentes condições de transporte hidroviário para os engenhos e bom ancoradouro para os navios de transporte do açúcar para a Europa, o que favoreceu a capitania a tornar-se a segunda maior produtora de açúcar, com seus 36 engenhos em 1585 (Prado Jr, 1981, p. 39; Schwartz, 1988, p. 34).

Dessa forma, a produção açucareira das duas capitanias, Pernambuco e Bahia, concentrava 75\% da produção açucareira da época (Schwartz, 1988, p. 34). Ao Sul, em Porto Seguro e Ilhéus, a hostilidade indígena, os solos arenosos e o relevo em forma de morros impediram o desenvolvimento da cultura canavieira.

Embora as grandes plantações de cana tenham se localizado predominantemente na Zona da Mata para abastecer os engenhos nor- 
Figura 6. Entorno da Baía de Todos os Santos, com indicação de possíveis áreas de ocorrência de cana-de-açúcar desde o final do século XVI.

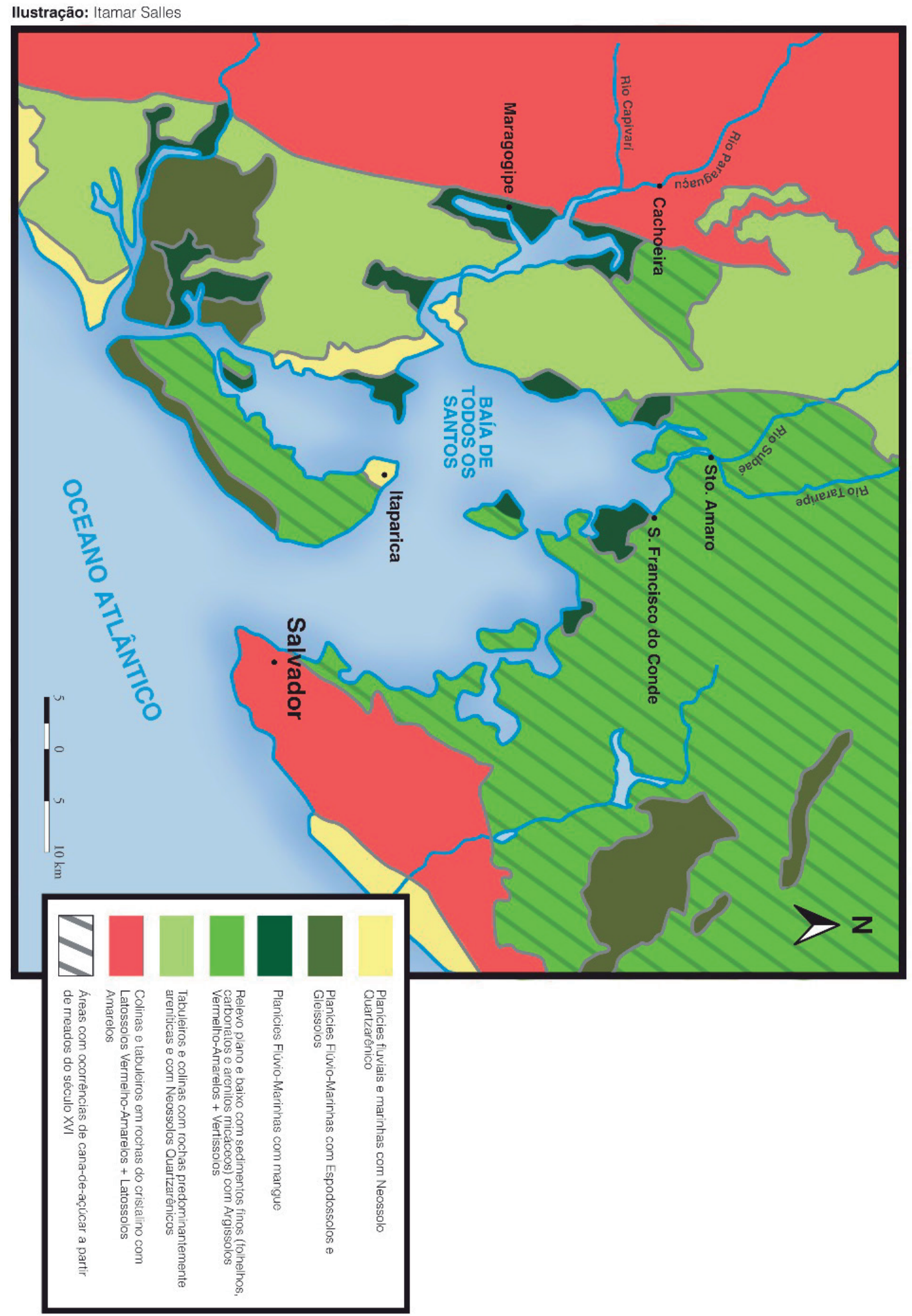

Fonte: IBGE, 1981a. Org.: dos autores, 2016. 
destinos que produziam açúcar para exportação, engenhocas que fabricavam rapadura e aguardente se proliferaram também pelas pequenas planícies fluviais mais no interior, pelo agreste nordestino.

\subsection{A expansão da cana-de-açúcar na Depressão Periférica Paulista}

A partir de 1568, a produção açucareira na Ilha de são Vicente entrou em crise, não conseguindo concorrer com a produção nordestina em franca expansão, devido à pequena extensão de solos adequados à cultura canavieira que impediam a expansão dos canaviais, bem como à distância da Corte portuguesa, bem maior se comparada com Pernambuco e com a Bahia (Petrone, 1964).

O fracasso dos objetivos iniciais da produção açucareira em São Vicente levou à colonização do litoral norte paulista e ao desenvolvimento de outras atividades com menor rentabilidade, tal como a caça ao índio na área do planalto paulista.

De fato, desde 1580 , a produção açucareira colonial começou a dar sinais de dificuldades devido à Guerra dos 80 Anos (1568-1648) para a independência das províncias do Norte dos Países Baixos da Coroa espanhola. Os holandeses, que praticamente controlavam todo o comércio ultramarino europeu de açúcar e de escravos, sofreram o bloqueio da Espanha, o que comprometeu seu papel comercial sobre a distribuição do açúcar na Europa e afetou a cooperação entre os comerciantes portugueses e flamengos.

Diante dessa dificuldade, em 1621, os holandeses fundaram a Companhia das Índias Ocidentais, cujo maior objetivo foi o rompimento do bloqueio espanhol e a retomada do comércio do açúcar no Nordeste brasileiro, o que se efetivou com a invasão e ocupação, primeiramente de Salvador e, posteriormente, de Pernambuco.

A chegada do conde de Nassau ao Brasil, em 1637, promoveu a ampliação da área subjugada pelos holandeses e um período de grande recuperação da agromanufatura açucareira pernambucana, que havia sido prejudicada pelo período de lutas contra os holandeses. A concessão de créditos, a venda dos engenhos conquistados em hasta pública a holandeses, luso-brasileiros e judeus portugueses de Amsterdã, bem 
como o fornecimento de mão-de-obra, alavancaram o desenvolvimento do setor açucareiro (Furtado, 1969; Mello, 2012, p.36).

No entanto, o fim do domínio espanhol sobre Portugal, em 1640, e a substituição de Nassau por uma nova administração, que passou a exigir a liquidação das dívidas dos senhores de engenho inadimplentes, propiciou a instauração de movimentos de insurreição à dominação holandesa, expulsa após a segunda Guerra de Guararapes, em 1654.

Nos 24 anos de domínio de parte do território produtor açucareiro brasileiro, os holandeses adquiriram o know-how sobre a técnica e a organização da indústria açucareira, as quais foram a base para a implantação e para o desenvolvimento do núcleo produtor de açúcar nas colônias caribenhas. A utilização de equipamentos novos, que melhoraram os processos de fabricação do açúcar e aumentaram a produtividade antilhana, e a posição geográfica mais favorável, fizeram o açúcar caribenho se impor no mercado internacional, levando à perda do monopólio açucareiro brasileiro, no final do século XVII, e ao colapso do seu mercado, com os preços do produto reduzidos à metade, o que se manteve durante todo o século XVIII (Furtado, 1969; Costa, 1969, p. 169), como pode ser observado nos dados referentes às estimativas de produção açucareira das colônias na América (Tabela 1).

Tabela 1. Estimativas da produção açucareira em colônias na América no último quartel do século XVIII

\begin{tabular}{|c|c|}
\hline Colônias & Toneladas de açúcar \\
\hline Francesas (1788) & 93.045 \\
\hline Inglesas (1781-1785) & 78.045 (média anual) \\
\hline Brasil (1796) & 34.276 \\
\hline Dinamarquesas (1768) & 20.550 \\
\hline Cuba (1790) & 13.993 \\
\hline Holandesas (1785) & 8.892 \\
\hline
\end{tabular}

Fonte: Reese apud Geerligs, 1912. Org.: dos autores, 2015.

Diferentemente do Brasil, as colônias antilhanas comercializavam também uma espécie de açúcar mais grosseiro, com alto teor de melado, que servia de matéria-prima para 230 refinarias da Europa seten- 
trional, localizadas em Amsterdã e Londres. Portugal e Brasil não possuíam refinarias, sendo comercializados o açúcar "barreado" e o mascavo, ambos prontos para o consumo direto (Schwartz, 1988, p. 145).

Assim, no final do século XVII, o empobrecimento cada vez maior da colônia portuguesa sul-americana e os grandes gastos para sua manutenção, bem como a intensa concorrência no mercado europeu dos produtos tropicais oriundos do Caribe e Antilhas, levaram Portugal à intensificação pela busca por metais preciosos por todo o século XVIII (Furtado, 1969).

A perda do monopólio açucareiro e o desenvolvimento da atividade mineradora no Centro-Sul não significaram a desativação das propriedades rurais canavieiras e muito menos a letargia do setor canavieiro, que continuou produtivo, sobretudo em Pernambuco e na Bahia, apesar das flutuações de preço e de produção decorrentes das conjunturas políticas e econômicas internacionais (Schwartz, 1988).

Nesse período, o Brasil perdeu a sua importância no mercado internacional. Estimativas indicam que a produção brasileira de açúcar, que era, em 1730, de 2,5 milhões de arrobas (aproximadamente 36.700 toneladas), equivalente a um terço do açúcar produzido na América em 1776, declinou para 1,4 milhão de arrobas (aproximadamente 20.600 toneladas), suprindo menos de $10 \%$ do mercado internacional (Schwartz, 1988, p. 342-343).

O Brasil não era mais uma colônia exclusivamente açucareira, mas "O açúcar ainda predominava na colônia, e os senhores de engenho ainda detinham o poder regional” (Schwartz, 1988, p. 343). Os engenhos eram adaptados para a produção de aguardente, que servia como moeda de troca na compra de escravos africanos, o que aliás foi sempre o caso daqueles localizados no litoral norte de São Paulo; no Sul da Capitania de Tomé de Souza (RJ), como Parati e Angra dos Reis; e no Recôncavo da Guanabara, onde a produção de aguardente era dominante devido à ausência de condições para a produção de açúcar.

Na região mineradora, em províncias como Minas Gerais, vários engenhos também se instalaram, destinados à produção de aguardente, e mesmo quando havia impulsos à produção açucareira, a produção de aguardente, rapadura e mascavo para consumo local era sempre pre- 
ferida devido à concorrência dos engenhos localizados na faixa litorânea, beneficiados pela sua localização para a exportação dos produtos (Holanda, 1995, p. 290).

De fato, enquanto os grandes e médios engenhos eram instalados na faixa litorânea, a cana-de-açúcar também era cultivada em quase todo o povoado em área de Mata Atlântica, beneficiada em trapiches (engenhos movidos à tração animal ou humana) e engenhocas (pequenos engenhos), atendendo a demanda interna de açúcar mascavo e de aguardente (Dean, 1996, p. 188/189)

Apesar da cana-de-açúcar proliferar em todas as capitanias, a oposição indígena, problemas econômicos e de localização resultaram na falta de continuidade e no abandono de canaviais e engenhos, com exceção daqueles localizados nas capitanias de São Vicente, de Pernambuco e da Baía de Todos os Santos, onde obtiveram algum êxito, as duas últimas figurando, no final do século XVI, como importantes núcleos exportadores de açúcar para a Europa (Schwartz, 1988, p. 31).

Essa situação mudou, ao final do século XVIII e início do século XIX, quando mudanças conjunturais externas e internas levaram o sistema açucareiro a voltar a funcionar em plena atividade. A revolução para a independência do Haiti (1801-1805); as guerras napoleônicas, com bloqueio e contrabloqueio da Europa (1805-1814); a Revolução Francesa e os reflexos nas suas colônias produtoras de artigos tropicais; o crescimento demográfico e a urbanização causados pela Revolução Industrial, com as mudanças de hábitos alimentares na Europa e grande demanda de açúcar; e a decadência da mineração no Brasil repercutiram no mercado mundial de produtos tropicais e elevaram temporariamente o preço do açúcar (Simonsen, 2005; Petrone, 1964).

Em São Paulo, a partir de 1750, quando a busca por ouro e por indígenas para escravização não apresentavam mais interesse econômico, o açúcar passou a ser o produto mais importante da economia paulista e, na verdade, um dos fatores responsáveis pelo aumento da população e pelo acúmulo de capital que permitiram, primeiramente, o aparecimento de grandes engenhos e, posteriormente, da cafeicultura (Petrone, 1964). 
Tal processo não se deu de forma espontânea, pois devido à mineração, a agricultura comercial foi deixada em segundo plano, apenas sendo praticada de forma itinerante. Nesse contexto, a partir de 1765, medidas governamentais foram tomadas para a promoção de uma agricultura de exportação de produtos derivados da cana-de-açúcar, promovendo a expansão de canaviais e a formação de importantes núcleos produtores de açúcar e de aguardente, sobretudo no Planalto Paulista (Petrone, 1964, p. 17).

No litoral ao Sulde Santos, diferentemente da época do apogeu de São Vicente, na primeira metade do século XVI, os canaviais se reduziram, voltando-se agora para a produção sobretudo de aguardente, de pequena significância (Petrone, 1964, p. 19). Diferentemente, a produção canavieira no litoral norte paulista, sobretudo em Ubatuba e São Sebastião, que desde o século XVI tinha papel importante tanto para a produção de açúcar como de aguardente, teve expansão no século XVIII, chegando, em 1788, a contar com 39 engenhos, com a produção sendo exportada principalmente pelo porto do Rio de Janeiro, onde os preços eram mais favoráveis.

Em 1789, no entanto, uma proibição governamental ao comércio dos produtos da Província de São Paulo em outros portos, que não o de Santos, provocou grande prejuízo aos negócios açucareiros da região litorânea paulista, desestimulando os produtores a manterem-se na atividade. Os canaviais só voltaram a ser produtivos depois de nove anos, quando em 1798 ocorreu nova liberação de exportação por todos os portos da costa litorânea. Ubatuba e São Sebastião passaram a contabilizar, em 1799, 44 engenhos, com a produção de 40.143 arrobas de açúcar, 239 canadas e 11 pipas de aguardente, ultrapassando a produção de antes da proibição (Petrone, 1964).

No primeiro quartel do século XIX, a cana de açúcar continuou a ser plantada no litoral norte, em Ubatuba, São Sebastião e Ilhabela. Contudo, pouco a pouco, a produção açucareira foi desaparecendo, mantendo-se apenas a de aguardente, e a cultura canavieira, a partir da década de 1830, foi substituída pelo café, que passou a ser mais interessante economicamente (Petrone, 1964, p. 23).

Além do aparecimento de um produto com forte apelo comercial 
- o café - a pequena extensão de solos pedologicamente próprios para a produção canavieira foram fatores limitantes para a continuidade da cultura canavieira no litoral paulista, considerando-se a pequena chance do aumento da sua produção, o que na época era determinado pelas possibilidades de expansão territorial.

No Planalto Paulista, as péssimas condições de transporte pelo caminho da Serra do Mar até o litoral sempre foram grande empecilho ao comércio do açúcar, facilmente deteriorável quando submetido às intempéries. Além disso, a hidrografia orientada para o interior não podia ser utilizada para o transporte do açúcar até os portos do litoral, diferentemente do que ocorria no Nordeste, restando apenas o caminho íngreme pela Serra do Mar. Tais problemas desestimularam a expansão da cultura canavieira na região até meados do século XVIII (Petrone, 1964).

Pouco a pouco, essa situação tenderia a mudar, primeiramente, com a dinamização do comércio no Porto de Santos e, posteriormente, com o aumento da produção açucareira possibilitada pela abertura de novos canaviais pelo interior paulista. Na década de 1830, a cultura canavieira paulista atingiu o seu apogeu (Petrone, 1964) e Santos se tornou, antes de ser o porto do café, o porto do açúcar (Andrade, 1994, p. 54).

De fato, a proibição do uso de outros portos, além do de Santos, a partir de 1789, para a realização do comércio entre a Capitania e a Metrópole, favoreceu os produtores de cana-de-açúcar do Planalto Paulista, que já exportavam seus produtos por esse porto, ainda pequeno e sem grande movimento comercial, e que desde a medida governamental passou a ser mais competitivo e, portanto, vantajoso a esses produtores. Somam-se a isso as facilidades para obtenção de terras, as melhores condições de relevo, clima e solo do interior paulista e a qualidade superior do açúcar produzido, quando comparado com o da região litorânea.

Além disso, o incremento da produção açucareira estimulou o investimento em melhorias do caminho na Serra do Mar, sendo providenciado no início da década de 1790 a sua pavimentação com pedras, batizada como Calçada do Lorena, em homenagem ao seu maior 
promotor, o governador da Capitania de São Paulo, Bernardo José de Lorena (1788-1797)

Todas essas condições possibilitaram o desenvolvimento do ciclo do açúcar em São Paulo, no final do século XVIII e meados do século XIX, na área entre Sorocaba, Piracicaba, Mogi Guaçu e Jundiaí, constituindo o "Quadrilátero do Açúcar" (Petrone, 1964, p. 16). Localizado predominantemente na Depressão Periférica da borda Leste da bacia do Paraná (Depressão Periférica Paulista), as terras do Quadrilátero se caracterizavam por colinas amplas, de topos convexos e Latossolos Vermelhos distróficos (Latossolos Vermelho-Escuros férricos), Argissolos Vermelhos e Nitossolos (terra roxa), Latossolos Amarelos e Argissolos Vermelho-Amarelos (Podzólicos VermelhoAmarelos) (Ross, 2006), sendo uma área fisiograficamente propícia ao plantio da cana-de-açúcar e, consequentemente, à expansão dos engenhos (Figura 8).

No Quadrilátero do Açúcar, quatro áreas de destacavam: Mogi Mirim, Itu, Piracicaba, Capivari e Campinas. Em Itu, a cana-de-açúcar teve importância fora do comum na primeira metade do século XIX, sobretudo no ano de 1854, onde a indústria açucareira paulista estava concentrada e a qual, mesmo com o surto cafeeiro, continuou a ser uma das principais produtoras de açúcar da Província, sendo superada apenas por Mogi Mirim (Petrone, 1964).

Expandindo-se a partir de Itu, canaviais foram plantados em direção a Piracicaba e Capivari. Desde o início, percebeu-se a fertilidade dos solos derivados do basalto e diabásio (Latossolos Vermelho férrico e Nitossolos) de Piracicaba para o plantio da cana-de-açúcar, cuja produtividade excedeu rapidamente a de Itu, e onde, até 1854, o cultivo da cana seguiu progressão. Do mesmo modo, em Capivari, em 1836, a produção já era de 52.193 arrobas de açúcar e 490 canadas de aguardente, produzidos em 52 engenhos, expandindo-se os canaviais até 1854, até a produção de 100 mil arrobas em 70 fazendas, não sendo afetados, portanto, pela penetração do café (Petrone, 1964).

O mesmo não aconteceu em Campinas, antigo pouso de tropeiros, que teve seu povoamento efetivo graças à fabricação do açúcar e ao cultivo da cana nos mesmos tipos de solos de Piracicaba e Capivari 
Figura 8. Estado de São Paulo, com indicação de possíveis áreas de ocorrência de cana-de-açúcar desde o final do século XVIII
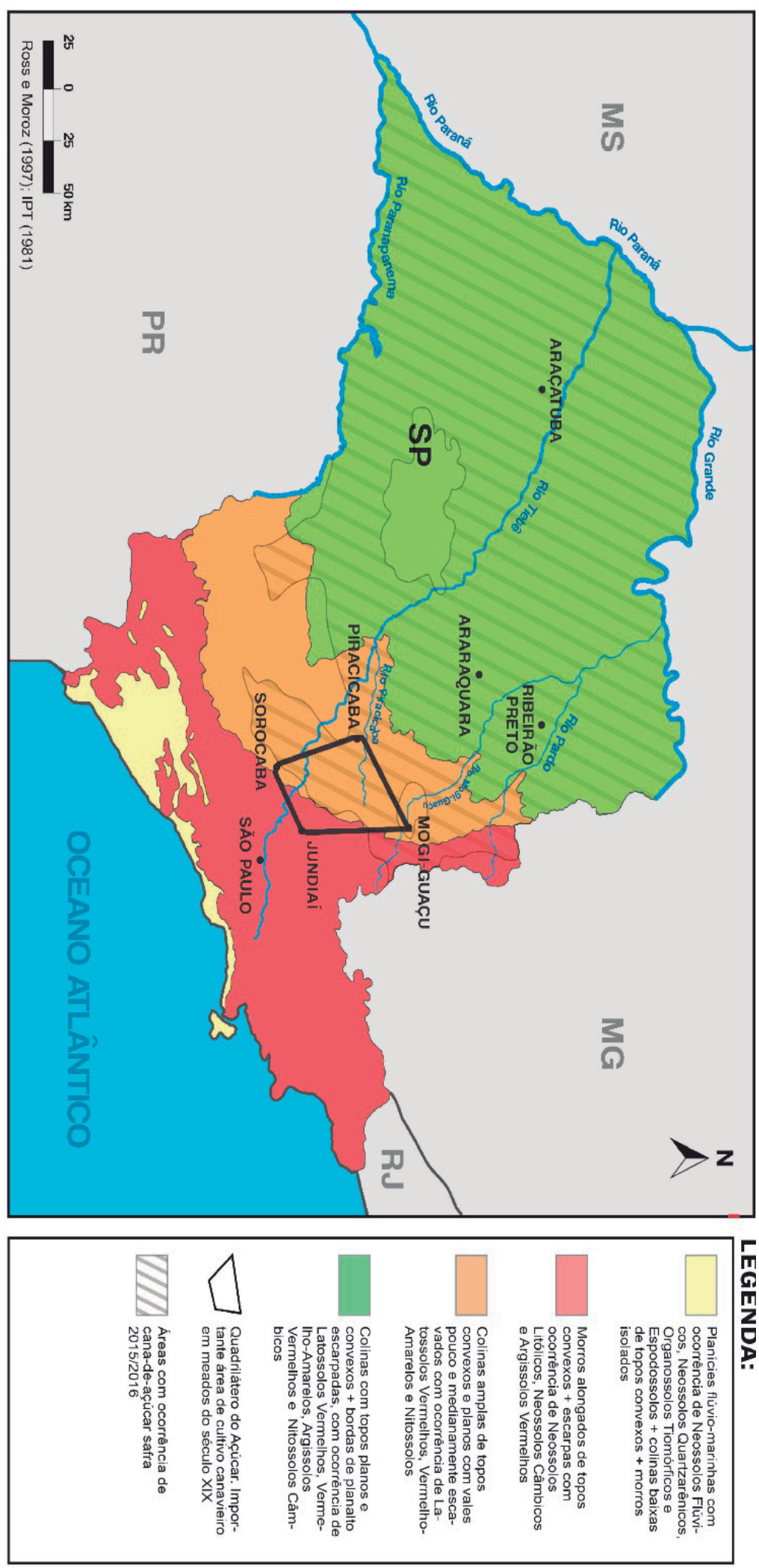

Fonte: Ross e Moroz, 1997; IPT,1981. Org.: dos autores, 2017. 
(Latossolos Vermelho férrico e Nitossolos). Desde a década de 1760, já se encontravam canaviais nessa área, mas na década de 1790 a lavoura canavieira se expandiu muito, dando importância econômica ao lugar. De início, a cultura do café encontrou obstáculo na crença de que o solo de Campinas era apto unicamente à cultura da cana. No entanto, quando se firmou a certeza de que o café daria bons resultados, a situação se modificou, o preço do açúcar caiu e a cana deixou de ser atrativa economicamente. Além do preço, a facilidade do transporte do café que não se estragava durante o transporte pelas estradas ruins foram fatores que levaram, em 1854, a produção do café, com 335.550 arrobas, a sobrepujar em mais de cinco vezes a do açúcar, com cerca de 62.290 arrobas (Petrone, 1964, p. 34).

Mais a Leste da Província, outra área importante foi Mogi Mirim, cujos solos eram muito adequados para o cultivo da cana e que em 1854 apresentou a maior quantidade de açúcar produzida em São Paulo. Outras áreas importantes dentro do Quadrilátero do Açúcar foram Jundiaí e Porto Feliz, onde também houve o interesse pelo cultivo da cana, mas que não se desenvolveu tanto como em Campinas e Piracicaba, e Sorocaba, cuja economia estava alicerçada no gado, mas onde desde cedo apareceram pequenas lavouras canavieiras, com um número grande de engenhos, mas de pequeno porte (Petrone, 1964).

Além do Quadrilátero do Açúcar, ao Sul da Província, o limite do cultivo da cana-de-açúcar era o rio Paranapanema, devido à presença de geadas e às dificuldades de transposição do leito do rio. Apesar da existência de algumas lavouras de cana, a produção de açúcar ou aguardente era insignificante, considerando-se o total produzido em São Paulo. Em direção a Goiás, as plantações de cana não assumiam também importância econômica e no Vale do Paraíba, apesar de certo destaque, a cana nunca teve a mesma relevância das áreas do Planalto, tendo o café rapidamente ocupado as áreas de morros no início do século XIX (Petrone, 1964, p. 107).

O açúcar produzido em São Paulo nunca foi de boa qualidade, em parte, por não ser bem clarificado, tendo em vista que quanto maior o número de purgas, para ficar mais fino e branco, mais se perdia em peso. Além disso, os senhores de engenho misturavam 
o açúcar de qualidade superior com o de qualidade inferior, fazendo com que resistisse menos durante o transporte e às intempéries, devido à presença de grande quantidade de matéria extrativa e sais lixiviosos que, ao menor contato com o ar úmido, o deterioravam (Petrone, 1964, p. 107).

É interessante mencionar que a exportação de açúcar paulista atingiu seu auge no biênio 1846-1847, coincidindo com a plantação de grandes cafezais, cuja frutificação se deu em 1850-1851, o que indica a inversão do capital obtido com a exportação do açúcar na cultura do café (Petrone, 1964; Canabrava, 1971). Dessa forma, na safra de 18501851, foram produzidas 344.904 arrobas de açúcar e 470.054 de café (Petrone, 1964, p. 166). A partir desse período, a produção de açúcar paulista se direcionou para o mercado interno até 1910, quando se consolidou a agroindústria canavieira moderna (Melo, 2009, p. 16).

A mudança do período colonial (1500-1822) para o período monárquico (1822-1889) não causou grandes perturbações na lavoura canavieira, tendo em vista que quando o Brasil era colônia portuguesa a sua produção econômica era orientada pelas demandas do mercado externo e pela Coroa portuguesa. Após a independência, em pleno desenvolvimento da Revolução Industrial, a divisão internacional de trabalho manteve a especialização dos países não industrializados, como o caso do Brasil, na produção de matérias-primas e de gêneros alimentícios (Canabrava, 1971, p. 85).

Do mesmo modo, ao final do século XIX, a geografia canavieira em território brasileiro pouco se alterou entre os períodos colonial e monárquico. Apesar de o Brasil ter perdido a posição de maior produtor e fornecedor de açúcar para o mercado internacional, no século XVII, as províncias de Pernambuco e da Bahia se mantiveram como as maiores produtoras de açúcar.

Em outras áreas onde a cana floresceu e apresentou importância, essa se mostrou temporária, como foi o caso de São Vicente, marco histórico da cultura canavieira, do Quadrilátero do Açúcar, que teve seu maior destaque no Império, e do litoral norte paulista. A sua descontinuidade e transitoriedade podem ser explicadas pela expansão de um produto mais rentável economicamente, como o café, mas também pe- 
las adversidades impostas pelo meio físico, fator determinante na produtividade e comercialização, sobretudo em uma época onde técnicas mais avançadas de fertilização, cultivo e transporte eram pouco desenvolvidas ou não eram conhecidas, permanecendo o cultivo canavieiro e a produção açucareira nos mesmos moldes daqueles realizados no século XVI.

\subsection{Técnicas de cultivo canavieiro e de produção}

de açúcar nos engenhos banguês

O engenho, denominado banguê, era uma unidade complexa, autossuficiente, que integrava a produção agrícola e manufatureira. Os colonizadores que estabeleceram as propriedades açucareiras e os engenhos banguês no Brasil consideravam-se a nobreza da Colônia, similarmente àquela de Portugal. Caracterizada pela posse de grandes extensões de terras e pelo controle de numerosos dependentes, formaram, ao final do século XVI, a classe dos senhores de engenho, na maior parte constituída por portugueses e por alguns espanhóis, florentinos e flamengos.

O seu domínio estendia-se a outros lavradores e a pequenos proprietários próximos de sua propriedade. O catolicismo era a base espiritual, moral e social. O culto aos santos era especialmente importante, refletindo-se na instalação dos engenhos, construídos sob a sua invocação e com muitas capelas, tradição que se perpetuou até os dias de hoje, o que não significava a observação irrestrita dos preceitos católicos, havendo muitos concubinatos e outras transgressões da fé (Schwartz, 1988, p. 239).

Os senhores de engenho geralmente moravam na fazenda com a família, administrando-a, e, no caso de fazendas menores, realizando conjuntamente grande parte do trabalho (Petrone, 1964, p. 141). A ausência da imprensa e de universidades acarretava restrições ao desenvolvimento das atividades intelectuais na colônia, as quais ficavam dependentes da metrópole portuguesa. A educação dos filhos dos senhores de engenho restringia-se a noções de leitura, escrita e aritmética, ensinadas em casa, podendo ser ampliada, no caso dos meninos, em algum colégio jesuítico. O nível universitário só era alcançado por 
aqueles que iam para Coimbra. Tal situação só se alterou no final do século XVIII, quando em algumas Capitanias, a educação pública foi instituída e o primário passou a ser ministrado em várias cidades, como foi o caso de Salvador (Schwartz, 1988, p. 239).

Inicialmente, a habitação do proprietário do engenho, as instalações para a produção de açúcar e o armazém dos produtos ficavam em uma única edificação, em duas seções separadas. Posteriormente, com a ampliação dos canaviais, o aprimoramento das técnicas de produção e o aumento da quantidade de açúcar produzido, os setores residenciais e de produção foram separados, originando as chamadas casas-grandes, sobretudo no Nordeste brasileiro (Reis, 1999, p. 69). As paisagens canavieiras passaram então a ser caracterizadas pela existência da casa-grande, da capela e da senzala, o que refletia a divisão em classes majoritárias da sociedade canavieira - o senhor de engenho e sua família, o clero e os escravos.

Apesar de alguns engenhos instalados no início da colonização serem movidos à força hidráulica, a plantação de cana-de-açúcar e a maioria dos engenhos instalados seguiam o padrão importado da Ilha da Madeira. Adaptado às condições fisiográficas das várias capitanias da nova colônia, com algumas pequenas modificações técnicas, esse modelo foi seguido até o final do século XVIII por praticamente todos os engenhos no Brasil, sistema considerado o melhor no século XVI, o que ensejou o desejo por parte de potências europeias, como Inglaterra e Holanda, de copiá-lo (Schwartz, 2008, p. 116).

$\mathrm{O}$ trabalho era dividido em dois espaços e tempos, diferentes e complementares, um no canavial e outro no engenho. Depois de adquirida a terra, seja por sesmaria, posse, herança ou compra, e certo número de escravos, o fazendeiro construía habitações toscas e iniciava o trabalho na área florestada destinada ao canavial (Schwartz, 1988; Petrone, 1964, p. 89; Holanda, 1994, p. 206). Toda a vegetação presente no terreno onde a cana seria cultivada era retirada com machados e enxadas, cuja madeira era levada para ser utilizada nas fornalhas e nos edifícios do engenho. Depois se efetuava a queima da biomassa florestal que ainda restava nos campos, estando a terra apta para ser cultivada (Schwartz, 1988, p. 102; Petrone, 1964). 
A cana era plantada, utilizando-se as mudas provenientes de plantas adultas, geralmente de primeiro corte. Algumas vezes, após a remoção da mata e a limpeza do terreno, eram plantados primeiramente milho, feijão, legumes e mandioca (Schwartz, 1988, p. 102; Petrone, 1964).

Enquanto esse trabalho de preparo do terreno era executado, o agricultor, juntamente com o carpinteiro, construía a moenda, geralmente um trabalho que demorava mais de um ano, o que coincidia com o tempo de crescimento da cana para a primeira colheita (Schwartz, 1988).

Após duas semanas do plantio, apareciam os brotos e depois de dois meses, com a cana já com aproximadamente $60 \mathrm{~cm}$, começava-se a limpeza do canavial, trabalho bastante penoso devido às folhas ásperas e afiadas, e que ocorria pelo menos três vezes em cada safra, para a retirada de ervas daninhas (Schwartz, 1988, p. 103; Petrone, 1964, p. 91).

Após catorze a dezoito meses, a cana recentemente plantada estava pronta para o primeiro corte, com o uso da foice. Era juntada em feixes e carregada até os carros de boi ou barcos, caso o canavial fosse próximo de algum curso d'água, para depois seguir para a moagem. A cana cortada produzia novos brotos que depois de um ano estavam prontos para serem cortados, iniciando-se o processo novamente, repetido por três ou quatro vezes (Schwartz, 1988, p. 104).

Dessa forma, o planejamento da colheita de um engenho era complexo, porque o corte da cana dependia da idade da planta em razão dos diferentes períodos de maturação dos canaviais, devendo haver o cuidado de organizar o plantio de modo a propiciar o amadurecimento sucessivo, possibilitando o corte em sequência e o fluxo constante de matéria-prima para o engenho (Schwartz, 1988, p. 104).

Outras questões a serem consideradas eram o estágio de maturação, pois, se ultrapassado, deixava a cana ressecada e quebradiça, não fornecendo bom açúcar, e a necessidade de moagem no prazo máximo de dois dias após a colheita, caso contrário o líquido azedava ou secava (Schwartz, 1988, p. 104).

Devido aos métodos primitivos de cultivo, sem uso de adubo ou fertilizantes, a terra esgotava-se rapidamente, havendo a necessidade 
de, após o terceiro ou quarto corte, o canavial ser renovado ou a terra deixada em pousio por 6 a 8 anos, para recuperar a sua fertilidade (Petrone, 1964).

A falta de uso de fertilizantes e de outras práticas de conservação do solo, com o passar do tempo, provocava a redução de seus nutrientes e a diminuição dos ciclos de rebrota, culminado às vezes em uma única colheita. Após 20 ou 30 anos de uso, a terra não se prestava mais para a cultura canavieira, sendo abandonada e buscando-se outro terreno para o plantio de mantimentos e da cana, quando uma nova área de mata era derrubada para o reinício de todo o ciclo (Petrone, 1964; Dean, 1996, p. 191).

Após a cana chegar ao engenho, era depositada em um pátio, sendo encaminhada para a moenda, onde o caldo, que constitui $90 \%$ do seu peso, era extraído por meio de prensagem em grandes rolos de madeira de lei, cobertos por arcos ou placas de ferro (Figura 9) (Eisenberg, 1977, p. 61; Schwartz, 1988, p. 104). O bagaço não aproveitado era recolhido por quatro ou seis escravos que diariamente o lançavam no campo, para queimá-lo ao final da safra (Ferlini, 1984). As moendas eram movidas por tração humana, animal ou por força hidráulica. Em virtude de os engenhos reais - movidos por roda d'água - terem uma instalação mais difícil, pois requeriam encanamento até o engenho, eram preferidos os de tração animal, sobretudo nas engenhocas destinadas à fabricação de aguardente e rapadura.

O caldo extraído era recolhido em uma gamela de madeira, de onde corria por uma bica até um recipiente, sendo encaminhado para clarificação na casa das caldeiras. Utilizando-se de quatro a sete caldeiras, geralmente de cobre, mais leves e melhores condutoras de calor, cada uma com sua fornalha, dispostas linearmente, o caldo era aquecido em várias temperaturas, promovendo a evaporação da água, cerca de $70 \%$ a $80 \%$ do caldo.

Na primeira caldeira, a uma temperatura inferior à de fervura, as impurezas que afloravam eram removidas com escumadeiras e o líquido restante colocado em uma segunda caldeira. Nela, eram acrescentadas cinzas, cal, ossos queimados e sangue de animais, e o líquido aquecido a uma temperatura maior. As impurezas flutuavam e 
a escuma formada nessa etapa era retirada e usada para fazer garapa para os escravos. O líquido passava então para outros paróis para ser aquecido novamente e coado, sendo então encaminhado para tachos, onde era cozido em temperatura alta, cujas escumas eram guardadas e utilizadas para produzir açúcares de qualidade inferior (Schwartz, 1988, p. 111/112; Eisenberg, 1977, p. 62)

Figura 9. Moendas de rolo utilizadas nos engenhos banguês até o início do século XVII. Os rolos eram de madeira e não permitiam a alimentação pelos dois lados, o que exigia a movimentação do escravo para repassar a cana espremida e obter maior quantidade de caldo.

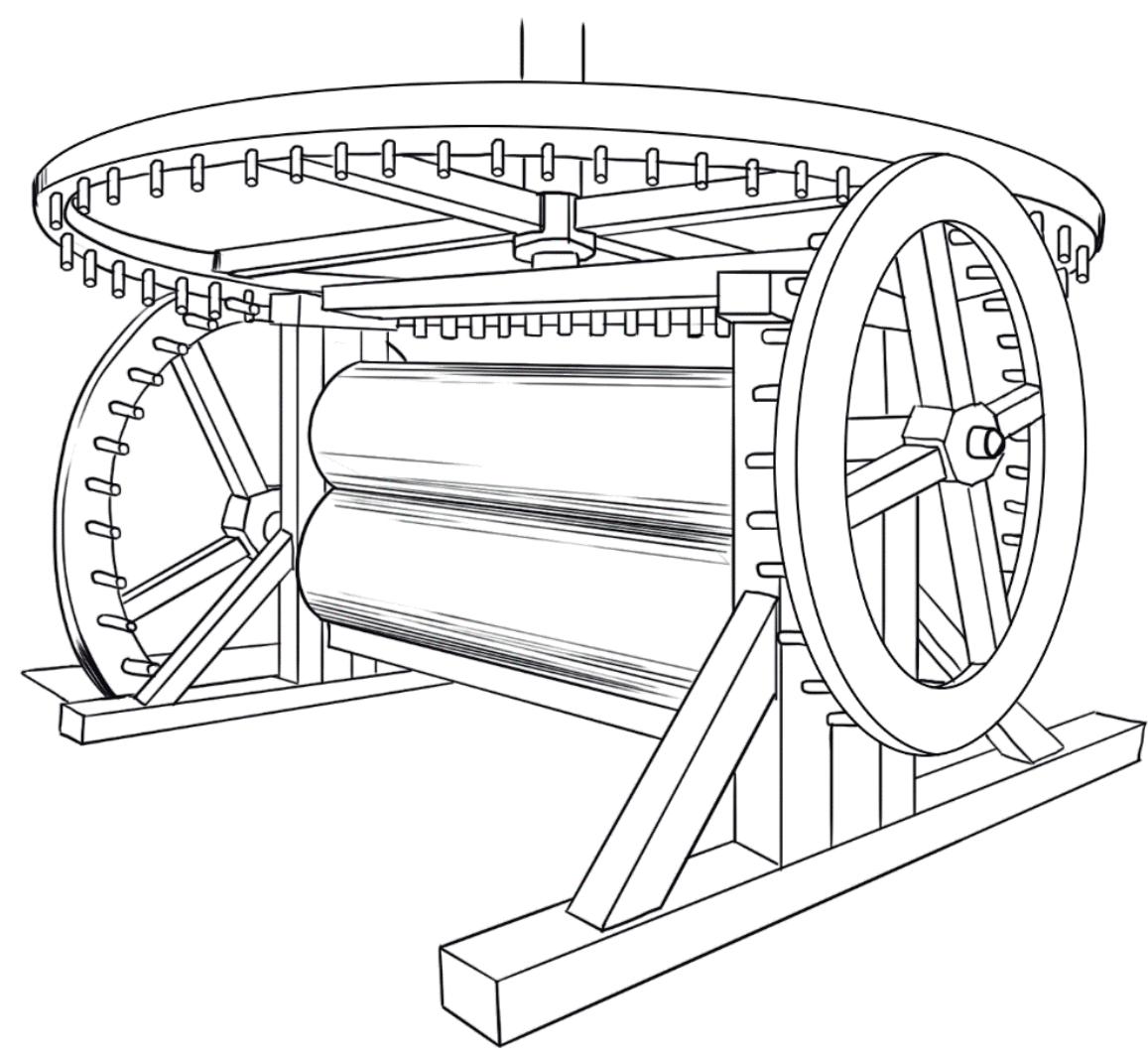

Fonte: Fernandes, 1971, p. 27. Desenho: Max Andrade, 2015.

$\mathrm{Na}$ última etapa, o líquido era colocado em um grande tacho, mexido com uma espátula de madeira, sendo erguido bem alto para verificação de sua consistência. Pela cor, odor e textura, o tacheiro e o mestre de açúcar sabiam se havia alcançado o ponto para o líquido ser despejado em formas de barro, com formato cônico, que tinham no seu fundo um buraco, tampado com folha de bananeira. As formas cheias 
eram levadas à casa de purgar, onde eram colocadas em andaimes e os buracos abertos após 24 horas, quando o líquido já estava mais condensado para a primeira purga e o escoamento do melaço (Petrone, 1964, p. 106; Schwartz, 1988, p. 111/112).

Após 15 dias, a parte superior era comprimida e coberta com argila saturada com água. Conforme a água percolava, filtrava a massa disposta na forma, carregando impurezas e o melado, o qual era coletado em uma bica que ficava sob as formas que dava para um tanque. Para a produção de um açúcar de melhor qualidade, a filtragem com argila devia ser processada pelo menos duas vezes. O melado era utilizado para a fabricação de cachaça ou encaminhado de volta para uma nova filtragem, a qual podia ser repetida até seis vezes, dependendo da qualidade do açúcar (Petrone, 1964, p. 107; Schwartz, 1988, p. 111/112).

Após quatro a seis semanas na casa de purgar, o açúcar estava pronto para ser retirado da forma, o que devia ser feito em dia ensolarado. As formas eram viradas de cabeça para baixo e com uma faca ou machadinha, a parte inferior do chamado "pão de açúcar" era removida. O açúcar que se formava na parte superior, branco, era separado da parte do meio (açúcar mascavo), sendo então quebrado em torrões menores, deixados para secar completamente. Após a remoção completa da umidade, o açúcar estava pronto para ser pesado e expedido para a Europa em grandes caixas de madeira (Schwartz, 1988, p. 111/112). Ao produtor o pagamento era feito em dinheiro ou artigos de luxo, tais como tecidos finos, vinhos, farinha de trigo (Simonsen, 2005, p. 101; Abreu, 1988, p. 40).

Todo esse processo na casa das caldeiras dependia do calor proveniente das fornalhas, as quais ficavam, nos primeiros engenhos, sob as caldeiras e os tachos. Posteriormente, com o avanço das técnicas construtivas de engenhos, ficavam numa espécie de porão, embaixo da casa das caldeiras, alimentadas com lenha, do lado de fora do edifício (Schwartz, 1988, p. 110). As cinzas das fornalhas eram utilizadas no processo de clarificação do líquido da cana (Schwartz, 1988, p. 110), sendo um prenúncio do reúso de resíduos sólidos, empregado depois nas usinas sucroalcooleiras ao final do século XX. 
O trabalho no engenho era ininterrupto, sendo as atividades relacionadas ao canavial realizadas durante o dia e as atividades da moenda à noite, a qual ficava em funcionamento por 18 a 20 horas, parando apenas para sua limpeza. Como não havia um número suficiente de escravos, aqueles que trabalhavam nos canaviais muitas vezes também tinham que trabalhar na moenda, principalmente na época da safra (Schwartz, 1988, p. 97).

Apesar do ritmo de trabalho intenso, as paralisações eram constantes por causa da quebra de rodas, moendas, por falta de lenha e, principalmente, pelos domingos e dias santos, responsáveis por mais de $75 \%$ dos dias parados. Tomando-se como exemplo os engenhos baianos, em meados do século XVII, o total de dias de moagem ficaria entre 200 e 220 dias (Schwartz, 1988, p. 99).

Fica evidente que o processo de cultivo e beneficiamento da cana demandava uma grande quantidade de técnicos no fabrico do açúcar, especialistas em construção de moendas e rodas d'água, mestres de açúcar que dirigiam as operações no canavial e no engenho e, também, de artesãos, tais como pedreiros, calafates, tanoeiros, ferreiros, serradores, carreteiros, carpinteiros (Schwartz, 1988, p. 37), geralmente trabalhadores livres europeus. Aliás, a carpintaria era um dos ofícios mais importantes no engenho, pois o carpinteiro era o responsável pela construção do engenho e de todos os outros objetos necessários ao beneficiamento da cana, tais como a bolandeira e o rodete, e pela extração, preparo e condução das madeiras até o engenho (Petrone, 1964, p. 106).

Da mesma forma, a fazenda canavieira exigia um trabalho duro, com a necessidade de muitos trabalhadores para os canaviais, para o beneficiamento da cana e para o transporte dos produtos do engenho e da lenha que alimentava as suas fornalhas, bem como para a produção e o preparo dos alimentos. Apenas o colono europeu não era suficiente, havendo a necessidade, no princípio da colonização, do uso extensivo do trabalho indígena, cuja escravização, apesar de ser uma etapa transitória para o trabalho negro, foi importante no desenvolvimento da indústria canavieira durante quase todo o século XVI.

O período entre 1540 e 1570 marcou o apogeu da escravidão in- 
dígena nos engenhos brasileiros, quando foi legalmente proibida pela Coroa portuguesa. Contudo, mesmo após a proibição, outras estratégias de sujeição, além da escravização, passaram a ser utilizadas para assegurar o trabalho indígena, tais como a aculturação e a destribalização, realizadas pelos jesuítas e por outras ordens religiosas, e a integração dos indígenas individualmente como trabalhadores assalariados, utilizada tanto por religiosos como por colonos. Além disso, uma lei, de 1570, permitiu a aquisição de cativos que estavam nas mãos de outras tribos indígenas inimigas, criando um precedente largamente utilizado mesmo quando não justificado (Schwartz, 1988).

O contato intensivo com os europeus nos engenhos e nas aldeias tornou os índios vulneráveis às doenças europeias, como a varíola, cuja epidemia atingiu seu auge em 1562, com a morte de cerca de 30 mil índios sob poder português, e o sarampo, que, em 1563, matou outros tantos milhares. Os efeitos dessas epidemias foram avassaladores para as colônias açucareiras, tendo em vista a necessidade dessa mão de obra para a produção do açúcar, mas também pela dependência do trabalho indígena para a obtenção dos gêneros alimentícios nativos, os quais passaram a faltar, causando privações para os portugueses e mais mortes para os índios, de inanição (Schwartz, 1988).

A rejeição contumaz dos aborígenes às políticas europeias de controle do seu trabalho, via resistência armada, associada à crescente oposição da Coroa à escravização, aos problemas causados pelas duas epidemias e à produtividade bem maior do escravo africano quando comparada à do indígena, levaram os portugueses, a partir de 1570, a iniciar a importação de africanos (Schwartz, 1988).

A transição da mão-de-obra indígena para a africana ocorreu gradualmente, nas duas primeiras décadas do século XVII, quando os altos preços internacionais do açúcar e a trégua dos doze anos entre Espanha e Holanda (1609-1621) causaram o incremento da indústria açucareira e consequentemente o acúmulo de capital necessário para a compra de cativos africanos pelos senhores de engenho, sobretudo do Nordeste. A mudança na composição da mão de obra utilizada na indústria açucareira pode ser verificada, tomando-se como exemplo o Engenho de Sergipe, na Bahia. Em 1572, havia 280 escravos no 
engenho, dos quais 20 (7\%) eram africanos; em 1591, havia 103 escravos, 38 (37\%) africanos; e, em 1638, 81 escravos, todos africanos (Schwartz, 1988).

Familiarizados com o ferro, o gado e outras atividades úteis à cultura canavieira, os africanos eram apreciados pelos europeus como mão de obra para o plantio e beneficiamento da cana. Além disso, apesar de sofrerem inicialmente com as condições ambientais brasileiras, logo depois de sua ambientação, eram menos suscetíveis às doenças europeias, sendo, portanto, um investimento mais seguro do que os indígenas (Schwartz, 1988).

Assim, o trabalho escravo africano predominou na cultura da cana-de-açúcar até meados do século XIX, quando o tráfico interno de escravos das culturas canavieiras para as lavouras cafeeiras, as políticas de abolição e o consequente preço alto dos escravos pressionaram os fazendeiros a renunciarem ao sistema escravista, mesmo antes da sua total abolição. O tráfico interprovincial contribuiu para isso, tendo em vista que para cobrir suas dívidas os plantadores de cana vendiam seus escravos, pagando uma taxa de saída de 100 mil-réis por escravo, em 1852, e de 200 mil-réis após 1859, o que acabou levando a um grande número de escravos contrabandeados para as plantações de café do Sudeste (Eisenberg, 1977, p. 174/175).

O declínio do número de escravos acelerou-se a partir da extinção do tráfico negreiro, com a proclamação da Lei Eusébio de Queiroz (1850), inflacionando o valor dos escravos africanos em mais de 50\% na década de 1860 , se comparado com os valores da década anterior. A reprodução natural das escravas não era suficiente para atender a demanda de escravos nos canaviais e engenhos. Os fazendeiros sempre preferiam a compra de trabalhadores mais fortes e do sexo masculino, desequilibrando o número de escravas presentes nas fazendas canavieiras. Além disso, a fertilidade das escravas era menor, se comparada com a das mulheres livres, e havia um alto índice de mortalidade infantil entre os nascidos. Em Pernambuco, por exemplo, entre 1871 e 1887, das 36.807 crianças nascidas de mães escravas e registradas, 8.545 morreram, o que representa uma taxa anual de mortalidade de 232 por mil para a faixa etária de o a 16 anos (Eisenberg, 1977, p. 172). 
Apesar da duvidosa efetividade, duas outras leis auxiliaram na limitação da escravatura: a Lei do Ventre Livre, que em 1871 libertou as crianças que nasciam de mães escravas, e a Lei dos Sexagenários, que em 1885 libertou todos os escravos com mais de 60 anos. Em 1888, foi aprovada a Lei Áurea, que aboliu a escravatura, libertando os últimos escravos do Império, não obstante a transição da mão de obra escrava para o trabalhador livre já ter se iniciado antes (Eisenberg, 1977, p. 177-179).

A mão de obra foi um fator de produção importantíssimo, assim como a disponibilidade de terras, para a expansão do setor canavieiro até o final do século XVIII, já que praticamente nenhum aperfeiçoamento se deu no processo de fabricação de açúcar do canavial até a sua expedição, desde o século XVI, conforme comentado anteriormente. O único avanço técnico importante realizado durante esse período, ainda no início do século XVII, foi a introdução da moenda de três tambores menores verticais (Figura 10), o que permitiu maior ritmo de moagem da cana e uso de menor número de animais como força motriz para sua impulsão, além do custo menor para sua construção, se comparado com o sistema anterior de moagem, com dois tambores horizontais justapostos (Schwartz, 1988).

$\mathrm{Na}$ área de plantio, o único avanço a ser destacado foi a adoção de novas variedades de cana, mais produtivas. No Brasil, eram plantadas duas espécies de cana: a "crioula", trazida da Ilha da Madeira, cultivada desde as origens do ciclo açucareiro, e a "caiana”, originária do Taiti, introduzida no Pará, entre os anos de 1790 e 1803, expandindo-se a partir de 1809 até São Paulo e outras áreas canavieiras. A cana caiana tinha o crescimento mais rápido do que a crioula, maturando em apenas nove meses. O caule fibroso, mais resistente ao vento, era bom para o uso nas fornalhas como combustível e produzia mais caldo, favorecendo a cristalização regular com menos mel e a produção de açúcar mais alvo. Sua produtividade era cerca de quatro vezes maior do que a da crioula (Petrone, 1965, p. 90; Schwartz, 1988, p. 349-350; Canabrava, 1971, p. 102; Eisenberg, 1977). 
Figura 10. Moenda de três rolos verticais introduzida no início do século XVII, o que permitiu maior produtividade de caldo espremido.

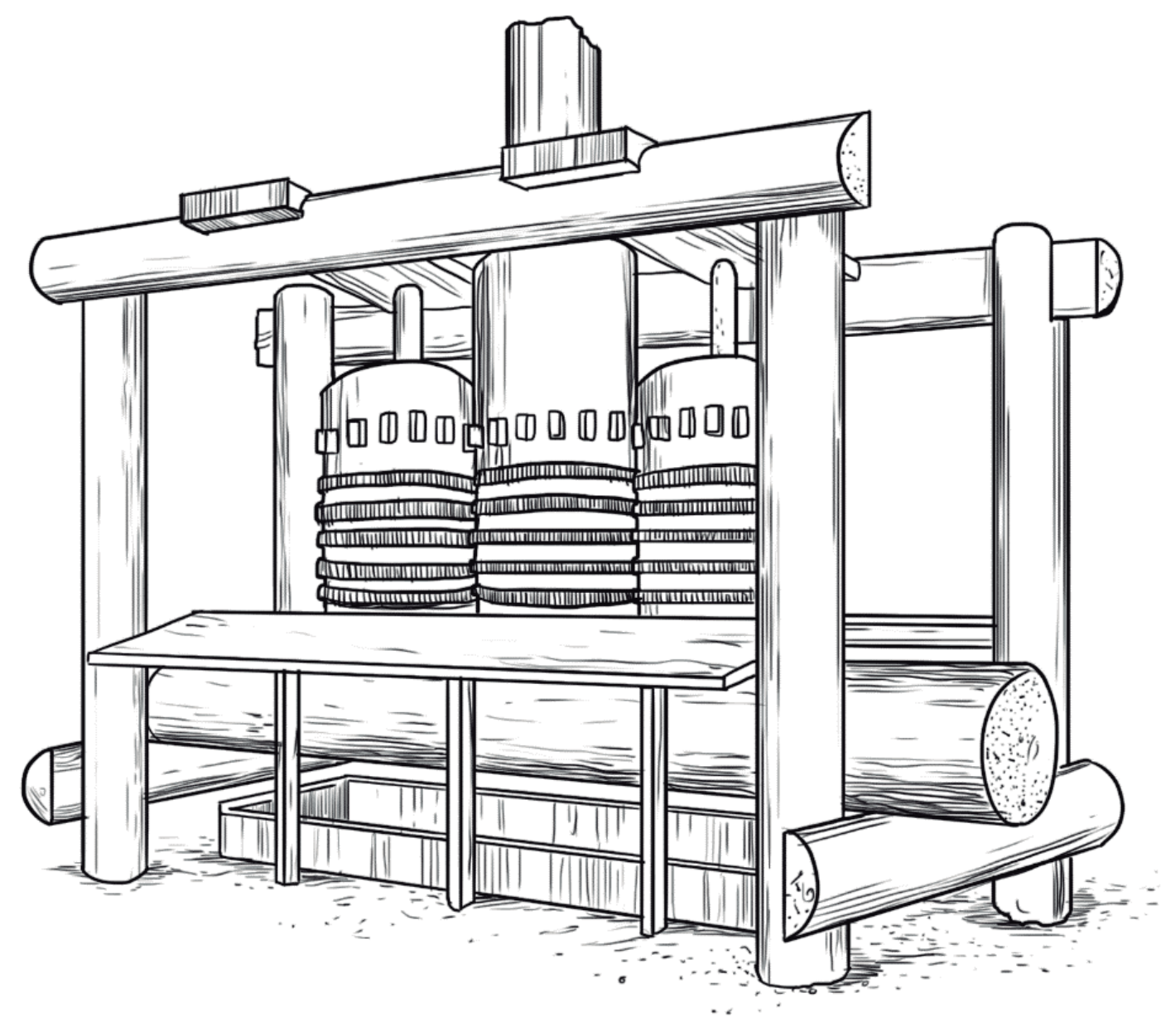

Fonte: Fernandes, 1971, p. 29. Desenho: Max Andrade, 2015.

O caule mais fibroso, entretanto, dificultava a moagem em tambores de madeira. Além disso, após algum tempo de plantio, a cana caiana mostrou-se mais suscetível à gomose, doença bacteriana causada pela Xanthomonas axonopodis pv. Vasculoruma, observada em relatos desde 1838 em canaviais desde o Sudeste até o Nordeste do Brasil. A gomose produz uma substância amarelada, a goma, expelida no colmo das canas doentes quando cortado transversalmente, provocando sérios problemas no processamento da cana e a morte precoce das plantas infectadas (Almeida, 2003, p. 18). Isso levou ao retorno do cultivo da cana crioula ou à renovação dos canaviais com outras variedades que passaram a ser difundidas a partir da década de 1850, por 
iniciativa oficial e particular, como a Selangor ou Penag, vindas de Java, e de variedades híbridas nacionais, como a cristalina (Canabrava, 1971, p. 103). As novas variedades de cana foram ajustadas às antigas técnicas de plantio, ou seja, às três limpas anuais, com o uso da enxada, da foice e da queimada (Canabrava, 1971, p. 103).

$\mathrm{O}$ arado, apesar de amplamente utilizado pelos portugueses há séculos, no Brasil foi esquecido. É necessário lembrar que grande parte dos colonizadores portugueses que vieram para o Brasil era oriunda do Minho, Sul do Douro e Estremadura, onde o equipamento tradicional utilizado na agricultura era o arado do tipo quadrangular, extremamente pesado, puxado por dez ou mais bois, que fazia sulcos profundos no solo, inadequado para os ambientes tropicais, onde tal operação soterrava a fina camada húmica superficial. Outra questão é que após o corte das árvores da Mata Atlântica, os tocos e as raízes remanescentes eram um empecilho para o uso desse tipo de arado (Holanda, 1994, p. 206207; Holanda, 1995, p. 50).

Apesar de as primeiras máquinas a vapor serem instaladas nos engenhos da Bahia em 1815; de Pernambuco em 1817; e de Campos, no Rio de Janeiro, em 1827, o uso dessa força motriz demorou a ser amplamente utilizada, dando-se preferência à tração animal. Em 1857, em Pernambuco, do total de 1.106 engenhos, apenas 18 eram a vapor, 346 movidos por força hidráulica e o restante por tração animal. $\mathrm{O}$ alto preço do maquinário necessário para a produção de vapor, importado da Inglaterra, aliado aos problemas técnicos que envolviam a sua manutenção, adiou a sua disseminação, ainda que a produtividade da moenda à tração animal fosse menor (25 a 30 tarefas $^{5}$ de cana por dia, enquanto os de água produziam de 30 a 40) e a conservação dos animais na entressafra, dispendiosa (Costa, 1969, p. 170; Canabrava, 1971, p. 105).

Concomitantemente ao vapor, outros elementos da tecnologia açucareira foram sendo desenvolvidos. O centrifugador, inventado em 1837, revolucionou a técnica de purgar o açúcar. Essa tecnologia possibilitava a separação do cristal de açúcar do mel por movimento mecâ-

${ }_{5}$ Tarefa - volume de cana moída por dia (MELLO, 2012, p. 198). Na Bahia, também era unidade de terra, com cerca de 4.352 metros quadrados (SCHWARTZ, 1988, p. 103). 
nico, de forma rápida, limpa e segura, obtendo-se um açúcar mais seco, possível de ser transportado em sacos de tecido, não necessitando mais de caixas de madeira. Em Pernambuco, foi fabricada uma de madeira, nos primeiros anos da década de 1850, mas a primeira centrífuga da província foi importada apenas em 1872; outras, em Campos, em 1856, e em São Paulo, em 1859 (Canabrava, 1971, p. 106).

Outro avanço foi a caldeira a vácuo, em substituição à caldeira de cobre, instalada na Bahia, no final da década de 1840, e em Pernambuco e em Campos na década de 1870 (Canabrava, 1971, p. 106). Semelhante a uma panela de pressão, o vácuo ou a condensação de vapor era produzido no interior do equipamento, o que provocava a fervura do caldo de cana em temperatura mais baixa e impedia a queima do açúcar (Gama, 1979, p. 213).

Todos esses aperfeiçoamentos tecnológicos possibilitaram o uso de bagaço da cana como combustível, permitindo a reativação de engenhos paralisados por falta de lenha. A introdução da moenda de quatro tambores, de ferro, substituindo a antiga moenda de três cilindros, de madeira, viabilizou o esmagamento da cana caiana e a máxima extração de líquido, adequado ao cozimento a vapor e à produção de um resíduo mais seco, apropriado ao uso como combustível nos engenhos (Canabrava, 1971, p. 106).

Em 1878, entretanto, ainda predominava, por exemplo, na Província da Bahia, a produção de açúcar mascavo e, com exceção de dois ou três engenhos, o emprego da lenha nas fornalhas. No mesmo ano, em Pernambuco, apenas três engenhos eram a vapor, o que indica o predomínio do uso das antigas técnicas no setor açucareiro (Canabrava, 1971, p. 107).

Os avanços tecnológicos, portanto, na maior parte das vezes, ocorriam isoladamente, em um ou outro engenho, e depois se perdiam por causa das dificuldades de instalação e de manutenção das novas tecnologias, do desconhecimento em relação aos seus resultados práticos, ressurgindo depois, em outro contexto técnico e econômico mais apropriado. Faltavam unidade, incremento na proliferação das novas técnicas nos engenhos, estabilidade dos progressos tecnológicos conquistados e capital. Havia ainda a necessidade da desconstrução de ro- 
tinas tradicionais, de antigos conceitos arraigados na cultura açucareira, herdados desde o século XVI.

Melhoramentos tecnológicos exigiam despesas que variavam de 50 a 70 contos, possíveis de serem pagos apenas pelos grandes engenhos. Mas nove décimos dos engenhos eram pequenos e encontravam-se em situação crítica, não conseguindo quitar nem sequer seus impostos em dinheiro, entregando para tal a mão de obra escrava, o que agravava ainda mais a situação. A tecnologia obsoleta, a falta de mão de obra e de lenha levavam esses engenhos ao "fogo morto" (Costa, 1969, p. 171).

Nesse contexto, a visão geral de estadistas e senhores de engenho, na década de 1870 , era de que a modernização do setor açucareiro só poderia ocorrer com o apoio governamental para a obtenção do capital técnico e financeiro necessário. Em 1875, a promulgação das leis de 29 de setembro e 6 de novembro sobre os engenhos centrais (Canabrava, 1971, p. 108) iria ao encontro dessa expectativa, iniciando a partir de então uma nova fase, marcada pela substituição dos engenhos banguês pelas usinas de açúcar, a ser tratada no próximo capítulo.

Mas, anterior a isso, é importante assinalar como a geografia canavieira, até o final do século XIX, se acomodou em parte do território brasileiro, sobretudo na sua faixa litorânea, impactando sociedades originárias6 e o patrimônio natural.

\subsection{Impactos socioambientais da agromanufatura açucareira}

Um dos efeitos que mais se distingue na observação de qualquer atividade humana sobre a paisagem é a retirada da cobertura vegetal. No caso do plantio da cana-de-açúcar, a Floresta Pluvial Atlântica, ou Mata Atlântica, foi a primeira a ser afetada.

A Floresta Tropical Atlântica "corresponde à extensa faixa de terras que se alonga na direção Norte-Sul, desde o litoral oriental da

\footnotetext{
6 Porto-Gonçalves diferencia sociedades originárias das sociedades tradicionais, apontando que a expressão tradicional se vincula a uma hierarquização estabelecida na perspectiva eurocêntrica do tradicional ao moderno, ao passo que o vocábulo "originária" negaria esse ponto de vista, destacando os seus valores próprios (PORTO-GONÇALVES, 2012, p. 25).
} 
Região Nordeste até o Norte-Nordeste do Estado do Rio Grande do Sul" (Ross, 2006, p. 94), abrangendo originalmente cerca de 1 milhão de quilômetros quadrados (Ab’Sáber, 2003, p. 45; Dean, 1996, p. 25).

Fazendo-se um transecto direção Leste-Oeste, verifica-se de maneira geral que, ao longo do litoral brasileiro, depois das dunas arenosas, estende-se a vegetação de Jundu sobre os solos pobres em nutrientes dos cordões arenosos (restingas), que pode interiorizar-se por cerca de trinta quilômetros (Dean, 1996, p. 26). Para além das restingas,

no Piemonte, fica uma formação majestosa de árvores latifoliadas, perenes e pluviais, de trinta a 35 metros de altura, com espécimes esparsos que chegam a quarenta metros, sustentados por troncos com doze metros ou mais de circunferência. Abaixo desse vertiginoso dossel, distingue-se três ou quatro outros sub-bosques ou patamares, "florestas que se sobrepõem a florestas", consistindo as mais baixas de árvores latifoliadas, palmeira, bambus e samambaias gigantes, que toleram luz moderada. Epífitas e parasitas engrinaldam os galhos, gavinhas escalam seus troncos e lianas acortinam os espaços intermediários (Dean, 1996, p. 26).

Os solos, sobre os quais essa floresta se desenvolveu, são de origem granítica, basáltica e gnáissica antiga, muito intemperizados, profundos e argilosos, com pouca capacidade de reter água e nutrientes. A serrapilheira gerada pela floresta é, portanto, de fundamental importância, pois sob a sombra da floresta é mineralizada por cupins, fungos e bactérias, formando o substrato orgânico necessário para a manutenção da própria floresta (Dean, 1996, p. 27). "O resultado foi uma biomassa vegetal que, em alguns lugares, pode ter chegado a seiscentas toneladas por hectare e a uma capacidade de gerar talvez cinquenta toneladas de biomassa por ano" (Dean, 1996, p. 33).

É certo que a Mata Atlântica já havia passado por alterações provocadas pelos primeiros agrupamentos humanos, sobretudo coletores e caçadores, que se estabeleceram preferencialmente perto dos cursos d'água ao longo dos 11 mil anos que precederam a chegada dos europeus ao Novo Mundo. 
Mesmo antes da chegada de Martim Afonso, em São Vicente, várias investidas europeias ocorreram na Terra de Vera Cruz, em busca de madeiras para tingimento, especialmente o pau-brasil. Encontrado, sobretudo, entre o Cabo de São Roque (RN) e Cabo Frio (RJ), sua exploração, entre os anos de 1500 e 1532, pode ter alcançado o valor médio de 300 toneladas anuais (Simonsen, 2005, p. 79).

Contudo foi a produção açucareira e, portanto, o cultivo da cana-de-açúcar a atividade econômica que deu outra magnitude a esse impacto iniciado anteriormente, provocando uma série de modificações na paisagem. Tal impacto é ainda mais importante ao se considerar que ele é irreversível, ou seja, a grande biodiversidade que caracteriza esse sistema florestal não é resiliente, dificilmente recuperando o seu estado original após a ação antrópica.

O seu desmatamento intensivo provavelmente deve ter provocado uma grande perda em termos de diversidade genética e orgânica. Acrescenta-se ainda que a Floresta Tropical Atlântica se estende pelas áreas de mata de galeria dos rios. E foram exatamente as planícies fluviais, onde essas matas de galeria se estabelecem, as áreas primeiramente ocupadas pela cana-de-açúcar. Assim ocorreu na Ilha de São Vicente, nas Capitanias de Pernambuco, na Baía de Todos os Santos e na Baía de Guanabara. E assim ocorreu em São Paulo, quando os canaviais se expandiram pelas planícies dos rios Tietê, Piracicaba e Mogi-Guaçu.

A Mata Atlântica, no trecho paulista, adentrava originalmente 800 a $900 \mathrm{~km}$ para o interior, alcançando a margem esquerda do rio Paraná, enquanto no Nordeste oriental apresentava menos de $100 \mathrm{~km}$ de largura; no Sul da Bahia, pouco mais de 100-150 km; no Espírito Santo e Nordeste de Minas Gerais, 300-400 km (Ab’Sáber, 1956, p. 17). A dimensão desse impacto, portanto, não se limitou apenas às áreas mais litorâneas, tendo em vista, no final do século XVIII, o cultivo da cana-de-açúcar ter avançado pela Depressão Periférica Paulista, coberta pela floresta pluvial.

Considerando-se que no início do século XIX o estado de São Paulo devia apresentar o equivalente a $81,80 \%$ de seu território coberto por Mata Atlântica, o equivalente a 20.450.00o hectares (Victor et al, 2005), os efeitos dessa expansão canavieira afetaram de modo inde- 
lével a cobertura florestal original, mesmo que menos expressiva areolarmente, se comparada com o processo posterior de desmatamento provocado pela cafeicultura na segunda metade do século XIX e no século XX.

Para os senhores de engenho, a Mata Atlântica representava uma fonte de acesso às suas ambições. Era nela que se obtinha a madeira necessária para as construções do engenho e para alimentar as fornalhas, e era sob ela que se encontravam os melhores solos para o cultivo da cana-de-açúcar. Apesar da produtividade dos engenhos banguês, individualmente, ser baixa, o que demandava extensões de terra cultivadas não tão altas, o número de banguês nas regiões açucareiras, com o passar das décadas, elevou-se exponencialmente. Em 1570, eram 60. Em 1689, esse número já havia passado de 528 (Schwartz, 2005).

Tal incremento levou à eliminação de quilômetros de florestas. Os dados estatísticos a respeito do volume de biomassa retirado da floresta ou da área ocupada pelo cultivo da cana-de-açúcar, entre os séculos XVI e XVIII, são escassos, devido, em parte, ao desinteresse da organização dessas informações, e também pela "proibição formal de publicações relativas ao comércio e aos lucros portugueses" (Simonsen, 2005, p. 141), o que dificulta o alcance da dimensão exata da produção açucareira nesses séculos. Outra questão é a discordância entre os poucos dados disponíveis. Por exemplo, enquanto Schwartz (1985, p. 150), apoiado em dados de Jácome Monteiro, aponta que a produção açucareira, em 1614, era de 700.000 arrobas, isto é, de aproximadamente 10.500 toneladas, Simonsen (2005, p. 142), baseado em dados de Gândavo, Fernão Cardim, Gabriel Soares, Frei Salvador, indica que a produção, em 1600, era de cerca de 2 milhões de arrobas, ou seja, 30.000 toneladas.

Apesar da carência e da inexatidão dos dados, é relevante o estabelecimento de um panorama acerca dos impactos causados pelo cultivo da cana-de-açúcar e da produção de seus derivados nos primeiros séculos da atividade canavieira no Brasil, a fim de demonstrar como o seu cultivo e as técnicas empregadas foram determinantes para a redução da conformação original da Mata Atlântica. 
Considerando a estruturação espacial primária de 1 milhão de $\mathrm{km}^{2}$ da Mata Atlântica e a conjectura de Dean (1996), de que em algumas áreas a sua biomassa vegetal tenha chegado a 600 toneladas por hectare, pode-se inferir que a produção de biomassa vegetal total da floresta pluvial possa ter girado em torno de 6 bilhões de toneladas.

Dean (1995, p. 96) considerou que, entre os séculos XVI a XVIII, a produtividade média de cana-de-açúcar por hectare era de 50 toneladas, e que o coeficiente extrativo era de $3 \%$ por peso de cana, resultando em uma área de cerca de $120 \mathrm{~km}^{2}$, ou seja, de 12.000 hectares, ocupada por canaviais, e a consequente eliminação de $1.000 \mathrm{~km}^{2}$ de Mata Atlântica até 1700.

De outra maneira, tomando-se como base que para o funcionamento da moenda nos engenhos baianos, nesse mesmo período, durante um dia, era necessária uma área de $4.356 \mathrm{~m}^{2}$ de cana cultivada (Ferlini, 1984, p. 33); de que a temporada média de moagem, no século XVII, era em torno de 200 a 220 dias (Schwartz, 1985, p.99); que em 1570, havia cerca de 60 engenhos no Brasil; e que, em 1689, esse número já era de 528 (Schwartz, 2005), pode-se inferir que, em 1570, mais de 5.000 hectares de floresta haviam sido convertidos em canaviais, e que em 1689, essa extensão deve ter girado em torno dos 50.000 hectares. Como a cada 20 anos eram necessárias novas terras virgens para o plantio de novos canaviais, a fim de se manter a produtividade, pode-se supor que, no período de 1550 a 1850 , houve 15 ciclos de desmatamentos. Se adotarmos que a média de desmatamento, para mais ou para menos, girava em torno de 50.000 hectares, em 15 ciclos, o total de área desmatada em 300 anos pode ter alcançado o total de 750.000 hectares ou $7.500 \mathrm{~km}^{2}$.

Outra forma de raciocínio pode ser feita baseada na média de produção de quilos de açúcar por hectare nos engenhos baianos entre 1584 e 1816, que girava em torno de $1.782 \mathrm{~kg}$ de açúcar por hectare de cana cultivado. Adotando-se esse rendimento como o médio de todos os engenhos no Brasil, pode-se supor que eram necessários cerca 20.650 hectares por ano de área plantada de cana-de-açúcar para a produção média de 36.799 toneladas de açúcar por ano, conforme a Tabela 2. Tomando-se como base os 15 ciclos de desmatamento calculados an- 
teriormente, estima-se que a área total desmatada no período de 300 anos pode ter alcançado 309.750 hectares ou $3.097 \mathrm{~km}^{2}$.

Tabela 2. Produção média de açúcar no Brasil (ton) no período de 1614 a 1875.

\begin{tabular}{|c|c|}
\hline Ano/Safra & Produção \\
\hline 1614 & $10.500^{1}$ \\
\hline 1710 & $19.008^{1}$ \\
\hline 1796 & $34.276^{1}$ \\
\hline 1822 & $70.413^{2}$ \\
\hline 1831 & $76.440^{2}$ \\
\hline $1851-1855$ & $123.409^{2}$ \\
\hline $1861-1865$ & $126.763^{2}$ \\
\hline $1871-1875$ & $170.543^{2}$ \\
\hline Total & 294.391 \\
\hline Média & 36.799 \\
\hline
\end{tabular}

Fontes: ${ }^{1}$ Schwartz, 1985, p. 150; ${ }^{2}$ Simonsen, 2005. Org.: dos autores, 2016.

Pautando-se nessas aproximações e considerando-se a produção de 600 toneladas de biomassa por hectare (Dean, 1995), estima-se que nos períodos colonial e imperial, tomando-se como base as áreas desmatadas de 3.097 ou de $7.500 \mathrm{~km}^{2}$, o volume de biomassa eliminado devido ao plantio da cana-de-açúcar tenha sido entre 185.850 .000 a 450.000.000 toneladas, grande parte queimada nas fornalhas dos engenhos.

Mantendo esse raciocínio e estendendo-o para São Paulo, onde a produção açucareira teve grande relevo em meados do século XIX, o número de engenhos nas vilas que compunham o denominado Quadrilátero do Açúcar - Mogi Mirim, Itu, Piracicaba, Capivari Campinas - em 1854, era de 386. Portanto, aproximadamente 30 mil hectares de cana foram cultivados, sendo ao redor disso a provável área desmatada para a implantação dos canaviais.

Em certas regiões, o direcionamento da terra para o cultivo da cana-de-açúcar foi tão intenso que gêneros alimentícios começaram a 
faltar. Foi o caso de Campos dos Goytacazes, RJ, onde a conversão rápida de lavouras de subsistência em canaviais fez com que, em 1793, a fome se alastrasse (Oscar, 1985, p. 52).

Para a total limpeza do terreno, a queimada era a prática preferida. Em solos de floresta tropical, esse procedimento destruía as micorrizas, associação entre fungos e raízes de algumas plantas, importante para a absorção de água e sais minerais. As micorrizas também eram eliminadas durante a limpeza dos canaviais, enquanto os escravos, com suas enxadas, retiravam as ervas daninhas. Esse processo possibilitava a permanência do cultivo por períodos mais prolongados, reduzindo a necessidade do pousio frequente e, consequentemente, a busca por novas terras em outra área florestada. Por outro lado, eliminava definitivamente qualquer possibilidade de regeneração da floresta (Dean, 1996, p. 93).

A eliminação da floresta se dava de modo seletivo, pois algumas madeiras eram destinadas para ser lenha nas fornalhas, outras para confeccionar objetos, como as próprias moendas e andaimes das casas, enquanto as madeiras nobres serviam para os móveis dos senhores de engenho e para a exportação para a Europa. Para se ter a dimensão desse processo, em 1779, 1.213 e 1.654 dúzias de jacarandás foram exportadas através do Porto do Rio de Janeiro para Lisboa e para o Porto (Friedman, 1999, p. 107).

No engenho, muitos objetos demandavam também madeiras de lei da Mata Atlântica. Moendas, bolandeiras, rodetes eram feitos especialmente do tronco da cabreúva (Myrocarpus frondosus), pesado e resistente. E tonéis que transportavam a cachaça eram feitos preferencialmente de canela (Ocotea spp) (Petrone, 1964, p. 104; Schwartz, 1988, p. 111/112; Dean, 1996, p. 193)

Até a introdução das primeiras centrífugas no Brasil, por volta da segunda metade do século XIX, quando foi possível a obtenção de um açúcar mais seco, passível de ser transportado em sacos de tecido, grandes caixas de madeira foram utilizadas para o transporte do açúcar à Europa, conforme já foi dito, para as quais eram escolhidas as que não conferiam cor ou sabor, como a do jequitibá (Cariniana legalis ou Cariniana estrellensis), do camaçari (Caraípa densifolia 
Mart) e da tapinhoã (Mezilaurus navalium) (Schwartz, 1988, p. 113; Dean, 1996, p. 193).

Embora o tamanho variasse bastante, em geral, ao final do século XVII, mediam em torno de 1,8 m por o,6 metro, e em 1898, a Coroa limitou o peso de 40 arrobas para cada caixa, incluindo o peso do açúcar (Schwartz, 1988, p. 113). Nesse sentido, Engemann (2010), baseado em Schwartz (1988), aponta que

Teríamos, portanto, algo do tamanho de um caixão, com um volume de
$0,65 \mathrm{~m}^{3}$ para pouco mais de $300 \mathrm{~kg}$. Assim, a caixa de $550 \mathrm{~kg}$ [aproxi-
madamente as 40 arrobas] de açúcar demandaria um volume de cerca
de $1,08 \mathrm{~m}^{3}$. As faces de um sólido que comportasse tal volume, se so-
madas, teriam uma área de $7 \mathrm{~m}^{2}$. Admitindo-se uma espessura de 3
$\mathrm{~cm}$, teríamos um volume de madeira de $0,21 \mathrm{~m}^{3}$ por caixa (Engemann,
2010, p. 130).

Considerando-se os valores das exportações de açúcar obtidos em Simonsen (2005, p. 148-153), de 1535 a 1831, e em Eisenberg (1977, p. 260/261), de 1841 a 1875, quando a implantação de centrifugadores provavelmente já havia se dado na maior parte dos grandes e médios engenhos, a quantidade de açúcar exportado até esse ano pode ter alcançado a casa de 1.494.081 toneladas, o que necessitaria de cerca de 2.716 .510 caixas, com a demanda de $5.700 .461 \mathrm{~m}^{3}$ de madeira. Engemann (2010, p.130), por meio de levantamentos em floresta atlântica no RJ, descreve que "os maiores exemplares arbóreos encontrados forneceram entre 5 e $7 \mathrm{~m}^{3}$ de madeira aproveitável do fuste," o que nos leva a admitir que, para $5.700 .461 \mathrm{~m}^{3}$ de madeira, seriam necessários de 114.093 a 814.356 indivíduos arbóreos.

Além da floresta primária, cujos solos eram os preferidos para o cultivo da cana-de-açúcar, por serem mais férteis, árvores das matas secundárias e dos manguezais também eram cortadas anualmente para serem queimadas nas fornalhas ou para servirem como cinza para purgar as impurezas do caldo. Supondo-se que cerca de 200 toneladas de biomassa adequadas à produção de lenha pudessem ser encontradas em único hectare de floresta e que cerca de 15 quilos de lenha, em mé- 
dia, eram queimados para cada quilo de açúcar produzido, aproximadamente 210 mil toneladas de matas secundárias e florestas de mangue foram eliminadas até 1700 (Dean, 1996, p. 96/97).

Com o emprego de novas tecnologias, mais econômicas em relação ao uso de combustível, principalmente no século XIX, sete quilos de lenha por quilo de açúcar talvez seja um número mais próximo da realidade no período entre 1700-1850. Com a exportação de 2,6 milhões de toneladas nesse período, estima-se a demanda de 18 milhões de toneladas de madeira e o consumo de novecentos $\mathrm{km}^{2}$ de floresta para essa finalidade (Dean, 1996, p. 192).

O corte seletivo e o transporte da madeira por longas distâncias indicam que a extração de madeira alcançou grandes extensões territoriais, o que pode ter modificado o tamanho e a distribuição das populações das espécies das madeireiras. De acordo com Engemann et al (2010), o corte seletivo por mais de 200 anos pode ter comprometido o sistema florestal da seguinte maneira:

a) pela eliminação dos indivíduos de grande porte, os quais são importantes para a produção de sementes; b) pelos danos causados aos indivíduos jovens durante a exploração, provocando prejuízo ao estoque remanescente e, dessa forma, reduzindo a população de certas espécies; c) pela abertura no dossel, que cria condições para a entrada do fogo na floresta, comprometendo as espécies menos resistentes ao fogo (Engemann et al., 2010, p. 137).

Era tão grande o consumo de madeira para alimentar as fornalhas do engenho e para a construção dos edifícios, que desde 1677 um regimento do governador geral orientava que não deveriam ser construídos engenhos perto um do outro, "porque muito mais importaria menos Engenhos com lenhas bastantes, que haver mais com falta de lenhas, e consumir-se de maneira que venha a faltar a todos, e perderse tudo" (Documentos Históricos, vol. VI da série e IV dos Documentos da Biblioteca Nacional apud Petrone, 1964, p. 74).

Em 1682, foi expedida uma provisão que impedia a instalação de engenhos a menos de meia légua, cerca de $3,3 \mathrm{~km}^{2}$, de distância um 
do outro, com o objetivo de evitar a falta de madeira para o trabalho nos engenhos. Com semelhante teor, em 1802, D. João VI assinou um decreto indicando que a dificuldade para a aquisição de madeiras permanecia no rol de preocupações governamentais.

Em São Paulo, no início do século XIX, a dificuldade na obtenção de lenha pode ter sido um dos motivos que levou à penetração da cana-de-açúcar em direção ao interior, bem como ao desenvolvimento da cultura cafeeira, cujo beneficiamento não necessitava de lenha (Petrone, 1964, p. 75/76). Sob outra perspectiva, Dean (1996), tomando como base os cálculos de plantio de cana-de-açúcar até 1850, considera pouco provável que áreas tenham sido abandonadas por causa da falta de lenha, apesar dos registros a esse respeito. Ressalta que um engenho de porte médio geralmente produzia menos de 30 toneladas de açúcar por ano, demandando uma área com menos de 18 hectares e de menos de um hectare de mata para fornecimento de lenha, o que possibilitaria o cultivo da cana-de-açúcar de forma "totalmente sustentável por tempo indefinido, mesmo se a troca de campos fosse muito frequente" (Dean, 1996, p. 192).

Outros impactos, decorrentes da cadeia produtiva do açúcar nos engenhos banguês, foram causados. Com a exceção de algumas formas para pães de açúcar, de madeira, a maior parte era de barro. Além disso, tijolos e telhas utilizados nas construções faziam com que a extração de argila nos barreiros, localizados às margens de rios e estuários, adquirissem papel importante no ciclo produtivo do açúcar, ao mesmo tempo impedindo que a vegetação renascesse no entorno desses ambientes (Petrone, 1964, p. 106; Dean, 1996, p. 97/98).

Animais domésticos do domínio biótico euroasiático foram introduzidos, tais como porcos, galinhas, ovelhas, cabras e bois, modificando a fauna brasileira. O gado bovino era especialmente importante porque a maior parte dos engenhos o utilizava como força motriz para a moenda até o século XVIII, quando cavalos e mulas começaram também a ser usados. Além disso, os bois majoritariamente serviam como animais de carga, em carros de boi ou junta de tiro, tendo em vista os cavalos raramente serem utilizados e a primeira menção a jumentos, no Sudeste, ser de 1635. Dessa forma, infere-se que, para um engenho mé- 
dio, era necessário, aproximadamente, 100 animais, cuja expectativa de vida não passava de dois anos (Dean, 1996, p. 91/92/93).

Com exceção das onças, que os atacavam, esse animal não tinha competidores naturais, pragas ou parasitas no território. Consequentemente, o rebanho rapidamente aumentou de tamanho, atendendo a demanda dos colonizadores. As pastagens, geralmente localizadas nos campos que estavam em pousio, cresceram facilmente no clima úmido e quente (Dean, 1996, p. 91/92), e o pisoteio constante dos animais, reduzindo a capacidade de infiltração da água de chuva, dificultou ainda mais a regeneração da vegetação original.

Em relação às atividades próprias da manufatura do açúcar, o bagaço, resultante do esmagamento da cana nas moendas, era diariamente lançado no campo, onde ao final da safra era queimado (Ferlini, 1994, p. 38), servindo de certa forma como fertilizante. A cana-de-açúcar nessa época não sofria a queima pré-colheita e, portanto, não passava pelo processo de lavagem.

No primeiro século de colonização, igualmente importante para a implantação da cultura canavieira foi o trabalho indígena, cujo contato com o homem europeu promoveu modificações culturais em ambas as etnias. Os europeus se acostumaram a dormir em redes, a beber e mascar fumo, a usar instrumentos silvícolas para caçar e pescar, a construir embarcações de casca ou tronco escavado, a apreciar produtos da terra, como a mandioca, e, sobretudo, a cultivar ateando fogo na vegetação (Holanda, 1995, p. 47). Aos povos indígenas couberam os impactos adversos.

Apesar de, inicialmente, o contato ficar mais restrito aos grupos que ocupavam o litoral, de Maranhão até São Vicente, posteriormente, com a incursão dos europeus pelo sertão, estendeu-se aos demais povos do interior. Entre os povos indígenas mais numerosos, que viviam no litoral, e, portanto, mais afetados nesse período, estavam os da família linguística tupi-guarani, como os tupinambás, os tupiniquins e os potiguares (Schwartz, 1988). Mas outras tribos de outros grupos linguísticos também foram atingidas, tais como os aimorés, os caraíbas e os goitacás.

A escravização, a aculturação e a destribalização provocaram a modificação e mesmo a extinção das tradições culturais desses povos 
originais, que muitas vezes eram expulsos das terras consideradas adequadas para o plantio da cana por meio de engodo ou da violência. Além disso, doenças europeias, como a varíola e o sarampo, rapidamente infectavam os indígenas, provocando milhares de mortes.

Apesar de os dados quantitativos serem incertos, devido à falta de registros, o que é certo é que o desenvolvimento da cultura canavieira, desde a época inicial da colonização, engendrou modificações no território brasileiro, consequência direta da alteração do uso da terra, com a implantação de canaviais, pastos e barreiros, e com o uso de conhecimentos e de técnicas exógenas, oriundas da Europa, muitas vezes inadequadas ao ambiente tropical. Portanto, a implantação e a expansão canavieira, entre os séculos XVI e XIX, levaram a uma série de impactos socioambientais. Alguns mais pontuais, como a contaminação do solo e da água por dejetos de bovinos e a modificação de vias fluviais para a implantação das calhas que levavam a água aos engenhos reais. Já outros de grande magnitude, muitas vezes irreversíveis, como a devastação de trechos importantes da Mata Atlântica e o desmantelamento dos saberes culturais de tribos indígenas e mesmo a extinção de alguns desses povos originários.

De fato, a baixa produtividade dos engenhos banguês e a falta de conhecimentos e de técnicas para o plantio da cana-de-açúcar em solos não aptos naturalmente à herbácea fez com que os impactos mais significativos ficassem restritos às grandes áreas produtoras de açúcar no litoral brasileiro, sobretudo em Pernambuco, nos recôncavos da Baía de Todos os Santos e da Guanabara, e no interior de São Paulo, até a Depressão Periférica Paulista. Contudo, a introdução de novas tecnologias, a partir da instalação dos engenhos centrais e das usinas, em 1875, alteraria esse panorama. 


\section{UMA TRANSIÇÃO SUTIL: DOS ENGENHOS CENTRAIS ÀS USINAS}

2.1 A implantação dos engenhos centrais em terras brasileiras

No final do século XVIII, a economia açucareira brasileira apresentou um curto renascimento. A urbanização europeia e o consequente crescimento populacional nas cidades provocaram o aumento da demanda por açúcar. Ao mesmo tempo, as guerras de independência das Antilhas e o bloqueio continental napoleônico imposto contra a Inglaterra e, portanto, ao açúcar produzido por suas colônias, deram novo fôlego à produção brasileira.

Simultaneamente ao bloqueio inglês, Napoleão, por sua vez, passou a estimular a produção de açúcar no solo europeu a partir da beterraba, baseada em uma técnica desenvolvida, em 1747, por Andrés Magraff, químico prussiano. As implicações desse processo foram enormes. Pela primeira vez, um produto tropical podia ser substituído por outro produzido na zona temperada (Mintz, 2003, p. 40). Assim, após o fim do bloqueio continental, os produtores europeus conquistaram a proteção governamental, desenvolvendo amplamente a indústria açucareira proveniente da beterraba e integrando-se ao mercado internacional, fazendo com que os preços mundiais entrassem em rápido declínio.

Desde 1840, a maior parte do açúcar brasileiro era vendida à Inglaterra. Com a proliferação das refinarias em solo inglês, entre 1854 e 1874, a Inglaterra impôs tarifas à importação de açúcar refinado, o que, para os comerciantes brasileiros, significou uma redução de preço 
de $25 \%$ a $33 \%$, além dos custos com o transporte de impurezas contidas no açúcar mascavo, sem valor econômico (Eisenberg, 1977, p. 50).

Com a introdução do açúcar de beterraba, no decênio de 1870 , o Brasil perdeu praticamente por completo o mercado inglês, o qual foi substituído pelo norte-americano, único ainda não dominado pelo açúcar de beterraba (Eisenberg, 1977, p. 48).

Mas outro golpe seria desferido na débil economia açucareira brasileira ao final do século XIX - a mecanização do processo fabril de açúcar em várias colônias espanholas, inglesas, holandesas e territórios norte-americanos. A introdução de processos mecânicos em Cuba, entre 1790 e 1830, melhorara extremamente os métodos de fabricação do açúcar, aumentando a sua produtividade e possibilitando o alcance, pela primeira vez, da cifra de 1 milhão de toneladas por ano e o posto de principal fornecedor de açúcar no mercado externo, seguido por Java.

Uma das principais chaves para o sucesso cubano e de Java foi a abundância de capitais. Em Cuba, capitalistas espanhóis, hispano-americanos e cubanos financiaram as primeiras plantações de cana a taxas mensais de juros não superiores a 1,5\%. Em 1860, 70\% dos 1.350 engenhos cubanos adotaram a máquina a vapor e 30 mil pessoas imigraram para o país, incluindo, entre estas, técnicos, agrônomos e plantadores de açúcar. A produção passou de 447.000 toneladas, em 1860, para 726.00o toneladas, em 1870, decrescendo apenas nas guerras de independência, mas rapidamente voltando a crescer, e chegando ao valor de 1.054.00o toneladas em 1893 (Funes-Monzote, 2008).

Em Java, foi majoritariamente o capital do governo holandês que propiciou o incremento da tecnologia açucareira. A partir de 1830, moendas de madeira foram substituídas pelas de ferro; a tração animal deu lugar ao uso da água e depois ao vapor; caldeiras a vapor e centrífugas foram introduzidas. A tecnologia utilizada em usinas de açúcar de beterraba europeias foi sendo implementada em solo javanês. Depois de 1870 , a iniciativa privada possibilitou uma nova onda de mecanização e, após 1880, o investimento de capitais financeiros fez com que a indústria açucareira de Java se tornasse uma das mais eficientes do mundo (Wolters, 1992, p. 426). 
Após a independência cubana, em 1898, os americanos monopolizaram o financiamento dessa indústria e tornaram-se um dos principais compradores do açúcar cubano. O capital investido em tecnologia e mão de obra especializada fez de Cuba, juntamente com Java, o país mais modernizado e produtivo na produção de açúcar.

Embora os dados da Tabela 3 sejam referentes apenas à exportação de açúcar pelo Brasil, ilustram o efeito devastador na produção brasileira da inserção das mudanças tecnológicas introduzidas em Cuba e Java, ressaltando-se que essas mudanças foram incorporadas em vários engenhos de várias colônias, como foi o caso de Porto Rico, Guiana Inglesa, Ilhas Maurício e Filipinas. Dessa forma, durante todo o século XIX, apesar das exportações de açúcar não cessarem, cada vez mais o Brasil passou a ter papel secundário no mercado açucareiro internacional, fazendo com que, nos primeiros anos do século XX, a produção brasileira fosse inexpressiva em termos de produção mundial de açúcar.

Tabela 3. Produção de açúcar do Brasil, de Cuba e de Java (em toneladas) no período de 1841 a 1910.

\begin{tabular}{|c|c|c|c|}
\hline ANOS & BRASIL $^{1}$ & CUBA & JAVA \\
\hline $1841-45$ & 89.188 & & 61.570 \\
\hline $1846-50$ & 118.287 & & 90.392 \\
\hline $1851-55$ & 123.409 & 320.722 & 104.827 \\
\hline $1856-60$ & 106.243 & 394.200 & 126.783 \\
\hline $1861-65$ & 126.763 & 534.600 & 157.816 \\
\hline $1866-70$ & 105.939 & 682.000 & 157.816 \\
\hline 1871-75 & 170.543 & 682.000 & 198.873 \\
\hline $1876-80$ & 175.599 & 568.600 & 231.571 \\
\hline $1881-85$ & 228.302 & 505.215 & 321.469 \\
\hline $1886-90$ & 155.993 & 621.696 & 359.056 \\
\hline 1891-95 & 153.333 & 933.470 & 484.198 \\
\hline $1896-1900$ & 113.908 & 272.427 & 670.485 \\
\hline 1901-05 & 78.284 & 943.212 & 947.975 \\
\hline $1906-10$ & 51.338 & 1.393 .898 & 1.209 .098 \\
\hline
\end{tabular}


Outra questão economicamente relevante, que levou à grave crise do setor açucareiro no final do século XIX, foi a turbulência econômica originada nos Estados Unidos da América, e que depois se difundiu pelo mundo, provocando a depreciação dos produtos de exportação e a queda das taxas cambiais brasileiras após 1851. Em 1846, 1 \$ooo equivalia a 27 pennies $^{7}$, e em 1890, a 7,4 pennies (Eisenberg, 1977, p. 41). Para os pequenos e médios senhores de engenho, essa queda na taxa cambial foi um grande obstáculo para a modernização, tendo em vista ser necessário importar todo o maquinário.

Assim, ao final do século XIX, duas crises afetaram a produção açucareira brasileira. Uma, estritamente econômica, vinculada à concorrência internacional e à queda na taxa cambial. Outra, relacionada aos efeitos da abolição da escravatura, enfrentadas diferentemente pelos senhores de engenho das províncias. Alguns, substituindo paulatinamente os escravos por trabalhadores livres. Outros, mantendo os cativos até os últimos dias da escravidão e depois encarando a escassez de mão de obra e a queda na produção (Eisenberg, 1977, p. 235).

Diante dessa situação, era imprescindível a introdução de novos processos de produção do açúcar, mais eficientes, já utilizados em Cuba e em Java, para a recuperação do comércio açucareiro internacional. Afinal, desde 1838, Cail, da empresa francesa Derosne \& Cail, havia divulgado um tipo de engenho diferente, o qual foi instalado na ilha de Bourbon. Contando com modernas máquinas e processos para a produção do açúcar, era considerado como um dos exemplos das tecnologias desenvolvidas na Revolução Industrial (Canabrava, 1971, p. 108).

A unidade industrial centralizava a recepção da matéria-prima dos lavradores e dos antigos engenhos banguês, recebendo por isso o nome de engenho central. Diferentemente, portanto, dos antigos engenhos, a unidade cultivo-produção anterior dava lugar à divisão do trabalho entre o proprietário agrícola (cultivador de cana) e o produtor de açúcar. Do ponto de vista técnico, parecia a solução para o enfrentamento da concorrência do açúcar de beterraba, considerando-se a pos-

\footnotetext{
${ }^{7}$ Nos Estados Unidos, que usa o dólar norte-americano, é a menor fração monetária.
} 
sível redução de custo da produção industrial, devido à racionalização dos processos produtivos (Canabrava, 1971, p. 108).

De acordo com a concepção do engenho central, a divisão de trabalho promoveria o uso dos fatores de produção de forma mais eficiente, pois o agricultor poderia direcionar seus recursos apenas à agricultura, promovendo melhorias com o uso de fertilizantes, irrigação e mecanização, não havendo mais necessidade de dispender recursos para melhorar seu próprio engenho, podendo, até mesmo, abandoná-lo. Os proprietários dos engenhos centrais, por outro lado, poderiam investir seu capital no aprimoramento dos processos e em máquinas necessárias ao processo industrial, não necessitando mais investir em canaviais (Eisenberg, 1977, p. 111). Mas, para que isso acontecesse, era necessário que senhores dos antigos engenhos banguês cessassem a atividade industrial, desativando os velhos engenhos e enviando a cana para os engenhos centrais (Andrade, 1997, p. 184).

É fato que durante os períodos colonial e imperial alguns avanços tecnológicos ocorreram, mas de forma fragmentária e pontual, em um ou outro engenho, cujo proprietário, mais interessado, tinha se disposto a tal. Mas faltava continuidade, incremento na proliferação de novas técnicas nos engenhos, estabilidade dos progressos tecnológicos conquistados e, sobretudo, capital.

Tais melhoramentos tecnológicos exigiam despesas que variavam de 50 a 70 contos, possíveis de serem pagos apenas pelos grandes engenhos. Porém nove décimos dos engenhos eram pequenos e encontravam-se em situação crítica, não conseguindo quitar nem sequer seus impostos em dinheiro (Costa, 1969, p. 171). Dessa forma, a visão geral dos estadistas e dos senhores de engenho, na década de 1870 , era de que a modernização do setor açucareiro só poderia ocorrer com o apoio governamental para a obtenção dos capitais técnicos e financeiros necessários.

Assim, em 1875, é criada a Comissão Especial pelo Parlamento brasileiro, responsável pelo levantamento da situação agrícola no país, sobretudo da cana-de-açúcar, elaborando o parecer e o projeto de criação dos engenhos centrais de açúcar, apresentado na Câmara dos Deputados no mesmo ano. As recomendações da comissão serviram de 
base para a legislação sobre engenhos centrais e indicavam problemas concernentes à falta de treinamento profissional e de transporte, à carência de mão de obra e à falta de capital, bem como a necessidade de divisão do trabalho (Souza, 1978, p. XXII).

Dessa forma, em 1875, é promulgado o Decreto Legislativo $\mathrm{n}^{\mathrm{o}}$ 2.687, estabelecendo que o governo imperial garantiria juros de $7 \%$ por 20 anos sobre 30 mil contos "às Companhias que se propuserem a estabelecer engenhos centrais para fabricar açúcar de cana, mediante o emprego de aparelhos e processos modernos os mais aperfeiçoados" (Decreto Legislativo $\mathrm{n}^{0}$ 2.687/1875 apud Eisenberg, 1977, p. 113). Ao mesmo tempo, estabelecia a prévia isenção de impostos sobre a importação de máquinas e a mão de obra livre (Canabrava, 1971, p. 108-109). Iniciava-se a partir de então uma nova fase no setor canavieiro, marcada pela implantação de engenhos centrais, sobretudo em Pernambuco, Rio de Janeiro e São Paulo.

As preferências para a concessão do apoio imperial foram as companhias que não possuíam terras, não cultivavam cana-de-açúcar e não utilizavam mão de obra escrava (Andrade, 1997, p. 184). Geralmente, foram escolhidas empresas que operavam sob a forma de sociedades anônimas (Canabrava, 1971, p. 108), que já possuíam algum ajuste com as administrações provinciais e que eram associadas a proprietários agrícolas da região, a fim de garantir o suprimento de matéria-prima e, ao mesmo tempo, a revitalização das propriedades canavieiras (Souza, 1978, p. XXII).

Ressalta-se que, ao fixar o capital aplicado no teto de 30 mil contos de réis, o decreto excluiu grande parte de pequenos e médios lavradores de cana e proprietários de terra, favorecendo determinados grupos econômicos, já que a implantação de melhorias tecnológicas dependia de crédito bancário, o qual só era obtido mediante a apresentação de certas garantias, disponibilizadas pela elite agrária ou pelo capital estrangeiro.

$\mathrm{O}$ decreto imperial não fez distinção quanto à origem do capital, podendo ser nacional ou estrangeiro, assim como também não diferenciou as áreas exportadoras e não exportadoras de açúcar. Desconsiderando as diferenças regionais e suas diferentes caracterís- 
ticas socioeconômicas, acabou por se refletir de modo diferenciado nas várias províncias onde os engenhos centrais foram implantados.

Em 1877, foi implantado o primeiro engenho central brasileiro, o de Quissamã, no Rio de Janeiro, por uma sociedade firmada por fazendeiros da elite fluminense. A divisão de trabalho proposta pelo conceito do engenho central já não foi seguida nesse caso, pois os proprietários do engenho eram também os plantadores da cana que iria abastecê-lo. Logo depois, entraram em funcionamento em terras fluminenses os Engenhos Centrais de Barcelos (1878), de Queimado (1879) e Limão (1879), antes mesmo dos que seriam implantados no Nordeste, principal região produtora de açúcar na época (Andrade, 1994, p. 71).

Apesar da instalação desses primeiros engenhos, a falta de idoneidade de certas empresas concessionárias e o não cumprimento de cláusulas contratuais fizeram caducar alguns desses primeiros contratos de concessão (Costa, 1969, p. 172). A despeito dos incentivos fiscais imperiais, o insucesso inicial, juntamente com o crescente sentimento de inferioridade daqueles que se tornariam apenas fornecedores de cana, promoveram uma resistência muito forte à fundação dos Engenhos Centrais, fazendo com que até 1880 os resultados para a sua implantação não fossem promissores (Costa, 1969, p. 172)

Apenas a partir de 1881, com o Decreto Imperial $\mathrm{n}^{0}$ 8.357, os engenhos centrais se tornaram realidade. O governo imperial passou a especificar o montante que cada província teria direito na distribuição dos 30 mil contos de financiamento (Tabela 4) e a relacionar o capital de lucro assegurado com a produção de açúcar. Aos engenhos, com capacidade de moer 200 toneladas cana/dia, com produção prevista de 1.000 toneladas de açúcar por safra, ficava garantido o teto de 500 contos. Aos que tivessem o dobro dessa produção, 750 contos. Aos que produzissem 4 mil toneladas de açúcar por safra, 1.000 contos (Canabrava, 1971, p. 108; Eisenberg, 1977, p. 114). O decreto concedia também o direito de expropriação aos concessionários para facilitar o transporte da cana, mantendo a isenção dos impostos de importação e determinando a preferência no uso e na aquisição de terras públicas (Eisenberg, 1977, p. 114/115). 
Tabela 4. Distribuição dos fundos imperiais às províncias para a instalação dos engenhos centrais, por meio dos Decretos Imperiais $\mathrm{n}^{0} 8.357 / 1988, \mathrm{n}^{0}$ $10.100 / 1888$ e n $^{0} 10.393 / 1889$.

\begin{tabular}{|c|c|c|c|c|c|c|}
\hline \multirow{2}{*}{ PROVÍNCIAS } & \multicolumn{3}{|c|}{$\begin{array}{l}\text { Capital garantido } \\
\text { (Contos de réis) }\end{array}$} & \multicolumn{3}{|c|}{$\begin{array}{c}\text { Parcela do total } \\
\text { (\%) }\end{array}$} \\
\hline & 1881 & 1888 & 1889 & 1881 & 1888 & 1889 \\
\hline Pernambuco & 8.000 & 7.500 & 6.400 & 26,7 & 25,0 & 21,3 \\
\hline Bahia & 6.100 & 6.000 & 6.100 & 20,3 & 20,0 & 20,3 \\
\hline Rio de Janeiro & 5.600 & 5.000 & 5.000 & 18,7 & 16,7 & 16,7 \\
\hline Sergipe & 2.000 & 3.000 & 2.275 & 6,7 & 10,0 & 7,6 \\
\hline São Paulo & 1.900 & 1.900 & 2.000 & 6,3 & 10,0 & 7,6 \\
\hline Rio Grande do Norte & 1.500 & 1.400 & 1.000 & 5,0 & 4,7 & 3,7 \\
\hline Alagoas & 1.200 & 1.200 & 2.275 & 4,0 & 4,0 & 7,6 \\
\hline Paraíba & 700 & 900 & 1.150 & 2,3 & 3,0 & 3,8 \\
\hline Ceará & 700 & 400 & 400 & 2,3 & 1,3 & 1,3 \\
\hline Maranhão & 700 & 1.500 & 1.550 & 2,3 & 5,0 & 5,2 \\
\hline Pará & 700 & 400 & 400 & 2,3 & 1,3 & 1,3 \\
\hline Espírito Santo & 500 & 400 & 400 & 1,7 & 1,3 & 1,3 \\
\hline Minas Gerais & - & 100 & 900 & - & 0,3 & 3,0 \\
\hline Município Neutro ${ }^{1}$ & 400 & 300 & - & 1,3 & 1,0 & - \\
\hline TOTAL & 30.000 & 30.000 & $30.000^{2}$ & 100 & 100 & 100 \\
\hline
\end{tabular}

1 Unidade administrativa que existiu entre 1834 e 1889, correspondente à sede da então Província do Rio de Janeiro (IBGE, [s.d.]).

2 “Erros tipográficos, presumivelmente, são responsáveis pelos 150 contos que faltam”. (EISENBERG, 1977, p. 115).

Fonte: EISENBERG, 1977, p. 115. Org.: dos Autores, 2019.

Em 1888 e 1889, o governo imperial fez a sua última tentativa de incentivar a instalação dos engenhos centrais por meio dos Decretos $\mathrm{n}^{0}$ 10.100/1888 e $\mathrm{n}^{\mathrm{0}}$ 10.393/1889, que concederam subsídios maiores para engenhos de menor porte. No entanto, os resultados ínfimos encerraram a era dos engenhos centrais. 


\subsection{A expansão dos engenhos centrais em}

\section{Pernambuco, Bahia, Rio de Janeiro e São Paulo}

As três províncias que receberam maior montante de subsídios governamentais foram Pernambuco, Bahia e Rio de Janeiro. São Paulo, apesar de ser a quarta província a receber maiores subsídios, após Sergipe, apresenta especificidades importantes a serem destacadas, pois apresenta a gênese para a explicação de como o maior complexo do setor canavieiro iria posteriormente estar localizado em terras paulistas.

Até 1850, na Província de Pernambuco, apesar dos plantadores de cana terem a posse da maior parte da Zona da Mata, apenas pouco mais de um quinto dessa terra era utilizada produtivamente. $\mathrm{O}$ uso de carros de boi para o transporte da cana até os engenhos e dos produtos beneficiados até Recife era oneroso e a tecnologia utilizada até então nos banguês permitia a moagem de uma média de 25 toneladas de cana/ dia, impedindo a expansão dos canaviais, já que grande parcela da cana não seria moída. Assim, parte dos agricultores preferia deixar a terra como reserva, mantendo a população livre, mas servindo para várias finalidades econômicas e políticas. Arrendatários e posseiros cultivavam alimentos e cana para uso próprio e para o engenho e (Eisenberg, 1977, p. 148-150) conforme os desígnios do senhor da terra.

Esse panorama só iria se alterar com a implantação dos engenhos centrais. Entre as décadas de 1850 e 1880, o número de engenhos aumentou de 1.300 para 1.650, o que, juntamente com as melhorias tecnológicas, contribuiu para mais que dobrar a produção açucareira (Eisenberg, 1977, p. 146/148). Apesar da crise no mercado externo, o incentivo imperial e provincial para a construção de modernos engenhos e ferrovias que facilitassem o transporte da matéria-prima e dos produtos canavieiros deu novo fôlego ao setor açucareiro.

Pernambuco foi a província que recebeu a maior parcela dos fundos distribuídos pelos decretos imperiais que subsidiaram os engenhos centrais. O primeiro engenho central que entrou em funcionamento nessa província foi construído pela empresa inglesa Central Sugar Factories of Brazil Limited (CSFB), que recebeu duas concessões, em 1881, e a metade do montante do subsídio correspondente à Província 
pelo decreto de 1881 para a construção de seis engenhos centrais para a produção de 2.600 toneladas de açúcar (Eisenberg, 1977, p. 115).

Nas safras de 1884-1885 e 1885-1886, quatro desses engenhos foram colocados em operação: Santo Inácio (Cabo) e Firmeza (Escada), em 1884; Cuyambuca (Água Preta) e Bom Gosto (Palmares). Contudo, a sua produtividade foi igual ou menor a dos engenhos tradicionais (Eisenberg, 1977, p. 117).

A CSFB instalou nesses engenhos máquinas usadas, muitas vezes enferrujadas, adquiridas em engenhos ingleses do Egito. Construiu edifícios com problemas, apresentando paredes inclinadas e rachadas. Tais fatos acidentavam trabalhadores e atrasavam a moagem da cana madura que ficava nos campos de cultivo. Para remediar o problema, no engenho de Cuyambuca, por exemplo, a CSFB ofereceu-se para pagar $10 \%$ do valor da cana não moída, o que deixou os agricultores, que tinham vendido ou abandonado suas próprias máquinas, furiosos (Eisenberg, 1977, p. 116/117).

Havia queixas em relação ao transporte da cana, cujos trens operavam irregularmente, deixando cair muita cana no chão, além do número pequeno de linhas e de mau funcionamento; em relação ao pagamento da cana, com deduções não autorizadas no peso da cana entregue, uso de balanças imprecisas e desonra nos créditos contratados; e também problemas em relação à disposição dos resíduos da destilaria, que poluía rios e matava o gado (Eisenberg, 1977, p. 117)

As autoridades pernambucanas atribuíam o insucesso dos engenhos da CSFB à má administração, à imperícia da direção técnica, à falta de operários idôneos e aos esbanjamentos dos gerentes e da diretoria. Por sua vez, a CSFB atribuiu tal insucesso à falta da matéria-prima, cara demais e de qualidade inferior; ao baixo preço do açúcar no mercado internacional; aos problemas com o maquinário e à interferência das autoridades brasileiras. Apesar de os preços do açúcar terem sofrido queda entre 1882 e 1886, os déficits foram cobertos pelo governo imperial, que pagou 644 contos, ou 7,7\% de lucro ao ano (em três safras) à CSFB sobre o investimento nominal de 2.800 contos. Mesmo assim, com muitos problemas e sem uma gestão eficiente, em 1886, a CSFB entrou em liquidação (Eisenberg, 1977, p. 120). 
Os engenhos Firmeza, Cuyambuca e Bom Gosto foram arrendados por grupos de ex-fornecedores de cana da CSFB e o engenho de Santo Inácio foi reequipado com o auxílio do governo estadual, convertendo-se em uma bem-sucedida usina na década de 1890 (Eisenberg, 1977, p. 120).

Do mesmo modo, outra empresa inglesa, a North Brazilian Sugar Factories Limited (NSFB) comprou, em 1882, duas concessões de engenhos centrais de dois brasileiros, com garantias de 6\% sobre 3.750 contos para a construção de sete engenhos. Mas até 1886 nenhum dos engenhos havia começado a operar devido a falsos contratos de fornecimento de cana feitos por um dos concessionários brasileiros, ao fracasso de uma importadora ilegalmente subcontratada pela empresa para adquirir maquinário e às tentativas da concessionária de adiar a construção dos engenhos para construí-los com o dinheiro das garantias imperiais a receber. Finalmente, em 1887, o engenho de Tiúma (São Lourenço da Mata) começou a operar (Eisenberg, 1977, p. 120/121).

Embora os resultados iniciais tenham sido razoáveis, o seu desempenho também foi deficitário, limitando os empréstimos aos agricultores, obrigando-os a pagar a metade do custo do transporte da cana. Além disso, a empresa negou-se a construir depósitos adequados para os resíduos do engenho, provocando a poluição dos rios e a morte de peixes (Eisenberg, 1977, p. 121).

Contrapondo-se ao desempenho frustrante das companhias inglesas, os brasileiros fundaram cinco engenhos centrais em Pernambuco, subsidiados pelo governo provincial, com resultados bastante promissores. Em 1885 e 1886, as Leis Provinciais n ${ }^{0} 1.860$ e 1.972 facultaram ao governo o empréstimo de até 1.700 contos a concessionários que deveriam ser agricultores residentes no município onde os engenhos seriam instalados, proibindo a transferência das concessões antes de começada a construção. Tais decretos determinavam ainda que a primeira metade do subsídio fosse paga após a aprovação dos planos do engenho e a outra metade depois de concluídas a sua construção e instalação (Eisenberg, 1977, p. 121-122). Assim, foram instalados a Companhia Usina João Alfredo (Goiana), o Engenho Central 13 de 
Maio (Palmares), o Engenho Central Trapiche (Sirinhaém), o Engenho Central Carassú (Barreiros) e a Usina Aripibu (Amaraji) (Eisenberg, 1977, p. 122).

Em Pernambuco, as leis e os decretos imperiais e provinciais previam no mínimo 31 engenhos centrais (Eisenberg, 1977, p. 123), mas poucos foram efetivamente instalados, podendo ser aventados três motivos principais: a especulação e a fraude; a instabilidade no fornecimento de matéria-prima; e a crise do mercado internacional do açúcar, que não estimulou o investimento de capitais, sobretudo de empresas idôneas, nos engenhos centrais (Eisenberg, 1977, p. 123).

Dessa forma, a partir dos anos 1890 até a primeira década do século XX, a crise no mercado de açúcar se propagou em Pernambuco, ao invés do aumento do número de engenhos, que havia ocorrido em meados do século XIX, houve decréscimo, inclusive de $8 \%$ da produção de açúcar (Eisenberg, 1977, p. 146).

$\mathrm{Na}$ Bahia, o primeiro engenho central implantado, e de fato o primeiro no Nordeste brasileiro, foi o Bom Jardim, inaugurado em 1880, por meio da concessão outorgada à família Costa Pinto (Araújo, 2002, p. 103-108). O Engenho Central Bom Jardim localizava-se na Freguesia do Bom Jardim, na faixa predominantemente açucareira do Recôncavo Baiano, com capacidade de moagem de 200 ton/dia de cana (Costa, 1969, p. 173; Araújo, 2002, p. 103-108).

Após vários prejuízos, foi vendido à Companhia Agrícola Usinas e Terras em 1891. Seu insucesso se deu por vários fatores. Primeiramente, o empreendimento foi extremamente prejudicado pelo atraso nas obras da Estrada de Ferro Santo Amaro, a ser construída pelo governo provincial e que serviria de apoio à implantação dos engenhos centrais. $\mathrm{O}$ atraso na inauguração da ferrovia fez com que o material construtivo e as pesadas máquinas do engenho tivessem que ser transportadas por tração animal, o que onerou o custo inicial do projeto em 800 contos de réis. Após a conclusão do engenho, tal fato também dificultou o escoamento da mercadoria aos portos do Recôncavo Baiano e mesmo depois de inaugurada, em 1883, em razão do pequeno número de vagões, foi considerada inadequada às demandas da região, sobretudo no período de safra (Araújo, 2002, p. 103-116/126). 
O segundo engenho central construído na Bahia foi o da Pojuca (Catu), inaugurado no final do ano de 1880, à margem da Estrada de Ferro Bahia ao São Francisco, por meio de concessão a uma sociedade anônima fechada. Apesar das mesmas dificuldades enfrentadas pelo Bom Jardim, a proximidade com a linha férrea evitou os prejuízos iniciais relativos à sua construção e facilitou a aquisição da matéria-prima, permitindo uma produção que manteve a sua operacionalidade e o êxito do empreendimento (Araújo, 2002, p. 116-122).

Tanto o Engenho Bom Jardim como o Pojuca foram construídos por grupos de empresários, famílias e sociedades fechadas, formados por fornecedores de cana, o que lhes garantiu o suprimento de matéria-prima (Araújo, 2002, p. 142).

Diferentemente, a empresa inglesa Bahia CentralSugar Factories obteve a concessão para a construção de quatro engenhos centrais, mas inaugurou apenas dois em 1886: Rio Fundo e Iguape, os quais não obtiveram sucesso. Inaugurados sem condições técnicas de funcionamento, com a finalidade apenas de assegurar o subsídio governamental ameaçado de ser cortado devido aos atrasos da obra, apresentaram várias interrupções no processo de moagem e, consequentemente, na captação da cana-de-açúcar contratada com fornecedores da região (Araújo, 2002, p. 142). Relatos constataram que os dois engenhos se encontravam completamente parados desde 1889 (Araújo, 2002, p. 123-134).

Assim, os investimentos realizados pela empresa inglesa na Bahia, como em Pernambuco, tiveram um caráter basicamente especulativo, não havendo interesse legítimo na comercialização do açúcar no mercado mundial, haja vista que, pela divisão internacional do trabalho, o papel do Brasil já havia sido definido: fornecedor de matéria-prima para as refinarias localizadas em países industrializados (Araújo, 2002, p. 142).

Apesar da introdução das novas tecnologias na parte industrial, no setor agrícola as técnicas de cultivo permaneciam as mesmas do período colonial, o que, associado à questão do transporte deficiente; aos graves problemas decorrentes das taxas de câmbio e do preço do açúcar no mercado mundial; às secas e doenças, que afetaram o cultivo em 1882; e à escassez de mão de obra devido à abolição da escravatura, 
levaram ao insucesso dos engenhos centrais baianos (Araújo, 2002, p. 103-116; Andrade, 1997, p. 97).

Embora produzido no Norte e no Sul do país, o açúcar tinha peso econômico diferente nas duas regiões, trazendo efeitos diversos, sobretudo para as Províncias do Rio de Janeiro e de São Paulo. Nessas duas províncias, o açúcar ocupava nessa época um papel secundário na pauta de exportação, cuja primazia era assumida pelo café. No Nordeste, o açúcar era a principal fonte de riqueza, líder na pauta de exportação, tornando-se, portanto, mais vulnerável à crise mundial, devido aos poderosos concorrentes no mercado internacional (Melo, 2009, p. 14/15)

Assim, o Decreto de 1875 teve maior resultado no Rio de Janeiro e em São Paulo, cuja produção açucareira era voltada para o mercado interno regional, onde o auxílio imperial para a implantação da infraestrutura necessária ao escoamento da produção era mais vigoroso e a economia encontrava-se capitalizada pela produção cafeeira (Melo, 2009, p.192/227; Penha, 2012, p. 227).

A principal região fluminense produtora de açúcar, desde o século XVIII, foi a de Campos de Goytacazes. Os primórdios da colonização dessa região datam do século XVI, quando Pero de Góis recebeu a capitania de São Tomé, onde em 1538 fundou a Vila da Rainha, hoje Campos de Goytacazes. Iniciou-se, então, o plantio de cana-de-açúcar com mudas trazidas de São Vicente, enquanto se erguia o engenho d'água de Itabapoana (Lamego, 1945; Andrade, 1994).

No entanto, a região ocupada por índios Goitacazes, acessíveis aos colonizadores, mas extremamente reativos diante de qualquer fato de violência contra seu povo, foi um ponto negativo à colonização dessa área. Por ocasião da morte de seu cacique, entregue a tribos canibais inimigas, e da imposição de castigos rigorosos contra aqueles que estavam sob o teto dos colonizadores portugueses, os índios Goitacazes assaltaram as fazendas e queimaram os canaviais, destruindo a Vila da Rainha e o Engenho de Itabapoana, sendo, a partir desse momento, abandonada a capitania (Lamego, 1945).

Apenas em 1627 é que a Capitania de São Tomé foi dividida em glebas, doadas a sete capitães portugueses, alguns donos de engenhos 
na Baía da Guanabara, e que a colonização se efetivou. No entanto, as características peculiares da região flúvio-lacustre, no delta do rio Paraíba do Sul, com constantes mudanças do leito do rio, inundações frequentes e assoreamento do baixo curso dos rios navegáveis, impossibilitaram a existência de bons portos naturais e o transporte das mercadorias, diferentemente de São Vicente, do Recôncavo Baiano e do Porto de Recife, em Pernambuco (Lamego, 1945; Andrade, 1994).

Dessa forma, a economia da região devotou-se à criação de gado, importante alimento para a população fluminense e força motriz para os engenhos de cana-de-açúcar da Guanabara. Só a partir de meados de 1700, quando os preços do gado começaram a declinar no mercado consumidor do Rio de Janeiro, é que a cana-de-açúcar se desenvolveu na região e Campos de Goytacazes se tornou, nas palavras de João Oscar (1985, p. 52), o "grande celeiro de açúcar da terra fluminense".

A baixada campista (Figura 11) é uma planície de inundação, com mais de 5 mil quilômetros quadrados de extensão (Dean, 1995, p. 92).É uma área muito plana, com solos aluviais e clima tropical estacional, o que favoreceu a expansão do cultivo da cana.

A partir de meados do século XIX, a difusão do vapor como força motriz de engenhos e embarcações que faziam o transporte da produção do açúcar pelo rio Paraíba do Sul e a introdução de novas técnicas produtivas possibilitaram o enriquecimento dos senhores de engenho da região de Campos, de São Fidélis, de Macaé e de São João da Barra, e o surgimento dos "barões do açúcar" em todo o Norte Fluminense. Títulos nobiliárquicos foram concedidos pelo governo imperial a fazendeiros da região, a pretexto dos serviços prestados à economia nacional, dada a aplicação de seus recursos na ampliação de seus estabelecimentos, como foi o caso de José Carneiro da Silva, o Visconde de Araruama, e de Domingos Alves Barcelos Cordeiro, o Barão de Barcelos (Silva, 2006, p. 4-5).

O poder econômico, social e político dos "Barões do Açúcar" influiu de forma contundente nas decisões políticas da capital imperial sobre a instalação da infraestrutura necessária à circulação do açúcar para o Rio de Janeiro (Silva, 2006, p. 5). Por causa da escassez da mão de obra e do pequeno conhecimento do governo imperial sobre várias das localidades da província, era comum que os fazendeiros que nelas 
Figura 11. Mapa do Norte Fluminense, com indicação de prováveis áreas de ocorrência de cana-de-açúcar a partir do século XVIII.

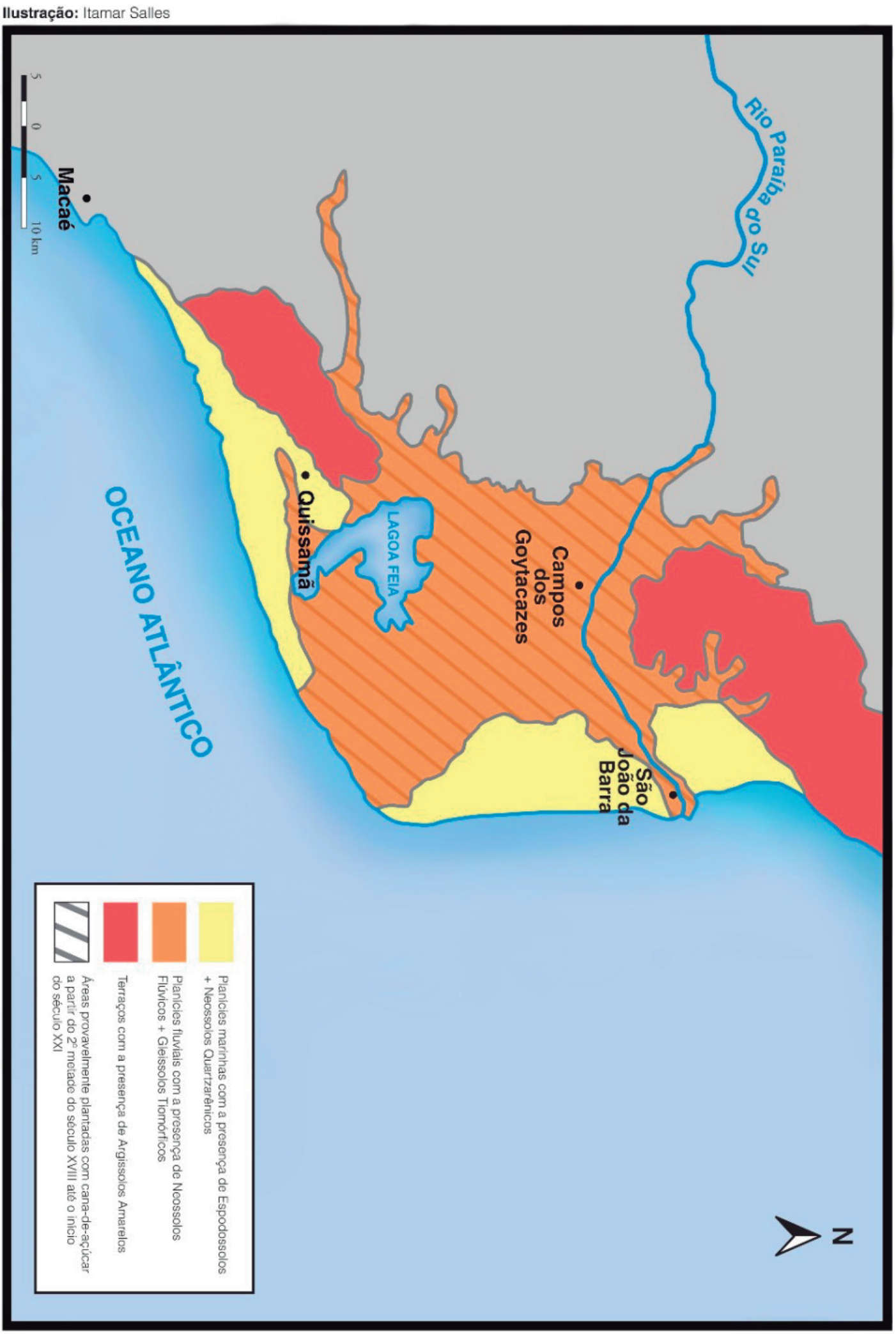

Fonte: IBGE, 1983b. Org.: dos autores, 2016. 
residissem se responsabilizassem pelas obras subsidiadas pelo governo, como foi o caso do Canal Campos-Macaé, que ficou sob a responsabilidade do Visconde de Araruama, deputado provincial, e de outros fazendeiros locais (Penha, 2012, p. 146).

O Canal foi uma obra monumental que demorou trinta anos para ser concluído, e rapidamente foi abandonado, após a inauguração das ferrovias. Com extensão aproximada de $100 \mathrm{~km}$ (Penha, 2012, p. 96) e o objetivo de transportar a cana da região açucareira do Norte Fluminense ao Porto de Imbetiba (Macaé), prosseguindo até o Porto das Caixas (Itaboraí), foi inaugurado em 1861. Em parte, a demora de sua conclusão deu-se pelos parcos recursos tecnológicos disponíveis na década de 1840 para enfrentar os desafios do ambiente natural decorrentes das inundações nos períodos de cheia dos rios e da falta de água em alguns períodos do ano, bem como a precária manutenção, ficando obstruído pelo assoreamento e pela vegetação (Penha, 2012, p. 187/240).

Ferrovias também foram construídas, como a Estrada de Ferro Macaé-Campos, inaugurada em 1875, interligada à linha férrea agrícola do Engenho Central de Quissamã; a Estrada de Ferro Campos-São Sebastião (1873); a Estrada de Ferro Campos-Carangola, MG (18761886); e a de Santo Antônio de Pádua (1876) (Melo, 2009, p.219). A produção dos engenhos centrais da região campineira seguia até o Porto de Imbetiba, integrada à ferrovia Macaé/Campos, de onde partia para o Rio de Janeiro (Penha, 2012, p. 187/207/208).

As facilidades de transporte e o poder político e econômico do Visconde de Araruama foram fatores decisivos para a instalação do primeiro engenho central no Brasil, o Engenho Central Quissamã, localizado em Macaé, em setembro de 1877, tendo como concessionária a Cia. Engenho Central de Quissamã (Silva, 2006, p. 5). Também foram instalados no Norte Fluminense os Engenhos Centrais de Barcelos (1878), cuja concessionária era a Cia. Agrícola de Campos, em São João da Barra; e de Pureza (1885), em São Fidélis (Silva, 2006, p. 5).

As companhias concessionárias eram pessoas jurídicas necessárias à implantação dos engenhos centrais, como determinava o Decreto de 1875, sendo constituídas no Norte Fluminense por capitais nacio- 
nais de famílias ligadas à produção cafeeira e açucareira, comerciantes e profissionais liberais (Melo, 2009, p.192).

O Engenho Central de Quissamã contou com a subvenção de mil contos de réis do Governo Imperial, e recebia a matéria-prima de sete engenhos menores de propriedade de seus próprios acionistas: Quissamã, Machadinha, Mantiqueira, São Miguel, Monte de Cedro, Santa Francisca e Melo (Penha, 2012, p.222).

A instalação dos engenhos centrais no Norte Fluminense foi favorecida por dois fatores. O primeiro, relacionado ao fornecimento da matéria-prima, que se deu de modo mais constante. Na região de Campos, era grande a quantidade de engenhocas e de pequenos produtores de cana, herdeiros de antigos posseiros que adquiriram terras no período colonial pela enfiteuse ${ }^{8}$ conferida pelas ordens religiosas e grandes famílias. Outro fator favorável foi a proximidade da região de Campos a dois mercados internos expressivos, Rio de Janeiro e Minas Gerais (Andrade, 1987, p. 186).

Em São Paulo, o crescimento econômico propiciado pela cafeicultura gerou um mercado consumidor de cerca de 1 milhão de pessoas. Estimando-se o consumo anual de $25 \mathrm{~kg}$ de açúcar por habitante, havia uma demanda de pouco mais de 20.000 toneladas. Desde 1860, a produção da província paulista não era mais suficiente para o abastecimento da população, havendo a necessidade da importação de mais da metade do açúcar do Rio de Janeiro e de Pernambuco (Melo, 2009, p.12/104).

Nesse contexto, a queda do preço do café, o amplo mercado consumidor, a mão de obra abundante advinda da cafeicultura, associados ao interesse dos ricos cafeicultores em novos investimentos, foram os elementos propícios para o desenvolvimento de uma agroindústria açucareira baseada na introdução de modernas tecnologias subsidiadas pelo governo imperial.

Pode-se dizer que a produção de açúcar financiou a introdução da lavoura cafeeira e o desenvolvimento da cafeicultura garantiu a ma-

\footnotetext{
${ }^{8}$ Enfiteuse: direito que confere a alguém o pleno gozo do imóvel mediante a obrigação de não o deteriorar e de pagar um foro anual, em numerário ou em frutos. (FERREIRA, 2009, p. 752).
} 
nutenção da agromanufatura açucareira com a criação de um mercado interno em constante expansão, a implantação das ferrovias e o acúmulo de capitais para serem investidos em outros setores (Melo, 2009, p.12/104).

Dessa forma, no último quartel do século XIX, foram implantados os quatro primeiros engenhos centrais da Província, três no antigo quadrilátero do açúcar - Porto Feliz (1878), Piracicaba (1882) e Capivari (1884) - e outro, na região cafeeira do Vale do Paraíba, em Lorena (1884) (Andrade, 1977, p. 56/158; Melo, 2009, p.212).

Apesar de a cultura da cana ter apresentado certa expressão em Porto Feliz no apogeu do ciclo do açúcar paulista, com 38 fazendas de cana produzindo 46.310 arrobas de açúcar, em 1854, a cultura canavieira não se desenvolveu tanto como em Campinas e Piracicaba (Petrone, 1964, p. 37). A partir de 1860, seus lavradores se dedicaram à lavoura de algodão, contando com apenas 11 fazendas canavieiras em 1873 (Melo, 2009, p.213). Com o declínio dos preços do algodão, na década de 1870, e o aumento do preço dos escravos devido à Lei do Ventre Livre, a cultura algodoeira entrou em crise (Melo, 2009, p.213).

Considerando o momento favorável propiciado pelo Decreto de 1875, fazendeiros, empresários dos setores ferroviário e industrial, pequenos lavradores e comerciantes que acumularam capital nas lavouras de cana, café e algodão do Oeste paulista organizaram a sociedade de ações "Companhia Assucareira de Porto Feliz", em 1876. O Engenho Central de Porto Feliz foi instalado na margem esquerda do rio Tietê, ao lado do núcleo urbano de mesmo nome, com capacidade de moagem de 125 toneladas de cana/dia e de produção de 7,5 toneladas de açúcar/ dia (Melo, 2009, p.216/217).

Com a inserção dos produtores agrícolas como sócios da Companhia Assucareira de Porto Feliz, desde o início, o suprimento de matéria-prima para o engenho ficou assegurado (Melo, 2009, p.215). Isolada entre duas ferrovias, a Ituana e a Sorocabana, a fábrica havia sido projetada para receber a cana-de-açúcar pelo rio Tietê, contando com a desobstrução do leito do rio na estação seca do ano, quando as águas baixavam e ocorria a safra canavieira, o que não ocorreu. Dessa forma, durante toda a sua primeira fase de operação, o transporte da 
matéria-prima para as moendas do engenho constituiu-se em um grande e, de fato, no principal problema a ser enfrentado pela indústria, levando, inclusive, alguns lavradores a continuar a fabricação do açúcar nos banguês (Melo, 2009, p.297/303).

A Companhia de Engenho Central de Piracicaba foi constituída por fazendeiros, produtores de café e de cana-de-açúcar, comerciantes e homens de negócio de Piracicaba, Itu, Indaiatuba e São Paulo (Melo, 2009, p.218), a partir da concessão imperial dos juros garantidos previstos pelo Decreto de 1875. Contudo, como ocorrera com o Engenho de Porto Feliz, houve a necessidade de empréstimos para a conclusão das obras.

No ano seguinte à concessão, a companhia construiu o engenho na margem direita do rio Piracicaba, em frente ao núcleo urbano, com capacidade mínima de moagem de 150 toneladas de cana/dia e produção de 960 toneladas de açúcar/ano (Melo, 2009, p.298).

Para o transporte da matéria-prima, foi utilizada a Estrada de Ferro Ituana, com a qual a companhia concessionária assinou contrato, possibilitando o transporte da cana-de-açúcar plantada a longas distâncias. Contava ainda com outros ramais que entrecortavam a região, um deles construído pela própria companhia, devido à obrigação contratada com o governo imperial, pela qual era obrigada a construir uma ferrovia de $15 \mathrm{~km}$ (Melo, 2009, p.271-271/298). O Engenho Central de Piracicaba foi o maior produtor de açúcar e aguardente dentre os quatro primeiros engenhos instalados (Melo, 2009, p.305).

Dez anos após a safra inaugural desses engenhos, as Companhias Açucareiras de Porto Feliz e de Piracicaba, em 1887-1888, entraram em falência. A dificuldade no suprimento de matéria-prima, pela precariedade do transporte, no caso do Engenho de Porto Feliz, e por problemas decorrentes de geadas e seca, a queda no preço do açúcar e a falta de mão de obra, em virtude da abolição da escravatura, levaram essas empresas a uma situação econômica insustentável (Melo, 2009, p.308).

O Engenho Central de Lorena foi inaugurado em 1884, com capacidade de moagem de 240 toneladas de cana/dia. Localizado no Vale do Paraíba, região tradicionalmente cafeeira, a companhia concessionária contava com investimentos da família mais rica da localidade, os 
Moreira Lima, de fazendeiros de café, comerciantes e banqueiros do Rio de Janeiro. Diferentemente dos Engenhos de Porto Feliz e Piracicaba, contava também com o aporte de pessoas jurídicas dos setores financeiro, comercial e agrícola (Melo, 2009, p.226/227/272/283).

O engenho se encontrava a 200 metros da estação ferroviária da cidade, utilizando para o transporte da matéria-prima, além da ferrovia São Paulo-Rio de Janeiro, o rio Paraíba do Sul, por meio de um sistema de transbordo a uma pequena ferrovia que ia da margem direita do rio até a casa de balança do engenho (Melo, 2009, p.274).

Apesar de não ter sido atingido pelo problema de falta de mão de obra, em razão da abolição da escravatura, tendo em vista utilizar, desde 1888, canas cultivadas no Núcleo Colonial das Cannas, o engenho passou por safras deficitárias desde 1883. Geadas, que atingiram os canaviais paulistas, e compromissos financeiros decorrentes da compra de novas caldeiras e do forno para a queima de bagaço levaram à sua desorganização financeira e produtiva e à falência e liquidação judicial do Engenho Central de Lorena em 1901 (Melo, 2009, p.251/308/318/321).

Capivari foi o quarto maior produtor de açúcar da Província paulista em meados do século XIX, com uma produção de 100.000 arrobas de açúcar em 70 fazendas (Petrone, 1964, p. 38). Henri Haffard, filho do cônsul geral da Suíça no Rio de Janeiro, associado a comerciantes ingleses, escolheu a pequena cidade para instalar o Engenho Central de Capivari. Por meio da venda da concessão para a instalação do engenho na praça de Londres, foi organizada a The São Paulo Central Sugar Factories of Brazil Limited, em 1882, única empresa estrangeira a implantar engenhos centrais em São Paulo (Melo, 2009, p.226; Andrade, 1977, p. 56/158)

O Engenho Central de Capivari foi implantado às margens do rio Capivari, sendo inaugurado em 1884 . O município era cortado pela Estrada de Ferro Ituana, distante 300 metros do engenho, cuja ligação foi efetivada por um ramal de $4 \mathrm{~km}$, construído pela empresa (Melo, 2009, p.226/277).

De forma semelhante ao ocorrido com os Engenhos de Porto Feliz e Piracicaba, a perda dos juros garantidos pelo Decreto de 1875 
por não ter se habilitado a exercer suas funções dentro do prazo, a geada, os problemas nas máquinas e a grande baixa no preço do açúcar levaram à falência o Engenho Central de Capivari, em 1885, após apenas um ano de operação (Melo, 2009, p.206).

Assim, em 1886, seus credores e dois terços dos acionistas da Companhia assumiram a fábrica, formando a Companhia Engenho Central de Capivari, presidida por um fazendeiro canavieiro, fornecedor de matéria-prima da companhia.

Tendo em vista a grande demanda pelo mercado interno paulista da maior parte do açúcar produzido pelos engenhos centrais, o setor canavieiro passou a atrair a atenção de empreendedores estrangeiros, sobretudo franceses. Sociedades anônimas passaram então a adquirir vários dos engenhos centrais e fazendas, entre 1889 e 1901, fundidos em 1907 na Societé de Sucreries Bresiliennes. Transferindo máquinas e locomotivas de um para outro, conforme a necessidade de ampliação de alguns deles, reorganizaram e ampliaram a produção, tornando-se a maior produtora de açúcar, aguardente e álcool do estado até 1940 (Melo, 2009, p.113/288; Meira, 2010, p. 10).

Dessa forma, paulatinamente, diferentemente do conceito inicial de engenho central, a produção do açúcar voltou a ser integrada à cultura agrícola, caminhando em direção à estrutura usineira, como será visto adiante, sem deixar, no entanto, de conservar o fornecimento de cana por terceiros (Melo, 2009, p.113/243).

O problema da falta de mão de obra com a abolição da escravatura foi parcialmente solucionado com a manutenção do fornecimento de cana por terceiros e de núcleos coloniais criados pelo governo, anteriormente, para abastecer os engenhos centrais, como em Lorena e Porto Feliz (Melo, 2009, p.243).

A partir de 1898, iniciou-se uma nova fase no setor canavieiro em São Paulo, a qual se prolongaria por várias décadas, até transformá-lo no estado maior produtor de derivados de cana do país. Novas unidades mecanizadas foram instaladas em Araraquara (1888), Franca (1898), Jaboticabal (1903), Campinas (1905) e Sertãozinho (1906), já com uma produção verticalizada, moendo a própria cana. Iniciou-se a expansão da fronteira agrícola em direção ao Planalto Ocidental Paulista, gra- 
ças às ferrovias construídas pelo estímulo financeiro dos cafeicultores (Melo, 2009, p.212-295/p.284).

Entre 1907 e 1910, das 77.000 toneladas de açúcar consumidos em São Paulo, 24.00o toneladas (30,8\%) eram produzidas por dez engenhos centrais: Lorena, S. Simão, Araraquara, Franca, Jaboticabal, Piracicaba, Monte Alegre, Capivari, Porto Feliz e Campinas (Melo, 2009, p.119). O aumento da demanda do açúcar no mercado interno e a crise no mercado do café, devido à superprodução e ao retraimento do mercado internacional, fizeram com que nas décadas de 1920 e 1930 houvesse uma significativa expansão dos canaviais e a implantação de usinas em São Paulo, que passou a disputar o mercado regional com Rio de Janeiro e Pernambuco (Melo, 2009).

Dessa forma, a ideia de instalação dos engenhos centrais se manteve durante apenas quinze anos (Canabrava, 1971, p. 109). Vários motivos podem ser aventados para explicar o seu fracasso. Em primeiro lugar, no momento da instalação dos engenhos centrais, não havia demanda para o açúcar branco para exportação, pois a Europa produzia açúcar de primeira qualidade a partir da beterraba e os EUA só se interessavam pelo mascavo, matéria-prima para suas refinarias, provido por Cuba (Perruci, 1978, apud Melo, 2009, p. 204).

Outra questão eram os problemas decorrentes da instalação de máquinas usadas ou defeituosas, sobretudo nas Províncias nordestinas, pelas companhias inglesas, transferidas de outras áreas produtoras de açúcar no exterior, constituindo-se em verdadeiros engenhos reformados. Sua manutenção e conserto eram muito difíceis e caras, tendo em vista a escassez de mão de obra especializada no Brasil (Canabrava, 1971, p. 110).

Mas o principal problema para a consolidação dos engenhos centrais foi a falta de continuidade do fornecimento da matéria-prima por uma série de motivos. Nunca o seu fornecimento foi regularizado, em razão de problemas relacionados ao transporte ineficiente, da dificuldade em se ajustar a produção ao trabalho livre, dos problemas causados pelas intempéries, da resistência de antigos senhores de engenho em se tornarem meros fornecedores de cana. Várias ações foram tomadas para evitar a ociosidade dos engenhos, como a elevação do valor da 
cana pago aos fornecedores, adiantamentos em dinheiro, instalação de colônias e núcleos de imigrantes, mas todas se mostraram infrutíferas (Canabrava, 1971, p. 110; Melo, 2009, p.241). Apenas com o aparecimento da usina, a partir do início da última década do século XIX, é que o problema foi solucionado (Canabrava, 1971, p. 110).

\subsection{Dos engenhos centrais às usinas}

Apesar de o governo republicano manter a denominação engenhos centrais até 1909, alguns já apresentavam as características típicas de usinas (Meira, 2010, p. 108) desde o final do século XIX. Tanto é que a primeira usina instalada no Brasil, a Usina do Limão, em Campos/RJ, entrou em funcionamento em julho de 1879 (Silva, 2006, p.7).

De fato, desde o final do Império houve um grande empenho para que os antigos grandes engenhos de açúcar passassem para o capital comercial, sobretudo estrangeiro, o que se deu pela política de juros garantidos e pelos engenhos centrais. No entanto, simultaneamente à instalação dos engenhos centrais, alguns senhores de engenho, em reação a essa política, implantaram unidades com modernas máquinas, mas integrando agricultura e indústria.

O que se observa é que o insucesso dos engenhos centrais não desestimulou a modernização da indústria açucareira. Com efeito, a falta de recursos dos agricultores e o desequilíbrio entre a tecnologia empregada na produção do açúcar e os métodos de cultivo da cana obrigaram as empresas concessionárias dos engenhos centrais a cuidar também da lavoura. Dessa forma, a tentativa de evitar o desabastecimento de matéria-prima e de alcançar um melhor rendimento de açúcar na cana processada levou ao retorno da integração outrora efetivada nos antigos engenhos banguês (Canabrava, 1971, p. 110; Perruci, 1978, p. 115), contudo com uma grande diferença, a economia açucareira anteriormente dominada por capitais predominantemente agrários e comerciais passava a ser "uma economia dominada por capitais predominantemente industriais" (Perruci, 1978, p. 115).

Apesar de apresentar características semelhantes na estrutura de funcionamento, a usina se diferenciava do engenho central, sobretudo no que se relacionava à divisão do trabalho. Enquanto no enge- 
nho central a matéria-prima deveria ser provida obrigatoriamente de fornecedores agrícolas, o que era gerido pelos decretos governamentais e fiscalizado pelos seus agentes, a usina se abastecia da sua própria matéria-prima, a qual, se desejasse, poderia também ser adquirida de outros agricultores (Eisenberg, 1977, p. 124; Silva, 2006, p. 7). De acordo com Eisenberg, "a usina era uma reencarnação moderna do engenho tradicional, em escala mais complexa e muito maior" (Eisenberg, 1977, p. 124).

O processo de transição dos engenhos centrais às usinas foi sutil, demorando apenas o tempo necessário para que os plantios próprios de cana-de-açúcar amadurecessem e para que as máquinas das usinas recém-implantadas estivessem instaladas (Meira, 2010, p. 108).

Após a Proclamação da República, com o fortalecimento do poder dos estados, os usineiros passaram a obter dos governos locais uma série de facilidades, relacionadas a financiamentos e isenções fiscais. Em vários estados governadores desenvolveram uma política altamente favorável a esses proprietários, que retribuíam com votos nas eleições, possibilitando a multiplicação de pequenas usinas, distribuídas sem o mínimo planejamento (Andrade, 1997, p. 159).

Em Pernambuco, os primeiros governos republicanos passaram a apoiar a implantação de usinas, aprovando em 1890 uma lei que oferecia empréstimos de 200 contos em títulos estatais a 7\% a quem construísse usinas com capacidade produtiva de 900 toneladas de açúcar por safra (Eisenberg, 1977, p. 125).

$\mathrm{Na}$ tentativa de evitar a falta de matéria-prima, determinava-se a relação preço da cana/açúcar e um zoneamento, segundo o qual se proibia a concessão de usinas na área de vizinhança de outras subvencionadas que já estivessem instaladas ou planejadas. Diferentemente do que havia ocorrido com os engenhos centrais, o empréstimo passava a ser liberado em etapas: a primeira parte, com a compra das máquinas e o restante do material para instalação; a segunda, quando o equipamento estivesse no local; a terceira, quando as instalações tivessem sido concluídas; e, a última, após a primeira safra processada (Eisenberg, 1977, p. 125). Estabeleceu-se ainda que caso "o usineiro deixasse de pagar os juros ou 5\% da amortização, durante dois anos, incorreria em juro de 
mora de 1\% ao mês e o Estado assumiria a direção da usina para cobrarse com as receitas realizadas" (Eisenberg, 1977, p. 125).

Baseado nessa lei e em outras formuladas posteriormente, mas com conteúdo semelhante, o governo pernambucano subsidiou, na última década do século XIX, a transmutação de muitos engenhos que já operavam como usinas e a construção de novas, totalizando 49 unidades. Contudo, com a crise dos primeiros anos do novo século, somente nove novas usinas foram implantadas até 1910, época que 409 engenhos encerraram suas atividades (Melo, 2009, p.207).

Apesar das facilidades dispostas para a implantação das usinas e do contexto do mercado interno favorável, foram poucas as empresas concessionárias que conseguiram sanar suas dívidas. Por volta de 1911, quando $75 \%$ da dívida deveriam estar liquidados com o Estado, somente quatro usinas a tinham realizado, transformando os empréstimos em doações, com consequências políticas importantes, mas com reflexos ainda mais importantes para a continuidade das usinas (Eisenberg, 1977, p. 130/131). Tanto que "Dos 62 engenhos centrais e usinas surgidos no estado até 1910, pelo menos 43 tinha recebido alguma forma de subsídio, os quais foram responsáveis por um terço de toda a safra açucareira de Pernambuco" (Eisenberg, 1977, p. 132).

Entre 1901-1914, Pernambuco exportou 50.000 toneladas de uma produção de 288.0oo. Voltando-se para o mercado interno, principalmente o Centro-Sul, Pernambuco levou vantagem, pois além da quebra das safras de estados nordestinos por causa da abolição, contou com o declínio da produção fluminense, a expansão do mercado consumidor paulista, o maior número de usinas (Melo, 2009, p.206) e a rede ferroviária consolidada.

Ressalta-se que, a princípio, a relação entre tradicionais senhores de engenho nordestinos e usineiros eram tensas, sobretudo devido aos contratos de fornecimento de cana e às condições de zoneamento que determinavam o seu fornecimento a usinas específicas. Essas tensões tornaram-se mais sérias, à medida que os usineiros foram adquirindo os engenhos dos antigos proprietários de terra e os submetendo à condição de meros fornecedores ou arrendatários (Eisenberg, 1977, p. 132). 
No Nordeste, de maneira geral, os usineiros descendiam dos senhores de engenho, os quais instalavam as usinas, sozinhos ou associados a pessoas ligadas por laços de sangue, como seus irmãos, cunhados e primos, cujas propriedades ou fazendas próximas à usina eram vinculadas como fornecedoras de matéria-prima. Os fornecedores, inicialmente, mantiveram seus engenhos banguês em funcionamento, mas após alguns anos fornecendo cana, tanto para os engenhos centrais como para as usinas, passaram a vender toda a cana produzida, desativando os engenhos.

Muitas vezes endividados pelos empréstimos obtidos no período de entressafra nas usinas, sem poder honrar suas dívidas, vendiam a propriedade à sua credora, que cada vez mais ampliava o patrimônio fundiário (Andrade, 1987, p. 185/186).

Até o final da Primeira República, com poucas exceções, o usineiro manteve as características do antigo senhor de engenho, administrando sua usina de modo patriarcal, geralmente dispensando, inclusive, os técnicos agrícolas e industriais, utilizando os "práticos" para as atividades industriais e agrícolas, cultivando variedades de cana pouco produtivas. A partir da Revolução de 1930, no entanto, esse quadro se modificou (Andrade, 1987, p. 160).

No Rio de Janeiro, na região de Campos, a implantação dos engenhos centrais provocou a desativação dos pequenos engenhos, cujos proprietários paulatinamente foram se tornando fornecedores de cana. Com a implantação das usinas, antigos senhores de engenho ou comerciantes ricos expandiram suas propriedades e incorporaram em definitivo os engenhos e engenhocas, fazendo surgir os latifúndios, apesar da resistência de numerosos pequenos proprietários fornecedores de cana (Andrade, 1994, p. 72).

Até a Primeira Guerra Mundial, o Norte Fluminense foi o segundo maior parque usineiro nacional, atrás apenas de Pernambuco, com 31 usinas em pleno funcionamento, em 1910. Em Campos, entre 1881 a 1920, 252 engenhos a vapor e 120 engenhocas foram reduzidos a 124 unidades, sendo 27 o número de usinas (Melo, 2009, p.210).

Nos outros estados não foi diferente. Em 1910, já existiam 187 usinas no país, sendo 12 em São Paulo, sete na Bahia e seis em Alagoas. 
Entre 1912 e 1918, 50\% da produção do açúcar brasileiro já era oriundo de usinas (Meira, 2010, p. 137).

O êxito geral das usinas subsidiadas na década de 1890, em contraste com o fracasso dos engenhos centrais apoiados pelo estado dez anos antes, pode ser atribuído a quatro fatores: melhor elaboração das leis, com menos aberturas para fraudes ou descumprimentos das normas; sistema de empréstimos diretos em títulos, em vez de garantia de retorno, o que foi mais eficiente, por obrigar o concessionário a levantar o capital necessário no mercado financeiro nacional; maior disposição de empréstimos da parte dos governos estaduais quando comparado com os governos central e provincial, por causa da autonomia da usina em adquirir a matéria-prima de seus próprios canaviais (Eisenberg, 1977, p. 131/132).

Parte dos engenhos centrais implantados, desde meados do século XIX, foi instalada a partir dos engenhos banguês, aos quais foram acopladas máquinas modernas, alterando pouco a pouco o seu sistema produtivo até a completa mecanização. Outra parte foi planejada e construída de uma só vez, com máquinas fabricadas por empresas francesas e inglesas, constituindo posteriormente as usinas, que assumiram o setor de derivados de cana-de-açúcar na primeira metade do século XX (Melo, 2009, p.119).

Devido à modernização promovida desde os engenhos centrais, ao crescimento da produção do Centro-Sul e ao declínio das exportações nordestinas, no período entre 1900 e 1914, a quantidade de açúcar disponível no país se ampliou bastante, atingindo o patamar de 230 milhões de toneladas anuais de açúcar, havendo dificuldades de sua absorção pelo mercado interno (Melo, 2009, p. 210; Meira, 2010, p. 139; IAA, 1972, p. 68).

Com um excedente que variava de 45 a 60 mil toneladas anuais, isto é, 20\% a $30 \%$ de cada safra, e o domínio do sistema de distribuição do açúcar por grupos comerciais de São Paulo e do Rio de Janeiro, cujas ações especulativas com os estoques de açúcar nordestino auferiam grandes lucros e reduziam ainda mais os preços (Melo, 2009, p. 210; Meira, 2010, p. 139; IAA, 1972, p. 68), os preços do açúcar caíram e uma nova crise se prenunciava. 
De fato, essa era uma crise de escala mundial. A eclosão da Primeira Guerra Mundial e a queda da produção de açúcar de beterraba europeu fez com que houvesse um forte aumento nos preços do açúcar no mercado mundial (Szmrecsányi, 1979, p. 166; Szmrecsányi, 1988) e, consequentemente, o estímulo para a expansão do cultivo da cana e produção de açúcar. Com o fim da guerra e o retorno da produção europeia de beterraba, o aumento da produtividade em todas as regiões açucareiras resultou em ampla oferta de açúcar de cana e na crise de superprodução (Szmrecsányi, 1979, p. 166; Szmrecsányi, 1988). No Brasil, a crise só não teve repercussões maiores porque o mosaico, doença que atacava a cana-de-açúcar, havia devastado os canaviais paulistas e fluminenses (Meira, 2010, p. 141).

Apesar da queda dos preços a partir do início da década de 1920, a produção brasileira de açúcar continuou a crescer, direcionada para o mercado interno. São Paulo e Rio de Janeiro, que produziam respectivamente, em 1925, 155.348 e 861.070 sacos de açúcar, em 1929, tinham uma produção de 1.113.417 e 2.102.019, ou seja, um aumento de $616 \%$ e 144\%. Em Pernambuco e Alagoas não era diferente. Suas produções, no ano de 1929, eram de 4.603.127 e 1.450.986 sacos de açúcar (Meira, 2010, p. 140; De Carli, 1940, p. 16 apud Szmrecsányi, 1979, p. 166). Dessa forma, devido ao excesso no mercado, o preço do açúcar foi decaindo mês após mês. No Rio de Janeiro, entre março e outubro de 1929, as cotações de açúcar cristal desceram de $76 \$ 500$ para $26 \$ 500$ (Melo, 1941, p. 10 apud Szmrecsányi, 1979, p. 166).

A situação era mais agravada pela especulação decorrente da comercialização do açúcar ser realizada por intermediários, grandes comerciantes varejistas e refinadores. Assim, não conseguindo escoar sua produção para o exterior, enfrentando um consumo interno em declínio decorrente da recessão econômica, a agroindústria canavieira encontrava-se quase arruinada durante a Grande Depressão Econômica nos anos de 1928-1930 (Szmrecsányi, 1979, p. 166/169; Szmrecsányi, 1988, p.?).

Desde 1924, a queda de preços do açúcar levou "os senhores de engenho a buscar apoio governamental, na forma de melhores preços para a cana e quotas fixas de produção" (Eisenberg, 1977, p. 132). Uma 
das formas de solucionar o problema foi apresentada, em 1928, no Plano Geral de Defesa do Açúcar, Aguardente e Álcool, que tinha como objetivo disciplinar a economia canavieira em bases cooperativistas. Contudo, ao invés de corrigir os problemas, as providências adotadas promoveram a melhoria das usinas, a ampliação da lavoura e melhor rendimento, aumentando ainda mais a produção (IAA, 1972, p. 67), o que agravou ainda mais a crise de superprodução.

Nessa época, a produção açucareira do Nordeste foi extremamente ameaçada também pela produção paulista. A crise da cafeicultura de 1929 fez com que vários cafeicultores vissem na cana-de-açúcar uma possibilidade para a minimização dos prejuízos decorrentes do café. Capitalizados e possuindo mão de obra disponível, eram favorecidos ainda pelo acesso mais fácil ao mercado consumidor nacional, devido à sua localização, e estavam dispostos a competir pelo mercado com os produtores de outros estados, o que poderia levar ao aniquilamento das antigas áreas açucareiras do Nordeste (Szmrecsányi, 1979, p. 169).

Tal fato não ocorreu, porque a Revolução de 1930 e a instauração do Estado Novo iniciaram "uma política intervencionista no plano econômico, que se refletiu, no caso do açúcar, na defesa, se não dos interesses, pelo menos da sobrevivência da indústria do Nordeste" (Singer, 1968, p. 234 apud Szmrecsányi, 1979, p. 169).

Deve-se destacar que a comercialização de outros produtos da cana, tais como a aguardente e o álcool, raramente correspondia a um quinto do valor das exportações no período imperial. A partir dos anos de 1890, no entanto, a demanda interna de aguardente cresceu, devido à imigração estrangeira e à abolição da escravatura. Além disso, a instalação das primeiras destilarias e o conhecimento das possibilidades de uso do álcool na iluminação pública, no início do século XX, fez com que a sua venda, em Pernambuco, em alguns momentos, ficasse próxima ao valor das exportações de açúcar (Eisenberg, 1977, p. 53). 


\subsection{A geografia canavieira na época dos engenhos centrais e o surgimento das usinas}

No período dos engenhos centrais e do início da produção usineira, a geografia canavieira se apresentou de forma diversa da época dos banguês. Pernambuco manteve a sua posição de maior produtor açucareiro, contudo a Bahia foi suplantada pelo Rio de Janeiro. A produção de Alagoas e Minas Gerais superou a de São Paulo, que assumiu na safra de 1929/1930 a $6^{\text {a }}$ posição.

Deve-se destacar que no caso da Bahia e de Minas Gerais, a maior parte da produção de açúcar se dava ainda nos engenhos banguês (Costa, 1969, p. 173; Canabrava, 1971, p. 110). Aliás, em 1920, havia apenas 233 usinas. Por outro lado, existiam 58.536 engenhos, que resistiam ao processo de expansão usineiro. É de fato notável a persistência dos banguês, paralelamente às usinas, com seu açúcar de pior qualidade, técnicas rudimentares e rentabilidade baixa, mas responsável por grande parte da produção. Na safra de 1929/1930, de 1.170 milhão de toneladas de açúcar produzido, 523 mil toneladas eram produzidas nos engenhos e 647 mil toneladas nas usinas, situação que iria mudar apenas a partir de 1950, época em que deixariam de existir por definitivo (Costa, 1969, p. 173; Canabrava, 1971, p. 110; Szmrecsányi, 1988).

A localização dos engenhos centrais e das usinas era ainda determinada, como ocorrera com os banguês, pela proximidade com os cursos d'água. As vias fluviais tinham grande importância, porque eram nelas que se obtinha a água necessária para o processamento da cana; que se transportava a matéria-prima e se escoavam os produtos até as ferrovias e portos; que, em alguns casos, se produzia energia hidroelétrica, como foi o caso do Engenho de Piracicaba; e era em suas águas que se eliminavam os efluentes das indústrias.

A proximidade com as vias férreas era importante, porque possuindo uma capacidade de moagem grande, os engenhos centrais e as usinas exigiam meios de transporte rápidos e com grande capacidade de carga (Melo, 2009, p. 296).

Da mesma forma, a cana-de-açúcar, para poder servir como matéria-prima a essas unidades produtivas modernas, também deveria ser cultivada em terrenos próximos a ferrovias ou em rios que possibilitas- 
sem o seu escoamento rápido até a indústria, lembrando-se que a cana cortada tinha o prazo máximo de 48 horas para realizar o seu processamento, após o qual perdia o rendimento sacarino. Assim, a cana de propriedades rurais não conectadas aos meios de transporte era inviabilizada para servir como matéria-prima, podendo, então, ser moída pelos banguês que se mantinham nas diversas províncias imperiais, posteriormente estados da República.

A expansão dos canaviais continuou a ser determinada quase que exclusivamente pelos fatores relevo, solo e clima, considerando-se o pequeno avanço tecnológico no setor agrícola da época. Nesse sentido, são exemplos o que ocorreu em São Paulo e Pernambuco. A expansão da fronteira canavieira em direção ao Planalto Ocidental Paulista se deu como consequência da expansão da rede ferroviária da Companhia Mogiana, mas possibilitada por nessa região haver um relevo com morros e colinas amplas, cobertos com Latossolos e Argissolos Vermelhos, adequados ao plantio da cana.

Dessa forma, um dos elementos importantes para a espacialização de engenhos, usinas e plantações de cana-de-açúcar nesse período foi a estrada de ferro. A construção de ferrovias foi realizada com o subsídio governamental, tendo dois objetivos principais: atender as demandas de transporte da oligarquia cafeeira e canavieira e, ao mesmo tempo, estabelecer-se como opção para investimentos tanto nacionais como estrangeiros. Para tanto, foi concedida a garantia de $7 \%$ de juros a sociedades anônimas, além da isenção de impostos sobre o material importado necessário à construção da ferrovia, como trilhos e máquinas (Penha, 2012, p. 194-195).

A primeira ferrovia a ser inaugurada no Brasil foi a Estrada de Ferro de Petrópolis, em 1854, na província do Rio de Janeiro, de propriedade governamental. A segunda foi construída em Pernambuco, na região açucareira mais importante, com subsídios imperiais e provinciais à empresa inglesa Recife and San Francisco Railway Company Limited, para a construção de uma linha de Recife até Palmares, concluída em 1862, com 125 quilômetros de extensão. O governo provincial estendeu essa linha até Garanhuns, sob o nome de Estrada de Ferro do Sul de Pernambuco, finalizada em 1887, e outro ramal até Alagoas, 
concluído em 1894. No início do século XX, essa linha já era responsável por cerca da metade da produção açucareira de Pernambuco (Eisenberg, 1977, p. 72).

$\mathrm{Na}$ mesma época, outra linha ferroviária foi construída em Pernambuco, nas porções Oeste e Noroeste, por meio de outra empresa inglesa, a Great Western Railway Company Limited, cuja linha principal ia de Recife até Limoeiro e um ramal secundário de Carpina até Timbaúba, posteriormente conectada até o Sul da Paraíba (Eisenberg, 1977, p. 72). Para transportar a cana das propriedades localizadas a Oeste, o governo provincial construiu a Estrada de Ferro Central de Pernambuco, atravessando a zona açucareira até Antônio Olinto e posteriormente até Sanharó (Eisenberg, 1977, p. 72).

No final da década de 1870, havia um total de 384 quilômetros de ferrovias ligando Recife às porções Norte, Sul e Oeste da Província, atravessando suas áreas açucareiras, complementadas por estradas de terra particulares, utilizadas por animais de carga, construídas para interligar as estações ferroviárias aos engenhos, como ocorreu em Escada e Jaboatão (Eisenberg, 1977, p. 72).

A expansão da malha ferroviária, reduzindo os custos de transporte para Recife, impeliu a implantação de engenhos nas áreas próximas dessas ferrovias. $\mathrm{Na}$ área atravessada pela Recife and San Francisco Railway, por exemplo, o número de engenhos quase dobrou após a sua operação, diferentemente do que ocorreu nas regiões que dependiam de navios costeiros para o escoamento do açúcar até Recife, como Ipojuca e Barreiros, ou em terrenos com extensão limitada ou mais intensamente ocupados pela população, como a Ilha de Itamaracá e os subúrbios de Recife (Eisenberg, 1977, p. 148).

Após 1885, três quartos de todo o açúcar enviado a Recife era transportado por trem, tendo sido praticamente eliminadas as caravanas de animais de carga, que transportavam menos de 5\%. Parte ainda era transportada por barcaças, mas em 1910, menos de um quinto era transportado por essa via de transporte (Eisenberg, 1977, p. 72).

Em São Paulo, a exportação do café pelo Porto de Santos atraiu também o capital inglês para investimento na construção da ferrovia São Paulo Railway, que ligou Jundiaí ao Porto de Santos, inaugurada 
em 1867, com 159 quilômetros, à qual foram conectadas todas as outras estradas de ferro paulistas, com exceção da ferrovia Vale do Paraíba, que partia da Estação Norte, atual Roosevelt (ABPF).

Como os ingleses não se interessaram no prolongamento da São Paulo Railway, fazendeiros, capitalistas e comerciantes paulistas utilizaram o capital acumulado com a cafeicultura e a cana-de-açúcar na criação de companhias ferroviárias que construíram a malha ferroviária utilizada pelos engenhos e usinas instaladas a partir do terceiro quartel do século XIX (Melo, 2009, p. 77). Até o final do século XIX, toda a Depressão Periférica e parte do Planalto Ocidental Paulista já se encontravam interligados ao Porto de Santos pelas Companhias de Estradas de Ferro Ituana, Sorocabana, Paulista e Mogiana, cujos trilhos alcançaram o rio Grande em 1888. Em 1877, a ferrovia Vale do Paraíba interligou a capital paulista à Corte Imperial (ABPF).

Portanto, entre 1875-1890, presenciamos uma fase intermediária entre o sistema produtivo arcaico do banguê, dominante até o final do século XIX, e os primórdios do sistema produtivo, que será mantido até o século XXI, desenvolvido pelas atuais usinas sucroenergéticas. Essa etapa intermediária se deu pelo processo de instalação dos engenhos centrais. $\mathrm{O}$ engenho central significou, de fato, uma ruptura entre as técnicas manufatureiras empregadas na produção de açúcar e derivados do Brasil colonial e imperial em direção àquelas que passaram a estar baseadas em novos inventos e processos técnico-científicos desenvolvidos a partir da Revolução Industrial.

Apesar de ambas as unidades produtivas terem como objetivos a busca por uma maior produtividade, qualidade e lucro (Viana, 1981, p.13) por meio da introdução de novas tecnologias, é importante atentar para a diferença em relação à forma de aquisição da matéria-prima, o que, na verdade, caracterizou um sistema e outro de produção. Enquanto as companhias concessionárias do engenho central não podiam possuir terras próprias para o cultivo da cana-de-açúcar, a qual deveria, obrigatoriamente, ser adquirida de terceiros, no caso das usinas, permitia-se a posse de lavouras próprias e ao mesmo tempo a moagem de cana de outros lavradores. Assim, apesar de tanto o engenho central como a usina estarem baseadas na aplicação de novos procedimentos 
e tecnologias industriais, no âmbito produtivo, o engenho central se caracterizou conceitualmente pela separação entre as etapas agrícola e industrial, enquanto no caso da usina essa separação não existia.

Dessa forma, um dos elementos diferenciadores dessa fase intermediária é de fato o emprego de novas tecnologias utilizadas, sobretudo no setor industrial.

\subsection{Inovações provenientes do engenho central}

Apesar do insucesso dos engenhos centrais, sobretudo em relação ao dispêndio de dinheiro público, eles promoveram o aprimoramento dos transportes e de tecnologias no chão de fábrica açucareiro brasileiro. Mesmo no cultivo da cana alguns progressos se fizeram sentir.

Os novos métodos de fabricação do açúcar e outros derivados (álcool e aguardente), adotados a partir dos engenhos centrais, infundiram uma maior racionalização do trabalho, favorecendo e consolidando a passagem do trabalho escravo para o livre (Costa, 1969, p. 172).

Basicamente, o processo de produção açucareiro a partir de 1875 utilizava como força motriz o vapor, mas em alguns engenhos também era utilizada a energia hidroelétrica oriunda de pequenas centrais hidroelétricas localizadas nos rios, como foi o caso do Engenho Central de Piracicaba, que possuía turbinas hidráulicas de 120 cavalos movidas por uma queda d'água existente no rio Piracicaba (Melo, 2009, p. 271).

Uma planta industrial completa do Engenho Central demandava um terreno de aproximadamente $2.000 \mathrm{~m}^{2}$, consistindo de um grande edifício de alvenaria, próximo a algum rio e ferrovia. À margem do rio construía-se um cais, para o desembarque das canas. Havia também uma balança para pesagem da matéria-prima, que, por meio de guindastes, era colocada em tramways e conduzida até as moendas a vapor (Melo, 2009, p. 268/269). As moendas eram de três rolos horizontais, sendo que cada conjunto de três rolos recebia a denominação de terno. As primeiras moendas eram de madeira, depois foram revestidas por uma chapa metálica (Fernandes, 1971, p. 120).

Da moenda, o caldo seguia para a calação e decantação. Após o processo de decantação, o caldo era filtrado e seguia para a evaporação e cozimento, feito a vácuo. A massa cozida era resfriada e conduzida 
às turbinas centrífugas, por meio de caminho férreo (Melo, 2009, p. 268/269). Para se ter uma ideia da capacidade produtiva desses engenhos, uma indústria plenamente equipada produzia cerca de 10 toneladas diárias de açúcar predominantemente branco. O Engenho Central de Porto Feliz, por exemplo, que tinha uma capacidade produtiva pequena, produzia aproximadamente de 7 a 9 toneladas de açúcar em um período de 10 horas e meia. Nos banguês do início do século XIX, um engenho médio produzia de 1 a 1,5 toneladas de açúcar/dia, predominantemente mascavo (Melo, 2009, p. 268/269; Eisenberg, 1977, p. 64).

Para a produção do vapor necessário, utilizava-se a lenha, o que levou alguns engenhos a enfrentar problemas por causa do grande consumo para o funcionamento das caldeiras, como já havia acontecido com os banguês em relação às fornalhas. Na moagem de 1891, por exemplo, os Engenhos Centrais de Capivari, Lorena e Porto Feliz consumiram, respectivamente, 24,5\%, 37,6\% e 48,8\% de lenha em relação ao peso da cana (Melo, 2009, p. 282). O reaproveitamento do bagaço como combustível era necessário, contudo necessitava ser seco. Em 1882, foi divulgada na Revista Agrícola do Imperial Instituto Fluminense o forno Godillot, que possibilitava a queima do bagaço verde saído da moenda, sendo o Central de Barcellos (RJ) o primeiro engenho a utilizá-lo no Brasil (Imperial Instituto Fluminense, 1882).

Apesar do processo de obtenção do açúcar ter sofrido uma mudança profunda, as etapas de produção eram as mesmas do antigo engenho banguê, tendo o processo de mecanização ocorrido cronologicamente, no mesmo sentido do fluxo produtivo: moenda, casa de caldeiras, purga (Fraginals, 1988, p. 297).

Em relação à obtenção da aguardente, houve também modificações quando foram implantados os engenhos centrais. Nas casas de purgar dos engenhos banguês, um álcool de baixa graduação já era produzido. Nas formas cônicas onde era depositada a massa de açúcar, pingava um caldo grosso por um orifício no seu fundo para purgar o açúcar. Era o melaço. Misturado à agua, formava-se uma garapa, a qual depois era colocada em cochos para fermentação natural. Essa mistura açucarada, o mosto, era aquecida em fogo num alambique. Os vapores alcoólicos saíam pela parte superior do alambique e se condensavam ao 
passar por uma serpentina mergulhada em tanque d'água, ocorrendo a destilação (Figura 12), resultando no álcool, chamado aguardente ${ }^{9 .}$

Figura 12. Produção de aguardente em engenhos banguês.

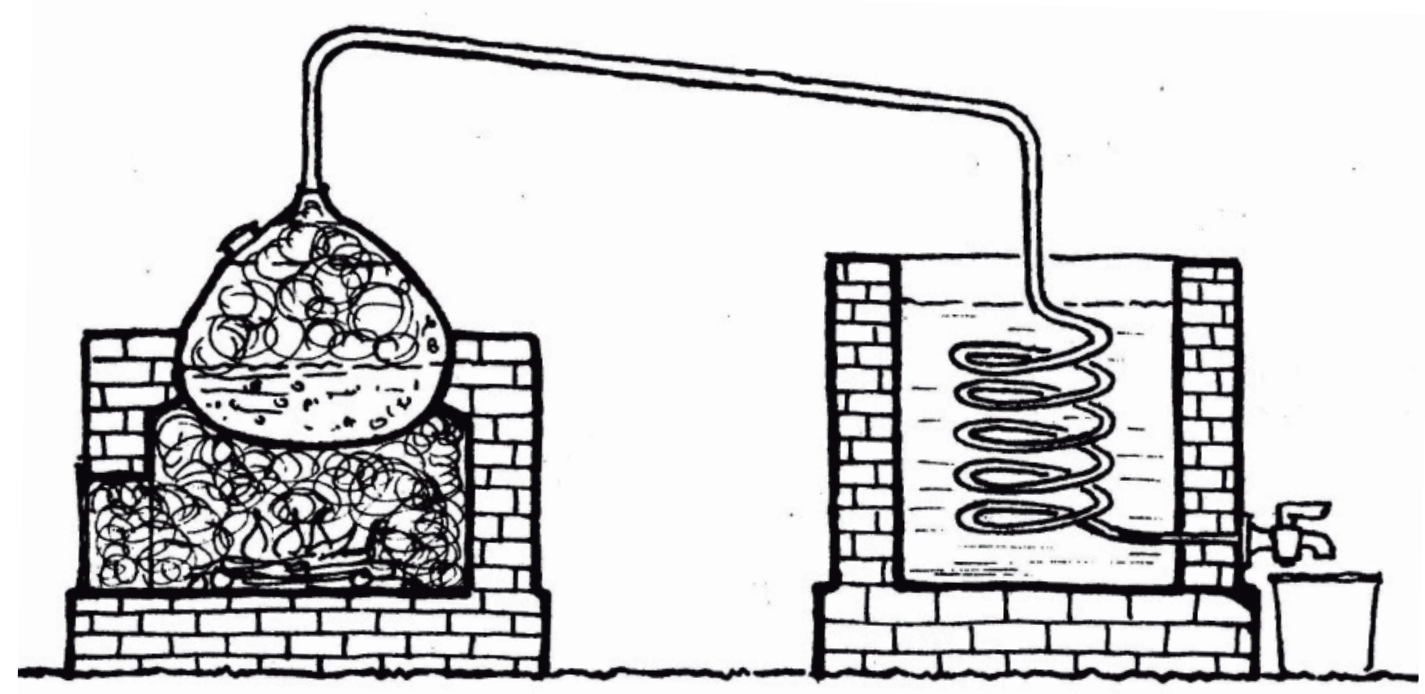

Fonte: Fernandes, 1971, p. 151. Adaptado pelos autores, 2016.

Dessa forma, "apenas os vapores mais voláteis eram desprendidos e condensados, razão da baixa graduação do produto, tais as impurezas contidas" (Fernandes, 1971, p. 50). Por essa razão, nos antigos engenhos banguês não se produzia álcool.

O processo de obtenção do mosto nos engenhos centrais se dava também a partir do melaço estocado em tanques, onde era separada a garapa, fermentada com o uso de leveduras em reservatórios fechados, denominados de dornas. Em alguns engenhos, como os de Capivari e Piracicaba, foram instaladas colunas de destilação e retificação, que

9 De acordo com a Instrução Normativa $\mathrm{n}^{0}$ 13/2005, do Ministério da Agricultura, Pecuária e Abastecimento (Mapa), aguardente "é a bebida com graduação alcoólica de $38 \%$ vol (trinta e oito por cento em volume) a $54 \%$ vol (cinquenta e quatro por cento em volume) a $20^{\circ} \mathrm{C}$ (vinte graus Celsius), obtida do destilado alcoólico simples de cana-deaçúcar ou pela destilação do mosto fermentado do caldo de cana-de-açúcar, podendo ser adicionada de açúcares até $6 \mathrm{~g} / \mathrm{l}$ (seis gramas por litro)". A cachaça é a denominação típica e exclusiva da aguardente de cana produzida no Brasil, com graduação alcoólica de 38 \% vol (trinta e oito por cento em volume) a $48 \%$ vol (quarenta e oito por cento em volume) a $20^{\circ} \mathrm{C}$ (vinte graus Celsius), obtida pela destilação do mosto fermentado do caldo de canade-açúcar com características sensoriais peculiares, podendo ser adicionada de açúcares até $6 \mathrm{~g} / \mathrm{l}$ (seis gramas por litro)." (MAPA, 2005, p. 1). 
permitiram que a destilação se desse de forma gradativa, iniciando-se pelos produtos mais voláteis contidos no mosto, e a retificação pela graduação do produto, possibilitando a produção de 15 a 20 hl de álcool/ dia (Fernandes, 1971, p. 157; Melo, 2009, p. 271).

Todo esse processo de mudança tecnológica na produção dos derivados da cana-de-açúcar demandou a modificação dos meios de transporte, pois a capacidade produtiva dos engenhos centrais e das usinas exigia um deslocamento mais rápido, já que a cana cortada devia chegar ao máximo até 48 horas para a moagem, demandando maior capacidade de carga, o que não era possível com a utilização de bois. Dessa forma, os carros de boi ficaram restritos aos transbordos das ferrovias e dos portos fluviais próximos (Melo, 2009, p. 296) e serviram para o uso dos engenhos banguês e dos meio-aparelhos ainda existentes.

A partir da década de 1870, as primeiras ferrovias privadas, construídas ou não pela demanda das indústrias canavieiras, passaram a ser utilizadas para transportar mais rapidamente quantidades maiores de cana. Embora algumas dessas primeiras ferrovias fossem à tração animal e com trilhos portáteis, como em Pernambuco, mais tarde se tornariam permanentes. Além das redes das companhias férreas, praticamente todos os engenhos centrais e usinas montaram pequenas ferrovias a vapor, algumas com subsídios do governo, como foi o caso das usinas pernambucanas de Cachoeira Lisa e Bom Fim, conectando não só os canaviais aos engenhos, como também transportando cargas públicas e passageiros de Recife ao rio São Francisco (Eisenberg, 1977, p. 60/61).

No setor agrícola, algumas iniciativas progressistas foram colocadas em ação. Em meados do século XIX, foi fundado o Imperial Instituto Fluminense de Agricultura (1860), subvencionado anualmente pela Coroa e vinculado ao Ministério da Agricultura, Comércio e Obras Públicas. Seus membros, influenciados pelo cientificismo do século XIX, propunham a separação da agricultura das demais áreas do conhecimento, o que seria a base para o Decreto Imperial sobre os engenhos centrais. Além disso, por meio da Revista Agrícola, foram divulgadas experiências com sementes, técnicas de beneficiamento do solo, melhoria de raças de animais, alternativas à escassez da mão de 
obra, dentre outras questões, conhecimentos esses que se difundiram em algumas regiões do país (Penha, 2012, p. 77).

Os agricultores continuaram a não utilizar fertilizantes, exceto em momentos críticos, como em Pernambuco, em 1879, quando a gomose infestou os canaviais. A Sociedade Auxiliadora da Agricultura de Pernambuco (Saap), diante dessa situação, "importou guano, nitrato de sódio e superfosfato para fortalecer os solos pobres, acusados de causar a enfermidade. Mas logo que o perigo passou esta prática foi esquecida" (Eisenberg, 1977, p. 61).

Em 1892, houve o relato de uma experiência com hibridização seletiva da cana, que o proprietário do Engenho Cachoeirinha, em Escada, Pernambuco, havia realizado, além de ter criado a variedade Manteiga (Eisenberg, 1977, p. 60). Mas o que se verifica até o fim do Império (1888) e em toda a Primeira República (1930) são apenas algumas ações muito pontuais de modernização do cultivo da cana-de-açúcar. Mantinha-se, contudo, a estrutura administrativa e agrícola muito similar a dos antigos engenhos. O usineiro, sobretudo nordestino, continuava a administrar a sua unidade produtiva de modo patriarcal, quase sempre dispensando os técnicos com formação acadêmica e preferindo a contratação dos chamados "práticos", que adquiriam seu conhecimento de forma empírica, no trabalho diário. Muitas usinas, até a década de 1950, não tinham em seus quadros agrônomos e químicos (Andrade, 1997, p. 160).

Apenas nas décadas de 1920 e 1930, em São Paulo, começou a haver uma atenção mais generalizada em relação à melhoria do rendimento agrícola. A partir daí foram oferecidos cursos para a formação de técnicos agrícolas e de engenheiros agrônomos e desenvolvidas pesquisas em instituições organizadas para tal fim (Andrade, 1994, p. $56 / 57)$.

Com a apresentação de sinais de degenerescência e queda na produtividade das variedades tradicionais cultivadas, caiana e cristalina, novas variedades de sementes começaram a ser selecionadas e introduzidas, oriundas da Índia (Co), da Indonésia (POJ) e dos Estados Unidos (CP). Pragas como o mosaico passaram a ser combatidas de forma mais incisiva e fertilizantes passaram a ser utilizados. Todo esse processo, 
após algumas décadas, conduziria São Paulo à liderança nacional na produção canavieira (Andrade, 1994, p. 56/57).

No período de introdução dos engenhos centrais, a abolição da escravatura impactou de forma diferente as províncias açucareiras. As sociedades rurais escravistas foram paulatinamente substituídas por uma sociedade que Melo (1975) denominou, no caso do Nordeste, de tutelada, a qual continuaria a estar sob o comando da mesma classe possuidora dos meios de produção, mas agora com o trabalho escravo sendo substituído pelo trabalho livre.

Muitos dos trabalhadores livres eram antigos escravos que permaneceram nas zonas açucareiras. De acordo com os censos de 18721890, houve um declínio da população da zona da mata, o que pode indicar a emigração da população, inclusive de ex-escravos, da zona do açúcar para o agreste e o sertão, mas a maioria permaneceu na zona da mata porque não havia nenhum outro lugar para ir. As áreas urbanas já apresentavam excedente populacional, o que já era um problema social desde o começo do século XIX. No interior, já se sentia a pressão demográfica sobre as terras do agreste e caatinga. Para as regiões cafeeiras, o custo do transporte era impeditivo (Eisenberg, 1977, p. 202)

Os trabalhadores livres do agreste e do sertão migraram para a Zona da Mata e substituíram também os escravos das plantações desde a década de 1870 . O retorno da produção de algodão norte-americana encerrou a produção algodoeira nas regiões mais interioranas e a ocorrência de grandes secas, no final dos anos de 1870, acabaram por compelir esses trabalhadores para o Leste em busca de empregos nos canaviais. Na época de colheita, $45 \%$ da mão de obra eram formados por esses migrantes sazonais oriundos do sertão, para onde regressavam com a chuva (Eisenberg, 1977, p. 202).

Havia ainda a parceria (arrendamento), existente desde o século XVI, e que no início do século XIX contabilizava cerca de dois a três rendeiros por engenho. O rendeiro geralmente era branco, possuía de seis a sete escravos, sendo que em 1878 era responsável por 50\% do açúcar exportado pela província pernambucana (Eisenberg, 1977, p. 209).

O latifundiário às vezes fornecia as mudas para a primeira safra e permitia que o parceiro cultivasse produtos alimentícios para seus fa- 
miliares e escravos. O lavrador tinha de plantar, cultivar, cortar e transportar a cana para o engenho na época designada pelo proprietário. Tinha de pagar o dono da terra com metade da própria safra de cana ou do açúcar fabricado, e também com a metade do melaço, de toda a aguardente e de todos os produtos residuais (Eisenberg, 1977, p. 207209).

No processo de transição do engenho à usina, os agricultores menores continuaram a ser chamados de parceiros e os maiores passaram a ser denominados de rendeiros. Os parceiros pagavam o arrendamento com metade da cana cultivada e os rendeiros com percentagens menores e decrescentes, conforme a sua produção aumentava, mas com a obrigação de fornecimento de certa quantidade de cana ao proprietário da terra, arcando ainda com o ônus financeiro, caso não fosse cumprida essa obrigação. Com a introdução dos engenhos centrais e usinas, esse sistema foi ampliado, abrangendo também os senhores de engenho, que passaram a ser denominados de fornecedores, cujas safras muitas vezes eram financiadas pelos usineiros, criando uma relação de dependência semelhante àquela com os rendeiros e parceiros (Eisenberg, 1977, p. 212).

Em relação à imigração de estrangeiros, alguns comerciantes de Recife a promoviam esporadicamente para melhorar a mão de obra, no entanto com poucos resultados, muito diferente do que ocorria no Centro-Sul. Entre as décadas de 1850 a 1870, algumas ações nesse sentido foram realizadas, mas o fracasso contínuo desestimulou novos planos até 1888, quando a iminência da abolição reavivou a preocupação com a falta de mão de obra e o governo imperial propôs-se a pagar as passagens transatlânticas dos imigrantes. As autoridades provinciais adquiriram o Engenho Suassuna, em Jaboatão, e a fazenda Jaqueira nas proximidades de Recife para a formação de colônias de imigrantes (Eisenberg, 1977, p. 216).

Mas nos primeiros anos da República, os governos nacional e provincial recusaram-se a manter o auxílio à imigração. Assim, após problemas com alimentação, pagamento e diferença de costumes, na década de 1890 muitos dos imigrantes voltaram para a Europa ou se dirigiram para o Rio de Janeiro (Eisenberg, 1977, p. 216). Outras ini- 
ciativas nesse sentido ocorreram no Nordeste açucareiro, mas todas se mostraram infrutíferas.

Algumas possíveis explicações podem ser apresentadas para o mau êxito das imigrações em Pernambuco. Primeiramente, a situação econômica da província pernambucana dificultava o processo imigratório. Entre 1890 e 1910, anos de imigração europeia mais intensa para o Brasil, a exportação do café do Centro-Sul produziu uma renda média anual de 400 a 500 mil contos de réis, enquanto a do açúcar menos de 50 mil, o que permitiu ao governo paulista o dispêndio de 1.000 contos anuais para o subsídio da imigração, enquanto em Pernambuco o subsídio era pequeno ou inexistente. Do mesmo modo, no auge da produção cafeeira, os trabalhadores rurais recebiam $1 \$ 000$ a $1 \$ 400$ por dia, enquanto em Pernambuco não mais que $\$ 800$ (Eisenberg, 1977, p. 222).

Outra questão importante que desfavoreceu a imigração para a província nordestina foi a escassez de terras públicas na Zona da Mata, a região açucareira melhor servida por transportes públicos. As terras devolutas estavam encravadas nas de domínio particular e ocupavam pequenas extensões, diferentemente, por exemplo, do Rio Grande do Sul, de Santa Catarina e do Paraná. Em São Paulo, as terras também eram escassas, mas os imigrantes eram contratados como trabalhadores assalariados e tinham a expectativa de, após acumulado certo capital, comprar a sua própria terra no Oeste paulista.

Nesse quesito, a compra de terras por parte dos imigrantes, é outra questão que deve ter sido levada em consideração. O custo do estabelecimento da cultura cafeeira era muito diferente daquele demandado pela produção açucareira. Para a produção do café, havia a necessidade de "lavar, secar, limpar, classificar, catar e ensacar, operações meramente manuais ou mecânicas. Mesmo se mecanizadas, a colheita, o beneficiamento e a classificação custariam no máximo um ou dois contos." (Eisenberg, 1977, p. 222). Já para a produção do açúcar havia a exigência de "cortar e moer sua cana, e de transformá-la quimicamente em açúcar e álcool. Um investimento em máquinas era inevitável e a modernização custava no mínimo 50 contos" (Eisenberg, 1977, p. 222).

Outro problema eram as características climáticas muito diferentes das europeias, sobretudo relacionadas à temperatura. Grande par- 
te da zona açucareira pernambucana fica na zona equatorial, onde as temperaturas no verão são em média de $27,2^{\circ} \mathrm{C}$ e no inverno de $23,8^{\circ} \mathrm{C}$ (Eisenberg, 1977, p. 218), muito diferentes do clima europeu. Claro que só o clima não era razão suficiente para a falta de imigrantes, mas associado às questões econômicas, tornava-se um fator também importante a ser considerado.

\subsection{Impactos socioambientais dos primórdios da indústria açucareira}

A implantação dos engenhos centrais com sua moderna tecnologia aumentou sobremaneira a capacidade produtiva da indústria de derivados de cana, provocando impactos ambientais com intensidade até então não verificada. Impulsionando a expansão dos canaviais para áreas ainda não ocupadas intensamente pela agricultura, ainda no período imperial, em várias das províncias brasileiras, esses impactos iriam abranger outros espaços, além da zona costeira.

Embora a expansão tenha se dado em áreas com características geográficas diferentes daquelas do período colonial, quando os canaviais ficavam limitados às áreas litorâneas, devido à quantidade e à qualidade de dados disponíveis para a discussão dos impactos socioambientais da economia canavieira nesse tempo histórico, serão utilizados dois exemplos das duas mais importantes regiões açucareiras dessa época: Pernambuco, no Nordeste, e São Paulo, no Sudeste.

Até o século XIX, a cultura canavieira pernambucana se desenvolveu predominantemente nas planícies fluviais, e sua extensão era determinada pela largura e características do curso d'água, maior em rios mais largos e de pouca energia, menor em rios estreitos e/ou com muita energia. Os Argissolos silicosos, profundos, bem drenados, presentes nessas áreas, eram especialmente adequados ao rápido desenvolvimento da cana (Perruci, 1978, p. 100), e por isso eram preferidos, em detrimento de outras áreas.

Pouco a pouco, no entanto, com a maior demanda de matéria-prima pelos engenhos centrais e, posteriormente, pelas usinas, e com as áreas de planície já totalmente ocupadas pela cultura canavieira ou aglomerados humanos, o cultivo da cana se expandiu para o interior, 
na Zona da Mata, até o limite com o agreste. A interiorização da cultura canavieira pernambucana foi fruto das conexões com as Estradas de Ferro do Sul e Central de Pernambuco, mas só foi possível graças as características do relevo colinoso, cobertos por Latossolos VermelhoAmarelos, que foram amplamente desmatados (Eisenberg, 1977, p. 61).

Em São Paulo, até o final do século XIX, a cultura canavieira havia se restringido às áreas litorâneas e à Depressão Periférica, onde a produção havia atingido grande envergadura no final da década de 1840. A partir do final dos anos de 1890, entretanto, o cultivo da canade-açúcar se fez sentir no Planalto Ocidental Paulista, com a instalação dos engenhos de Araraquara, Sertãozinho e Franca, fazendo com que, além da Floresta Pluvial Atlântica, áreas de campo cerrado que cobriam as colinas amplas dessa região começassem a sentir os efeitos da implantação dos canaviais.

Contrapondo-se ao que aconteceu nas indústrias açucareiras, o praticamente inexistente avanço das técnicas agrícolas na cultura canavieira fazia com que persistissem as práticas coloniais de retirada da vegetação e queimadas para a limpeza total do terreno, e o uso do pousio após o uso da terra pelo cultivo.

A madeira retirada dessas matas agora apresentava duas finalidades principais. Grande parte era utilizada para alimentar as caldeiras, que produziam o vapor necessário para a operação das indústrias, além das fornalhas dos banguês ainda existentes. Outra parte servia para a construção das bitolas das linhas férreas e das dornas para a fermentação do caldo que produzia álcool e aguardente. Em Lorena, por exemplo, vigas de ipê foram utilizadas nas ferrovias, enquanto o tapinhoã e o carvalho foram empregados na construção das dornas (Melo, 2009, p. 283).

Outro aspecto importante a ser destacado é que a partir da implantação dos engenhos centrais, a quantidade de vinhaça produzida, que com certeza já ocorria nos engenhos banguês, se tornou bem mais intensa. A vinhaça, ou vinhoto, é um resíduo da destilação do caldo de cana-de-açúcar fermentado, resultante do processo de produção tanto da cachaça como do álcool. É composta por substâncias orgânicas e minerais (com predominância de sais de sódio e potássio), possui elevada 
temperatura, DQO (Demanda Química de Oxigênio), DBO (Demanda Biológica de Oxigênio) e pH baixo. Quando eliminada nos rios, a acidez desaparece e as substâncias orgânicas, que são nitrogenadas, entram em fermentação, eliminando um gás de odor pútrido. Sem tratamento, na época, a eliminação da vinhaça nos rios, além de ter causado odor característico intenso, provavelmente deve ter provocado a morte da ictiofauna, impedido a pesca e a dessedentação dos animais.

Atualmente, para cada litro de cachaça ou álcool, são gerados uma proporção de 6 a 8 litros (Oliveira, 2005, p. 43), ou 13 litros de vinhaça, respectivamente. Considerando-se que "Na década de 1910, a produção alcançou 30 milhões de litros de álcool e 100 milhões de litros de aguardente" (Meira, 2010, p. 178), chega-se a uma estimativa total de cerca de 3 bilhões de litros de vinhaça produzidos nesse período.

Como observado anteriormente, uma das características de localização do sítio dos engenhos centrais e usinas era a proximidade dos rios. Infere-se, portanto, que a vinhaça produzida foi eliminada muito provavelmente nesses cursos d'água, o que é ratificado pelo que ocorreu no Engenho Central de Lorena, onde havia "um encanamento de esgoto de tubos de barro, com $1.900 \mathrm{~m}$ de comprimento para a remoção de resíduos lançados no rio Paraíba” (Melo, 2009, p. 272), ou em Pernambuco, onde o relato do engenheiro fiscal do Império faz menção ao problema que os fornecedores de cana enfrentavam com os engenhos quando "resíduos da destilaria poluíam os rios e matavam o gado"(Eisenberg, 1977, 117).

Outro resíduo originado no processo industrial é a torta de filtro, proveniente da filtração do caldo extraído das moendas. É um composto $85 \%$ orgânico, possuindo também diversos metais: alumínio, manganês, zinco e ferro. É rico em cálcio, nitrogênio e potássio, com composições variáveis dependendo da variedade da cana e da sua maturação, e apresenta elevada Demanda Bioquímica de Oxigênio (DBO). Atualmente, para cada tonelada de cana-de-açúcar moída, são produzidos de $25 \mathrm{~kg}$ de torta de filtro. Na década de 1910, o Brasil exportou aproximadamente 129.622 toneladas de açúcar (Eisenberg, 1977, p. 260).

Embora parte do açúcar produzido não tenha sido contabilizada, por ser comercializado no mercado interno, e que uma parcela do 
açúcar exportado tenha sido fabricado em engenhos rudimentares, sem grande produção desse resíduo, considerando que atualmente o rendimento de açúcar é de $138 \mathrm{~kg}$ de açúcar/tonelada de cana, podemos inferir que nos anos de 1910 tenham sido gerados pelo menos 1 bilhão e meio de quilos de torta de filtro.

Em função de sua característica orgânica e composição, a torta de filtro pode causar sérios problemas ambientais se carreada em direção aos corpos d'água, o que provavelmente deve ter ocorrido, tendo em vista o grau de desconhecimento na época acerca de seus impactos e da falta de construção de depósitos adequados para a sua disposição.

Até o início do século XIX, "o principal meio de transporte terrestre era o carro de boi, de madeira, com duas caixas, pesando de meia a três quartos de tonelada e puxado por seis ou doze bois" (Eisenberg, 1977, p. 71). Os carros de boi foram substituídos, em meados do século, pelas caravanas de cavalos e mulas, que carregavam individualmente sacos com cerca de 60 a $80 \mathrm{~kg}$ de açúcar. As mulas eram preferidas em relação aos bois, pois eram mais rápidas, e em relação ao transporte marinho, porque evitavam a umidade fluvial das barcaças que percorriam os rios transportando o açúcar e estragando-o (Eisenberg, 1977, p. 71).

$\mathrm{O}$ advento dos engenhos centrais e das usinas trouxeram consigo a necessidade do uso de meios de transporte mais ágeis e rápidos, o que foi resolvido com a construção das ferrovias para essa finalidade, como em Pernambuco, ou pelo uso das linhas férreas construídas para o transporte do café, como em São Paulo, provocando o desemprego dos muladeiros. Em Pernambuco, cerca de 20 mil muladeiros ficaram sem emprego (Eisenberg, 1977, p. 73).

Outro impacto de grande magnitude que afetou várias províncias açucareiras foi a incorporação dos antigos banguês pelas usinas. Durante a entressafra, os usineiros, mais capitalizados, financiavam os fornecedores, os quais muitas vezes não conseguiam saldar suas dívidas, sendo obrigados a vender suas propriedades à usina, que assim ampliava seu patrimônio fundiário.

Apesar dos poucos dados disponíveis, tendo em vista inclusive a questão socioambiental não ser uma preocupação do final do século 
XIX e do início do século XX, salvo poucos estudos descritivos sobre a flora e a fauna brasileiras e alguns registros econômicos e relatos sobre o modo de vida daqueles que lidavam com a cultura canavieira, é certo que a introdução dos engenhos centrais e das usinas provocaram grandes modificações no sistema produtivo e, consequentemente, impactos nos meios físico, biótico e socioeconômico.

Podemos considerar, por outro lado, que o desenvolvimento de novas tecnologias proporcionou, por exemplo, a invenção do forno Godillot, o qual, não por preocupações genuinamente ambientais, levou a uma menor demanda de lenha e, portanto, a um menor corte de árvores.

Por fim, não podemos deixar de mencionar o grande impacto social que a implantação dessas grandes unidades industriais modernas trouxe sobre a estrutura fundiária, com a crescente incorporação das propriedades de pequenos e médios agricultores pelos grandes capitais usineiros e sua conversão em funcionários das usinas ou a condução à migração para os centros urbanos.

Dessa forma, os impactos socioambientais do setor canavieiro ocorrentes nas primeiras décadas do século XX seriam apenas um prenúncio do que se estabeleceria nos períodos futuros. Impactos em grande parte adversos, de grande magnitude. Alguns cíclicos, como o lançamento de vinhaça nos corpos d'água durante a época de safra, outros irreversíveis, como os possíveis desaparecimentos de espécies da fauna e flora endêmicas em rios e florestas. 


\section{Surge o NOVO POLO CANAVIEIRO}

\subsection{O planejamento estatal do setor sucroalcooleiro}

brasileiro se inicia

Desde o final do século XIX, a economia açucareira se caracterizou por ciclos de escassez e de superprodução, e, consequentemente, por flutuações de preços crescentes e decrescentes. Sobretudo a partir do século XX, a oferta açucareira sempre foi superior à demanda, tendo em vista que as usinas eram instaladas com uma capacidade de produção adequada às perspectivas de consumo futuras. Os ciclos de escassez ficavam circunscritos a momentos circunstanciais, tais como a Primeira e a Segunda Guerras Mundiais, quando a comercialização de açúcar de outros países produtores ficava impedida de ter um fluxo normal.

No Brasil, embora a intervenção governamental no setor canavieiro tenha se dado também no período colonial e imperial, foi apenas a partir dos anos de 1930 que "O planejamento, entendido como processo de intervenção racional do Estado nas atividades econômicas, foi institucionalizado na agroindústria canavieira" (Szmrecsányi, 1979, p. 163), passando a efetivamente conduzir o processo evolutivo do setor.

Sua gênese encontra-se localizada na grande depressão econômica mundial de 1929, quando os problemas do setor canavieiro não conseguiram mais ser debelados com medidas pontuais ligadas apenas às políticas monetárias e/ou fiscais (Szmrecsányi, 1979, p. 163; Melo, 1975, p. 230). 
A agroindústria canavieira brasileira encontrava-se nessa época em situação bastante frágil, com uma superprodução de açúcar, na safra de 1929/1930, de aproximadamente 1 milhão e 200 mil toneladas, não conseguindo ser comercializada nem no Exterior nem no mercado interno, devido à recessão geral econômica (Szmrecsányi, 1988).

Com o fim da República Velha e a instauração do novo regime, centralizador, sob o comando de Getúlio Vargas, em outubro de 1930, passaram a ser adotadas medidas na tentativa de solucionar o problema da superprodução açucareira por meio da limitação da produção de açúcar, da proibição da instalação de novas usinas e engenhos e da promoção e aceleração da industrialização do álcool (Szmrecsányi, 1979, p. 170; Andrade, 1977, p. 39).

O álcool era produzido do melaço (álcool residual) nas usinas de açúcar, ou diretamente da cana-de-açúcar (álcool direto) nas destilarias autônomas ou anexas às usinas. As destilarias anexas eram aquelas implantadas junto com as usinas de açúcar. As destilarias autônomas eram unidades independentes das usinas de açúcar, podendo ser derivadas de antigos alambiques.

Até o início da década de 1930, o álcool produzido era do tipo residual, destinado quase que exclusivamente ao consumo doméstico ou às nascentes indústrias químicas e farmacêuticas. Em algumas zonas açucareiras, era também já utilizado em veículos, como tratores e caminhões das próprias usinas (Melo, 1941, p. 47 apud Szmrecsányi, 1979, p. 170-171).

Para ser utilizado como combustível em motores à explosão, o álcool precisava ser desidratado, ou seja, transformado em álcool anidro, isento de água, e com graduação superior a $99,5^{\circ}$, processo possível apenas em grandes destilarias providas com o maquinário necessário (Szmrecsányi, 1979, p. 171). Como a maior parte das usinas era destituída desse tipo de equipamento, a maioria dos usineiros eliminava o melaço nos rios, vales e canais próximos (Melo, 1941, p. 47 apud Szmrecsányi, 1979, p. 171).

Para incentivar o aproveitamento desse subproduto e aumentar as divisas do país, o governo federal instituiu o Decreto $n^{0}$ 19.717/1931, que determinava a comprovação, pelo importador de gasolina, da adi- 
ção de $5 \%$ de álcool e que os automóveis da União, dos estados e municípios deveriam, sempre que possível, utilizar o álcool, pelo menos na proporção de $10 \%$.

Além disso, o Decreto isentava de impostos de importação todo o aparelhamento necessário à fabricação do álcool anidro nas destilarias. Por meio de outras resoluções, na mesma época (1931-32), também foi criada a Comissão de Estudos sobre o Álcool Motor (Ceam) e concedida autorização ao Ministério da Agricultura para assinar contratos com entidades particulares para a implantação de destilarias de álcool anidro (Szmrecsányi, 1979, p. 175).

Em relação à produção açucareira, foram instituídos estoques reguladores e cotas de produção e criada a Comissão de Defesa de Produção do Açúcar (CPDA) para a execução de tais medidas (Szmrecsányi, 1979, p. 173-174).

A constituição da CPDA, com a participação de membros do governo federal e de delegados dos estados de Pernambuco, Alagoas, Sergipe, Bahia, Rio de Janeiro e São Paulo, iniciou uma nova fase de intervenção estatal na agroindústria açucareira. Com base em análises estatísticas e comerciais trimestrais da produção açucareira e dos preços praticados nos mercados internos, a CPDA formulou o Plano de Defesa da Produção do Açúcar, adquirindo os excedentes da produção para, em parte, serem exportados a preços irrisórios, e, em parte, formarem os estoques reguladores, normalizando possíveis preços especulativos do mercado nacional (Szmrecsányi, 1979, p. 173-174).

Até 1933, no entanto, essas regulamentações não tiveram a efetividade esperada. A produção de açúcar continuou ainda muito maior que a demanda interna e o incentivo à produção direta de álcool anidro era uma solução adequada, mas só em médio prazo. Nesse contexto, foi criado o Instituto de Açúcar e Álcool (IAA), resultado da fusão da CPDA e da Ceam, que passou a executar a intervenção governamental na economia canavieira, iniciando-se, a partir de então, de fato, o processo de planejamento governamental no setor sucroalcooleiro brasileiro (Szmrecsányi, 1979, p. 176-177).

As duas atribuições básicas do IAA eram a regulação do mercado de açúcar e o fomento da produção de álcool anidro, estritamente vin- 
culados, haja vista que, em certa medida, o controle do mercado açucareiro dependia do envio da cana-de-açúcar excedente para a produção direta de álcool (IAA, 1972, p. 8 apud Szmrecsányi, 1979, p. 181). Após 1938, entretanto, vários dispositivos legais ampliaram os poderes do IAA, cujas decisões passaram a ser independentes da apreciação judicial (Szmrecsányi, 1979, p. 197).

Dentre outras ações, a intervenção na economia alcooleira procurou resolver ou amenizar as disputas regionais entre o Nordeste e o Centro-Sul. Para isso, previu a instalação de grandes destilarias centrais; o auxílio financeiro a cooperativas, sindicatos, empresas ou produtores que desejassem instalar ou adaptar destilarias para a fabricação de álcool anidro; a fixação de cotas de entrega de álcool por parte das usinas para ser beneficiada ou vendida aos importadores de gasolina; o controle dos preços de venda dos combustíveis fabricados à base de álcool; a instalação e manutenção de bombas de álcool-motor para venda ao público; e a assistência técnica aos proprietários de destilarias de álcool anidro (Brasil, 1933, Art. $4^{\circ}$ ).

As cotas produtivas de cada usina foram estabelecidas tendo como base o serviço estatístico - já iniciado pela CPDA e que continuou a ser realizado pelo IAA - sobre o consumo, os preços do açúcar e do álcool nacionais, a média produtiva anual do último quinquênio das usinas, as estimativas das safras e os estoques de açúcar do país em maio e setembro (Szmrecsányi, 1979, p. 184-185).

A porcentagem dos eventuais aumentos ou reduções de cotas deveria ser igual para todas as usinas localizadas em determinado estado, e se houvesse um decréscimo de produção em alguma usina, poderia ser compensado pela produção das outras usinas, desde que estivessem no mesmo estado e não excedessem o limite geral de produção estadual. A produção que ultrapassasse a cota autorizada era confiscada sem indenização (Szmrecsányi, 1979, p. 185).

Passava também a ser proibida a montagem de novas usinas, engenhos e banguês para produção de açúcar, rapadura ou aguardente em todo o território nacional sem prévia consulta ao IAA (Brasil, 1933; Brasil, 1939a, Art. 14).

Dando sequência à proposta da CPDA, a intervenção direta do 
IAA no mercado açucareiro, para o restabelecimento do equilíbrio quantitativo entre produção e consumo, se deu por meio da retirada da quantidade de açúcar julgada como necessária, tendo como base os levantamentos estatísticos realizados e o seu encaminhamento para exportação, transformação em álcool ou para qualquer outro destino considerado como adequado (Brasil, 1933, Art. 30, alíneas "d" e "e",).

Em 1935, foram estipulados, em resoluções específicas do IAA, os limites de produção de açúcar dos estados onde estavam localizadas as usinas (Tabela 5). Verifica-se que, na distribuição espacial da produção açucareira, Pernambuco mantém a sua preponderância sobre os demais estados. Contudo, São Paulo surge como o $2^{\circ}$ produtor de açúcar de usina do país, sobrepujando a produção fluminense. Além disso, observa-se que a região Norte/Nordeste, com 62,8\% da produção, mantém a sua posição de destaque frente à região Centro-Sul, com 37,2\% (Szmrecsányi, 1979, p. 193).

Tabela 5. Limites de produção de açúcar de usina e número de usinas no Brasil em 1935/1936.

\begin{tabular}{|c|c|c|c|c|}
\hline \multirow[t]{2}{*}{ Estados produtores } & \multicolumn{2}{|c|}{ Limites de produção } & \multirow[t]{2}{*}{ Data das Resoluções do IAA } & \multirow[t]{2}{*}{$\mathrm{N}^{0}$ de usinas } \\
\hline & Sacos de $60 \mathrm{~kg}$ & $\%$ & & \\
\hline $\mathrm{PE}$ & 4.450 .193 & 37,6 & 11/o3/1936 & 62 \\
\hline SP & 2.067 .863 & 17,4 & 11/07/1935 & 32 \\
\hline RJ & 2.000 .137 & 16,9 & 11/07/1935 & 27 \\
\hline $\mathrm{AL}$ & 1.301 .928 & 11 & 23/12/1935 & 23 \\
\hline SE & 721.519 & 6,1 & 01/10/1935 & 80 \\
\hline $\mathrm{BA}$ & 685.101 & 5,8 & 16/o9/1935 & 16 \\
\hline MG & 339.599 & 2,9 & 09/07/1935 & 21 \\
\hline $\mathrm{PB}$ & 225.912 & 1,9 & 24/09/1935 & 07 \\
\hline PA, MA, CE, RN & 54.433 & 0,4 & 24/o9/1935 & 11 \\
\hline TOTAL & 11.846 .695 & 100 & & 279 \\
\hline
\end{tabular}

Fonte: DE CARLI, 1940, p. 73 apud SZMRECSÁNYI, 1979, p. 194; ANDRADE, 1987, p. 162. Org.: dos autores, 2015. 
O alto número de usinas no estado de Sergipe foi reflexo da implantação de modernos engenhos turbinados nesse estado desde 1872, bem como dos investimentos de senhores de engenho e empresários dos setores comercial e industrial. No entanto, apesar do número elevado, apresentavam pequena produção (6,1\% do total), equivalente à dos engenhos banguês (Andrade, 1977, p. 102/167).

Segundo as projeções do IAA, portanto, em 1935, a produção de açúcar de usina superaria os 11,8 milhões de sacos, sem contar a produção dos engenhos e banguês, responsáveis por mais de 40\% do açúcar consumido no país. Com a perspectiva da safra de 1935/1936 ser ainda maior do que a anterior, o IAA baixou outra resolução limitando o período de safra a 90 dias (Szmrecsányi, 1979, p. 107/195).

Em relação à instalação das destilarias centrais para a fabricação do álcool anidro, foram implantadas, no final da década de 1930, três, localizadas próximas aos principais centros de distribuição da gasolina importada: as destilarias centrais de Campos, no estado do Rio de Janeiro; do Cabo, em Pernambuco; e de Ponte Nova, em Minas Gerais, sendo utilizado como matéria-prima o melaço não aproveitado pelas usinas localizadas nas áreas de influência dessas destilarias, bem como o excedente da produção de açúcar (Szmrecsányi, 1979, p. 191-192/205).

A instalação dessas destilarias, com capacidade produtiva de 60 mil l/dia para as duas primeiras e $20 \mathrm{mil} \mathrm{l/dia} \mathrm{para} \mathrm{a} \mathrm{terceira,} \mathrm{acabou}$ provocando uma forte concentração espacial da produção alcooleira, tendo em vista que mais de $92 \%$ da produção de álcool acabaram por ficar localizados nesses três estados (Szmrecsányi, 1979, p. 191-192/205).

Finalmente, após a adoção dessas medidas, o mercado açucareiro se viu estabilizado. Em contraposição, o conflito entre usineiros e senhores de engenho se viu acirrado. De fato, desde o início dos trabalhos do IAA, ou seja, desde o final de 1933, as medidas adotadas para a estabilização do mercado açucareiro contribuíram para a expansão dos cultivos próprios das usinas e para a sua autossuficiência (Szmrecsányi, 1979, p. 196).

Mas além do cultivo pelas próprias indústrias, nas zonas usineiras a cana era cultivada por agricultores vinculados econômica e juri- 
dicamente às usinas, denominados de fornecedores (Melo, 1975, p. 47). Quando havia a queda do preço do açúcar devido a uma boa safra ou pela redução do consumo, os prejuízos eram divididos entre o usineiro e os plantadores da cana. Se, por outro lado, houvesse o aumento do preço do açúcar, devido à safra não ter sido boa ou pela expansão da demanda, os usineiros controlavam os estoques de açúcar, propiciando grande lucratividade, o que não ocorria com o fornecedor, impossibilitado de estocar a cana colhida, extremamente perecível (Ramos, 1983, p. 107).

Os litígios entre usineiros e fornecedores de cana-de-açúcar eram preocupantes nos estados açucareiros, sobretudo em Pernambuco, onde os senhores de engenho procuravam se defender dos baixos preços pagos pelos usineiros, com greves e até com a retirada dos trilhos das ferrovias que transportavam a cana até as usinas (Ramos, 1983, p. 113/114).

Os conflitos no Nordeste só foram amainados com o estabelecimento do DL $\mathrm{n}^{0}$ 1.669/1939, quando ficou determinado que $70 \%$ da matéria-prima das usinas deveriam ser providas por fornecedores, lavradores e colonos, e só os outros 30\% pelos plantios próprios da usina, exceto quando não houvesse fornecedores.

Do mesmo modo, foram fixadas cotas de produção de açúcar para cada estado, divididas em três partes: 50\% para as usinas de menor produção, 30\% para as médias e 20\% para as maiores. O estabelecimento das categorias, menor, média e maior, era realizado conforme o estado e a capacidade produtiva da usina (Brasil, 1939b).

Em virtude da grande resistência dos produtores e da falta de aplicabilidade imediata das cotas produtivas, instituídas em 1933, elas foram reafirmadas com a publicação de uma lista de engenhos e usinas com os respectivos limites de produção (Brasil, 1939c). Com base nas cotas de produção, passaram a ser elaborados pelo IAA, anualmente, os Planos de Defesa da Safra ou Planos de Safra (Szmrecsányi, 1979, p. 184/197). Em 1938, ficava estabelecida a diferenciação entre engenho, fábrica que não possuía turbina ou vácuo, e usina, fábrica que detinha esses equipamentos (Brasil, 1938).

Nos estados cuja produção era inferior a 100 mil sacos anuais e com canaviais sem possibilidade de utilização devido à inexistência de 
fábricas próximas ou pela dificuldade de escoamento, novas usinas e engenhos foram autorizados a ser instalados (Brasil, 1939d; Szmrecsányi, 1979, p. 198).

Essas regulações acabaram resultando na promulgação, em 1941, do Estatuto da Lavoura Canavieira - ELC pelo Decreto Lei $\mathrm{n}^{\mathrm{o}}$ 3.855/1941. O ELC pode ser considerado como um marco na evolução do intervencionismo estatal do setor e uma manifestação completa da orientação populista da política de Getúlio Vargas (Szmrecsányi, 1979, p. 201).

O principal objetivo do Estatuto da Lavoura Canavieira foi o disciplinamento das relações comerciais entre usineiros e fornecedores por meio da regulação das condições de fornecimento e de absorção da cana pelas usinas, a restrição da produção canavieira pelas usinas e a distribuição entre usineiros e fornecedores dos encargos ou vantagens das mudanças nas cotas de produção, mediante a instituição de cotas de fornecimento (Szmrecsányi, 1979, p. 201).

O ELC definiu o lavrador como aquele que cultivava terras próprias ou alheias, fornecendo cana a uma mesma usina durante três ou mais safras consecutivas, compreendendo tanto parceiros quanto arrendatários e lavradores, sujeitos ao risco agrícola (Brasil, 1941, Art. 1º).

As usinas passaram a ser obrigadas a receber de seus fornecedores a quantidade de cana pré-fixada pelo IAA, sendo que a usina ou destilaria que se recusasse seria obrigada a ressarcir o dano causado (Brasil, 1941, Arts. 17 e 39). O ELC dispunha ainda que para a fabricação da cota de açúcar, as usinas cujo limite fosse superior a 30.000 sacos poderiam utilizar canas próprias até o máximo de $60 \%$ do seu limite, sendo que os $40 \%$ restantes deveriam ser oriundos de fornecedores; para aquelas que tinham um limite entre 15.000 a 30.000, a porcentagem era calculada sobre o volume excedente aos 15.000 sacos; e para aquelas que tinham limite inferior a 15.00o, o dispositivo não se aplicava (Brasil, 1941, Art. 48).

Estabeleceu-se também que as comissões competentes fixariam o salário mínimo dos trabalhadores no canavial e na indústria de açúcar e álcool, bem como um regime de contratos padronizados, onde eram previstas certas garantias aos lavradores (Melo, 1975, p. 20-242). 
No Nordeste, o ELC foi bem aceito pelos fornecedores, mas rejeitado pelos usineiros, que o encaravam como um atentado contra o direito de propriedade. No Rio de Janeiro, onde os conflitos já eram menores, não houve grande resistência. Em São Paulo, a promulgação do ELC fez com que os antigos colonos fossem transformados em fornecedores, transferindo-se para eles o ônus da produção da matéria-prima, enquanto o capital, antes empregado para o custeio dos colonos, foi liberado para outros investimentos (Andrade, 1994, p. 191).

Em relação às exportações, desde 1937, a comercialização mundial de açúcar brasileiro estava baseada no Acordo Internacional de Londres, sendo atribuído ao Brasil um limite de 60 mil toneladas anuais. Embora a eclosão da II Guerra Mundial tenha provocado a suspensão automática desse acordo e possibilitado a exportação livre de açúcar para a Europa, ao mesmo tempo fez com que as exportações ficassem praticamente suspensas, assim como as importações de bens intermediários, como o petróleo, devido aos riscos de transporte em alto mar, por causa de ataques dos submarinos nazistas. Pelos mesmos motivos, o comércio de cabotagem, que realizava as trocas comerciais entre o Norte e o Sul do Brasil, foi paralisado (Szmrecsányi, 1979, p. 201/204/265).

O desenvolvimento da IIGM e a total desorganização do transporte marítimo obrigou o governo a submeter o planejamento do setor açucareiro aos interesses dos estados do Centro-Sul, que na época detinham as cotas produtivas de açúcar mais baixas, para conseguirem atender o próprio consumo e os estados vizinhos. Dessa forma, São Paulo, que tinha grande demanda de consumo, tornou-se também o fornecedor de açúcar de Goiás, Mato Grosso e Paraná (Andrade, 1977, p. 40).

A partir de 1943, o IAA começou a determinar preços fixos para o açúcar, adotando o preço disponibilizado nos portos exportadores do Nordeste. Nos demais estados, com exceção do Rio de Janeiro, que também era exportador de açúcar, os preços eram automaticamente determinados pelo preço que chegasse o produto nordestino a esses destinos. Consequentemente, as empresas de comercialização do açúcar localizadas no Centro-Sul passaram a se beneficiar do sobrepreço decorrente (Melo, 1975, p. 234) 
Assim, a II GM, diferentemente do que ocorrera com a I GM, não provocou o aumento da demanda externa do açúcar brasileiro, mas influiu decisivamente nos caminhos doravante percorridos pela agroindústria canavieira. Ao engendrar dificuldades para a importação de bens como o petróleo, na época quase que totalmente oriundo do exterior, deslocou o interesse da indústria brasileira para a produção do álcool. Ao prejudicar o comércio de cabotagem e, por conseguinte, o abastecimento de açúcar na área meridiana do país, determinou o início da mudança na geografia canavieira, com o deslocamento do polo da indústria sucroalcooleira brasileira de Pernambuco para São Paulo, o que seria consolidado na década de 1950. Cada vez mais, a partir de então, uma das principais características da economia relacionada ao setor canavieiro será colocada em relevo - a repartição espacial. A divisão geográfica entre dois grupos regionais, Norte/Nordeste e CentroSul, e as suas idiossincrasias socioeconômicas serão cada vez mais realçadas e diferenciadas.

\subsection{São Paulo: o novo polo da indústria canavieira}

Desde a instalação da primeira destilaria autônoma de álcool anidro em Piracicaba, em 1933, a produção desse derivado de cana evoluiu. No final dos anos de 1930, encontravam-se em operação no país 35 destilarias de álcool anidro (Andrade, 1994, p. 163), subindo esse número, em 1941, para 44, com capacidade de 638 mil l/dia e produção anual de 76,6 milhões de litros (Szmrecsányi, 1979, p. 205). Situação resultante em grande parte das normas editadas pelo IAA (Quadro 1), intensificadas no período da II Guerra Mundial.

De fato, a IIGM afetou grandemente a economia e a sociedade brasileiras. A rede ferroviária nordestina, instalada no final do século XIX, foi sucateada e a navegação de cabotagem interrompida. Por outro lado, o sistema rodoviário se expandiu em várias partes do país, primeiramente com a implantação de estradas carroçáveis e depois de rodovias, o que facilitou a obtenção do açúcar branco pelos habitantes do interior. Ao final dos anos de 1950, isso levou à preferência e predominância do açúcar branco em detrimento do consumo da rapadura (Andrade, 1994, p. 40). 


\section{Quadro 1. Principais normas editadas pelo governo central concernentes ao setor alcooleiro (1933-1945).}

\begin{tabular}{|c|c|}
\hline Normas & Pontos principais \\
\hline $\begin{array}{l}\text { Decreto } \\
22.789 / 1933\end{array}$ & Criação do IAA \\
\hline $\begin{array}{l}\text { Decreto } \\
22.981 / 1933\end{array}$ & $\begin{array}{l}\text { Início do programa para instalação de três destilarias centrais para a fabricação } \\
\text { de álcool anidro, com subsídio de 50\% do IAA }\end{array}$ \\
\hline $\begin{array}{l}\text { Decreto } \\
23.664 / 1933\end{array}$ & Regulamentação do fomento do consumo de álcool carburante e suas misturas \\
\hline $\begin{array}{l}\text { Decreto } \\
23.837 / 1934\end{array}$ & $\begin{array}{l}\text { Reiteração da obrigatoriedade do uso de álcool-motor em carros públicos e de- } \\
\text { terminação da redução de tarifas rodoviárias para o transporte de álcool. }\end{array}$ \\
\hline Lei n⿳0 432/1937 & $\begin{array}{l}\text { Concessão de isenção dos direitos de importação para tonéis e vasilhames des- } \\
\text { tinados ao transporte e armazenamento do álcool anidro. }\end{array}$ \\
\hline $\mathrm{DL} \mathrm{n}^{0} 737 / 1938$ & $\begin{array}{l}\text { Estabelecimento da obrigatoriedade da adição de álcool anidro à gasolina pro- } \\
\text { duzida no Brasil ( } 5 \%) \text {, e não apenas à importada. }\end{array}$ \\
\hline $\begin{array}{l}\text { Resolução IAA } \\
\text { oo3/1939 }\end{array}$ & $\begin{array}{l}\text { Disposição sobre a apresentação de projetos que visassem a obtenção do finan- } \\
\text { ciamento do IAA para a montagem ou ampliação de destilarias particulares. }\end{array}$ \\
\hline $\begin{array}{l}\text { Resolução IAA } \\
\text { de } 21 / 02 / 1941\end{array}$ & Elevação do teor mínimo de mistura do álcool anidro à gasolina para 20\%. \\
\hline DL $3.855 / 1941$ & Promulgação do Estatuto da Lavoura Canavieira \\
\hline $\begin{array}{l}\mathrm{DL} \mathrm{n}^{\mathrm{o}} \\
3 \cdot 755 / 1941\end{array}$ & Criação da Comissão Nacional de Combustíveis e Lubrificantes \\
\hline $\begin{array}{l}\text { DL n } \\
4 \cdot 382 / 1942\end{array}$ & $\begin{array}{l}\text { Delegação ao IAA do poder de fixação de cotas e preços para o álcool produzido } \\
\text { por usinas e destilarias autônomas do país para fins carburantes. }\end{array}$ \\
\hline $\begin{array}{l}\text { Resolução IAA } \\
31 / 1942\end{array}$ & $\begin{array}{l}\text { Destinação do máximo de matéria-prima disponível para a produção de álcool, } \\
\text { considerando o Plano de Safra 1942/1943. } \\
\text { Estabelecimento do total da quantidade de açúcar de usina para consumo e de } \\
\text { estoques equivalente a 15,2 milhões de sacos de } 60 \mathrm{~kg} \text { e da entrega ao IAA dos } \\
\text { limites excedentes para transformação em álcool. } \\
\text { Determinação da possibilidade de requisição do melaço e do álcool potável em } \\
\text { usinas para desidratação. }\end{array}$ \\
\hline $\begin{array}{l}\text { DL no } \\
4.461 / 1942\end{array}$ & $\begin{array}{l}\text { Disposição sobre o controle por parte do IAA da comercialização de todos os } \\
\text { tipos de álcool produzidos no país. }\end{array}$ \\
\hline
\end{tabular}


continuação da p. 124

\begin{tabular}{|c|c|}
\hline Normas & Pontos principais \\
\hline $\begin{array}{l}\text { Resolução IAA } \\
\text { 034/1942 }\end{array}$ & $\begin{array}{l}\text { Estabelecimento do Plano de Desenvolvimento do Álcool, com normas para } \\
\text { assegurar a máxima produção de álcool-motor e produção suficiente de álcool } \\
\text { hidratado para outros fins. }\end{array}$ \\
\hline $\begin{array}{l}\text { Resolução IAA } \\
39 / 1942\end{array}$ & $\begin{array}{l}\text { Estabelecimento do Plano de Controle da Produção do Álcool com normas sobre } \\
\text { os preços e bonificações a serem pagas aos produtores na safra de 1942/1943. } \\
\text { Instituição da taxa de } \$ 500 \text { (quinhentos réis) por litro de álcool vendido a ser } \\
\text { recolhido à Caixa do Álcool. } \\
\text { Proibição da fabricação de álcool potável pelas destilarias de álcool anidro e do } \\
\text { desdobramento do álcool anidro em aguardente. }\end{array}$ \\
\hline $\begin{array}{l}\mathrm{DL} \mathrm{n}{ }^{\circ} \\
4 \cdot 722 / 1942\end{array}$ & $\begin{array}{l}\text { Declaração da indústria alcooleira como de “interesse nacional”. } \\
\text { Estabelecimento, pelo prazo de quatro anos, a partir da safra de 1943/1944, de } \\
\text { garantias de preços mínimos para o álcool e para a cana excedente das próprias } \\
\text { usinas, dos fornecedores, dos produtores agrícolas que não possuíam cotas de } \\
\text { fornecimento e para outros produtos agrícolas que pudessem ser empregados } \\
\text { na produção do álcool. }\end{array}$ \\
\hline $\begin{array}{l}\text { Portaria CME* } \\
\text { oo8/1942 }\end{array}$ & $\begin{array}{l}\text { Autorização para as indústrias químicas montarem destilarias autônomas de } \\
\text { álcool para uso na própria indústria. }\end{array}$ \\
\hline $\begin{array}{l}\text { Resolução IAA } \\
n^{0} 65 / 1943\end{array}$ & $\begin{array}{l}\text { Aprovação do Plano de Requisição da Aguardente da safra 1942/1943 para } \\
\text { transformação em álcool. }\end{array}$ \\
\hline DL 5.998/1943 & $\begin{array}{l}\text { Disposição sobre a distribuição de álcool de todos os tipos, fixando multas para } \\
\text { o álcool transportado sem autorização do IAA }\end{array}$ \\
\hline $\begin{array}{l}\text { Resolução IAA } \\
105 / 1945\end{array}$ & $\begin{array}{l}\text { Condicionamento da concessão de cotas para a montagem de novas usinas açu- } \\
\text { careiras mediante a instalação de destilarias de álcool anidro anexas, com capa- } \\
\text { cidade de } 15 \text { litros de álcool para cada saco de } 60 \mathrm{~kg} \text {. }\end{array}$ \\
\hline
\end{tabular}

*CME - Coordenação de Mobilização Econômica

Fonte: Tamás SZMRECSÁNYI, 1979, p. 205-209; Julieta Rico, 2013, p. 94,95. Org.: dos autores, 2015.

Desde 1942, a interrupção do comércio de cabotagem de áreas do Nordeste para o Centro-Sul provocou a edição de outra série de normas (Quadro 2), na tentativa de impedir o racionamento de açúcar no Sul do país, o que reativou a tendência, interrompida durante a década de 1930, de deslocamento da hegemonia açucareira nordestina para o Centro-Sul (Szmrecsányi, 1979, p. 211; Andrade, 1994, p. 191).

Passou-se a permitir a implantação de pequenas usinas e destilarias, as quais foram substituindo, no mercado regional, a produção açucareira do Norte/Nordeste (Szmrecsányi, 1979, p. 211; Andrade, 1994, p. 191). 
Quadro 2. Normas editadas pelo governo central visando à promoção da produção açucareira (1942-1945).

\begin{tabular}{|c|c|}
\hline Normas & Pontos principais \\
\hline $\begin{array}{l}\text { Portaria CME } 17 / 1942 \\
\text { (Regulamentada pela } \\
\text { Portaria IAA 060/1943) }\end{array}$ & $\begin{array}{l}\text { Liberação do regime de cotas de produção de açúcar e da montagem de } \\
\text { novas usinas }\end{array}$ \\
\hline $\begin{array}{l}\text { Resolução CFCE* } \\
\text { 10/12/1942 } \\
\text { (Regulamentada pelo } \\
\text { DL 6.389/1944) }\end{array}$ & $\begin{array}{l}\text { Recomendação da suspensão, enquanto houvesse os efeitos da II Guerra } \\
\text { Mundial, das medidas restritivas à produção de rapadura e de açúcar } \\
\text { bruto nos engenhos em atividade. } \\
\text { Liberação da instalação de novas fábricas de rapadura. }\end{array}$ \\
\hline $\begin{array}{l}\text { Portaria } \mathrm{CME}^{* * *} \\
49 / 1943\end{array}$ & $\begin{array}{l}\text { Autorização da instalação de novos engenhos, com capacidade até } 400 \\
\text { sacos/ano, em estados insuficientemente abastecidos por produção de } \\
\text { açúcar. }\end{array}$ \\
\hline $\begin{array}{l}\text { Resolução IAA } \\
\text { 069/1943 }\end{array}$ & $\begin{array}{l}\text { Adoção de medidas para a produção de açúcar nas usinas do Centro-Sul } \\
\text { de parcelas que não podiam ser fornecidas pelos produtores do Nordeste } \\
\text { devido às dificuldades de transporte durante a II GM. }\end{array}$ \\
\hline Resolução IAA 79/1944 & $\begin{array}{l}\text { Aumento para 20\% dos limites estaduais de produção de açúcar. } \\
\text { Manutenção da liberação, para a safra 1944/1945, da produção de açú- } \\
\text { car dos engenhos turbinados e dos banguês. }\end{array}$ \\
\hline $\begin{array}{l}\text { Resolução IAA } \\
103 / 1945 \\
\text { Regulamentada pela } \\
\text { res. IAA 105/45 }\end{array}$ & $\begin{array}{l}\text { Criação de cotas para a montagem de novas usinas nos estados cujo } \\
\text { nível de consumo ou cuja distância dos centros produtores gerasse de- } \\
\text { manda insatisfeita. As cotas corresponderiam a uma produção anual de } \\
700 \text { mil sacos/ano atribuídas, por concorrência pública, a empresas do } \\
\text { Amazonas, do Piaú, do Ceará, do Rio Grande do Norte, da Bahia, de } \\
\text { Minas Gerais, de São Paulo, do Paraná e do Rio Grande do Sul. }\end{array}$ \\
\hline Resolução IAA 111/1945 & $\begin{array}{l}\text { Reajuste das cotas produtivas de açúcar das usinas com limites inferio- } \\
\text { res a } 20 \text { mil sacos anuais, distribuídos entre os estados de Piauí, Per- } \\
\text { nambuco, Alagoas, Sergipe, Bahia, Rio de Janeiro, Minas Gerais e São } \\
\text { Paulo, atribuindo-se a cada estado uma cota adicional de } 100 \text { mil sacos. }\end{array}$ \\
\hline $\begin{array}{l}\text { Resolução IAA } \\
116 / 1945\end{array}$ & $\begin{array}{l}\text { Permissão da instalação de turbinas nos engenhos banguês cadastrados } \\
\text { no IAA e detentores de cota produtiva de açúcar igual ou superior a } 500 \\
\text { sacos/ano. Autorização da instalação de cozedores a vácuo nos engenhos } \\
\text { turbinados e da transformação dos engenhos com cotas superiores a } \\
\text { 3.0oo sacos/ano em usinas. Concessão de cotas de açúcar às destilarias } \\
\text { autônomas que produzissem } 120 \text { mil litros de álcool direto nas safras de } \\
\text { 1933/1944 e 1944/1945 }\end{array}$ \\
\hline
\end{tabular}

Fonte: SZMRECSÁNYI, 1979, p. 210-213. Org.: dos autores, 2015.

Assim, após o final da IIGM e, sobretudo, do fim do Estado Novo, a tendência do aumento da produção e do deslocamento do eixo canavieiro tornou-se mais intenso. No governo de Eurico Gaspar Dutra (1946-1951), abriu-se espaço para a expansão do setor canavieiro paulista (Ramos, 1983, p. 131), sendo criadas condições, por meio de decreto-lei e de resoluções do IAA, para a subordinação dos limites 
das cotas produtivas estaduais às demandas de consumo das populações dos estados e não mais proporcionalmente ao consumo total de açúcar do país (Szmrecsányi, 1979, p. 215; Brasil, 1946).

Nos estados industrializados, como São Paulo, o consumo de açúcar durante e após a II GM havia aumentado muito devido ao crescimento da população e aos processos de urbanização e industrialização, bem como à expansão do setor alimentício, que o utilizava como insumo (Szmrecsányi, 1979, p. 218). Assim, com as cotas de produção sendo determinadas em função do consumo, o estado de São Paulo se viu beneficiado, passando os seus limites de produção de açúcar para a casa dos 5 milhões de sacos.

Tabela 6. Reajuste das cotas de produção de açúcar de usina dos seis maiores estados produtores (Resolução IAA 125/1946).

\begin{tabular}{c|c|c}
\hline ESTADOS PRODUTORES & $\begin{array}{c}\text { LIMITES } \\
(1944-1945)\end{array}$ & COTAS REAJUSTADAS \\
\hline Pernambuco & $5 \cdot 978.590$ & 6.490 .529 \\
\hline São Paulo & 2.792 .291 & 5.000 .000 \\
\hline Rio de Janeiro & 2.670 .990 & 3.735 .512 \\
\hline Alagoas & 1.957 .749 & 2.319 .924 \\
\hline Sergipe & 961.421 & 1.212 .983 \\
\hline Minas Gerais & 586.593 & 1.256 .560 \\
\hline
\end{tabular}

Fonte: SZMRECSÁNYI, 1979, p. 217. Org.: dos Autores, 2019.

Nesse momento, a distribuição espacial da produção açucareira começou a se alterar. Na safra de 1944/1945, os estados do CentroSul passaram a produzir $39,9 \%$ contra $46,8 \%$ de sacos de açúcar no Nordeste. A participação de São Paulo passou de 17,6\% para 22,2\%; e de PE, de 37,3\% para 28,9\% (Tabela 6) (Szmrecsányi, 1979, p. 214-215). Em relação ao número de usinas, em 1946, no Norte/Nordeste, estavam cadastradas 147 usinas; e no Centro-Sul, 116; em 1950, esses números passaram para 161 e 163, respectivamente (PINA, 1972, p. 39).

Outra mudança importante, nessa época, foi em relação às cotas de cana-de-açúcar de fornecedores e próprias da usina, que passaram a 
ser em proporções iguais, permitindo-se, inclusive, à usina a ampliação desse limite, acima dos 50\%, caso houvesse incapacidade produtiva dos fornecedores ${ }^{10}$ (Szmrecsányi, 1979, p. 216).

Mas muito mais importante do que essas mudanças introduzidas por via normativa para o deslocamento do centro canavieiro para o Centro-Sul foram as características vantajosas apresentadas pela agroindústria canavieira paulista: "maior capacidade financeira, mercado em posição vantajosa, um parque industrial moderno com eficientes instalações e condições agrícolas favoráveis" (PINA, 1972, p. 41) fizeram os custos médios de produção agrícola e industrial serem muito menores do que os do Nordeste (Szmrecsányi, 1979, p. 218).

A conservação e a modernização do setor industrial nordestino se viu interrompida durante o período de guerra, fazendo com que várias usinas se tornassem obsoletas. Diferentemente, São Paulo implantou uma indústria metalúrgica pesada, que forneceu as máquinas necessárias às usinas paulistas e, posteriormente, às nordestinas também (Andrade, 1994, p. 109).

Nesse contexto, a lavoura canavieira se expandiu em direção ao Oeste paulista, nas áreas antes cafeeiras de Araraquara e Ribeirão Preto e na região de Araçatuba, anteriormente ocupada pela pecuária, propagando-se no sentido do Vale do Rio Paranapanema, atingindo o Norte do Paraná (Andrade, 1994, p. 170/171).

Até então, a produção paulista era direcionada ao consumo interno, o que provocou, inclusive, no final do século XIX, o surgimento de grande número de refinarias. Em 1910, foi criada a Companhia União de Refinadores, que passou a adquirir usinas em operação, a instalar novas unidades de produção e a estimular a absorção das refinarias menores pelas maiores ou por aquelas que melhor estivessem localizadas (Gnaccarini, p. 19/20, apud Andrade, 1994, p. 168).

Nesse processo, o capital comercial e industrial controlou praticamente toda a produção de açúcar do estado, a tal ponto que no pe-

\footnotetext{
${ }^{10}$ Lembrar que pelo Estatuto da Lavoura Canavieira (1939) havia ficado determinado que $70 \%$ da matéria-prima deveria ser provida por fornecedores, lavradores e colonos, e só os restantes $30 \%$ pela produção agrícola da própria usina, exceto quando não houvesse fornecedores.
} 
ríodo 1930-1946, três dos quatro maiores produtores paulistas eram a Société des Sucrèries Brésiliennes, o Grupo Morganti e o Grupo Matarazzo (Ramos, 1983, p. 74). A Société, possivelmente ligada ao grupo metalúrgico francês Fives Lille, era fabricante de máquinas para usinas de açúcar, enquanto os grupos Morganti e Matarazzo tinham capitais investidos em diversos setores industriais. Apenas M. Junqueira era de origem agrária, ligado a atividades pecuárias (Ramos, 1983, p. 76; Andrade, 1994, p. 168).

Nesse cenário, a produção de açúcar paulista teve amplas condições de se intensificar, aumentando aproximadamente em $84 \%$ entre as safras de 1946/1947 e de 1951/1952, passando de 4,4 milhões de sacos para 8,1 milhões. O estado de São Paulo assumia, portanto, a primeira posição entre os produtores de açúcar, superando o estado de Pernambuco, desde os tempos coloniais o maior produtor açucareiro do Brasil. Além disso, São Paulo passou a ser praticamente autossuficiente em relação à sua demanda interna de açúcar e a comercializar o seu excedente para estados da região Sul e outros estados vizinhos, como Goiás, Mato Grosso e Paraná, prejudicando a comercialização do açúcar proveniente da indústria nordestina (Szmrecsányi, 1979, p. 219; Andrade, 1994, p. 40).

As medidas adotadas para o incentivo da produção açucareira, contudo, reavivaram um problema que sempre rondou a indústria canavieira - o da superprodução. As exportações foram uma boa saída momentânea, já que os preços no mercado externo, devido aos efeitos da IIGM, eram altos tanto na Europa como no Oriente. Entretanto, a recuperação da produção açucareira mundial no pós-guerra repercutiu rapidamente nos preços do açúcar, causando a sua baixa no mercado internacional.

Para possibilitar a venda do açúcar excedente no exterior a preços inferiores aos do mercado interno, o IAA criou o Fundo de Compensação dos Preços do Açúcar, com recursos advindos da taxa cobrada sobre o saco de açúcar fabricado, determinada desde 1941 pelo Estatuto da Lavoura Canavieira (Szmrecsányi, 1979, p. 220).

A função do Fundo era cobrir a diferença entre os preços dos mercados interno e externo de açúcar, mas acima de tudo financiar no- 
vamente a produção de álcool direto, não onerando os cofres públicos, além de possibilitar a liquidação de débitos contraídos pela agroindústria canavieira, principalmente nordestina, no Banco do Brasil e no IAA (Szmrecsányi, 1979, p. 220).

Em razão dos déficits na balança de pagamentos e do esgotamento das reservas cambiais no período da IIGM, causados, em parte, pela crescente importação da gasolina automotiva, o governo federal determinou, em meados de 1948, que o IAA adotasse medidas para o estímulo da produção de álcool anidro, estabelecendo para isso a equivalência entre os preços do açúcar e do álcool direto. Na mesma época, foi criado o Fundo do Álcool Anidro para atender as despesas de custeio das operações da economia alcooleira (Szmrecsányi, 1979, p. 221).

Essas medidas rapidamente alcançaram seus resultados, e já na safra de 1948/1949 a produção alcooleira atingiu a cifra de 167,3 milhões de litros (Szmrecsányi, 1979, p. 221).

A superprodução açucareira e a consequente baixa do preço do açúcar no mercado interno também propiciou a substituição da rapadura e do açúcar mascavo, produzido pelos engenhos banguês, pelo açúcar de usina, por parte do consumidor. Ciente da situação, o governo autorizou o IAA (Lei 964/1949) a executar o aproveitamento dos canaviais dos banguês, mediante a conversão de suas cotas de produção de açúcar em cotas de fornecimento de cana para as usinas localizadas nas suas zonas canavieiras ou a fusão dessas cotas de produção até o total de 30 mil sacos.

Assim, findava a era dos engenhos banguês no Brasil, os quais permaneceriam apenas na memória histórica da expansão canavieira e em alguns rincões do território nacional, com a produção artesanal de açúcar mascavo e rapadura.

3.3 Uma nova fase com uma velha solução:

o retorno às exportações

A superprodução açucareira brasileira fez com que a partir de meados da década de 1950, a política do governo federal passasse a fomentar novamente a exportação dos produtos tradicionais oriundos da cana, do açúcar e do álcool, mas também do melaço. 
Inicialmente, essa política de exportação se desenvolveu de maneira flutuante, por meio do subsídio de preços do açúcar que não era absorvido no mercado interno, sobretudo nas várias crises de superprodução. Depois, ao final de década de 1960, passou a ser uma das principais estratégias para a ampliação da aquisição de divisas, mantendo-se inclusive na atualidade.

A década de 1950 transcorreu, dessa forma, marcada pela expansão da agroindústria canavieira, inicialmente determinada pela crescente demanda interna provocada pelo surto de industrialização e urbanização promovido pela política desenvolvimentista de Juscelino Kubitschek (Szmrecsányi, 1979, p. 236/237).

Essa expansão foi incentivada pelo IAA, que logo no início da década liberou a produção de açúcar em todo o país para a safra de 1950/1951 e determinou uma cota especial para a produção do álcool direto, correspondente a 10\% da cota geral de produção de açúcar.

Em 1957, as cotas de produção de açúcar de usina foram elevadas, alcançando a cifra de 47,7 milhões de sacos, repartidas entre as usinas proporcionalmente à maior produção alcançada entre as safras de 1951/1952 e 1956/1957 (Tabela 7). A partir desse momento, a distribuição espacial da produção deixou de existir e a hegemonia da agroindústria canavieira do Centro-Sul, sobretudo de São Paulo, foi confirmada oficialmente (Szmrecsányi, 1979, p. 237-239, 248).

O contínuo crescimento da produção açucareira brasileira, atingindo na safra de 1958/1959, o volume de 53,7 milhões de sacos, o desequilíbrio entre a produção e o consumo nacionais de açúcar e o consequente aumento de seus excedentes fizeram com que o IAA direcionasse sua atenção mais uma vez para o mercado externo, voltando o Brasil, a partir de então, a participar ativamente do mercado açucareiro mundial, apesar dos preços baixos (Szmrecsányi, 1979, p. 250).

Assim, as exportações, que somavam, em 1957, aproximadamente 424 mil toneladas, chegaram, em 1958, à casa das 780 mil toneladas. $\mathrm{O}$ açúcar assumia novamente a posição de importante produto na pauta de exportações, sendo superado apenas pelo café e pelo cacau (Szmrecsányi, 1979, p. 250). 
Tabela 7. Reajuste das cotas de produção de açúcar de usina (Resolução IAA 1284/1957)

\begin{tabular}{|c|c|c|}
\hline ESTADOS PRODUTORES & LIMITE ANTERIOR & COTAS REAJUSTADAS \\
\hline Pernambuco & 9.393 .350 & 12.717 .932 \\
\hline São Paulo & 8.232 .914 & 15.084 .701 \\
\hline Rio de Janeiro & 4.925 .151 & 6.275 .476 \\
\hline Alagoas & 3.153 .708 & 4.147 .987 \\
\hline Minas Gerais & 1.898 .166 & 2.480 .606 \\
\hline Sergipe & 1.682 .950 & 2.026 .341 \\
\hline Bahia & 1.599 .441 & 1.854 .510 \\
\hline Paraíba & 728.556 & 920.271 \\
\hline Paraná & 458.880 & 852.822 \\
\hline Espírito Santo & 304.560 & 327.625 \\
\hline Santa Catarina & 210.715 & 254.137 \\
\hline Rio Grande do Norte & 192.601 & 309.070 \\
\hline Goiás & 171.780 & 187.828 \\
\hline Mato Grosso & 154.745 & 169.673 \\
\hline Pará, Maranhão, Piauí e Ceará & 119.689 & 140.593 \\
\hline TOTAL & 33.227 .206 & 47.749 .572 \\
\hline
\end{tabular}

Fonte: Tamás SZMRECSÁNYI, 1979, p. 248. Org.: dos Autores, 2019.

A solução baseada nas exportações, contudo, apresentava limitações. Por ser o açúcar nessa época um produto gravoso ${ }^{11}$, sua comercialização era subsidiada pelo IAA, cujos recursos, não sendo suficientes, eram complementados por fundos da Superintendência da Moeda e do Crédito (Sumoc) e da Carteira de Comércio Exterior (Cacex) do Banco do Brasil (Szmrecsányi, 1979, p. 250). Além disso, o único mercado ao qual o Brasil tinha acesso para as exportações de açúcar era o Mercado Livre Mundial (MLM), que tinha um caráter residual diante dos mer-

\footnotetext{
${ }^{11}$ Produto gravoso é a "mercadoria exportável que, dado o seu alto custo de produção, não pode competir, no mercado internacional, com os similares estrangeiros, ficando, assim, na dependência de medidas protecionistas por parte do governo" (FERREIRA, 2009, p. 1003).
} 
cados preferenciais (MPs), absorvendo apenas um terço do comércio internacional de açúcar (Szmrecsányi, 1979, p. 251).

Diferentemente do Brasil, outros grandes produtores de açúcar, como Cuba, República Dominicana e Formosa, participavam também do MP norte-americano, cujos preços eram bem mais vantajosos do que os do MLM (Szmrecsányi, 1979, p. 251).

Nesse cenário, várias medidas passaram a ser tomadas pelo governo, semelhantes àquelas adotadas nos anos de 1930 e 1940. No âmbito interno, baseando-se na demanda do mercado interno e nos compromissos internacionais de exportação, o IAA fixou a cota de produção açucareira total em aproximadamente 50,9 milhões de sacos para a safra de 1959/1960 (Szmrecsányi, 1979, p. 251). Limitou o período de moagem de cana, cujo início passou a ser em $1^{\circ}$ de junho para a região Centro-Sul e $1^{\mathrm{o}}$ de setembro para o Norte/Nordeste, e determinou a constituição de "estoques de retenção" a serem formados pelo açúcar retirado do mercado, das safras de 1959/1960 a 1962/1963, das usinas localizadas nos estados que mais produziam, ou seja, Pernambuco, Alagoas, Rio de Janeiro e São Paulo, mediante financiamento correspondente a 80\% do preço oficial (Szmrecsányi, 1979, p. 253).

No âmbito externo, o panorama foi modificado com o rompimento das relações políticas e econômicas entre Cuba e Estados Unidos em 1960. O açúcar cubano foi excluído do mercado preferencial norte-americano, abrindo novas possibilidades para a exportação do açúcar brasileiro. Nesse ano, o Brasil conseguiu pela primeira vez exportar 100 mil toneladas para o MP norte-americano (Szmrecsányi, 1979, p. 254).

O açúcar cubano passou então a abastecer os países socialistas, que reduziram por sua vez a produção de açúcar de beterraba, antes comercializado no MLM. Além disso, a quebra sucessiva de safras de cana em Cuba fez com que países importadores de açúcar cubano procurassem outros mercados abastecedores, dentre os quais o Brasil (Szmrecsányi, 1979, p. 255).

A política econômica brasileira, a partir de então, voltou-se para a formulação de medidas para o incentivo das exportações de açúcar e para a ampliação da capacidade produtiva do parque indus- 
trial e das lavouras de cana. No governo de Jânio Quadros (1961), foi baixado o Decreto 50.818/1961, onde foram estabelecidas normas para a centralização e coordenação das atividades de exportação de açúcar e demais derivados de cana-de-açúcar no IAA (Szmrecsányi, 1979, p. 256). Nesse mesmo ano, foi criado o Fundo de Recuperação da Agroindústria Canavieira (Brasil, 1961), com recursos oriundos das exportações de açúcar para o MP norte-americano, com o objetivo de conceder financiamentos a usineiros, cooperativas de fornecedores e bancos de plantadores de cana, sobretudo do Nordeste, com prazos de 15 anos, a juros de 6\% a.a. e carência de 1 a 2 anos (Szmrecsányi, 1979, p. 257).

No Governo João Goulart (1961-64) foi criado o Fundo de Consolidação e Fomento da Agroindústria Canavieira, constituído de recursos provenientes do MP norte-americano e da comercialização do açúcar no mercado interno e no MLM. A motivação fundamental era o fomento das exportações de açúcar, mesmo em períodos em que se tornassem gravosas. Em 1962, nessa mesma linha de incentivos, o IAA firmou um convênio com o Banco do Brasil para o investimento de projetos destinados ao melhor aproveitamento da terra nas zonas canavieiras (Szmrecsányi, 1979, p. 258/259).

De forma diversa à que ocorrera anteriormente, as exportações não eram mais consideradas como um instrumento de defesa dos preços internos do açúcar, mas sim como uma fonte geradora de divisas (Szmrecsányi, 1979, p. 258/259). Nessa nova fase, o planejamento da agroindústria canavieira deixou de ter um caráter setorial, de curto prazo, com ações visando resolver problemas pontuais, passando a fazer parte do planejamento socioeconômico nacional, em uma escala de médio e longo prazos.

Nesse sentido, em 1963, foi formulado o Programa Diretivo para a Política Açucareira e Alcooleira, depois denominado Plano de Expansão da Indústria Açucareira Nacional, com a previsão da instalação de 50 novas usinas e de uma produção de 100 milhões de sacos de açúcar até 1971 - sendo 80 milhões destinados ao mercado interno e 20 milhões para exportação e para a formação de estoques reguladores (Szmrecsányi, 1979, p. 263-265). 
No mesmo ano, o IAA sancionou a ampliação de produção de açúcar das usinas para os 100 milhões de sacos, ficando quase $40 \%$ do limite nacional da produção concentrado nos estados de São Paulo e Paraná (Szmrecsányi, 1979, p. 264).

O aumento das cotas produtivas para 100 milhões de sacos de açúcar, em 1963, promoveu, portanto, a expansão da cultura canavieira na região Centro-Sul, em particular no estado de São Paulo, a partir de 1964. Tal impulso coincidiu com a campanha de erradicação de cafezais antieconômicos promovida pelo Instituto Brasileiro do Café (IBC), os quais foram substituídos em grande parte por cana-de-açúcar, ambos financiados pelo Banco do Brasil, fazendo com que os canaviais paulistas tivessem uma expansão de 22\% (Szmrecsányi, 1979, p. 272-273).

Do mesmo modo, o aumento nas cotas produtivas ampliou consideravelmente as disponibilidades de melaço para a produção do álcool residual. Como mistura carburante, o álcool apresentava tendência decrescente, à medida que a capacidade de refino de petróleo aumentava no país (Andrade, 1994, p. 33).

Apesar dos bons preços no MP norte-americano, a queda acentuada no MLM tornou gravosas as exportações brasileiras de açúcar, o que, associado à superprodução, fez cair abruptamente os valores do açúcar, cujo saco na região Centro-Sul, que era tabelado em $\operatorname{Cr} \$ 12,18$, passou a ser comercializado a $\mathrm{Cr} \$ 5,00$ ou $\mathrm{Cr} \$$ 6,00 (Szmrecsányi, 1979, p. 271-272). Assim, uma nova grande crise se estabeleceria no setor sucroalcooleiro em meados da década de 1960, com proporções semelhantes àquela ocorrida em 1929.

Diante dessa situação, o governo editou normas na tentativa de restabelecer a disciplina do mercado, reformulando a legislação para o planejamento do setor canavieiro (Quadro 3).

A partir do último quartel da década de 1960, a consolidação dos EUA como principal mercado externo para o açúcar brasileiro e o aumento do preço médio do açúcar no exterior fizeram com que a agroindústria canavieira brasileira começasse a se recuperar. 
Quadro 3. Normas editadas pelo IAA para disciplinar o mercado sucroalcooleiro em meados dos anos de 1960.

\begin{tabular}{|c|c|}
\hline Normas & Pontos principais \\
\hline Lei $4.870 / 1965$ & $\begin{array}{l}\text { Aumentos ou reduções da produção de açúcar fixados baseados na demanda do } \\
\text { mercado interno e externo. } \\
\text { Para a fixação do contingente de exportação de açúcar prevê a utilização pelo IAA } \\
\text { de recursos públicos criados ou que venham a ser criados para o fomento da ex- } \\
\text { portação de produtos gravosos, a fim de assegurar a defesa do preço e o equilíbrio } \\
\text { estatístico entre a produção e o consumo. } \\
\text { Autorização de fixação nos Planos Anuais de Safra de cota de retenção de até } 20 \% \\
\text { da produção nacional de açúcar, para a constituição de um estoque regulador do } \\
\text { abastecimento dos centros consumidores, estabilização dos preços no mercado } \\
\text { interno e cumprimento de acordos internacionais. } \\
\text { Â região Norte-Nordeste é atribuído, prioritariamente, o contingente de açúcar } \\
\text { destinado aos mercados preferenciais. } \\
\text { O preço do açúcar deixa de ser vinculado ao preço do álcool e passa a ser fixado } \\
\text { em função da produção geral agrícola e de uma parcela correspondente à porcen- } \\
\text { tagem de participação do fornecedor no rendimento anual da usina situado acima } \\
\text { do rendimento médio do estado, considerando o teor de sacarose e a pureza da } \\
\text { cana fornecida. } \\
\text { Instituição do Fundo Especial de Exportação. }\end{array}$ \\
\hline $\begin{array}{l}\text { Resolução IAA } \\
1.974 / 1966\end{array}$ & $\begin{array}{l}\text { Dispõe sobre a comercialização interna da safra de } 1966 / 1967 \\
\text { Divisão do território nacional em duas regiões açucareiras: a região Norte/NE } \\
\text { (estados e territórios da Amazônia “clássica" e o os do litoral da Bahia, inclusive) } \\
\text { e a região Centro-Sul (todos os demais), sendo que a comercialização do açúcar } \\
\text { entre as duas regiões ficava dependente de prévia autorização do IAA. }\end{array}$ \\
\hline DL 308/1967 & $\begin{array}{l}\text { Fixação de contribuições fixas para cada saco de açúcar e cada litro de álcool pro- } \\
\text { duzidos, sendo 60\% destinadas à constituição do Fundo Especial de Exportação. } \\
\text { Obrigatoriedade da aprovação dos Planos Anuais de safra até o dia } 30 \text { de abril } \\
\text { de cada ano. } \\
\text { Elevação do limite mínimo das usinas para } 200 \text { mil sacos. }\end{array}$ \\
\hline
\end{tabular}

Fontes: BRASIL, 1965; SZMRECSÁNYI, 1979, p. 276. Org.: dos autores, 2015.

Pela primeira vez, desde 1963, a produção mundial de açúcar se apresentava menor do que o consumo. Um novo acordo mundial foi assinado, em que o Brasil obteve uma cota de exportação de 500 mil toneladas anuais, ocupando o $6^{\circ}$ lugar entre 40 países exportadores signatários do acordo. Assim, os valores de exportação de produtos da agroindústria canavieira brasileira chegam a um total de US $\$ 112,8$ milhões em 1968, originados da comercialização de 1.078.00o TM de açúcar, 70.726 TM de mel rico, 141.177 TM de melaço e 13,8 milhões de litros de álcool (Szmrecsányi, 1979, p. 275).

Nessa época, também se observou o crescimento dos grupos tradicionalmente canavieiros, bem como a inserção de grupos de outros 
setores da economia, que atraídos pelo potencial retorno financeiro auferido pela evolução das atividades sucroalcooleiras, e também para se resguardar de possíveis crises econômicas, passaram a aplicar seus capitais nesse setor. São exemplos, em São Paulo, Ometto e Biaggi, da indústria siderúrgica; em Pernambuco, os Brito, vinculados à indústria de doces enlatados Peixe e que depois adquiriram usinas em Pernambuco e Alagoas; os Tavares de Melo, que iniciaram suas atividades com uma usina em Pernambuco e depois investiram na produção de alimentos (Maguary-Kibon) e em destilarias de álcool na Paraíba e em Mato Grosso do Sul; os Lyra, que controlavam várias usinas e destilarias em Alagoas; e os Wanderley, com a usina Coruripe e a destilaria de Camaçari (Andrade, 1994, p. 174-175).

Paulatinamente, antigos usineiros, empresários patriarcais, davam lugar às sociedades anônimas, inicialmente constituídas principalmente por parentes e familiares, que posteriormente se transformaram em grandes grupos econômicos, mas sem perder suas características familiares originárias (Andrade, 1994, p. 174-177).

Com o Golpe de 1964, o governo concluiu a busca por soluções nacionalistas para o desenvolvimento econômico. Apesar de continuar a incentivar as exportações, passou a praticar uma política de internacionalização da economia, abrindo-se para o capital estrangeiro (Andrade, 1994, p. 41).

Mas a consolidação da política de exportação do açúcar, de fato, requeria mais que ações de âmbito político-econômico. Necessitava, além do mercado internacional, de condições endógenas adequadas, as quais só podiam ser estabelecidas por meio de um planejamento a médio e longo prazos (Szmrecsányi, 1979, p. 290) abrangendo o desenvolvimento do conhecimento e de técnicas, tanto no setor agrícola como industrial, que se iniciaram de forma mais consistente a partir da década de 1960, e se consolidaram a partir dos anos de 1970.

\subsection{A tecnificação da agricultura e a conformação de} uma nova geografia canavieira

A primeira fase de modernização da indústria de açúcar e álcool, iniciada com a implantação dos engenhos centrais no final do século 
XIX, foi concluída em meados da década de 1950. Apesar de ter se dado com velocidades e intensidades variáveis nas duas regiões açucareiras brasileiras, em todas as grandes áreas canavieiras o sistema de produção industrial usineiro era predominante.

Entre 1930 e 1970, no setor industrial, diferentemente do ocorrido anteriormente, as mudanças tecnológicas foram pequenas, resumindo-se a aperfeiçoamentos de detalhes. Basicamente, as máquinas utilizadas apoiavam-se nos mesmos princípios adotados nas primeiras usinas implantadas, no final do século XIX e início do século XX, e o processo de produção de açúcar e de álcool se dava também de forma bastante semelhante. A grande mudança ocorreu na parte agrícola.

A tecnificação do campo, que na Europa já ocorria parcialmente desde o final do século XIX, com o uso de alguma adubação, generalizou-se a partir de meados do século XX, amplamente apoiada no desenvolvimento de motores a explosão ou elétricos, de tratores cada vez mais potentes, de máquinas agrícolas complexas e eficientes, do avanço da química agrícola, de produtos fitossanitários e da biotecnologia (Mazoyer e Roudart, 2010, p. 430).

A mecanização parcial da operação da colheita da cana se iniciou no Brasil na primeira metade da década de 1950, quando surgiram as primeiras carregadoras de cana, que substituíram o carregamento manual (Ripoli e Ripoli, 2009, p. 20). Na mesma época, a instalação nas usinas de sistemas de limpeza por via úmida possibilitou o uso do fogo como método despalhador, (Ripoli e Ripoli, 2009, p. 21/26), o que facilitou a colheita manual e aumentou a produtividade do trabalhador rural.

A melhoria técnica na agricultura se amalgamou às transformações industriais ocorridas anteriormente, engendrando efeitos importantes na expansão do setor sucroalcooleiro brasileiro e, por conseguinte, na geografia canavieira.

A introdução do uso de máquinas modernas, de agroquímicos e de espécies de cana-de-açúcar melhor adaptadas às variadas exigências de solo e clima, vinculada à conjuntura política e econômica, possibilitou o uso de solos antes inadequados ao cultivo da cana-de-açúcar, apesar de localizados em áreas com climas e relevos favoráveis. 
Na época dos engenhos banguês, a determinação das áreas a serem cultivadas pela cana-de-açúcar tinha sido realizada tendo em vista as condições topográficas, a fertilidade dos solos, a distância dos corpos d'água, a acessibilidade. A rotação de culturas predominava, ficando a terra em pousio depois de certo número de cortes da cana, para ser coberta pela capoeira que crescia naturalmente. Após a fertilidade ter retornado ao solo, o terreno era reutilizado novamente, plantando-se um novo canavial. A adubação era praticamente inexistente, e pouca preocupação se tinha com as variedades de cana utilizadas.

Uma das primeiras manifestações da mudança no sistema agrícola se deu com a introdução dos fertilizantes. Por meio da adubação, obteve-se um rendimento agrícola maior e gradualmente a prática do pousio e da rotação de terras não era mais necessária, sendo abandonada. A paisagem rural das áreas canavieiras, consequentemente, se modificou. Já não se observava com tanta frequência e com a mesma extensão os terrenos com capoeiras (Melo, 1975, p. 104). Criações e pequenas lavouras de subsistência foram sendo substituídas por canaviais que gradualmente formaram um continuum no espaço.

Até meados da década de 1930, o Nordeste detinha o predomínio na produção açucareira, seguido pelo Rio de Janeiro. Das 13 maiores usinas no território brasileiro, dez localizavam-se no Nordeste, uma no Rio de Janeiro e outra em São Paulo.

Nos estados do Nordeste Oriental, tradicionalmente a cana ocupava apenas as várzeas quaternárias encravadas nos tabuleiros arenosos, com altitudes que variavam dos $100 \mathrm{~m}$ aos $150 \mathrm{~m}$. Antes da cana, os tabuleiros eram ocupados pela pecuária extensiva e por sítios de pequenos proprietários e arrendatários que cultivavam mandioca, inhame, frutas etc. Em alguns vales, como o do Ceará-Mirim (RN), o do Paraíba do Norte (PB) e o do Mundaú (AL), os engenhos se enfileiravam no sopé das encostas como que formando um rosário, e os canaviais ocupavam as várzeas úmidas, enquanto os tabuleiros eram deixados às capoeiras ou a outras atividades (Andrade, 1994, p. 110).

Mas a cana-de-açúcar não precisava mais ficar circunscrita às áreas naturalmente férteis litorâneas ou do interior paulista. Com o uso dos fertilizantes era possível a sua expansão em solos antes con- 
siderados impróprios, como foi o caso dos tabuleiros litorâneos nordestinos.

Os tabuleiros litorâneos são formações terciárias que se estendem paralelamente à costa litorânea, desde o Amapá até o Rio de Janeiro, tornando-se menos extensos em Pernambuco, onde o cristalino, em alguns trechos, alcança o litoral. Seus solos arenosos originariamente possuem limitações químicas, devido ao baixo teor de matéria orgânica, e físicas, por possuírem horizontes coesos subsuperficialmente, o que dificulta a infiltração da água e impede o aprofundamento do sistema radicular das plantas.

Dessa forma, em meados da década de 1950, os tabuleiros costeiros alagoanos, cobertos por Argissolos Vermelho-Amarelos distróficos e com baixa fertilidade natural, puderam ser amplamente utilizados por meio do uso de adubos e sistemas de irrigação.

A irrigação, além de regular o suprimento de água nos meses de seca, possui importância para reduzir a coesão do solo, que se torna mais friável com a presença da água, favorecendo a penetração do adubo. Associadamente, técnicas voltadas à drenagem das amplas planícies fluviais dos rios Manguaba, do Camarajibe, do Santo Antônio, do Mundaú, do Paraíba do Meio, do São Miguel, do Jiquiá e do Coruripe possibilitaram o seu pleno uso pela atividade canavieira. As matas alagoanas foram então derrubadas para dar lugar aos canaviais (Andrade, 2005, p. 41).

Assim, os tabuleiros do Sul alagoano tornaram-se, nas palavras de Heredia (1988), a "meca" de fornecedores e usineiros alagoanos, e também dos pernambucanos, que para lá foram (Heredia, 1988 p. 68).

De fato,

As canas nas várzeas apresentavam uma produtividade agrícola muito elevada, superior a $100 \mathrm{t} / \mathrm{ha}$, mas, sendo muito hidratadas, tinham uma baixa produtividade industrial. As canas de tabuleiro, com produtividade em torno de 60 ou $70 \mathrm{t} / \mathrm{ha}$, tinham essa produtividade agrícola compensada com a elevada produtividade industrial. Esse fato fez com que em Alagoas os canaviais passassem a se expandir por áreas não canavieiras, enquanto em Pernambuco, que só dispunha de tabuleiros na porção da Mata Seca, ao Norte de Recife, essa expansão não foi tão 
grande, o que fez a produção de cana alagoana superar a pernambucana (Andrade, 1994, p. 111).

Mesmo assim, Pernambuco se manteve como o segundo maior estado produtor de açúcar de usina e de área colhida, sendo ultrapassado apenas por São Paulo (Tabela 8).

Tabela 8. Produção de açúcar de usina e área colhida das unidades da federação, 1970.

\begin{tabular}{|c|c|c|}
\hline Unidades da Federação & 1970 & Safra $1971 / 72$ \\
\hline & Área colhida (100o ha) & Toneladas \\
\hline Rondônia, Acre, Amazonas, Roraima e Amapá & 3 & \\
\hline Pará & 13 & \\
\hline Maranhão & 21 & 3684 \\
\hline Piauí & 16 & 2412 \\
\hline Ceará & 58 & 14208 \\
\hline Rio Grande do Norte & 13 & 32526 \\
\hline Paraíba & 43 & 89952 \\
\hline Pernambuco & 239 & 1039062 \\
\hline Alagoas & 119 & 563718 \\
\hline Sergipe & 26 & 46632 \\
\hline Bahia & 90 & 56922 \\
\hline Sub-total Norte/Nordeste & 641 & 1849116 \\
\hline Minas Gerais & 222 & $\mathrm{O}$ \\
\hline Espírito Santo & 25 & 237138 \\
\hline Rio de Janeiro & 145 & 22236 \\
\hline São Paulo & 524 & 443340 \\
\hline Paraná & 37 & 2596746 \\
\hline Santa Catarina & 35 & 166692 \\
\hline Rio Grande do Sul & 54 & 32346 \\
\hline Mato Grosso & 11 & 16872 \\
\hline Goiás & 31 & 4200 \\
\hline Sub-total Centro-Sul & 1084 & 3519570 \\
\hline
\end{tabular}

Fonte: SZMRECSÁNYI, 1979, p. 66/458/459. Org.: dos Autores, 2019. 
Durante séculos, as curtas distâncias entre os portos nordestinos e europeus foram grande vantagem para a região açucareira nordestina. Porém a localização do maior centro consumidor do país em São Paulo foi muito mais vantajosa no século XX. Entre os anos de 1940 e 1950, grande número de usinas foi implantado no Oeste de São Paulo e no Norte do Paraná (Andrade, 1994, p. 60).

Nas áreas ocidentais mineiras, o clima com duas estações definidas, uma úmida e outra seca, foi muito propício ao cultivo da cana, sobretudo nas áreas mais baixas próximas aos grandes rios, como Grande e Paranaíba, onde se encontram os solos férteis, originados do basalto.

A Bahia, importante produtor no período da Primeira República, que em 1935 possuía 1.381 engenhos banguês e 16 usinas concentradas no Recôncavo, teve seu papel bastante reduzido, sendo que em 1972 possuía apenas seis unidades produtivas.

O desenvolvimento industrial do Recôncavo, com a implantação da cidade Industrial de Aratu, em 1968, a descoberta e a exploração do petróleo e a instalação do polo de Camaçari, em 1978, e as restrições edáficas, fizeram com que o antes importante setor canavieiro baiano perdesse definitivamente expressão (Andrade, 1994, p. 97/100).

A mecanização trouxe grandes repercussões no setor agrícola da agroindústria canavieira. Embora anteriormente o mercado agrícola já fosse suprido por máquinas provenientes dos EUA, da Europa e de alguns países socialistas, as várias procedências do maquinário dificultavam a assistência técnica, a reposição de peças e até o próprio conhecimento do uso do maquinário (Amato Neto, 1985, p. 59/64). Algumas ferramentas manuais e instrumentos agrícolas já eram utilizados e produzidos no Brasil, mas só o uso efetivo dos tratores, associados à fertilização química, criou condições propícias para a penetração definitiva da modernização no setor agrícola. Assim, sob a égide do governo desenvolvimentista de $\mathrm{JK}$,
(...) a mecanização agrícola se iniciou no país com a instalação da indús- tria de tratores no ano de 1959, quando foi instituído o Plano Nacional da Indústria de Tratores de Rodas, sendo que as primeiras unidades co- meçaram a ser produzidas em 1960 (Amato Neto, 1985, p. 59). 
Além das empresas, principalmente de capital estrangeiro, instaladas nos anos de 1960 (Quadro 4), outras empresas nacionais fabricavam maquinaria completa e peças para usina de cana-de-açúcar e destilarias de álcool, como a Metalúrgica Dedini (Müller, 1989, p. 29), peças de reposição e implementos leves para a agricultura canavieira, tais como enxadas, foices, arados e outros equipamentos de maior complexidade.

Quadro 4. Primeiras empresas fabricantes de tratores implantadas no Brasil (1959).

\begin{tabular}{|c|c|c|}
\hline Fabricantes & Marca do trator & Origem do capital \\
\hline Marsey-Fergusson & Marsey-Fergusson & Canadá \\
\hline Frendt do Brasil & Frendt & Inglaterra \\
\hline Valmet do Brasil & Valmet & Finlândia \\
\hline Ford do Brasil & Ford & EUA \\
\hline Demissa & Deutz & Alemanha \\
\hline Companhia Brasileira de Tratores (CBT) & Oliver & Brasil/EUA \\
\hline
\end{tabular}

Fonte: AMATO NETO, 1985, p. 65.

Dessa forma, a paisagem das regiões açucareiras foi mudando, ocupada intensivamente pela lavoura canavieira. $\mathrm{O}$ aumento da produtividade passou a ser dado não mais apenas pela aquisição de novas terras, mas sim pela intensificação do plantio da cana-de-açúcar.

\subsection{Impactos socioambientais da tecnificação da cultura canavieira}

O avanço do modo de produção do açúcar usineiro e de álcool causou a expansão da cana-de-açúcar, o que originou dois impactos socioambientais de grande magnitude, que se ampliaram durante os anos de 1960, consolidando-se na década de 1970: a concentração fundiária e a expansão agrícola.

A partir do final dos anos de 1800, a implantação de usinas foi 
sendo consolidada com a aquisição de antigos engenhos situados nas suas zonas de influência que pudessem se tornar fornecedores de canade-açúcar. Deve-se destacar que muitas dessas aquisições foram sendo determinadas mais pela perspectiva de ampliação da capacidade produtiva da usina do que pela quantidade de cana moída de fato, gerando o que Melo (1975, p. 55) denominou de "reservas estratégicas de espaço produtivo".

Dessa forma, muitas usinas preferiam, inclusive, utilizar seus recursos na aquisição de mais propriedades do que na introdução de melhoramentos técnicos e agrícolas, o que provocou o aumento do preço da terra (Melo, 1975, p. 56). Na região nordestina, esse processo afetou a estrutura agrária, pois apesar de ser caracterizada por propriedades cuja extensão variava em torno de 400 a 1.000 hectares, possuía milhares de engenhos (Melo, 1975, p. 58).

O uso de modernas técnicas de plantio e manejo do solo permitiu a expansão dos canaviais em áreas antes consideradas inaptas e praticamente extinguiu o antigo sistema de pousio e as capoeiras. Antigas áreas cobertas por matas, antes conservadas para o abastecimento de madeira para as fornalhas, também não eram mais necessárias, tendo em vista a alimentação das caldeiras das usinas ser feita com óleo diesel, e, por isso foram também integradas à ocupação canavieira.

A expansão do cultivo canavieiro nos tabuleiros nordestinos, sobretudo alagoano, destruiu sistematicamente as matas que antes os cobriam. Heredia, (1988) referindo-se aos tabuleiros alagoanos, descreve:

Quem percorresse essa área através da estrada nacional, que a atravessa em direção Norte-Sul, teria em 1970 como visão permanente as matas em ambos os lados do caminho. Hoje, o mesmo viajante, atravessando o mesmo local, defrontar-se-á com uma paisagem totalmente diversa. Se as matas impediam então a visão do horizonte, hoje sua ausência total permite que apareça claramente os tabuleiros, configurados como imensas extensões - "planícies" - que se perdem na distância. (...) A extensão dos tabuleiros e sua ocupação pela cana é expressa na Área, como um "mar de cana". (Heredia, 1988, p. 75) 
Tal expansão fez com que pequenos produtores, que ocupavam esses mesmos tabuleiros, se deslocassem em direção aos vales dos rios (Heredia, 1988, p. 75).

Esse processo de expropriação de lavradores se deu em todas as regiões açucareiras brasileiras, impulsionado em parte pela promulgação do Estatuto do Trabalhador Rural em 1963. Os trabalhadores rurais haviam se mantido à margem dos direitos estabelecidos na Consolidação das Leis Trabalhistas (CLT) até o início dos anos de 1960 (Andrade, 1994, p. 200). O Estatuto do Trabalhador Rural procurou equiparar as relações de trabalho do campo às da cidade, ignorando as especificidades das relações trabalhistas de cada região do território nacional, bem como a sua organização agrária. Embora oficialmente a intenção fosse oferecer proteção ao trabalhador rural, os encargos trabalhistas determinados pelo estatuto, tais como repouso remunerado, seguro de acidente, $13^{\circ}$ salário, indenização em caso de demissão, fizeram com que os usineiros e fornecedores de cana procurassem reduzir ao mínimo o número de trabalhadores passíveis de possuírem ou comprovarem algum vínculo empregatício (Melo, 1975, p. 240-245).

Tal processo, associado à possibilidade da intensificação do uso da terra, levou à expropriação dos trabalhadores-moradores, entre os anos de 1960 e 1970, transformando-os em trabalhadores avulsos, sem vínculo com uma usina específica, para não configurar vínculo empregatício.

Esse processo de proletarização excluiu o trabalhador morador no Nordeste, eliminou o colono em São Paulo e nos estados vizinhos. No Nordeste, os antigos trabalhadores recebiam um sítio para cultivar suas lavouras de subsistência, onde plantavam mandioca, milho, feijão, batata doce, inhame, banana e algumas hortaliças, possuindo muitas vezes alguns animais de carga e domésticos, como aves, porcos e cabras. Como pagamento pelo uso da terra, davam parte da colheita e/ou alguns dias de trabalho semanal, o que variava de região para região ou até de engenho para engenho (Andrade, 1994, p. 202; Eisenberg, 1977, p. 203; Melo, 1975, p. 106).

Em São Paulo, o sistema de colonato foi utilizado desde a segunda 
metade do século XIX, introduzido na área cafeeira para a substituição da mão de obra escrava. Geralmente originários da Itália, os colonos se estabeleciam nas fazendas de café, recebendo uma casa para morar, sementes, insumos e um terreno, onde plantavam pés de café e culturas de subsistência, intercaladas entre os pés de café. Recebiam em moeda um valor estipulado pelo proprietário da terra correspondente ao cafezal sob sua guarda (Andrade, 1994, p. 190, 204-205).

Nas fazendas canavieiras, o sistema manteve suas características. O proprietário fornecia o financiamento durante a entressafra, as sementes, as máquinas agrícolas e os insumos necessários, pagando um valor correspondente à quantidade de toneladas de cana fornecida pelo colono à indústria (Andrade, 1994, p. 190, 204-205).

Apesar de preponderantemente as lavouras desses sítios terem o caráter de subsistência, uma parcela de sua produção era comercializada localmente, contribuindo, em parte, para o abastecimento alimentar das áreas de entorno.

No Centro-Sul, os canaviais expandiram-se em antigas áreas ocupadas por cafezais, que algumas vezes já haviam sido substituídos por culturas de algodão, cereais ou por pecuária extensiva. O fim do sistema de colonato fez com que a demanda por mão de obra para a cultura da cana fosse resolvida com os fluxos migratórios, sobretudo de nordestinos e de mineiros, que iam para São Paulo e, em seguida, para os estados do Paraná, Mato Grosso do Sul, Goiás, Mato Grosso e Tocantins (Andrade, 1994, p. 205).

A moradia desses trabalhadores em aglomerados urbanos provocou uma série de impactos indiretos, mas de grande magnitude, nas cidades que os acolhiam, que sem equipamentos e serviços suficientes para o atendimento dessa população, tinha a sua qualidade urbana deteriorada.

Assim, apesar de continuarem a trabalhar na grande lavoura canavieira, deixavam de possuir qualquer relação permanente com a terra que cultivavam. As relações de trabalho passavam a ser baseadas na produção ou na unidade de área, tendo à frente o empreiteiro (Melo, 1975, p. 209). Pequenos produtores migrantes engrossavam essa leva de trabalhadores sazonais, fazendo uma migração pendular, não se fi- 
xando na área de trabalho, retornando à sua terra natal na época das chuvas para fazerem o plantio de suas lavouras (Andrade, 1994, p. 212).

Melo (1975), em pesquisa sobre a agroindústria açucareira nos estados de Alagoas e Pernambuco, teceu considerações a respeito dos aspectos socioculturais desses trabalhadores, que consideramos ser análogos às situações vivenciadas em todas as áreas açucareiras brasileiras da época.

Sem dúvida o êxodo rural dessa parcela de trabalhadores causou uma melhoria no quesito da alfabetização, considerando-se que o índice de analfabetismo, em 1964, era em Pernambuco de 81\%, e que, em 1970, o Censo do IBGE apontava que em microrregiões canavieiras o índice era de 58\%. No entanto, foi revelada uma situação ainda bastante insatisfatória (Melo, 1975, p. 213).

No âmbito sociocultural, cabe registrar o consumo de bebida alcóolica de forma generalizada e de aguardente, o que tornava mais precárias as condições de saúde desses trabalhadores, como também agente da violência no comportamento desses indivíduos (Melo, 1975, p. 215).

A proletarização dessa categoria de trabalhadores causou, sem dúvida alguma, um impacto social muito grande, porque além das péssimas condições de moradia na área urbana, sem a lavoura de subsistência, eles se viram obrigados a comprar os produtos que necessitavam em casas comerciais, muitas vezes da própria usina ou do proprietário do latifúndio canavieiro, onde os preços eram abusivos e a qualidade baixa.

Tal fato foi constatado em trabalho realizado pelo Instituto Joaquim Nabuco de Pesquisas Sociais sobre o nível de vida do trabalhador rural na Zona da Mata em 1961, e complementado por outro estudo, em 1964, concluindo-se que

a) havia ausência quase que generalizada de condições satisfatórias no tocante ao bem-estar econômico, social e cultural (Maciel, 1964);

b) havia um estado de subnutrição devido ao reduzido consumo de alimentos essenciais e ricos em calorias; na maioria dos casos, 
as refeições se limitavam a um pirão d'agua com um pedaço de carne ou peixe. Muitos trabalhadores seguiam para o trabalho, pela manhã, sem nenhum alimento (Maciel, 1964);

c) o estado de carência, aliado às más condições higiênicas pessoais e do ambiente, provocavam consequentemente doenças do aparelho digestivo (Maciel, 1964);

d) quanto ao grau de instrução, era de $81 \%$ a taxa de analfabetos; de $5 \%$ a dos que sabiam ler, escrever e contar; e de $11 \%$ a dos que possuíam curso primário incompleto (Melo, 1975, p. 210 baseado em Gonçalves, 1966);

e) as habitações eram precárias, sendo que 40\% das pessoas "dormiam no chão ou em cima de sacos, lonas, esteiras, etc." (Melo, 1975, p. 210 baseado em Gonçalves, 1966).

Essas condições de vida faziam com que houvesse a prevalência de parasitoses intestinais, que a estatura fosse quase sempre inferior à mediana do país, e que grande parte dos jovens e crianças apresentasse raquitismo (Melo, 1975, p. 211).

Outro aspecto a ser destacado é que a eliminação dos trabalhadores-moradores e a compra das mais bem localizadas e melhores terras por grandes proprietários canavieiros causou a redução da quantidade de produtos alimentares antes produzidos nas pequenas lavouras dos sítios (Andrade, 1994, p. 205). Em Pernambuco, a produção per capita, entre 1961 e 1971, de produtos alimentícios decresceu grandemente, passando de $209 \mathrm{~kg}$ de mandioca para $167 \mathrm{~kg}$; de 4,1 kg de milho para 2,1 kg; e, de 1,3 kg de feijão para o,8 kg (Melo, 1975, p. 111).

Outro impacto que pode ser identificado como resultante da inserção das tecnologias mais modernas no setor agrícola, tais como a mecanização, a adubação química e o uso de agrotóxicos, foi a redução do número de trabalhadores no campo. Com o uso dos novos implementos agrícolas a partir dos anos de 1950, gradativamente foram sendo reduzidas as atividades manuais para o preparo do solo e o número de limpas anuais da cultura canavieira.

Ressalta-se que a mecanização nesse período se deu de forma parcial, pois apesar de atingir várias fases do processo de produção da 
cana, a colheita ainda era realizada manualmente, em grande parte pelos trabalhadores temporários, requisitados amplamente nessa fase e posteriormente liberados na entressafra, o que se adequava extremamente à dinâmica capitalista do setor agrícola da agroindústria canavieira (Müller, 1989, p. 76).

A introdução do uso do fogo como método despalhador, nos anos de 1950, facilitou o corte da cana pelos trabalhadores, mas afetou os solos, a atmosfera e a saúde da população do entorno dos canaviais e dos trabalhadores. Embora não haja dados, o uso do fogo provocou a inserção da etapa de limpeza das canas quando recebidas nas usinas, o que forçosamente resultou em grande aumento do consumo de água pela indústria.

Em síntese, a partir da década de 1930, grandes modificações ocorreram na agroindústria canavieira. Com o Governo Getúlio Vargas, inicia-se um novo período na política econômica canavieira, caracterizada pelo seu aspecto intervencionista, cujas medidas foram direcionadas principalmente à política de preços, tendo em vista a quase permanente superprodução de açúcar. Utilizando-se de diferentes instrumentos, tais como financiamento da produção açucareira e alcooleira, exportações gravosas, regime de contingenciamento da produção do açúcar, acabou por desencadear efeitos diferentes nas duas grandes regiões canavieiras, Norte/Nordeste e Centro-Sul.

O Norte/Nordeste foi se caracterizando por uma economia canavieira cada vez mais débil, perdendo seu mercado interno e externo devido a problemas conjunturais, mas também estruturais, da sua indústria, sendo que em meados da década de 1960 o único fator que justificava a manutenção da atividade era o baixo custo da mão de obra e a política assistencialista governamental.

São Paulo, ao contrário, expandiu seus canaviais em direção Oeste e Sul, alcançando os solos férteis do Paraná. Possuidor de capital industrial e comercial disponível para a aplicação em setores econômicos rendosos, de um parque industrial consistente e de um amplo mercado interno, ultrapassou a produção açucareira de Pernambuco em meados da década de 1950, assumindo a posição de novo polo açucareiro. 
As fases de preços altos continuaram sendo episódicas, refletindo os acontecimentos exógenos, conjunturais, de âmbito internacional. Contudo, a partir de meados da década de 1960, essa situação começou a se modificar. A implantação gradual de novas técnicas de cultivo e de modernos implementos agrícolas, associada à crise internacional do petróleo do início dos anos de 1970, induziu a instauração de uma nova política econômica do setor, direcionada ao revigoramento da produção alcooleira e à ampliação da produção e da exportação dos produtos canavieiros, como será tratado no próximo capítulo. 


\section{A AGROINDÚSTRIA SUCROALCOOLEIRA E O PROÁLCOOL}

\subsection{Depois da bonança, a tempestade}

Os anos de 1970 marcaram o início de uma nova fase na agroindústria canavieira. As relações entre indústria e agricultura passaram por transformações notáveis, da lavoura, sobretudo dos produtos agrícolas exportáveis, à força de trabalho; da gestão das unidades de produção ao entrelaçamento dos setores agrícola e industrial.

Entre 1966 e 1973, o consumo mundial de açúcar centrifugado aumentou de 61,1 milhões para 78,1 milhões de toneladas, ao passo que a produção mundial passou de 64,1 milhões de toneladas para 77,3, acarretando a redução dos estoques mundiais de açúcar (Melo, 1975, p. 273).

O consumo de açúcar no Brasil, como no restante do mundo, cresceu significativamente, impulsionado pelo padrão de consumo e pelo crescimento vegetativo da população. Na década de 1930, o consumo médio de açúcar no país era de $15 \mathrm{~kg}$ por habitante/ano; nos anos 1940, 22 kg/hab/ano; em 1970, de 40 kg/hab/ano; e, em 1990, o índice se estabilizou em $50 \mathrm{Kg} / \mathrm{hab} / \mathrm{ano}$.

Diante desse cenário, no início da década de 1970, a cana-de-açúcar voltou a ser uma das principais lavouras cultivadas no Brasil (Tabela 9), reflexo da política econômica direcionada à agroindústria canavieira, novamente voltada às exportações e apoiada nelas. 
Tabela 9. Principais lavouras cultivadas no Brasil em 1973.

\begin{tabular}{|c|c|}
\hline Produtos & Área colhida (ha) \\
\hline Milho em grão & 9.908 \\
\hline Arroz em casca & 4.795 \\
\hline Feijão em grão & 3.815 \\
\hline Soja em grão & 3.615 \\
\hline Algodão arbóreo & 2.347 \\
\hline Cana-de-açúcar & 2.210 \\
\hline
\end{tabular}

Fonte: SZMRECSÁNYI, 1979, p. 46. Org.: dos autores, 2015.

Em 1971, as exportações brasileiras de açúcar atingiram 1,2 milhão de toneladas, aproximadamente $6 \%$ de todo o açúcar circulante no mercado internacional. O Brasil passou a ser, a partir da safra de 1971/1972, o primeiro produtor mundial de açúcar e o segundo país maior exportador mundial, antecedido apenas por Cuba (Szmrecsányi, 1979, p. 302).

Essa expansão foi motivada pelo aumento do consumo mundial de açúcar, mas também por outros aspectos circunstanciais que não podem ser esquecidos. A brusca queda na produção cubana, que coincidiu com a redução das colheitas de beterraba dos países da Europa Oriental, levou os países socialistas, sobretudo a URSS e a China, a grandes compras de açúcar no Mercado Livre Mundial. O aumento da demanda e dos preços no mercado internacional, a redução de estoques de açúcar, a consequente elevação dos preços internacionais e a existência da capacidade ociosa na agroindústria açucareira brasileira nesse momento beneficiaram sobremaneira o setor açucareiro brasileiro, elevando o total de açúcar exportado para 2.977 mil toneladas em 1973 (Szmrecsányi, 1979, p. 301-303).

A produção de açúcar de usina que anteriormente era de 8,25 milhões de sacos, na safra de 1973/1974 passou para 111,38 milhões. Tal incremento foi possível, sobretudo, pela expansão da produção no Centro-Sul, que aumentara praticamente 30 vezes nesse período, passando de 2,65 milhões de sacos para 78,46 milhões, enquanto no Nordeste, a produção aumentou seis vezes, passando de 5,6 milhões para 32,9 milhões (Melo, 1975, p. 115). 
Até o final de 1974, os preços do açúcar continuaram a aumentar até US $\$ 1.388,56$ por tonelada, fazendo com que voltasse a ser o principal produto na pauta de exportações brasileiras, com a arrecadação de mais de US $\$ 1,3$ bilhão em divisas (Szmrecsányi, 1979, p. 307).

Nessa conjuntura, a política econômica nacional para o setor tratou de se direcionar para a expansão da capacidade produtiva e das exportações, editando várias medidas orientadas para o estímulo e a ampliação da produção (Melo, 1975, p. 282).

O sistema de preços do açúcar e de matéria-prima em vigor até o início dos anos de 1970 era baseado nos preços médios regionais. Extinto em 1971, pela Deliberação do Conselho Monetário Nacional $\mathrm{n}^{0}$ 2.059/197, foi substituído pelo sistema de preço único para todo o país. Para equilibrar a diferença do preço entre o açúcar nordestino e do Centro-Sul, o governo federal subsidiou temporariamente o produtor de cana e/ou de açúcar nordestino até a safra de 1977/1978 (Melo, 1975, p. 290/291).

Com essas medidas de subvenção, o setor canavieiro nordestino voltou a desempenhar papel importante na economia brasileira, retomando o seu papel de importante fornecedor de um produto relevante na pauta de exportações brasileiras, sendo responsável, em 1974, por 41\% do total da produção nacional (Melo, 1975, p. 290/291).

Tal processo se refletiu na recuperação do setor como elemento importante na dinâmica econômica regional, evidenciada pela envergadura dos novos investimentos, pela ampliação da capacidade instalada da indústria açucareira e pelo incremento das safras e do preço da terra nas regiões canavieiras nordestinas (Melo, 1975, p. 290/291).

Embora São Paulo, Pernambuco, Alagoas e Rio de Janeiro, nesse momento, fossem os maiores produtores de cana-de-açúcar (Szmrecsányi, 1979, p. 45), e a comercialização do açúcar continuasse a ser um dos mais importantes componentes, ou até o mais importante, no caso nordestino, o produto interno bruto estadual e a participação relativa do Nordeste se viram reduzidas. Entre as safras de 1930/1931 e 1973/1974, a participação nordestina teve uma queda de 67,9\% para $28,7 \%$, enquanto no Centro-Sul, no mesmo período, essa participação teve o aumento de 32,1\% para 71,3\% (Melo, 1975, p. 21,115). 
Entre os municípios brasileiros, na safra de 1971/1972, Campos, no Rio de Janeiro, era o que mais produzia açúcar: 301.505 toneladas, a partir de 3.447.137 toneladas de cana moída. Era seguido por Sertãozinho, em São Paulo, com a produção de 170.431 toneladas, a partir de 1.751.667 toneladas de cana moída. Dessa forma, constata-se, nessa época, a diferença de rendimento industrial ${ }^{12}: 87,5 \mathrm{~kg} /$ tonelada, no primeiro caso, e de $95,9 \mathrm{~kg} /$ tonelada no segundo. Araraquara, por exemplo, embora fosse o $5^{\circ}$ município maior produtor de açúcar, tinha um rendimento de $100 \mathrm{~kg} /$ tonelada, enquanto Barreiros, em Pernambuco, 78,4 kg/tonelada (Szmrecsányi, 1979, p. 147).

Como os preços pagos aos produtores eram inferiores aos valores médios das exportações, formou-se um grande saldo no Fundo Especial de Exportação, administrado pelo IAA, o que propiciou o financiamento de programas de modernização da agroindústria canavieira, tais como o Programa de Racionalização da Agroindústria Açucareira, posteriormente denominado de Programa de Apoio à Agroindústria Açucareira, e o Programa Nacional de Melhoramento da Cana-deAçúcar (Planalsucar).

O Programa de Racionalização da Agroindústria Açucareira se constituiu na verdade de um conjunto de normas, estabelecidas por meio da Lei 5.564/1971, do DL 1.186/1971 e dos atos do IAA (Quadro 5 ), que reformularam e revogaram algumas das antigas regras relativas à produção de açúcar no país.

Com essas medidas, o valor total da produção nacional de açúcar se alterou para 6 milhões de toneladas, cujo limite poderia ser modificado por decisão do ministro da Indústria e Comércio conforme as necessidades do mercado interno e externo (Szmrecsányi, 1979, p. 295). O cálculo da cota de produção total passava a ser feito pelo somatório das cotas das usinas situadas nas regiões Norte/Nordeste e Centro-Sul, em vez de ser tomado como base o somatório dos limites dos estados produtores (Szmrecsányi, 1979, p. 296).

Por meio do Decreto-Lei ${ }^{0}$ 1.186/1971, foram revogados dispositivos do Estatuto da Lavoura Canavieira e oferecidas as condições ne-

\footnotetext{
${ }^{12}$ Rendimento industrial equivale à quantidade de cana moída/kg de açúcar produzido.
} 
cessárias aos usineiros para o alcance de maior produtividade e para a redução de custos de produção por meio da concentração empresarial, o que se daria pela absorção de cotas de outras usinas e de fornecedores e pela relocalização de estabelecimentos agroindustriais em que a ecologia e a infraestrutura fossem mais favoráveis (Szmrecsányi, 1979, p. 298). O DL determinava ainda que só poderiam se beneficiar dos financiamentos as usinas que tivessem cotas oficiais iguais ou superiores a 24 mil toneladas de açúcar/safra.

Quadro 5. Atos do IAA complementares à Lei 5.654/1971.

\begin{tabular}{|l|l|}
\hline Normas & Pontos principais \\
\hline Ato IAA 19/1971 & $\begin{array}{l}\text { São canceladas as inscrições de 43 usinas, 36 no N/NE e sete no Centro-Sul, que } \\
\text { não produziam e não tinham condições de voltar a operar. }\end{array}$ \\
\hline Ato IAA 20/1971 & $\begin{array}{l}\text { Estabelecimento de critérios para a revisão de cotas de produção das usinas } \\
\text { para as safras de 1971/1972 e 1973/1974. }\end{array}$ \\
\hline Ato IAA 21/1971 & $\begin{array}{l}\text { Estabelecimento de critérios para as revisões das cotas de produção de açúcar } \\
\text { das usinas a partir da safra de 1974/1975. As cotas das usinas que apresentas- } \\
\text { sem rendimento industrial (kg de açúcar/ton de cana moída) superior à média } \\
\text { da respetiva região geoeconômica deveriam ter aumento proporcional das suas } \\
\text { média, cujas cotas seriam reduzidas no triênio seguinte. }\end{array}$ \\
\hline Ato IAA 22/1971 & $\begin{array}{l}\text { Estabelecimento da cota de 36 milhões de sacos para usinas do N/NE e de cerca } \\
\text { de 64 milhões para as do Centro-Sul. }\end{array}$ \\
\hline
\end{tabular}

Fonte: SZMRECSÁNYI, 1979, p. 297-298. Org.: dos autores, 2015.

Diante desse novo marco legal, iniciaram-se as transferências e fusões de usinas. Ao estabelecer que as cotas de fornecimento que não pudessem ser aproveitadas nas fusões, incorporações e relocações de usinas poderiam ser indenizadas e transferidas aos usineiros ou fornecedores de cana que arcassem com a indenização, houve a máxima facilitação para as transferências de cotas agrícolas (Szmrecsányi, 1979, p. 298-301) e para a sua concentração nas mãos de grandes usinas e proprietários.

Nessa mesma época, o IAA foi autorizado a cancelar a inscrição de usinas e de engenhos turbinados ou de açúcar bruto que tivessem paralisado sua atividade industrial durante três safras consecutivas a partir da safra de 1968/1969 (Szmrecsányi, 1979, p. 296/301). 
A procedência da matéria-prima utilizada na indústria era mais ou menos equilibrada entre fornecedores e usinas, com a preponderância dessas últimas. Em 1975, o número de usinas somava cerca de 200 estabelecimentos, enquanto o de fornecedores, $42 \mathrm{mil}$, a maioria pequenos produtores, vinculados às usinas pelas chamadas "cotas de fornecimento". Entre os fornecedores, a maior parte da cana era provida por aqueles que possuíam maiores cotas (superiores a 1.00o toneladas), ficando para os outros $91,8 \%$ o fornecimento de $48,7 \%$ da produção restante (Szmrecsányi, 1979, p. 50-51/53).

A maior parte da cana era absorvida pelas usinas ou destilarias de álcool. Nas áreas onde essas indústrias não estavam presentes, era utilizada como forragem e para a fabricação de rapadura ou aguardente (Szmrecsányi, 1979, p. 46-47). As usinas produziam dois tipos de açúcar: o demerara, denominado raw sugar no mercado internacional, destinado à exportação; e o cristal, in natura ou refinado, direcionado ao consumo interno (Szmrecsányi, 1979, p. 53).

As refinarias de açúcar geralmente se localizavam nos centros urbanos, próximas aos mercados consumidores. Havia também, em menor número, as refinarias anexas às usinas, mas a maior parte do açúcar refinado consumido no país era produzida pelas refinarias autônomas. Esse cenário se modificou em 1974, com a aquisição do controle acionário da Cia. União dos Refinadores pela Copersucar. Já proprietária de refinarias nos estados de São Paulo e Rio de Janeiro, tornou-se a partir desse momento a maior refinaria do país (Szmrecsányi, 1979, p. 82).

A produção de álcool, de forma diversa, era feita em destilarias que ficavam acopladas às usinas de açúcar. Produzia-se álcool de dois tipos: o álcool anidro, utilizado quase totalmente para fins carburantes, e o álcool hidratado, destinado para fins domésticos. Praticamente todo o álcool era residual, ou seja, um subproduto do açúcar, resultante do seu melaço. Como a maior parte da cana moída era destinada à produção de açúcar e não à industrialização de álcool direto, e como quase todo o melaço era exportado, a oferta de álcool no mercado interno não cresceu na mesma proporção do que a de açúcar (Szmrecsányi, 1979, p. 49), fazendo com que, em junho de 1975, a capacidade instalada das destilarias se tornasse ociosa. 
Quanto às exportações, o ano de 1975 marcou o término de um período de grande euforia no comércio exterior de açúcar. O excesso de especulação do preço do açúcar no início da década; a redução do consumo nos países importadores, que passaram a utilizar adoçantes de milho ou outros substitutos; e a previsão do aumento da produção de açúcar de cana-de-açúcar e de beterraba fizeram com que o período de intenso comércio externo de açúcar findasse (Szmrecsányi, 1979, p. 307/308).

Assim, após o açúcar apresentar, desde o final da década de 1960, uma curva ascendente, alcançando o seu valor máximo, cerca de US\$ 1.400/ton., em novembro de 1974, o seu comércio passou a apresentar uma queda vertiginosa, permanecendo no patamar de US\$300/ton., a partir do início de 1976 (Szmrecsányi, 1979, p. 93), mantendo-se assim até os dias de hoje.

Aliado a isso, em 1973, a crise de petróleo mundial fez com que seu preço no mercado internacional, em torno de US\$2,91/barril, fosse quadruplicado. Considerando que $80 \%$ do petróleo utilizado no país era importado, a sua compra implicava um dispêndio de US\$ 8,6 bilhões, causando um grave desequilíbrio nas contas externas nacionais (Shikida, 1998, p. 34). Nesse novo cenário, o álcool voltou a despertar o interesse do governo e da iniciativa privada (Szmrecsányi, 1979, p. $308 / 310)$.

\subsection{Uma nova crise, uma nova saída: o Proálcool}

Em meados da década de 1970, uma nova política para o álcool tomou corpo, aglutinando empresários de usinas e de destilarias, o Estado, o setor de máquinas e equipamentos do setor canavieiro e a indústria automobilística, dando origem ao Programa Nacional do Álcool - Proálcool (Szmrecsányi, 1979, p. 308; Shikida, 1998, p. 36).

Desde o Governo Getúlio Vargas, iniciativas haviam sido tomadas para o estímulo da produção alcooleira, mas sempre com o objetivo de sanear o mercado açucareiro e de dar destinação à superprodução canavieira ou de açúcar. No entanto, na década de 1970, a maioria das destilarias brasileiras operava com capacidade ociosa. O custo da gasolina era menor do que o custo para a produção do álcool anidro e do 
álcool hidratado, sendo muito mais vantajosa a produção de açúcar e a exportação do melaço do que a sua utilização na fabricação de álcool residual. Mesmo iniciativas para a utilização do álcool hidratado como matéria-prima em processos industriais de grandes empresas, como da Companhia Pernambucana de Borracha Sintética - Coperbo e da Union Carbide, haviam sido infrutíferas, sendo este substituído pelos derivados de petróleo (Szmrecsányi, 1979, p. 309).

As destilarias centrais do IAA se apresentavam ociosas da mesma forma, provocando a sua transferência para a iniciativa privada, como foi o caso da Destilaria Central de Santo Amaro (BA) e das destilarias centrais de Alagoas e Jacques Richer (RJ), em 1973 (Szmrecsányi, 1979, p. 309).

O aumento da produção de álcool só se efetivou de fato a partir de 1975, quando as exportações de açúcar voltaram a ser gravosas e a crise do petróleo instaurou-se no país. A partir desse momento, observa-se a intensificação da modernização capitalista no setor (Andrade, 1994, p. 236) e detecta-se um novo período na indústria canavieira, caracterizado por uma política orientada para o fortalecimento da produção de um novo produto derivado da cana-de-açúcar - o etanol.

Fazendo-se um breve parêntese, álcool é a denominação genérica do composto orgânico constituído por oxigênio e hidrogênio ligado a um átomo de carbono. A sua denominação varia conforme a sua composição química. Dessa maneira, caso possua um átomo de carbono, é denominado etanol; caso possua duas moléculas de carbono, de metanol, e assim por diante.

Dentre os álcoois, o etanol, ou álcool etílico, é o mais importante devido às suas várias aplicações: em combustíveis, produtos de limpeza, bebidas e aditivos em perfumes, desodorantes, dentre outros usos. Para cada um desses usos, a graduação alcóolica é diferenciada, podendo, no Brasil, ser apresentada de três formas: porcentagem em volume (\% Vol), grau Gay-Lussac ( ${ }^{\circ} \mathrm{GL}$ ) e grau do Instituto Nacional de Peso e Medidas ( ${ }^{\circ}$ INPM).

Em termos de uso como combustível, o álcool etílico, ou etanol, é empregado como aditivo na gasolina (etanol anidro) ou como combustível propriamente dito (etanol hidratado), podendo ser fabricado 
a partir de várias matérias-primas, como a cana-de-açúcar, beterraba e mandioca. Para ser classificado como etanol anidro, deve ter graduação alcóolica superior a 99,3 $3^{\circ} \mathrm{INPM}\left(98 \% \mathrm{Vol}\right.$ ou $\left.{ }^{\circ} \mathrm{GL}\right)$, e como etanol hidratado, de $92,5^{\circ}$ a $96,5^{\circ}$ INPM $\left(94,5^{\circ}\right.$ a $96,3 \%$ Vol ou $\left.{ }^{\circ} \mathrm{GL}\right)$, especificações essas que são determinas na Resolução no 19/2015 da ANP (Agência Nacional Do Petróleo, 2015).

Assim, o Proálcool foi criado, em 1975, com o objetivo de incentivar a produção de álcool combustível "através da expansão da oferta de matérias-primas, com especial ênfase no aumento da produtividade agrícola, da modernização e ampliação das destilarias existentes e da instalação de novas unidades produtoras, anexas a usinas ou autônomas, e de unidades armazenadoras" (Brasil, 1975, Art. $2^{\circ}$ ).

É importante esclarecer que a orquestração de interesses governamentais e privados oportunamente corroborou a alternativa álcool combustível como a opção energética mais adequada para a substituição de derivados de petróleo, sobrepujando outros programas, como o de óleos vegetais, de florestas energéticas, entre outros. Outros programas haviam sido aventados para a substituição de alguns derivados do petróleo juntamente com o Proálcool, como o Proóleo, procurando substituir o óleo diesel, e o Procarvão, para substituir o óleo combustível. Claro que tecnicamente o álcool podia estar melhor posicionado que o óleo e o carvão vegetais em termos de fonte alternativa de energia (Shikida,1998, p. 34/49), mas o governo poderia ter considerado outras opções.

Na sua primeira fase, a da implementação, o Proálcool surgiu, dessa forma, como uma alternativa energética e como a solução para a crise do açúcar nacional no mercado mundial, incentivando, sobretudo, a produção do álcool anidro para ser adicionado à gasolina. $\mathrm{O}$ direcionamento principal do programa foi o aproveitamento da capacidade ociosa das destilarias anexas às usinas de açúcar existentes. Para tanto, o governo federal lançou mão de uma série de instrumentos que basicamente consistiam na paridade dos preços do álcool com o açúcar, na garantia de compra do produto pela Petrobras e na criação de linhas de crédito subsidiadas para projetos vinculados ao programa, tanto do setor agrícola como do industrial. Cerca de US\$ 1 bilhão foi investido 
no período de 1975 a 1980, sendo um quarto de recursos privados e três quartos de recursos públicos, com o Estado tomando para si o risco do investimento (Santos, 1987, p. 6; Shikida, 1998, p. 39/42).

Os estados que mais se beneficiaram nesse período foram aqueles mais capitalizados e que tinham uma tradição na produção açucareira, havendo instalado em épocas anteriores destilarias anexas, como foi o caso de São Paulo e Alagoas, seguidos por Pernambuco e Rio de Janeiro, conforme demonstrado na Tabela 10 (Shikida, 1998, p. 42; Bray, 2000, p.58).

Tabela 10. Número de projetos de destilarias anexas e autônomas aprovadas pelo Conselho Nacional do Álcool - Cenal (1975-1979).

\begin{tabular}{|c|c|c|c|}
\hline Estado & Destilarias anexas & Destilarias autônomas & Total \\
\hline São Paulo & 64 & 23 & 87 \\
\hline Alagoas & 22 & 8 & 30 \\
\hline Pernambuco & 19 & 3 & 22 \\
\hline Rio de Janeiro & 11 & 1 & 12 \\
\hline Paraná & 1 & 9 & 10 \\
\hline Minas Gerais & 7 & 2 & 9 \\
\hline Paraíba & 3 & 4 & 7 \\
\hline Mato Grosso do Sul & o & 6 & 6 \\
\hline Rio Grande do Norte & 2 & 2 & 4 \\
\hline Goiás & 1 & 3 & 4 \\
\hline Ceará & 1 & 2 & 3 \\
\hline Sergipe & 2 & 1 & 3 \\
\hline Espírito Santo & 1 & 2 & 3 \\
\hline Bahia & 1 & 1 & 2 \\
\hline Mato Grosso & 1 & 1 & 2 \\
\hline Amazonas & o & 1 & 1 \\
\hline Pará & o & 1 & 1 \\
\hline Maranhão & $\mathrm{O}$ & 1 & 1 \\
\hline Piauí & o & 1 & 1 \\
\hline Santa Catarina & o & 1 & 1 \\
\hline
\end{tabular}

Fonte: BRAY, 2000, p.59. Org.: dos autores, 2015. 
Com essa distribuição geográfica de subvenções governamentais, mantinha-se a estrutura tradicional da agroindústria açucareira por meio da ampliação das plantas industriais nos estados tradicionalmente produtores de açúcar (Shikida, 1998, p. 41).

Após o segundo choque do petróleo, a partir de 1979, iniciou-se a segunda fase do Proálcool, seu período mais dinâmico, que teve como principal objetivo a expansão da implantação de destilarias autônomas para a produção de álcool hidratado para combustível de veículos automotores em substituição à gasolina (Shikida, 1998, p. 47). Preocupado com a pouca repercussão do Proálcool, o governo criou o Conselho Nacional do Álcool - CNAL e a Comissão Executiva Nacional do Álcool - Cenal (Decreto n. 83.700/1979), que aceleraram a aprovação dos projetos de destilarias a serem instaladas no país (Andrade, 1994, p. 236).

Estimulado pelo segundo choque no preço do petróleo, provocado pela guerra entre os dois grandes produtores mundiais, Irã e Iraque, o governo brasileiro estabeleceu a meta de produção de 10,7 milhões de metros cúbicos (10,7 bilhões de litros) de álcool, a ser atingida em 1985. O programa continuou com a política de crédito subsidiado para a instalação das destilarias autônomas; reduziu a alíquota do Imposto sobe Produtos Industrializados (IPI) e da Taxa Rodoviária Única (atual IPVA) para veículos privados movidos a álcool; estabeleceu o limite de 65\% do preço do álcool hidratado em relação ao preço da gasolina ao consumidor; e determinou a obrigatoriedade de adicionamento de $22 \%$ de álcool anidro à gasolina (Shikida, 1998, p. 48).

Em 1985, o número de destilarias autônomas (59\% dos estabelecimentos) ultrapassou o de destilarias anexas $(54,2 \%)$, as quais foram as responsáveis pela expansão da produção de álcool, tendo em vista a impossibilidade de ampliação da capacidade produtiva das destilarias anexas (Shikida, 1998, p. 52; Santos, 1987, p. 19; Andrade, 1994, p. 237).

Apesar do estabelecimento de critérios para o registro de unidades produtoras de álcool hidratado, com capacidade de produção de até 5 mil litros/dia (Decreto-Lei 85.698/1981), só foram aprovados pelo Proálcool projetos de destilarias com capacidade produtiva igual ou superior a 60 mil litros/dia, alegando-se ser esta a capacidade mínima 
economicamente viável. Propostas para a implantação de minidestilarias não foram viabilizadas, o que indica o caráter concentrador do programa (Bray, 2000, p. 64).

Desde a década de 1950, pesquisas para o desenvolvimento de um motor automotivo que utilizasse álcool hidratado como combustível único estavam sendo realizadas pelo professor e pesquisador Urbano Ernesto Stumpf (USP/UnB/ITA). Como resultado, em 1979, foi lançado o primeiro automóvel brasileiro com motor movido a etanol - o Fiat 147. Em setembro desse mesmo ano, o governo e a Associação Nacional de Fabricantes de Veículos Automotores Anfavea assinaram um protocolo estabelecendo metas mínimas de produção de veículos a álcool e de conversão anual de motores para esse combustível (Shikida, 1998, p. 48-49), fazendo com que a proporção de venda desses veículos passasse de $28,5 \%$, em 1980, para 96\%, em 1985 (Shikida, 1998, p. 54).

Durante essa fase, pesquisas sobre outras variedades de cana mais produtivas e mais adaptadas às condições climáticas e pedológicas das áreas produtoras começaram a ser divulgadas, possibilitando o aumento do rendimento agrícola da cana-de-açúcar. A introdução, no início da década de 1980, dessas novas variedades coincidiu com a mudança na forma de pagamento da cana, que deixou de ser por tonelada e passou a ser por teor de sacarose e pureza do caldo, o que impulsionou ainda mais o aperfeiçoamento dos tratos agrícolas. Os ganhos em termos de produtividade com a introdução de variedades com elevado teor de sacarose, boa produtividade agrícola, rusticidade e adaptação a solos com baixa fertilidade permitiram que o rendimento agrícola médio de 46,5 de toneladas de cana por hectare, em 1974, alcançasse 63,3 toneladas de cana por hectare em 1982 (Shikida, 1998, p. 58/59).

Nesse contexto, o álcool adquiriu importância estratégica na economia nacional, sob duas formas complementares. Apresentando boas taxas de retorno aos investimentos no setor e ao mesmo tempo servindo como regulador de estoques, evitando a superprodução de açúcar nos momentos de queda dos preços no mercado internacional.

A possibilidade de destinação da cana-de-açúcar para a produção de álcool foi complementada pela elevação dos limites da proporção de 
etanol anidro na gasolina (Santos, 1987, p. 19), o que consequentemente aumentou a demanda de matéria-prima para a produção de álcool. Dessa forma, como observou Santos (1987, p.19), "A criação de uma válvula de escape para o setor açucareiro [foi] o objetivo (não explícito) do Proálcool de maior êxito".

Nesses dois períodos do Proálcool, portanto, ocorreu o aumento progressivo da destinação da cana-de-açúcar para a produção alcooleira, em detrimento da produção açucareira (Tabela 11).

Tabela 11. Destinação da cana moída no Brasil entre as safras de 1977/1978 a 1984/1985 (em 1.000 toneladas)

\begin{tabular}{|c|c|c|c|c|}
\hline Safra & Produção para álcool & $\%$ & Produção para açúcar & $\%$ \\
\hline $1977 / 78$ & 3.457 & 3,3 & 101.176 & 96,7 \\
\hline $1978 / 79$ & 17.301 & 15,8 & 92.413 & 84,2 \\
\hline $1979 / 80$ & 32.608 & 27,8 & 84.717 & 72,2 \\
\hline $1980 / 81$ & 37.813 & 28,6 & 94.249 & 71,4 \\
\hline $1981 / 82$ & 42.205 & 31,7 & 91.081 & 68,3 \\
\hline $1982 / 83$ & 64.675 & 38,8 & 101.981 & 61,2 \\
\hline $1983 / 84$ & 92.856 & 46,9 & 105.149 & 53,1 \\
\hline $1984 / 85$ & 96.679 & 47,9 & 105.137 & 52,1 \\
\hline
\end{tabular}

Fonte: SHIKIDA, 1998, p. 56. Org.: dos autores, 2015.

Após 1986, o Proálcool entrou em um terceiro período, caracterizado pela sua crise (Santos, 1987, p. 6; Bray at alii, 2000, p. 56-57; Shikida, 1998, p. 33; Vian, 2003, p.84-96). Após atingir o seu auge em termos de recursos investidos, entre 1979 e 1985, observou-se, a partir de 1986, a redução gradual da participação do governo no Proálcool, com a suspensão dos financiamentos e subsídios para novas destilarias (Shikida, 1998, p. 63). Ocorreu a desaceleração da expansão das áreas colhidas com cana-de-açúcar, que, no período anterior, havia chegado a uma taxa de $8,7 \%$ ao ano, e que em meados da década de 1980 alcançou apenas o crescimento de o,6\% ao ano (Shikida, 1998, p. 64). 
Outro fator a ser considerado foi o desvio da destinação da cana, antes direcionada para a produção do álcool, para a produção do açúcar para exportação, atingindo, em 1994, 3.402.191 toneladas; em 1995, 5.917,871 toneladas; e em 1998, 9.364.247 toneladas, incluindose o açúcar demerara, o cristal e o refinado (Bray, 2000, p. 72; Távora, 2011, p. 22).

Nos anos de 1990, a dissolução da União Soviética e, consequentemente, do seu mercado preferencial suprido principalmente por Cuba, provocou o aumento do valor do açúcar no mercado externo. Além disso, com o preço do petróleo abaixo daquele atingido na década de 1980, o álcool não era mais um produto interessante para a indústria, a qual passou a dar preferência à fabricação do açúcar.

Assim, as instabilidades na produção de álcool, devido à falta de incremento no plantio dos canaviais e à destinação da cana à produção açucareira, provocaram desequilíbrios entre a oferta e a demanda de álcool, ocorrendo a partir da safra 1986/1987 a carência no abastecimento principalmente de álcool hidratado. Tal desequilíbrio acabou por causar a necessidade de sua importação em 1989 (Tabela 12), o que se tornou um contrassenso em relação ao objetivo do Proálcool, que era exatamente a redução da importação de petróleo a fim de economizar as divisas do país (Shikida, 1998, p. 63).

Além da falta de álcool nos postos de combustível em várias cidades, presenciou-se muita desconfiança em relação à qualidade do motor a álcool, tendo em vista o seu pequeno desenvolvimento tecnológico, o que prejudicava, por exemplo, a partida do carro nos períodos de inverno (Távora, 2011, p. 22). Conjuntamente, a queda vertiginosa do preço da gasolina, o aumento gradativo do preço do álcool hidratado em relação ao da gasolina (em 1979, 64,5\%, em meados da década de 90, 80\%), e a redução do IPI fizeram com que o consumidor voltasse a preferir, no final da década de 1980, o carro à gasolina (Shikida, 1998, p. 70/71).

A redução da compra de carro a álcool refletiu-se na indústria automobilística. Nos primeiros quatro anos da década de 1980, a venda de carro a álcool havia ultrapassado a casa dos 90\% do volume total da venda de carros produzidos no Brasil. No último ano da década de 1980, 
essa participação se reduzira, a ponto de chegar em 1994 a 12,25\% e, em 1995, a 3,6\% (Shikida, 1998, p. 64/65/70/71).

Tabela 12. Produção e consumo de álcool anidro e hidratado no Brasil, 1985/1986 a 1995 (milhões de litros).

\begin{tabular}{|c|c|c|c|c|c|c|}
\hline $\begin{array}{c}\text { Safra ou } \\
\text { ano }\end{array}$ & $\begin{array}{c}\text { Produção } \\
\text { de anidro }\end{array}$ & $\begin{array}{c}\text { Produção de } \\
\text { hidratado }\end{array}$ & $\begin{array}{c}\text { Total de } \\
\text { produção } \\
\text { de álcool }\end{array}$ & $\begin{array}{c}\text { Consumo } \\
\text { de anidro }\end{array}$ & $\begin{array}{c}\text { Consumo } \\
\text { de hidra- } \\
\text { tado }\end{array}$ & $\begin{array}{c}\text { Total de } \\
\text { consumo de } \\
\text { álcool }\end{array}$ \\
\hline $1985 / 1986$ & $3.200,00$ & $8.621,00$ & $11.821,00$ & $2.212,60$ & $6.761,70$ & $8.974,30$ \\
\hline $1986 / 1987$ & $2.163,10$ & $8.352,90$ & $10.516,00$ & $2.426,10$ & $8.760,30$ & $11.186,40$ \\
\hline $198719 / 88$ & 1.983 & $9.470,20$ & $11.453,20$ & $2.012,00$ & $8.982,10$ & $10.994,10$ \\
\hline $1988 / 1989$ & $1.725,90$ & $9.987,30$ & $11.713,20$ & $1.973,60$ & $10.128,30$ & $12.101,90$ \\
\hline $1989 / 1990$ & $1.451,70$ & $10.429,20$ & $11.880,90$ & $1.332,50$ & $10.614,80$ & $11.947,30$ \\
\hline $1990 / 1991$ & $1.288,50$ & $10.494,00$ & $11.782,50$ & $1.872,50$ & $9.899,80$ & $11.772,30$ \\
\hline $1991 / 1992$ & $1.986,80$ & $10.765,30$ & $12.752,10$ & $1.756,20$ & $10.031,20$ & $11.787,40$ \\
\hline 1992 & $1.986,80$ & $10.729,40$ & $12.716,20$ & $1.899,00$ & $9.630,70$ & $11.529,70$ \\
\hline 1993 & $2.216,40$ & $9.480,60$ & $11.697,00$ & $2.548,30$ & $9.404,40$ & $11.952,70$ \\
\hline 1994 & $2.522,60$ & $8.763,00$ & $11.285,60$ & $2.850,40$ & $9.665,10$ & $12.515,50$ \\
\hline 1995 & $2.869,10$ & $9.837,70$ & $12.706,80$ & $3.367,80$ & $9.722,00$ & $13.089,80$ \\
\hline
\end{tabular}

Fonte: SHIKIDA, 1998, p. 63. Org.: dos autores, 2015.

Nesse contexto, de 1986 até a safra de 1991/1992, várias unidades produtoras de açúcar e álcool pararam suas atividades. A maioria, $71,6 \%$, localizada no Centro-Sul, e apenas $28,4 \%$ no Norte/Nordeste. O maior número, 82,1\%, eram destilarias autônomas, em grande parte não tradicionais do setor, e sim indústrias que haviam se beneficiado dos subsídios estatais da segunda fase do Proálcool (Shikida, 1998, p. 89/91). Nesse mesmo período, duas cooperativas, a Coperflu e a Copaminas, foram liquidadas, e apenas a Copersucar, apesar da heterogeneidade tecnológica de suas afiliadas, encontrava-se em boa posição (Shikida, 1998, p. 88).

Com a crise, sem a continuidade do apoio governamental e sem haver investido na tecnologia necessária para o aumento da produtivi- 
dade, muitas das empresas sucroalcooleiras não tinham outro caminho a não ser encerrar suas atividades (Shikida, 1998, p. 91). Por outro lado, alguns empresários mais dinâmicos optaram por aplicar parte de seu capital em maior desenvolvimento tecnológico. Foi o caso das usinas São Martinho, da Barra e Santa Elisa, localizadas em São Paulo. Como a produção de álcool etílico a partir de cana-de-açúcar era genuinamente um processo industrial brasileiro, tais inovações tecnológicas foram sendo desenvolvidas, experimentadas e implementadas conforme se ia aprendendo e verificando seus resultados na planta industrial e na lavoura (learning-by-doing). A inserção dessas novas tecnologias possibilitou a redução nos custos de produção e o alcance de maior produtividade, permitindo a continuidade das suas atividades, mesmo em um momento de crise (Shikida, 1998, p. 80).

Mas a derrocada do Proálcool havia acirrado antigas rivalidades entre o Centro-Sul e o Norte/Nordeste e colocado em maior evidência as suas diferenças, que, além das relacionadas à capacidade produtiva, envolviam a capacidade de organização dos usineiros.

Portanto, uma das principais questões que começou a emergir nesse período foi o aparecimento da necessidade de autogestão do complexo canavieiro, pautada na tentativa da estruturação de entidades representativas que pudessem de certa forma substituir a ação reguladora do Estado. Foi um processo bastante conturbado, tendo em vista as entidades existentes até então não possuírem a representatividade necessária para a promoção de um consenso, agrupando interesses muito variados de usineiros e fornecedores de cana.

No Centro-Sul, a crise detonada pelo Proálcool fez com que fosse fundada, em 1992, a Associação das Indústrias de Açúcar e Álcool do Estado de São Paulo (AIAA), um verdadeiro braço político da Copersucar. No Norte/Nordeste, os usineiros buscaram a sua representatividade na esfera política para a manutenção de privilégios locais, como a equalização de custos e a reserva de mercado (Shikida, 1998, p. 75).

A desregulamentação ocorreu gradativamente. Desde 1987, o governo proibira a utilização de recursos do Tesouro Nacional na comercialização de açúcar para fins de exportação, o que só poderia ser rea- 
lizado, a partir de então, por pessoas jurídicas ou físicas (Decretos-Lei 2.401/1987 e 2.437/88). Em 1988, a promulgação da nova Constituição Federal sublinhou a função do Estado como regulador e planejador das atividades econômicas, deixando para trás o seu papel intervencionista, e incentivou ao mesmo tempo o caráter da livre concorrência da economia nacional (Shikida, 1998, p. 70).

A partir de 1990 esse movimento iria ser sentido com maior ênfase no setor. Com o início do Governo Collor de Mello (1990-92), tevese a instauração de uma política neoliberal orientada para a racionalização da máquina estatal, por meio da redução dos incentivos e subsídios governamentais, pelo aumento das privatizações, pela extinção e/ou fusão de várias instituições públicas.

Nesse contexto, o IAA foi extinto em 1990. Suas atribuições foram transferidas para a Secretaria de Desenvolvimento Regional - SDR (Shikida, 1998, p. 68), que passou a ser o órgão responsável pelas questões da produção do álcool, do açúcar e da cana. Foi criado ao mesmo tempo o Departamento Nacional de Combustíveis (DNC), responsável pela distribuição do álcool e dos derivados de petróleo.

Em 1991, foi publicada a Lei $n^{0} 8.178$, base legal para a liberação de preços do setor sucroalcooleiro e que conferiu ao ministro da Economia, Fazenda e Planejamento o poder de "baixar, em caráter especial, normas que liberem, total ou parcialmente, os preços de qualquer setor" (Brasil, 1991, Art. $3^{\circ}$, Inciso III).

Com a extinção do IAA, as exportações de açúcar, que antes eram de sua competência exclusiva, foram privatizadas, e as pesquisas agronômicas realizadas pelos pesquisadores do Planalsucar passaram, em parte, a ser desenvolvidas nas universidades, onde parcela dos funcionários havia sido admitida (Shikida, 1998, p. 69).

Apesar da extinção do IAA, algumas práticas reguladoras se mantiveram, como as cotas de produção, o planejamento de safra e a permissão para a implantação de novas destilarias e usinas, que ficavam agora a cargo da SDR, bem como os subsídios para os produtores do Norte/Nordeste (Shikida, 1998, p. 69).

Em 1993, já havia sido aberto o mercado de distribuição de combustíveis, antes monopolizado pelas grandes distribuidoras, sur- 
gindo a partir de então numerosas novas distribuidoras, que passaram de oito, no início da década de 1990, para 169, em 1999 (Moraes, 2000, p. 95).

No Governo Fernando Henrique Cardoso (1995-2002), a economia brasileira começou a ser saneada, conseguindo-se controlar a inflação graças ao Plano Real, e o Brasil voltou a crescer. A visão neoliberal ganhou mais força e foi realizada uma ampla reforma no Estado (Schwarcz e Starling, 2015, p. 503).

Foram criados, em 1997, a Agência Nacional do Petróleo, em substituição ao Departamento Nacional de Combustíveis (DNC), e o Conselho Interministerial do Açúcar e do Álcool (Cima), presidido pelo Ministério de Ciência e Tecnologia (MCT) até 1999, quando passou para o Ministério da Agricultura, Pecuária e Abastecimento (Mapa). O objetivo principal do Cima relacionava-se à formulação de políticas para o setor sucroalcooleiro visando à participação dos produtos da cana-de-açúcar na Matriz Energética Nacional, à autossustentação do setor, ao desenvolvimento técnico e científico e, no ato da sua criação, à atenção com os impactos ambientais e sociais, o que foi retirado na sua revisão de 2000 (Decreto 3,456/2000; decreto de 21 de agosto de 1997). O álcool voltava a ter importância no planejamento energético brasileiro, mas sem as subvenções dos governos anteriores.

Depois de 1997, várias portarias do Ministério da Fazenda (Portarias no 294/1997, no 110/98, no 102/1998 e nº 275/1998) determinaram a liberação dos preços do álcool anidro, da cana-de-açúcar, do açúcar cristal standard e do mel residual (melaço), marcando o início de uma nova fase, caracterizada pela livre concorrência empresarial.

Paralelamente, novas tecnologias e novos procedimentos foram sendo introduzidos para o alcance de uma maior produtividade e de um menor custo de produção dos dois produtos tradicionais - açúcar e álcool -, mas também para o aproveitamento de resíduos que, aos poucos, iam se transformando em novos subprodutos da cadeia produtiva canavieira, como a vinhaça, a torta de filtro e o bagaço de canade-açúcar. A indústria sucroalcooleira começava a se reinventar, como será visto no capítulo 5 . 


\subsection{Mais avanços tecnológicos no período do Proálcool}

Ao final da década de 1960, os valores de venda do açúcar brasileiro exportado estavam abaixo dos seus custos de produção e de comercialização. Para deixar de ser um produto gravoso e conseguir trazer divisas para o país, era necessária a redução dos custos e a elevação da produtividade açucareira.

Com esse objetivo, em 1966, a convite do IAA, o geneticista Albert J. Mangelsdorf visitou todos os centros produtores de açúcar no país, "fazendo observações e colhendo subsídios para elaboração de um relatório propondo a criação de um programa de pesquisa agronômica, com vistas à elevação dos rendimentos da cultura canavieira" (Szmrecsányi, 1979, p. 290/291). Seu relatório, publicado em 1967, foi a base para a criação do programa de melhoramento da cana-de-açúcar, tanto do IAA como da Cooperativa Central de Produtores de Açúcar e Álcool (Copersucar) em São Paulo (Szmrecsányi, 1979, p. 291; Olalde, 1992, p. 62).

Como consequência, três anos depois da visita de Mangelsdorf, o IAA criou, no estado de São Paulo, o Laboratório Agroindustrial de Piracicaba e a Estação Experimental de Cana-de-Açúcar de Araras. Ao laboratório foram designadas as funções de análises químicas de álcool, do açúcar e de outros derivados da cana e análises de solo, de fertilizantes e foliar. A Estação Experimental ficou com a responsabilidade de produzir novas variedades de cana-de-açúcar e de pesquisar inovações no âmbito das práticas culturais, tais como mecanização agrícola, irrigação, uso de herbicidas, adubação, dentre outras (Szmrecsányi, 1979, p. 292). Ao mesmo tempo, o IAA instituiu outra estação experimental, em Alagoas, onde foi autorizado o desenvolvimento de um plano piloto de pesquisas com variedades de cruzamentos de várias espécies de cana-de-açúcar (Szmrecsányi, 1979, p. 292).

No mesmo sentido, a Copersucar, percebendo que a letargia tecnológica prejudicava a competitividade sucroalcooleira paulista externa e internamente, estimulou que o seu Centro de Tecnologia investisse no estudo de novas variedades e novos processos de produção, mantendo a assistência técnica para os problemas que pudessem advir das 
inovações para suas 70 usinas e cinco destilarias autônomas associadas (Abarca, 1999, p. 2).

Essas ações, até então pontuais, foram ampliadas, em 1970, com a criação do Programa Nacional de Melhoramento da Cana-de-Açúcar (Planalsucar). O objetivo do Planalsucar era a implantação e o desenvolvimento "de projetos de pesquisa nos campos da genética, fitossanidade e agronomia, com o objetivo de obter novas variedades de cana-de-açúcar, ecologicamente especializada e de elevado índice de produtividade agrícola e industrial" (Azzi, 1974, p. 13 apud Szmrecsányi, 1979, p. 294).

Foram instaladas estações agronômicas nas regiões açucareiras, agrupadas em quatro coordenadorias com sedes em Araras (SP), Campos (RJ), Rio Largo (AL) e Carpina (PE), e um Centro de Estudos Especiais, onde ficava a Superintendência do Planalsucar, em Piracicaba (Szmrecsányi, 1979, p. 294).

O desenvolvimento das pesquisas e das novas técnicas promovidas, sobretudo pelo Planalsucar, viabilizou o surgimento de um novo produto derivado da cana - o etanol hidratado para uso como combustível; de um novo motor adaptado ao uso do etanol; bem como das destilarias autônomas.

Apesar de o álcool ser misturado à gasolina desde os anos de 1930, o seu uso como combustível só foi se dar 45 anos depois, quando o contexto político e econômico possibilitou essa mudança e quando o conhecimento científico permitiu o estágio de maturidade que seria alcançado em 1980.

A extinção do IAA, em 1990, e consequentemente do Planalsucar, no Governo Fernando Collor de Melo, sem nenhum planejamento prévio (Andrade, 1994, p. 233-234), resultou no término de importantes pesquisas desenvolvidas pelo programa, que dentre outras contribuições havia levado ao desenvolvimento de variedades de cana-de-açúcar sob a sigla RB.

Para não se perder todo o processo de pesquisa de melhoramento da cana-de-açúcar, foi criada, em 1991, a Rede Interuniversitária para o Desenvolvimento do Setor Sucroenergético (Ridesa), inicialmente formada por um convênio entre sete universidades federais (UFPR, UFSCar, UFV, UFRRJ, UFS, UFAL e UFRPE), onde alguns dos pesqui- 
sadores do IAA haviam sido admitidos, tendo sido absorvidas nela também a infraestrutura das sedes das antigas coordenadorias e estações experimentais.

No ano de 2015, a Ridesa integrou mais outras três universidades federais - UFG, UFMT e UFPI - e 80 estações experimentais, já tendo sido lançadas 59 variedades adotadas em cerca de $70 \%$ dos estados canavieiros do país.

No setor agrícola, apesar de a indústria de colheitadeiras ter sido implantada no Brasil desde 1966, impulsionada pela produção de soja do Sul do país, apenas com o advento da $2^{\mathrm{a}}$ fase do Proálcool foram desenvolvidas colheitadeiras especiais para a cana-de-açúcar, comercializadas na década de 1980 pela Massey Ferguson, pela Santal Equipamentos S. A. e pela Toft Equipamentos (Amato Neto, 1985, p. 61).

No entanto, o preço proibitivo dessas máquinas para os agricultores, em torno de duas e meia a três vezes o valor de um trator de porte médio (Amato Neto, 1985, p. 61), fez com que continuassem a ser empregados os trabalhadores volantes na colheita da cana-de-açúcar. As colheitadeiras só seriam amplamente generalizadas no Brasil nos anos 2000, em parte devido à imposição de leis ambientais, que proibiram o uso da queima dos canaviais, tornando ilegal o uso de mão de obra humana para a colheita em grande parte dos canaviais.

A transformação dos processos produtivos tanto na parte agrícola como industrial permitiu que, desde os anos de 1950, a agroindústria canavieira se constituísse em um complexo agroindustrial formado por usinas, refinarias de açúcar e destilarias de álcool (Szmrecsányi, 1979, p. 48-49). A continuidade dos avanços tecnológicos fez com que simultaneamente a agricultura canavieira se vinculasse à indústria de máquinas e insumos e à indústria processadora/beneficiadora de matéria-prima agrícola (Müller, 1989, p. 61-62), originando o denominado agronegócio canavieiro.

A denominação agronegócio se deve a John Davis e Ray Goldberg, que em meados dos anos de 1950 nomearam como agrobusiness (agronegócio) esse conjunto de atividades "que abarcam a manufatura e a distribuição de insumos para a unidade produtiva agrícola; as operações produtivas na unidade agrícola em si; e o armazenamento, proces- 
samento e distribuição dos produtos agrícolas e de seus subprodutos" (Müller, 1989, p. 46).

O estágio do processo de tecnificação do agronegócio canavieiro foi examinado no início da década de 1990 pelo Instituto de Pesquisa Econômica Aplicada (Ipea), que realizou uma pesquisa com empresas líderes de setores-chave da economia brasileira, dentre eles a agroindústria do açúcar e do álcool. Apesar de ser um estudo amostral concernente às três maiores empresas paulistas, responsáveis por 6,4\% do álcool e 9,2\% do açúcar produzido no país durante a safra de 1990/1991, dão uma ideia do estágio tecnológico do setor na época (Furtado, 1994, p. 75).

$\mathrm{Na}$ fase agrícola, as empresas apresentaram importantes avanços. A maior delas se deu pela introdução de novas variedades de canade-açúcar, com maior teor de sacarose, mais adaptadas a solos pobres e com período de safra mais prolongado, garantindo o incremento da produtividade no campo. Para a colheita, foi introduzido o "rastelo rotativo", que carregava a cana cortada, disposta no chão, até o caminhão. O uso desse equipamento possibilitou a redução do teor de impurezas quando comparado à carregadeira convencional. Além disso, aumentou em 10\% o rendimento da mão de obra no corte e fez com que a lavagem da cana, antes de ser processada, não fosse mais necessária, o que antes representava uma redução entre $2 \%$ a $4 \%$ na perda de açúcar (Furtado, 1994, p. 75/76).

Outra novidade foi o início do uso da vinhaça como fertilizante. Extremamente rica em potássio, verificou-se que se constituía em excelente adubo para as plantações (Furtado, 1994, p. 76).

$\mathrm{Na}$ fase industrial, foram desenvolvidos equipamentos periféricos, introduzidos desde o fim da década de 1970 e começo dos anos de 1980, que incrementaram a produção nas usinas, tais como: mesas alimentadoras de $45^{\circ}$; picadores e desfibradores; sistemas de alimentação da moenda por gravidade; "rolo de pressão" ou $4^{\circ}$ rolo da moenda (Furtado, 1994, p. 77).

Tais modificações permitiram nas empresas analisadas o aumento do coeficiente de sacarose extraído da cana, que na safra de 1978/1979 girava em torno de 90,3\% indo para 95,8\% na safra de 1985/1986. A 
produtividade industrial passou de 29,5 mil toneladas/dia para 40,5 mil toneladas/dia. Em relação à fermentação, pesquisas desenvolvidas nos laboratórios industriais possibilitaram o controle do processo por batelada, aumentando a eficiência dessas usinas de 75\% para 90,5\%. Na destilação do álcool, introduziu-se a "safenação", que consistia na ligação entre duas colunas de destilação para a obtenção de quantidade de álcool hidratado muito superior à capacidade habitual. $\mathrm{O}$ ganho em uma das empresas analisadas foi de $64 \%$, enquanto em outra foi de 80\% (Furtado, 1994, p. 77)

A pesquisa do Ipea constatou que os centros tecnológicos e as estações de melhoramento das empresas foram os grandes responsáveis pela maior parte do desenvolvimento e da difusão dessas inovações, apesar de apresentarem ainda plantas industriais tradicionais, sendo que o centro nevrálgico da pesquisa e desenvolvimento (P\&D) do setor estava centrado no centro tecnológico da Copersucar, em São Paulo. Esse centro, na época de pesquisa, tinha recursos em torno de US\$20 milhões. Dispunha de um quadro de profissionais altamente qualificados, sendo que dos 148 empregados de nível superior, 21 eram mestres e 11 doutores (Furtado, 1994, p. 78).

Algumas das inovações eram oriundas de outros países e foram adaptadas pelas empresas ao contexto brasileiro, como foi o caso dos equipamentos periféricos, cujos modelos eram da África do Sul (Furtado, 1994, p. 75/76).

Ficou nítido também que o desenvolvimento tecnológico se pautou nos subsídios oferecidos pelo Plano de Modernização e Racionalização e pelo Proálcool, que havia favorecido o crescimento rápido do setor, mas insuficientemente planejado (Furtado, 1994, p. 77).

\subsection{A geografia canavieira nas três primeiras fases do Proálcool}

A cana-de-açúcar no início da década de 1970 já era cultivada em ambos os hemisférios, até aproximadamente $35^{\circ}$ de latitude, atingindo uma média anual de 620 milhões de toneladas (Szmrecsányi, 1979, p. 57). Apesar de os maiores países plantadores de cana estarem localizados nos continentes americano e asiático, apenas 60\% da pro- 
dução mundial de açúcar era derivada da cana-de-açúcar. O restante era derivado da beterraba, fortemente cultivada nos EUA e na URSS (Szmrecsányi, 1979, p. 57).

Embora a Índia fosse o maior produtor mundial de cana-de-açúcar, mais de $40 \%$ da sua produção era processada de forma artesanal, ou seja, sem centrífugas. Dessa forma, o Brasil apresentava-se como o maior produtor mundial de açúcar centrifugado, só sendo superado pelo açúcar de beterraba da URSS (Szmrecsányi, 1979, p. 58 a 63).

No início da década de 1970, São Paulo era o maior produtor, tanto em termos de área como em termos de produção, seguido por Pernambuco, Alagoas, Rio de Janeiro e Minas Gerais. Para se ter uma ideia, a produção paulista de açúcar na safra de 1974/1975 foi responsável por quase metade $(49,8 \%)$ da produção brasileira, superando a do Nordeste como um todo. Era no Centro-Sul que as usinas estavam concentradas, aproximadamente $57 \%$, e era também nessa região onde as de maior porte estavam localizadas, nos estados de São Paulo e Paraná (Szmrecsányi, 1979, p. 66/76).

O Proálcool teve grande êxito em São Paulo, onde foram construídas 78 destilarias no período 1975-1985. A cana-de-açúcar passou a ocupar os melhores solos, substituindo as outras culturas concorrentes, mas coexistindo com as áreas de pastagens, uma vez que parte dos usineiros era também criadora de gado. Em São Paulo, a região mais dinâmica foi a de Ribeirão Preto, onde se organizaram os maiores complexos agroindustriais canavieiros do país e onde se utilizaram as mais recentes inovações tecnológicas do setor (Andrade, 1994, p. 61-62/64).

A superioridade paulista em relação aos demais estados explicase, como já salientado anteriormente, em parte, pelas condições físicas - relevo, solos e clima, favoráveis ao cultivo e à mecanização da cultura canavieira; e, em parte, pela infraestrutura existente, que facilitava o transporte da matéria-prima, do produto final e a sua comercialização (Szmrecsányi, 1979, p. 72). Além disso, era em são Paulo que estavam localizados os maiores centros de pesquisa da cana, como o Centro Tecnológico da Copersucar, a Escola Superior de Agricultura Luiz de Queiros (Esalq) e as principais indústrias de máquinas e equipamentos 
para a agroindústria canavieira, como a Dedini, a Codistil e a Zanini (Shikida, 1998, p. 60).

Até meados de 1950, Pernambuco havia sido o maior produtor brasileiro de açúcar, quando foi ultrapassado por São Paulo, e três décadas depois, em pleno desenvolvimento do Proálcool, por Alagoas (Tabela 13). O Proálcool favoreceu enormemente o estado alagoano, onde o uso dos tabuleiros possibilitava a expansão dos canaviais, subsidiando, entre os anos de 1975 e 1990, a instalação de 20 novas destilarias anexas e nove autônomas, o que provocou o aumento em 25 vezes da produção de álcool, a duplicação da produção de açúcar e a triplicação da área cultivada com cana-de-açúcar no estado. Assim, Alagoas tornou-se, desde os anos de 1980, o segundo maior produtor e exportador de açúcar e, até 1992, também de álcool (Carvalho, 2002, p. 263).

Tabela 1. Área colhida/plantada (ha) nos dez estados brasileiros maiores produtores (1979-1980).

\begin{tabular}{|c|c|c|}
\hline Estado & $1979^{1}$ & $1980^{2}$ \\
\hline São Paulo & 947.750 & 1.088 .480 \\
\hline Pernambuco & 365.969 & 345.285 \\
\hline Alagoas & 329.500 & 349.059 \\
\hline Rio de Janeiro & 194.137 & 201.791 \\
\hline Minas Gerais & 181.010 & 222.295 \\
\hline Paraíba & 97.490 & 108.310 \\
\hline Bahia & 75.180 & 76.958 \\
\hline Paraná & 60.000 & 59.887 \\
\hline Ceará & 54.143 & 54.508 \\
\hline Rio Grande do Sul & 45.117 & 49.523 \\
\hline
\end{tabular}

Fontes: ${ }^{1}$ IBGE, 1979, p. 360; ${ }^{2}$ UNICADATA. Org.: dos autores, 2019.

Na segunda fase do Proálcool, quando a inserção da tecnologia foi maior, a diferenciação entre as regiões Norte/Nordeste e Centro-Sul se fez mais presente (Shikida, 1998, p. 60), principalmente após 1986, 
durante a crise do Proálcool, quando o rendimento agrícola da canade-açúcar (kg/ha) no Centro-Sul foi 20\% superior ao das outras regiões do país, o mesmo acontecendo em termos industriais na produção de açúcar e álcool.

\subsection{A desregulamentação do setor sucroalcooleiro e os impactos na geografia canavieira}

A partir da década de 1990, a agroindústria canavieira entrou em uma nova fase, com o desdobramento do processo de desregulamentação do setor e uma série de modificações nas estratégias de produção e comercialização, que por sua vez foram materializadas nos territórios influenciados direta ou indiretamente por essas transformações. Podese considerar que a década de 1990 se constituiu em um período de transição, marcada por uma grande crise e ao mesmo tempo por um grande dinamismo da agroindústria canavieira (Vian, 2003, p. 96/98), que determinou as suas novas características a partir de então.

Após o longo período de intervencionismo estatal, não havia consenso no setor sobre qual regulamentação deveria existir, por quem deveria ser conduzida e de que forma (Vian, 2003, p. 111). Várias eram as possibilidades para a expansão da capacidade produtiva, como a diversificação da produção açucareira e a cogeração de energia elétrica, mas todas dependiam de investimentos em tecnologia e pesquisa, bem como de financiamento. Com a sucessão de normas para a desregulamentação, sem a presença e a mediação do Estado, e sem o necessário amadurecimento do setor em relação a essas alternativas que se colocavam para o seu avanço, foram sendo tomadas decisões fragmentárias pelas empresas de acordo com a sua localização geográfica, suas ligações políticas e seus interesses imediatos.

Ao Estado coube atuar de modo indireto, como indutor das ações realizadas pelas empresas, investindo na infraestrutura de transporte, concedendo créditos, sobretudo via BNDES, e estruturando as políticas públicas necessárias (Camelini e Castillo, 2012, p. 10).

Um dos principais impactos da desregulamentação foi a descentralização da produção canavieira. Na safra de 1990/9191, os seis maiores produtores, em ordem decrescente de importância, eram os estados 
de São Paulo, Alagoas, Pernambuco, Minas Gerais, Rio de Janeiro e Paraíba (Tabela 14).

Tabela 14. Área de plantio da cana-de-açúcar nos dez estados brasileiros maiores produtores e nas regiões Centro-Sul e Norte-Nordeste, 1990.

\begin{tabular}{|c|c|}
\hline Estado & Área (ha) \\
\hline São Paulo & 1.811 .980 \\
\hline Alagoas & 561.217 \\
\hline Pernambuco & 473.726 \\
\hline Minas Gerais & 301.710 \\
\hline Rio de Janeiro & 206.786 \\
\hline Paraíba & 160.294 \\
\hline Paraná & 159.420 \\
\hline Goiás & 106.826 \\
\hline Bahia & 80.302 \\
\hline Mato Grosso do Sul & 67.921 \\
\hline [...] & {$[\ldots]$} \\
\hline Total Região Centro-Sul & 2.810 .895 \\
\hline Região Norte-Nordeste & 1.511 .404 \\
\hline
\end{tabular}

Fonte: UNICADATA Org.: dos autores, 2019

Com a crise do Proálcool e o início da desregulamentação do setor, nos anos de 1990, a produção de vários estados, como Rio de Janeiro e Paraíba, foi ultrapassada pela dos que apresentavam condições mais competitivas no mercado. Esse foi o caso do Paraná, um dos estados que mais ganhou participação ao longo da década de 1990, devido ao impulso dado pela então Associação de Álcool do Paraná (Alcopar) e pelo governo do estado, incentivando o cultivo da cana-de-açúcar (Vian, 2003, p. 114/115). Dessa forma, ao final da década de 1990, o Paraná já se estabelecia como o terceiro estado com maior plantio de cana-de-açúcar do Brasil, sendo ultrapassado apenas por São Paulo e Alagoas, posição essa que seria modificada apenas nos anos 2000, quando Minas Gerais se apresentou como o segundo estado com maior extensão canavieira.

Desde 1975, o governo federal vinha implementando programas 
de incentivo para a produção e ocupação do cerrado, como o Programa de Desenvolvimento da Região do Centro-Oeste - Polocentro, que abrangia a construção de estradas, silos, armazéns, o desenvolvimento de pesquisa agropecuária, de assistência técnica e de extensão rural. Apesar de ter se iniciado com a intenção da produção de grãos e de carne, as técnicas de melhoramento de solos e a instalação da infraestrutura deram a base necessária para o amplo desenvolvimento da agroindústria canavieira, sobretudo na década de 1990, na segunda fase do Proálcool. Junto com o baixo preço das terras, o clima estacional e as condições planas de relevo de amplas áreas, tornaram os estados dessa região importantes produtores de cana-de-açúcar.

A indústria sucroalcooleira não era concentrada nos estados do Centro-Oeste, expandindo-se desde o Norte em área de floresta amazônica - município de Porto dos Gaúchos e Santa Terezinha -, onde domina o clima equatorial úmido, até municípios localizados nas proximidades de Cuiabá e na divisa com Goiás, nas margens do Rio Araguaia/ Barra do Garças. Assim, ora os solos ocupados eram arenosos, onde predominava o cerrado, ora eram argilosos ou aluviais dos rios da Bacia Amazônica (Andrade, 1994, p. 136).

A maioria das usinas, nos três estados, pertencia a grupos econômicos de São Paulo e do Nordeste, sendo em grande parte o álcool produzido comercializado no Sudeste e o açúcar consumido pelo próprio mercado regional (Andrade, 1994, p. 135).

Goiás possuía certa tradição canavieira, ligada a pequenos engenhos, formados desde o início do século XX, contabilizados, em 1935, em cerca de 1.402 engenhos. A canalização dos subsídios do Proálcool para Goiás fez com que, "na safra de 1984/85, estivessem em funcionamento 18 destilarias, sendo duas no atual estado de Tocantins. Em 1983, o crescimento da produção de álcool se deu com tal intensidade que Goiás se colocou como segundo produtor brasileiro, com 11,9\%, suplantado apenas por São Paulo, que produziu 34,25 do álcool nacional, ficando o Paraná em terceiro lugar, com 11,3\%” (Andrade, 1994, p. 130).

Em 1990, Goiás tinha em operação duas usinas e 15 destilarias de álcool, que o tornaram, na safra de 1992/1993, o $6^{0}$ maior produ- 
tor de álcool do país. Apesar da sua pequena produção açucareira, as destilarias se distribuíam por vários municípios, tanto na Bacia do rio Paranaíba, quanto na Bacia do Araguaia (Andrade, 1994, p. 127). De forma semelhante, os estados de Mato Grosso e Mato Grosso do Sul, que até 1977 eram um único estado, tornaram-se importantes produtores de cana-de-açúcar e de álcool.

Apesar de São Paulo manter-se como principal produtor de canade-açúcar, áreas tradicionais do estado, como Piracicaba e Campinas, apresentaram uma expansão menor do que as áreas do Oeste e Noroeste paulistas. O Planalto Ocidental Paulista, com colinas amplas, apresentava condições propícias para a expansão do cultivo da cana-de-açúcar, que passou a substituir a pecuária de corte nas regiões de Araçatuba e de São José do Rio Preto, onde haviam sido instaladas as primeiras destilarias autônomas de álcool. Na região de Ribeirão Preto, áreas anteriormente ocupadas pela agricultura anual e pela pecuária leiteira, como Guaíra, Batatais, Cajuru, Ipuã, Ituverava, Morro Agudo e Igarapava, também foram substituídas pela cana-de-açúcar (Vian, 2003, pp. 116119). Dessa forma, apesar de todas as incertezas derivadas da crise do Proálcool, essas regiões apresentaram um incremento acima de 40\% na década de 1990 (Tabela 15).

Tabela 15. Taxa de crescimento da moagem da cana-de-açúcar em novas e tradicionais regiões paulistas canavieiras durante a década de 1990.

\begin{tabular}{|c|c|}
\hline Regiões produtoras & Evolução (\%) \\
\hline São José do Rio Preto & 76,2 \\
\hline Presidente Prudente & 75,6 \\
\hline Araçatuba & 70,5 \\
\hline Assis & 47,2 \\
\hline Ribeirão Preto & 41,8 \\
\hline Campinas & 30,3 \\
\hline Araraquara & 26 \\
\hline Piracicaba & 18,6 \\
\hline
\end{tabular}

Fonte: VIAN, 2003, p. 118. Adaptado pelos autores, 2015. 
O açúcar sempre fora, juntamente com o café, um dos produtos brasileiros mais regulamentados na economia brasileira, e o setor sucroalcooleiro sempre estivera sob o controle de uma rede de instituições e normas estatais. Desenvolvido sob a proteção estatal, o setor sucroalcooleiro nordestino não se encontrava preparado para enfrentar o ambiente competitivo que se impôs a partir da década de 1990 (Carvalho, 2002, p. 269).

$\mathrm{O}$ resultado foi que no decorrer de todo o processo de desregulamentação, a participação do Centro-Sul foi aumentando em detrimento da produção nordestina. Tradicionais estados canavieiros, como Pernambuco, Alagoas e Paraíba, que haviam mantido produção de destaque desde meados da década de 1950, não conseguiam acompanhar, ao final do século XX, as estratégias agressivas de produção e comercialização de açúcar e álcool do estado de São Paulo e de outros estados do Centro-Sul, para onde pendiam favoravelmente as condições econômicas e biofísicas.

Possuindo boas condições edafoclimáticas, relevos com declividades mais baixas, maior produtividade agrícola e industrial, proximidade com os maiores mercados consumidores do país e um grande centro tecnológico de pesquisa agronômica, o Centro de Tecnologia Canavieiro (CTC), que aglutinava cerca de 600 profissionais e um orçamento anual de 35 milhões de reais, aplicados por 35 empresas sucroalcooleiras paulistas associadas (Carvalho, 2002, p. 270), o Centro-Sul cada vez mais foi se posicionando como a região sucroalcooleira mais importante do Brasil.

Somado a isso, as safras nordestinas de 1993/1994 e 1998/1999 foram fortemente prejudicadas por anos de seca, que atingiram até mesmo regiões tradicionalmente úmidas, como a Zona da Mata pernambucana (Andrade, 2001, p. 267). Outro aspecto a considerar foi a política recessiva do governo, com restrição de crédito às empresas nordestinas até então beneficiadas, o que provocou uma grave crise financeira no setor canavieiro (Andrade, 2001, pp. 274-276).

Isso resultou no fechamento de 35 usinas e destilarias no Nordeste, ou seja, 31\% das unidades nordestinas, entre as safras de 1991/1992 e 1999/2000, deixaram de operar, enquanto, no Brasil, no 
mesmo período, esse índice foi menor que $17 \%$. Em relação à produção entre as safras de 1994/1995 a 2000/2001, o Centro-Sul apresentou crescimento de $5,47 \%$, enquanto no Norte/Nordeste a quantidade de cana produzida se reduziu 4,1\%. Parte da explicação para essa redução deve-se à redução da produção pernambucana, que chegou a um índice de 20\% em determinados anos ao longo desse período (Lima e Sicsú, 2002, p.292).

Ao longo das últimas décadas do século $\mathrm{XX}$, mas sobretudo após a desregulamentação do setor, o complexo sucroalcooleiro em Pernambuco entrou em colapso, com o fechamento de muitas destilarias e usinas ou a transferência dos investimentos de grupos de usineiros pernambucanos para outros estados do Centro-Sul, principalmente Minas Gerais e estados do Centro-Oeste, que possuíam maior competitividade, seja pelas suas condicionantes naturais, seja pelos benefícios econômicos, sobretudo fiscais. Além disso, alguns usineiros diversificaram seus investimentos, aplicando seu capital em outras atividades econômicas como construção, hotelaria etc. (Andrade, 2001, p. 74; Lima e Sicsú, 2002, p.301).

Nas áreas mais aptas ao cultivo da cana-de-açúcar, foram sendo incorporadas as mudanças tecnológicas necessárias para o aumento da produtividade e o enfrentamento de um mercado que não mais apresentava os mesmos níveis de subsídios governamentais de antes. Nas áreas mais declivosas, ainda com o uso de modelos tradicionais de cultivo e, portanto, menos rentáveis, a cana foi paulatinamente sendo substituída por outros cultivares, tais como banana, acerola, seringueira, pupunha, bambu, mandioca, inhame, olerícolas, dentre outros, apesar de, após alguns anos, a dificuldade de comercialização e de financiamento fazerem com que algumas dessas experiências fossem abandonadas e a cana fosse reintroduzida (Lima e Sicsú, 2002, p.295/301).

Dessa forma, na década de 1990, presenciou-se, tanto em Pernambuco como na Paraíba, um processo de eliminação de canaviais, pertencentes tanto a fornecedores autônomos como a usinas e engenhos, o que também acabou por afetar a produção dos produtos do complexo sucroalcooleiro nesses estados (Vian, 2003, p. 273).

Em Alagoas, o complexo sucroalcooleiro, da mesma forma que 
em Pernambuco, havia se estruturado sob um modelo fortemente amparado pelo Estado. No entanto, diferentemente de Pernambuco, o novo ambiente institucional e a desregulamentação do setor levaram à sua total reestruturação e ao aumento da produção (Carvalho, 2002, p. 263).

Mesmo antes do Proálcool, Alagoas havia se beneficiado de investimentos estaduais e federais para a implantação de malha viária pavimentada e de rede elétrica para atendimento das unidades industriais da zona do açúcar. Com a crise do Proálcool, o setor buscou apoio financeiro irrestrito no governo estadual, o qual entrou em grave crise financeira estatal, a partir de 1996, devido à inadimplência de obrigações de R $\$ 40$ milhões devidas à Companhia Estadual de Eletricidade (Ceal), de R $\$ 76$ milhões de empréstimos vencidos ao banco estadual (Produban) e das transferências de 800 milhões de reais que o governo do estado havia feito para as usinas de açúcar, durante um período de 8 anos (Carvalho, 2002, p. 271).

Contudo, todos esses problemas não abateram a agroindústria canavieira alagoana, que continuou a expandir sua produção pautada nas empresas mais competitivas e nos grandes grupos empresariais familiares que passaram a adotar as mesmas estratégias do Centro-Sul. Investiram na produção de açúcar cristal superior, de açúcar refinado granulado e de mel rico. Iniciaram o aproveitamento da torta de filtro na adubação, da vinhaça na fertirrigação e do bagaço na cogeração de energia, o qual também era vendido às indústrias fabricantes de papel. Empresas que não conseguiram adotar essas novas estratégias foram desativadas e sua produção absorvida pelas que permaneceram no mercado (Carvalho, 2002, p. 272/278/281).

Assim, na safra de 1998/1999, mais de 90\% da produção sucroalcooleira alagoana estavam concentrados nas usinas Cachoeira, Caeté, Camaragibe, Coruripe, Guaxuma, Leão, Porto Rico, Roçadinho, Santa Clotilde, Santo Antônio, Seresta, Serra Grande, Sinimbu, Sumaúma, Triunfo e Uruba (Carvalho, 2002, p. 273), praticamente todas dos mesmos grupos econômicos familiares que detinham as destilarias: Carlos Lyra, Corrêa Maranhão, João Lyra, Toledo, Tércio Wanderley, Olival Tenório e Andrade Bezerra (Carvalho, 2002, p. 275). 
Da mesma forma que ocorreu em Pernambuco, alguns dos grupos empresariais, além de investirem nas usinas alagoanas, aplicaram parte de seus capitais em estados do Centro-Sul, sobretudo em Minas Gerais. Nesse estado, por exemplo, o Grupo Tércio Wanderley incorporou a Usina Iturama, no município do mesmo nome; o Grupo João Lyra, a usina Triálcool, em Ituiutaba; e o Grupo Carlos Lyra, a Usina Volta Grande, em Conceição de Alagoas, e a Usina Delta, em Delta. Ao mesmo tempo, passaram a aplicar também em outros setores, tais como pecuária (Grupo Olival Tenório), empresas de táxis aéreos (Grupos João Lyra e Carlos Lyra), fertilizantes (Grupo Tércio Wanderley), dentre outros (Carvalho, 2002, p. 279).

A irrigação continuou a ser realizada em Alagoas, contudo nos últimos anos da década de 1990, o aproveitamento da vinhaça na fertirrigação era evidente, apesar de em menor quantidade do que a água captada nos mananciais. Na safra de 1997/1998, dos 455.952 hectares plantados, 172.862 foram irrigados: $29.063 \mathrm{com}$ vinhaça, $38.038 \mathrm{com}$ água de lavagem e 105.759 com água limpa. Apesar de a mecanização haver sido introduzida nos anos de 1950, apenas algumas usinas a utilizavam no plantio e na colheita (Carvalho, 2002, p. 280)

Com a extinção do IAA e o fim do Planalsucar, os produtores de cana alagoanos passaram a utilizar variedades do Centro Tecnológico da Copersucar (CTC) - as variedades SP, cuja utilização dependia do pagamento de royalties, bem como as produzidas e melhoradas no próprio estado - as variedades RB (República do Brasil), por meio das pesquisas desenvolvidas pelo Programa de Melhoramento Genético da Cana-de-Açúcar (PMGCA), da Ridesa, nas subestações das usinas Caeté, Coruripe, Santo Antônio, Santa Clotilde e Serra Grande (Carvalho, 2002, p. 270/280).

Assim, ao se comparar os dados das safras de 1990/1991 e 2000/2001, percebe-se um decréscimo na produção canavieira de 23,1\% em Pernambuco, ao passo que, no mesmo período, em Alagoas, houve um aumento de 7,86\%. Em relação à produção de açúcar, a mesma tendência é evidenciada, com uma queda na produção pernambucana de aproximadamente $7 \%$, enquanto em Alagoas houve um aumento de $61,1 \%$, O único produto do complexo sucroalcooleiro que teve uma 
elevada queda, em ambos os estados, foi o álcool, que em Pernambuco teve uma redução de 74,9\%, e em Alagoas, de 42,3\%, reflexo da crise do Proálcool na década de 1990 (Tabela 16).

Tabela 16. Cultivo de cana-de-açúcar e produção de açúcar e álcool em Alagoas e Pernambuco, safras 1990/1991 e 2000/2001.

\begin{tabular}{|c|c|c|c|c|c|c|}
\hline \multirow{2}{*}{} & \multicolumn{3}{|c|}{ Safra 1990/91 } & \multicolumn{3}{c|}{ Safra 2000/o1 } \\
\cline { 2 - 7 } & $\begin{array}{c}\text { Cana-de-açúcar } \\
\text { (mil ton.) }\end{array}$ & $\begin{array}{c}\text { Açúcar } \\
\text { (mil ton.) }\end{array}$ & $\begin{array}{c}\text { Álcool } \\
\left(\mathrm{mil} \mathrm{m}^{3}\right)\end{array}$ & $\begin{array}{c}\text { Cana-de-açúcar } \\
\text { (mil ton) }\end{array}$ & $\begin{array}{c}\text { Açúcar } \\
\text { (mil ton.) }\end{array}$ & $\begin{array}{c}\text { Álcool } \\
\left(\mathrm{mil} \mathrm{m}^{3}\right)\end{array}$ \\
\hline Pernambuco & 18.679 & 1.194 & 1.194 & 14.367 & 1.111 & 300 \\
\hline Alagoas & 22.617 & 1.235 & 1.235 & 24.394 & 1.990 & 713 \\
\hline
\end{tabular}

Fonte: UNICADATA. Org.: dos autores, 2015.

Em Minas Gerais, a produção de álcool e de açúcar não apresentava uma grande importância no estado até os anos de 1970, devido à diversificação de sua economia, vinculada aos produtos minerários, à pecuária de corte e de leite e à produção de café e de grãos. Mas, com grande poder político, foi um estado bastante beneficiado pelas subvenções do Proálcool, o que estimulou a expansão dos canaviais. Além disso, a grande densidade demográfica do estado foi um fator favorável para o incremento da produção alcooleira a ser utilizada como combustível (Andrade, 1994, p. 80).

Assim, o estado que possuía, antes de 1975, 16 usinas em funcionamento, produzindo anualmente cerca de 360 mil toneladas de açúcar para um consumo no estado de 480 mil toneladas (Szmrecsányi, 1979, p. 78), passou, em 1990, a contar com cerca de 13 usinas de açúcar e 28 destilarias de álcool, indicando a expressiva quantidade de destilarias autônomas, a maioria localizadas no Triângulo Mineiro, tanto na Bacia do rio Grande como na do Paranaíba (Andrade, 1994, p. 77/84).

Os canaviais, que até os idos de 1970 estavam praticamente concentrados na Zona da Mata mineira, cuja relevo de morros e declividades acentuadas era desfavorável à mecanização (Szmrecsányi, 1979, p. 78), se expandiram para áreas do Triângulo Mineiro e Alto Paranaíba 
(Andrade, 1994, p. 77), onde o uso de adubos possibilitou o uso do relevo tabular, bastante adequado para a mecanização. Além disso, a inauguração de Brasília e a construção e melhoria de estradas foram fatores importantes, que permitiram a integração da parte setentrional mineira à sua capital e ao estado de São Paulo, o que facilitou o escoamento da produção das usinas e destilarias.

Assim, apesar do distanciamento da sua produção em relação aos estados de São Paulo, Alagoas e Pernambuco, e de não apresentar uma continuidade como no Nordeste Oriental ou em São Paulo, e nem concentração, como no estado fluminense, Minas Gerais possuía a quarta maior área de plantio de cana-de-açúcar em 1995.

O crescimento da produção açucareira de São Paulo, de Minas Gerais e do Paraná refletiram fortemente na produção fluminense, que com velhas usinas não tinha condições de competir (Andrade, 1994, p. 75). Com o Proálcool, grande parte da produção canavieira foi direcionada para as poucas destilarias autônomas instaladas em “Campos, São João da Barra, Conceição de Macabu, Macaé e Bom Jesus de Itapaboana” (Andrade, 1994, p. 73), e os produtores locais foram perdendo expressão diante de empresários vindos de outras regiões do país, como o grupo Othon Bezerra de Melo, de Pernambuco, que possuías três usinas no Norte fluminense - Barcelos, Cupim e Carapebus; Evaldo Inojosa, de Alagoas, que possuía a Usina Outeiro; e João Cleofas, também pernambucano, proprietário da Usina Sapucaia (Andrade, 1994, p. 76).

Apesar de ser o quarto maior estado plantador de cana-de-açúcar, em meados da década de 1970, paulatinamente o Rio de Janeiro foi perdendo importância para outros estados produtores de açúcar, produzindo na safra de 1992/1993 440 mil toneladas de açúcar e aproximadamente 200 milhões de litros de álcool (Andrade, 1994, p. 65), e se posicionando, em 1995, após o estado do Paraná em termos de hectares ocupados pela cana-de-açúcar (Tabela 17).

Na Bahia, a produção canavieira perdeu a relevância econômica que possuía desde o século XVI. Na safra de 1974/1975, a Bahia produziu apenas 665 mil sacos de açúcar de usina correspondente a um sétimo do consumo estadual, suprido pelas outras usinas do 
Norte/Nordeste. A produção baiana até então era dominada pelos engenhos tradicionais, espalhados pelo estado, mas com certo grau de concentração ao longo do Vale do São Francisco, e voltada à fabricação de aguardente e rapadura para o mercado local (Szmrecsányi, 1979, p. 80).

Tabela 17. Área plantada (ha) nos estados brasileiros maiores produtores (1995).

\begin{tabular}{|c|c|}
\hline Estado & 1995 \\
\hline São Paulo & 2.258 .900 \\
\hline Pernambuco & 471.272 \\
\hline Alagoas & 449.746 \\
\hline Minas Gerais & 267.571 \\
\hline Paraná & 255.767 \\
\hline Rio de Janeiro & 161.787 \\
\hline Paraíba & 152.435 \\
\hline Goiás & 115.073 \\
\hline Mato Grosso & 98.906 \\
\hline Bahia & 76.880 \\
\hline Mato Grosso do Sul & $75 \cdot 315$ \\
\hline Total Região Centro-Sul & 3.309 .951 \\
\hline Total Região Norte-Nordeste & 1.328 .330 \\
\hline Total Brasil & 4.638 .281 \\
\hline
\end{tabular}

Fontes: UNICADATA. Org.: dos autores, 2019.

Na safra de 1999/2000, a produção de açúcar e de álcool manteve-se concentrada na região Centro-Sul, nos estados de São Paulo e Paraná (Tabela 18). O Centro-Sul foi responsável pela produção de 11.604 milhões de $\mathrm{m}^{3}$ de álcool, enquanto o Norte/Nordeste, por 1.379 milhões de $\mathrm{m}^{3}$. O Centro-Sul produziu 16.900 milhões de toneladas de açúcar, enquanto o Norte/Nordeste produziu 2.487 milhões de toneladas (Unicadata). 
Tabela 18. Produção de açúcar e de álcool nos estados brasileiros maiores produtores (safra 1999/2000).

\begin{tabular}{|c|c|c|}
\hline Estado & Açúcar (mil toneladas) & Álcool total $\left(\mathrm{m}^{3}\right)$ \\
\hline São Paulo & 13.091 & 8.842 \\
\hline Paraná & 1.430 & 1.043 \\
\hline Alagoas & 1.215 & 551 \\
\hline Pernambuco & 856 & 340 \\
\hline Minas Gerais & 802 & 644 \\
\hline Mato Grosso & 485 & 544 \\
\hline Goiás & 369 & 118 \\
\hline Rio de Janeiro & 357 & 371 \\
\hline Mato Grosso do Sul & 320 & 71 \\
\hline Bahia & 145 & $1 . .]$. \\
\hline Total Brasil & {$[\ldots . .37983$} \\
\hline Total Região Centro-Sul & 16.900 & 11.604 \\
\hline & 2.487 & 12.983 \\
\hline
\end{tabular}

Fonte: UNICADATA. Org.: dos autores, 2019.

A agroindústria canavieira, antes caracterizada pela heterogeneidade de porte, de localização e de tecnologia, passou, assim, a partir da década de 1990, a ser caracterizada pela sua concentração produtiva espacial e pela centralização de capital sob a ordem de alguns grupos econômicos (Ramos, 2002, p. 248; Carvalho, 2002, p. 276) que possuíam o capital necessário para o emprego de alta tecnologia no campo e na indústria.

O fim dos subsídios governamentais, associado ao forte declínio de preços do açúcar e do álcool causados pela sua ampla oferta nos mercados nacional e internacional, acabou por culminar em uma crise de superprodução, ao final da década de 1990, levando muitas usinas à inadimplência e a um endividamento maior que $200 \%$ ao final da safra de 1999/2000 (Vian, 2003, p. 179), o que só seria revertido com o lançamento dos veículos com motores flex, em 2003. 
Dessa forma, ao findar do século $\mathrm{XX}$, a geografia canavieira era constituída por três grandes regiões produtoras: a paulista-paranaense, fundindo áreas historicamente importantes com áreas que adquiriram importância a partir do Proálcool; o Nordeste oriental, formado principalmente pelos estados de Alagoas e Pernambuco, segunda área produtora de açúcar no território nacional; e outra, constituída por Minas Gerais e estados do Centro-Oeste (Mato Grosso e Goiás), com espaços potenciais para se tornaram grandes produtores de açúcar e álcool, graças ao avanço da tecnologia agrícola, que permitiu o uso do solo coberto pelo cerrado.

\subsection{Impactos socioambientais causados pelo Proálcool}

A intensificação da produção de açúcar e de álcool fez com que impactos ocorridos anteriormente ganhassem maior intensidade e magnitude depois da década de 1970, sobretudo com a implantação do Proálcool.

Apesar da aquisição de antigos engenhos pelas usinas, os fornecedores se mantinham no século XX na cadeia produtiva da cana, tanto os antigos senhores de engenho como os pequenos lavradores. O Estatuto da Lavoura Canavieira, promulgado em 1941, havia favorecido a expansão das áreas cultivadas dos fornecedores durante as décadas de 1950 e 1960, fazendo com que até a safra de 1970/1971 a sua participação na matéria-prima processada pelas usinas fosse de 60\% em Pernambuco, 52,8\% em Alagoas e 57,1\% no Rio de Janeiro. Só em São Paulo, onde a maior parte da cana era cultivada nos terrenos da própria usina, é que a participação foi menor, cerca de 41,1\% (Andrade, 1994, p. 188).

A partir dos anos de 1970, no entanto, essa situação se modificou. O Programa de Apoio à Agroindústria Açucareira (1971) eliminou vários dispositivos do Estatuto da Lavoura Canavieira, fazendo com que a obrigatoriedade de recebimento pelas usinas de certa porcentagem de cana de fornecedores fosse gradativamente desconsiderada.

Assim, a partir de meados da década de 1970, a concentração, ou mesmo a superconcentração fundiária, ocorreu. Vários foram os motivos que levaram os usineiros e proprietários de destilarias a realizar a integração agroindustrial. Primeiro, a garantia de bom rendimento 
agrícola e do fornecimento contínuo da cana-de-açúcar, tendo em vista a grande demanda de matéria-prima suscitada com a implantação do Proálcool. Isso só foi possível com o uso dos recursos que esses empresários tinham disponíveis, advindos das facilitações do Proálcool, para investimentos em insumos e aquisição de novas variedades de cana mais produtivas.

Outro fator decisivo foi a obrigatoriedade do pagamento de ICMS - Imposto de Circulação sobre Mercadoria e Serviço na compra de cana de fornecedores, o que não ocorria se a cana fosse da própria usina, pois nesse caso não se configurava como uma operação de venda. Aos poucos, o arrendamento foi se tornando o processo mais vantajoso de produção da cana, pois além de não se pagar o ICMS, que era superior ao imposto pago no arrendamento, não havia a necessidade de se dispender grande soma de capital, como seria com a compra de uma propriedade rural (Andrade, 1994, p. 192-193)

Dessa forma, em 1975, em Pernambuco, por exemplo, da área total de 1.093 mil hectares da região canavieira, 495 mil, ou 45\%, pertenciam às usinas, sendo 30 o número de empresas proprietárias das 38 usinas em funcionamento no estado (Melo, 1975, p. 58). Na safra de 1986/1987, a quantidade de cana de fornecedores em Alagoas caiu para 42,1\%, e em São Paulo, para 30,4\%. Apenas no Rio de Janeiro, onde as usinas eram menos produtivas e o número de fornecedores muito grande, a porcentagem de cana fornecida era acima de 50\% (Andrade, 1994, p. 188-189)

Conforme alguns críticos do Proálcool da época, a concentração de terras para o cultivo da monocultura canavieira provocou em determinadas regiões a redução das áreas dedicadas ao plantio de alimentos de subsistência e à pecuária (Andrade, 1994, p. 141/238), prejudicando o abastecimento local e mesmo regional.

Em relação à força de trabalho, a usina se tornou um empreendimento que exigia grande eficiência para se manter no mercado. Para tanto, era necessária a contratação de profissionais de nível superior altamente qualificados, tais como engenheiros - agrônomos, químicos, mecânicos, eletricistas etc. - advogados, economistas, contadores, administradores de empresas, dentre outros. Além destes, para auxiliá-los 
na execução das atividades, eram admitidos profissionais de nível médio, formados como técnicos agrícolas, técnicos industriais, tratoristas, motoristas de caminhão (Andrade, 1994, p. 199). Os operários industriais moravam geralmente nas cidades próximas das usinas e destilarias ou algumas vezes em vilas operárias construídas por ocasião da instalação da usina (Andrade, 1994, p. 200).

Embora, nessa época, ainda persistisse o trabalhador boia-fria contratado principalmente para a fase da colheita, a maioria possuía carteira de trabalho, cujo intermediário (gato) nas regiões próximas das grandes usinas fora substituído por empreiteiras, que realizavam a intermediação entre o trabalhador e as usinas e as destilarias, ou pelo departamento de recursos humanos dessas empresas, que estabeleciam um contrato temporário de trabalho com os trabalhadores volantes (Andrade, 1994, p. 217).

Apesar das garantias trabalhistas de que passaram a usufruir, sobretudo na década de 1990, a contratação desses trabalhadores provocou impactos negativos importantes nas regiões de onde eram originários, pois eram afastados de suas pequenas propriedades para um trabalho que durava apenas de quatro a seis meses, o que estimulava muitas vezes o êxodo rural, de forma que eles empobreciam e se proletarizavam (Andrade, 1994, p. 238-239).

Mais preocupante ainda eram certas áreas canavieiras no Pará, na Bahia, no Maranhão, em Mato Grosso e em Mato Grosso do Sul, onde se encontravam trabalhadores, sobretudo nordestinos, em situação análoga à escravidão. Eles recebiam baixíssimos salários e muitas vezes tinham o aluguel e os alimentos descontados dos rendimentos. A fuga era praticamente impossível, pois os empresários mantinham jagunços armados para assegurar a permanência dos trabalhadores nas fazendas (Andrade, 1994, p. 217).

Nessa época, o trabalho de corte da cana baseava-se no eito, que era um retângulo formado por cinco ruas (linhas de plantio da cana) pelo comprimento, que era variável de acordo com a resistência física e a produtividade do cortador. O pagamento era feito ou pelo metro linear do comprimento do eito ou pela quantidade da cana cortada (Alves, 2006, p. 92). 
O corte manual iniciava-se com o emprego do fogo para a queima da palhada da cana, a fim de facilitar o corte. O trabalhador depois cortava a cana rente ao solo e a parte superior da cana, chamada ponteira, onde não há sacarose, e transportava a cana cortada em cada rua para a rua central, arrumando-a em montes (Alves, 2006, p. 92).

Estudo feito por Alves (2006) constatou que a produção média dos trabalhadores na década de 1950 era de três toneladas/dia, e nos anos de 1980, de seis toneladas/dia. Desde o final da década de 1990, é de 12 toneladas/dia, o que provocou e provoca imensos problemas ao trabalhador, podendo em alguns casos levá-los à morte.

Apesar da ocorrência desses problemas com os cortadores de cana, a sustentabilidade do Proálcool baseou-se predominantemente na geração de empregos, como se observa na Tabela 19, que apesar de se referir ao estado de São Paulo indica a tendência nacional em relação à elevação do número de trabalhadores volantes empregados no setor e à característica sazonalidade dessa empregabilidade (Guedes et alii, 2002, p. 312).

Tabela 19. Estimativa do número de trabalhadores volantes em São Paulo (1975, 1980 e 1986).

\begin{tabular}{c|c|c|c}
\hline Mês/ano & 1975 & 1980 & 1986 \\
\hline Fevereiro & 304.005 & 320.070 & 357.709 \\
\hline Abril & 334.162 & 292.799 & 439.974 \\
\hline Junho & 285.918 & & 341.796 \\
\hline Setembro & & 246.363 & \\
\hline Novembro & 225.968 & 254.538 & \\
\hline
\end{tabular}

Fonte: GUEDES et alii, 2002, p. 313. Org.: dos autores, 2015.

Após os anos de 1990, no período de crise do Proálcool, principalmente nos estados do Nordeste, o processo de eliminação e fechamento de usinas, destilarias e canaviais produziu forte impacto social. Trabalhadores, tanto do setor agrícola como industrial, ficaram desempregados, e em várias áreas, como na Zona da Mata meridional, o encerramento das atividades de usinas próximas umas às outras resultaram na concentração desses empregados nos centros urbanos ou 
na ocupação de antigas usinas e engenhos (Vian, 2003, p. 273). "Não dispondo de qualificação profissional, assistência alimentícia, higiênica ou cultural", parte dessa massa de desempregados "passa a viver de trabalhos ocasionais, de furto e de prostituição” (Andrade, 2001, p. 276).

Outros impactos que tiveram grande magnitude nesse período foram os relacionados aos aspectos físicos e bióticos das áreas onde as usinas e destilarias estavam instaladas. Graças aos incentivos governamentais provenientes do Proálcool e ao emprego de adubos e de novos cultivares, a agroindústria canavieira se expandiu por áreas antes naturalmente inviáveis.

Os canaviais alcançaram o Planalto Ocidental Paulista, o Triângulo Mineiro, Goiás e Mato Grosso, intensificando os impactos ainda mais no Domínio do Cerrado, cuja

região nuclear, ocupa predominantemente maciços planaltos de estrutura complexa, dotados de superfícies aplainadas de cimeira, e um conjunto significativo de planaltos sedimentares compartimentados, situados em níveis que variam entre 300 e $1700 \mathrm{~m}$ de altitude. As formas de terrenos são, grosso modo, similares tanto nas áreas de terrenos cristalinos aplainados como nas áreas sedimentares sobrelevadas e transformadas em planaltos típicos (Ab’Sàber, 2003, p. 117-118).

E onde

Os solos são profundos e bem drenados, predominando os latossolos vermelho-amarelos e argissolos vermelho-amarelos, muito lixiviados e predominantemente ácidos, com alta concentração de alumínio e ferro residuais e deficientes em nutrientes (Ross, 2006, p. 96).

Inicialmente, no Domínio do Cerrado, a cana-de-açúcar foi cultivada nos solos das planícies dos rios, como o Cuiabá e o Grande, ou de rios menores, voltada para a produção de cachaça ou rapadura em pequenos engenhos. Apenas com a introdução de técnicas de correção de acidez e de uso de fertilizantes, nos anos de 1970, é que os solos do cerrado puderam ser aproveitados agricolamente. Embora a cana-de- 
-açúcar tenha tido pouco efeito no desmatamento, haja vista extensas áreas de cerrado terem sido convertidas em outros usos anteriormente, apoiado grandemente por projetos de pecuária extensiva e de cultivo de grãos, o uso generalizado de agrotóxicos pode ter provocado impactos negativos de grande importância na biota e nos corpos hídricos.

O Proálcool provocou outro impacto de grande magnitude - o aumento da produção de vinhaça decorrente do incremento da produção de álcool. Em São Paulo, dois procedimentos eram utilizados para a sua destinação final: a aplicação em locais restritos, conhecidos como áreas de sacrifício, e a aplicação direta nas áreas de cultivo, como fertilizante (Guedes et alii, 2002, p. 315).

Na maioria dos casos, no entanto, a vinhaça era lançada diretamente nos corpos d'água. Mesmo quando utilizada como fertilizante, devido ao pequeno conhecimento para a sua adequada aplicação e à alta concentração, na época das chuvas acabava da mesma forma sendo carreada para os corpos d'água (Andrade, 1994, p. 238).

Considerando-se que para cada litro de álcool são produzidos em média 13 litros de vinhaça e que na safra de 1970/1971 foram produzidos 637.238 milhões de litros de álcool total, e em 1980, 3.706 milhões de litros, houve a geração de cerca de 8 e 48 milhões de litros de vinhaça, respectivamente. Isso significa que em uma década aumentou em cerca de seis vezes a produção de vinhaça, a qual era lançada diretamente em corpos d'água e em áreas de sacrifício ambiental. Ainda que de forma sazonal, no período da safra, provocava a morte de peixes e incômodo à população do entorno devido ao mau cheiro.

$\mathrm{O}$ uso das novas tecnologias que surgiram fez com que o processo de substituição da mão de obra humana pelas máquinas prosseguisse. Muitas das fases do cultivo da cana-de-açúcar, sobretudo nas grandes propriedades próximas aos polos canavieiros, eram realizadas plenamente por máquinas, como a adubação, a aplicação de herbicidas e, algumas vezes, ainda raras, a colheita. Novos modelos de colheitadeiras, que podiam ser utilizadas em áreas mais inclinadas, foram se desenvolvendo, sendo já admitido que uma única colheitadeira poderia substituir cerca de 60 trabalhadores.

Apesar das crises sucessivas, o setor sucroalcooleiro continuou a 
desfrutar de incentivos agroindustriais, que subvencionavam a cana e outras grandes monoculturas de exportação. Como sempre foi na história canavieira, o crédito continuou mais acessível aos grandes produtores e nem tanto aos pequenos. Era a denominada "Modernização Dolorosa" (Andrade, 1994, p. 235), que se propagou pelo país desde a segunda metade do século XX e continuou a sua trajetória rumo ao novo século. 


\section{CONTINUIDADES E DESCONTINUIDADES: A AGROINDÚSTRIA SUCROENERGÉTICA}

\subsection{A salvação da lavoura canavieira}

Passados 25 anos do início do Proálcool, a agroindústria sucroalcooleira enfrentava novamente uma grave crise e voltava-se à ideia da produção de etanol ${ }^{13}$ para conseguir sanar o mercado por meio da reativação do Proálcool. Após uma década de adversidades em relação ao preço comparativo do etanol com o da gasolina e da praticamente extinção da produção de carros a álcool, instaurou-se, assim, a sua quarta fase, a atual, que se caracteriza sobretudo pelas

ações corporativas, articulando cada vez mais segmentos econômicos, sociais e políticos, marcada pela liberação de preços dos produtos setoriais, introdução dos veículos flex fuel, possibilidades de aumento nas exportações de etanol e patamares de preços elevados, nos curto e médio prazos, de petróleo no mercado mundial (Veiga Filho e Ramos, 2006, p. 48).

De fato, em 1988, a Bosch, empresa americana, desenvolveu uma tecnologia que contava com um sistema de gerenciamento que, por meio de um sensor, detectava a mistura de combustível, a qual de-

\footnotetext{
${ }^{13} \mathrm{Na}$ tentativa de padronizar a nomenclatura para o padrão internacional para a promoção do biocombustível brasileiro no mercado externo, a ANP determinou uma nova denominação para o álcool, que passou a ser designado como álcool etílico ou etanol (anidro ou hidratado) (ANP, 2009).
} 
nominaram de flex fuel (Lima, 2009, p. 4). Com a crise do Proálcool e a consequente redução de vendas de carro a álcool, começou-se a refletir sobre a possibilidade do uso da tecnologia flex fuel como uma alternativa para a reativação do mercado brasileiro de álcool hidratado (Lima, 2009, p. 4).

A tecnologia foi apresentada a várias montadoras, e em 1992, a General Motors - GM iniciou o processo de adaptação de um Omega 2.o à gasolina para o uso da tecnologia flex fuel, cujo resultado final foi apresentado em 1994. Os trabalhos para a implementação da nova tecnologia continuaram a ser desenvolvidos, sendo construídos protótipos pela GM, Ford e Fiat, apesar do pouco apoio dos produtores de álcool, que não viam com bons olhos a novidade, já que a decisão para o uso do etanol ou da gasolina seria tomada pelo consumidor na hora do abastecimento (Lima, 2009, p. 4/5).

O incentivo necessário à sua fabricação foi dado em 2002, quando os veículos flex fuel foram inseridos na mesma categoria do carro a álcool para fins tributários (Lima, 2009, p. 5). Assim, em abril de 2003, foi lançado o primeiro veículo flex fuel no mercado nacional, um Gol Total Flex 1.6, da Volkswagen em parceria com a empresa Magneti Marelli. Logo após, no mesmo ano, foram lançados o Corsa Flexpower, da GM, e o Fiesta Flex-Fuel, da Ford (Lima, 2009, p. 5).

Desde então, a tecnologia flex fuel tornou-se preponderante, possibilitando a retomada da demanda e da produção do álcool hidratado. Entre os anos de 2003 e 2007, as vendas anuais de automóveis e veículos comerciais leves flex fuel aumentaram de 48 mil para aproximadamente 2 milhões de unidades, refletindo na instalação de 55 novas usinas, entre 2007 e 2008, e de 30 novas unidades em 2009 (Lima, 2009, p. 5; Neves e Trombin, 2014, p. 42).

A euforia pela nova fase do Proálcool era tanta que, em viagem a Mineiros (GO), em 2007, o presidente Luiz Inácio Lula da Silva (20032011), ao avaliar o resultado da política de agrocombustíveis e de incentivo à produção de carros flex fuel, declarou: "Os usineiros de cana, que dez anos atrás eram tidos como bandidos do agronegócio, estão virando heróis nacionais e mundiais, porque todo mundo está de olho no álcool” (Para Lula, 20/03/2007). 
No entanto, essa fase de efervescência seria curta. Uma nova tensão se abateu sobre o setor a partir da crise financeira mundial de 2008. Na tentativa de combater os reflexos da crise sobre a economia brasileira, o governo passou a controlar artificialmente o preço da gasolina, mantendo-o abaixo da cotação internacional. Dessa forma, entre 2009 e 2013, houve o aumento de $74 \%$ das vendas de gasolina no país e a redução de $16 \%$ das vendas de etanol. Esse fator, associado à redução das exportações de etanol, à falta de financiamento e investimentos e ao endividamento de algumas usinas, sobretudo daquelas que confiaram na projeção de alta demanda de etanol no futuro, provocou o fechamento de 48 usinas entre as safras de 2007/2008 e 2013/2014 (Shikida, 2013, p. 123; Vencovsky, 2013, p. 52; Neves e Trombin, 2014, p. 46).

Assim, após a crise econômica mundial de 2008, começou-se a ficar evidente a necessidade da adoção de novas estratégias econômicas e produtivas, que, aliás, já estavam sendo praticadas desde a década de 1990 por empresas que conseguiam se manter no mercado.

\subsection{A eclosão de uma nova fase: a agroindústria sucroenergética}

\subsubsection{Novas estratégias}

A transição entre um período onde a economia era fortemente regulamentada pelo Estado para outro, onde o livre mercado passou a ditar as regras das relações transacionais econômicas, foi enfrentada pelo complexo sucroalcooleiro por meio da sua reestruturação produtiva e fortemente pautada na incorporação de novas tecnologias, na diversificação de produtos e em modernas formas de administração.

Apesar da tradição familiar ter se mantido no setor, a empresa familiar, de atuação regional, mudou. Inicialmente, alguns usineiros de áreas tradicionais de cana-de-açúcar procederam, em meados da década de 1990, a fusão de usinas, buscando o aproveitamento de benefícios locacionais e administrativos, ao que Vian (2003) denominou de fusão por sinergia. 
Dessa forma, entre 1997 e 1999, dez fusões aconteceram, e no início do século XXI, 16, já com a participação de capital estrangeiro (Revista Exame, 16/02/2002, "Senhor de Engenho"). Iniciou-se, assim, o estabelecimento de alianças com transnacionais, o que levou à internacionalização de segmentos da cadeia produtiva do açúcar. Fusões e aquisições foram se processando na busca da redução de despesas relacionadas ao setor administrativo e produtivo, bem como do uso mais racional da terra.

Esse processo se deu por meio da aplicação de capitais de consórcios de empresários e fundos de investimentos internacionais, com ou sem a sua participação ativa nas operações de produção e comercialização do açúcar e álcool (Schlesinger, 2008, p. 22), o que, após a crise de 2008, foi facilitado, devido à desestruturação da organização do setor e aos seus impactos diretos na gestão e operação das usinas (Vencovsky, 2013, p. 52). Foi o caso das francesas Louis Dreyfus Commodities (LDC) e Tereos, das americanas Cargill, Bunge e ADM (Archer Daniels Midland); da inglesa British Petroleum (BP), da anglo-holandesa Shell; da chinesa Noble; e da japonesa Sojitz (Quadro 6).

Quadro 6. Principais empresas internacionais atuantes no setor sucroenergético brasileiro (2015).

\begin{tabular}{|c|c|c|}
\hline $\begin{array}{c}\text { Grupo } \\
\text { internacional }\end{array}$ & Participação no setor sucroenergético & Ano \\
\hline \multirow{6}{*}{$\begin{array}{l}\text { Louis Dreyfus } \\
\text { Commodities } \\
\text { (LDC) }\end{array}$} & Aquisição da Usina Cresciumal (SP) ${ }^{1}$ & 2000 \\
\hline & Aquisição da Usina Luciânia, atual Lagoa da Prata (MG) ${ }^{1}$ & 2001 \\
\hline & Aquisição da Usina São Carlos (SP)'1, desativada em 2012 & 2004 \\
\hline & $\begin{array}{l}\text { Aquisição das Usinas Passa Tempo (MS), Maracaju (MS), Esmeralda } \\
\text { (MS), Estivas (RN), Destilaria de Álcool Giasa (RN), do grupo Tavares } \\
\text { de Melo (PE) })^{2}\end{array}$ & 2007 \\
\hline & Inauguração da Usina Rio Brilhante (MS) & 2008 \\
\hline & $\begin{array}{l}\text { Aquisição de } 60 \% \text { da Santa Elisa Vale, controladora das Usinas San- } \\
\text { ta Elisa, Vale do Rosário, Morro Agudo, Continental e Jardest. Nasce } \\
\text { a LDC-SEV }\end{array}$ & 2009 \\
\hline
\end{tabular}


continuação da p. 198

\begin{tabular}{|c|c|c|}
\hline \multirow{2}{*}{$\begin{array}{l}\text { Louis Dreyfus } \\
\text { Commodities } \\
\text { (LDC) }\end{array}$} & Alteração do nome LDC-SEV para BIOSEV & 2012 \\
\hline & A Usina Jardest entra em hibernação ${ }^{2}$ & 2014 \\
\hline \multirow{3}{*}{ Cargill } & $\begin{array}{l}\text { Formação de joint venture com Crystalsev (Grupo Santaelisa Vale) para } \\
\text { controle de dois terminais de exportação de açúcar na Baixada Santis- } \\
\text { ta. Desde os anos de 1990, a Crystalsev fornecia à Cargill açúcar para } \\
\text { exportação }\end{array}$ & 2001 \\
\hline & $\begin{array}{l}\text { Aquisição de } 63 \% \text { da Usina Central Energética Vale do Sapucaí (SP), do } \\
\text { Grupo Maubisa Agrícola Ltda., do empresário Maurílio Biagi Filho }{ }^{10} \text {. Os } \\
\text { outros } 37 \% \text { são da Canagrill }\end{array}$ & 2006 \\
\hline & $\begin{array}{l}\text { Formação de joint venture com o Grupo da Usina São João (de Her- } \\
\text { mínio Ometto) e criação da SJC Bionergia, que controla as Usinas São } \\
\text { Francisco e Rio Dourado, em Goiás }{ }^{3}\end{array}$ & 2011 \\
\hline \multirow{4}{*}{ Tereos } & $\begin{array}{l}\text { Aquisição da Açúcar Guarani, pertencente primeiramente ao grupo Ga- } \\
\text { fisa e depois à francesa Béghin-Say4 }\end{array}$ & 2002 \\
\hline & $\begin{array}{l}\text { Aquisição da Usina São José (SP), do grupo Andrade (SP) } \\
\text { Aquisição da Usina Tanabi (SP), do Grupo Petribu (PE) }\end{array}$ & 2006 \\
\hline & Aquisição da Usina Andrade (SP), do Grupo Andrade (SP) & 2007 \\
\hline & $\begin{array}{l}\text { Compra de 50\% de participação da Usina Vertente (SP), do Grupo Moe- } \\
\text { ma }^{6} \text {. Os outros } 50 \% \text { pertencem ao Grupo Húmus Agroterra } \\
\text { Aquisição da Usina Mandu (SP), de fazendeiros de Orlândia, Barretos } \\
\text { e Guaíra }\end{array}$ & 2010 \\
\hline \multirow{5}{*}{ Bunge } & $\begin{array}{l}\text { Aquisição da Usina Santa Juliana (MG), instalada em 2004, do Grupo } \\
\text { Tenório, de } \text { Alagoas }^{8}\end{array}$ & 2007 \\
\hline & $\begin{array}{l}\text { Aquisição de } 60 \% \text { da Usina Monteverde (MS), do empresário gaúcho } \\
\text { Flávio Wallauer }{ }^{9}\end{array}$ & 2008 \\
\hline & $\begin{array}{l}\text { Aquisição do Grupo Moema Participações. Dentre seus principais acio- } \\
\text { nistas, encontravam-se Maurílio Biagi Filho (SP) e integrantes da Famí- } \\
\text { lia Junqueira Franco (SP) Consequentemente, tornou-se controladora } \\
\text { das Usinas Itapagipe e Frutal, em Minas Gerais; Ouroeste, Guariba e } \\
\text { Moema, em São Paulo }{ }^{10}\end{array}$ & 2010 \\
\hline & $\begin{array}{l}\text { Inauguração da Usina Pedro Afonso (TO), em parceria com a Itachu, } \\
\text { trading japonesa. O etanol produzido por essa usina é qualificado pela } \\
\text { Agência de Proteção Ambiental norte-americana para ser exportado } \\
\text { para os EUA }{ }^{10}\end{array}$ & 2011 \\
\hline & Compra do projeto da Usina Campina Verde (MG), da BP${ }^{16}$ & 2012 \\
\hline
\end{tabular}

continua na p. 200 


\begin{tabular}{|c|c|c|}
\hline $\mathrm{ADM}$ & $\begin{array}{l}\text { Formação de joint venture com o grupo Canaã participações, de Antônio } \\
\text { Cabrera (SP), para a instalação da Usina Limeira do Oeste }(M G)^{12}\end{array}$ & 2007 \\
\hline & Aquisição do total das ações da Usina Limeira do Oeste $(\mathrm{MG})^{13}$ & 2011 \\
\hline \multirow{3}{*}{$\begin{array}{l}\text { British } \\
\text { Petroleum } \\
\quad \text { (BP) }\end{array}$} & $\begin{array}{l}\text { Aquisição de } 50 \% \text { de participação da Usina Tropical (GO), associada- } \\
\text { mente com LDC e Brasil Biodiesel }{ }^{14}\end{array}$ & 2008 \\
\hline & $\begin{array}{l}\text { Aquisição do restante das ações da Usina Tropical (GO), assumindo o } \\
\text { seu controle operacional }{ }^{14} \\
\text { Aquisição da CNAA e, consequentemente, das Usinas Itumbiara (GO) e } \\
\text { Ituiutaba (MG) e do projeto da Usina Campina Verde (MG) }{ }^{15}\end{array}$ & 2011 \\
\hline & Venda do projeto da Usina Campina Verde (MG) para a Bunge ${ }^{16}$ & 2012 \\
\hline \multirow{3}{*}{ Noble } & Aquisição da Usina Noroeste Paulista (SP), do grupo Petribu (PE) ${ }^{17}$ & 2007 \\
\hline & $\begin{array}{l}\text { Aquisição das Usinas Catanduva (SP) e Potirendaba (SP), do grupo Cer- } \\
\text { radinho, da família Fernande }{ }^{18} \\
\text { Início da operação da Usina Meridiano }{ }^{17}\end{array}$ & 2010 \\
\hline & $\begin{array}{l}\text { Formação de joint venture com a COFCO e consórcio de investidores, } \\
\text { denominado Noble Agri, controlada pela estatal chinesa } \mathrm{COFCO}^{19}\end{array}$ & 2014 \\
\hline Shell & Formação de joint venture com o grupo Cosan16, formando a Raízen. & 2011 \\
\hline
\end{tabular}

Fontes: 1 - BIOSEV, [s.d.]; 2 - LOUIS DREYFUS, 2007; 3 - SJC BIONERGIA, [s.d.]; 4 - AÇÚCAR GUARANI, 2007; 5,13,17 - JORNAL CANA, [s.d.]; 6 - AÇÚCAR GUARANI, 2010; 7 - GUARANI, 2010; 8 - GOVERNO DO ESTADO DE MINAS GERAIS, 2010; 9 - BUNGE, 2008; 10 - BUNGE, [s.d.]; 11 - CARGILL AGRÍCOLA, 2006; 12 - ADM, [s.d.]; 14 - BP, [s.d.]; 15 - BP, 2011; 16 - BP BIOCOMBUSTIVEIS, 2012; 18 - NOBLE, 2010; 19 - NOBLEAGRI, [s.d.].

Assim, apesar dos impactos da crise financeira de 2008, importantes empresas continuaram a investir no setor, devido ao alto potencial do Brasil de se tornar o grande produtor e exportador de etanol, considerando-se o contexto da busca mundial por um combustível renovável ambientalmente sustentável. Várias usinas que tinham muitas dificuldades em pagar seus fornecedores de cana-de-açúcar e de honrar seus compromissos financeiros buscaram solução para seus problemas de caixa na venda de seus ativos, em fusões ou na formação de joint ventures com empresas estrangeiras ou grandes grupos nacionais.

Esses grandes grupos passaram a incorporar em suas operações, portanto, a produção de etanol, de açúcar, de cogeração de energia, 
atuando também na comercialização dos produtos e na instalação de infraestruturas de armazenamento e de transporte, como alcoodutos.

A partir da segunda década do século XXI, observa-se um forte processo de desnacionalização do setor. Comparando-se os dados, enquanto em 2006, a participação de grupos estrangeiros era de $3 \%$, em 2012, foi de 33\% (Estrangeiros são a nova geração de usineiros, 2013).

Deve-se ressaltar que na maioria dos casos as empresas internacionais adquirem a planta industrial e não a totalidade das propriedades para o plantio. A matéria-prima é, na maior parte das vezes, proveniente de fornecedores, tendo em vista que a Instrução Normativa $\mathrm{n}^{\mathrm{o}}$ 76/2013, do Incra, baseada no Parecer da Advocacia Geral da União de 2010 e na Lei ${ }^{0} 5 \cdot 709 / 71$, determina que a aquisição e o arrendamento de terras por pessoa natural estrangeira é limitada a 50 módulos de exploração indefinida ${ }^{14}$ (MEI) e a 100 MEI, no caso de pessoa jurídica estrangeira ou de pessoa jurídica brasileira com capital majoritariamente estrangeiro, em área contínua ou descontínua.

Extrapolando esses limites, a aquisição só pode se dar mediante autorização do Congresso Nacional. A IN estabelece ainda que a soma dos imóveis rurais adquiridos por estrangeiros não pode ultrapassar $25 \%$ da área do município, e que o acesso à terra por uma mesma nacionalidade é limitado a 10\% da área do município (Incra, 2013). Portanto, como o MEI varia de 5 a 100 hectares, a extensão máxima de terras que pode ser adquirida por estrangeiros é de 10.000 hectares.

Além da desnacionalização, outro aspecto que chama a atenção é a entrada de grandes empresas nacionais de outros ramos nesse setor. Foi o caso da Odebrecht, empresa originariamente do ramo da construção. Em 2007, a empresa criou a ETH Bioenergia, em sociedade com a japonesa Sojitz, rebatizada em 2013 como Odebrecht Agroindustrial. $\mathrm{Na}$ tentativa de desvincular-se do nome Odebrecht, devido aos proces-

${ }^{14}$ O Módulo de Exploração Indefinida - MEI é uma unidade de medida expressa em hectares, definida para cada imóvel rural inexplorado ou com exploração não definida, em função da Zona Típica de Módulo do município de situação do imóvel. Varia de 5 a 100 ha. As zonas típicas de módulo são regiões delimitadas pelo Incra com características ecológicas e econômicas homogêneas, baseada na divisão microrregional do IBGE, considerando as influências demográficas econômicas de grandes centros urbanos (Souza, 2010, p. 19-20). 
sos da Lava Jato, passou a ser denominada em 2017 como Atvos, atuando na produção e comercialização de etanol, açúcar VHP e geração de energia a partir da biomassa.

Outra empresa que passou a atuar diretamente na produção de etanol foi a Petrobras. Em 2008, foi criada a Petrobras Bicombustível, subsidiária da Petrobras, com o objetivo de produzir etanol e biodiesel de mamona, girassol, soja e dendê. Em 2010, a empresa constituiu parcerias com grupos do setor. Com o grupo Turdos Participações, adquiriu 43,58\% da Bambuí Bionergia (MG); com a Tereos Internacional, controladora da Açúcar Guarani, participa das operações das usinas Severínia, Cruz Alta, São José, Andrade, Vertente, Tanabi e Mandu, todas em São Paulo, passando a ter, em janeiro de 2016, 45,9\% das ações; e com o Grupo São Martinho, adquiriu 49,5\% de participação da Usina Boa Vista, em Goiás.

Contudo, ao final de 2014, após revelada a existência dos desvios de recursos na companhia, vários ativos, dentre eles as participações nos empreendimentos de produção de bioenergia, foram vendidos e as atividades de produção de biocombustíveis encerrada.

\subsubsection{Avanços tecnológicos e diversificação produtiva}

Desde o início do processo de desregulamentação parcial da economia brasileira, o complexo sucroalcooleiro nacional foi impelido a utilizar novas estratégias de mercado, baseadas na diferenciação de produto, na diversificação produtiva e na especialização da produção de açúcar e álcool (Carvalho, 2002, p. 278).

Máquinas e insumos se firmaram na produção agrícola, e a automação e as modernas formas de administração passaram a ditar o tempo e a produtividade nas indústrias. Parcela do setor sucroalcooleiro se modernizou, rápida, mas desigualmente, e empresas e produtores canavieiros que não absorveram tais inovações não conseguiram mais se manter no mercado.

Algumas usinas passaram a realizar investimentos para suprir o mercado com açúcares diferenciados, tais como o açúcar líquido, o líquido invertido, o demerara, o mascavo, o açúcar orgânico e o VHP Very High Polarization. 
O açúcar líquido é um adoçante natural obtido a partir da dissolução do açúcar cristal em água. Possui um brix ${ }^{15}$ que varia em geral entre $65 \%$ a $67 \%$, tendo o mesmo sabor e poder adoçante do açúcar comum. O açúcar líquido invertido é um xarope com alto teor adoçante, cerca de $76 \%$ a $78 \%$ de brix. O açúcar líquido possui maior facilidade de emprego devido à sua uniformidade, à ausência de formação de cristais no processo produtivo, à eliminação da etapa de dissolução e, consequentemente, à redução do consumo de água e energia nas indústrias que o empregam. Tem alta demanda nas indústrias alimentícias, como de refrigerantes, sorvetes, biscoitos, geleias, frutas em calda, em indústrias farmacêuticas ou de outros produtos, como detergentes, tintas e plásticos, onde a sacarose é utilizada nos processos químicos.

Devido à forma líquida, a fabricação desses açúcares provocou também o investimento em novos sistemas logísticos mais adequados ao seu transporte, o qual passou a ser realizado também a granel, em caminhões tanques e bombonas. São exemplos de usinas que investiram na sua produção, ainda na década de 1990, as Usinas da Barra (SP) e Nova América (SP), atual Raízen, e a Usina Guarani (SP), atual Tereos (Vian, 2003, p. 169).

A busca pela diferenciação do açúcar levou também à valorização de açúcares brutos, que eram feitos nos antigos engenhos banguês, como o mascavo, e à produção do açúcar orgânico, que se tornaram atrativos a partir da década de 1980, quando os alimentos sem aditivos químicos e sem refinação foram valorizados, apresentando desde então crescimento de demanda, tanto externa como interna. Assim, diante da conjuntura favorável, desde meados da década de 1990, usinas e produtores familiares brasileiros interessaram-se por este mercado e investiram na produção desses açúcares.

O açúcar mascavo é produzido geralmente de forma artesanal e familiar. Após moagem da cana-de-açúcar, peneiramento, aquecimento e purificação, a massa concentrada, em torno de $90^{\circ}$ a $95^{\circ}$ brix, é encaminhada do tacho de aquecimento a um batedor, onde é cristalizada. Pequenas frações com caroços são peneirados, triturados e podem

${ }_{{ }^{15}}$ Brix $=$ \% de sólidos solúveis contidos na sacarose. 
retornar ao açúcar peneirado previamente. Dependendo da qualidade da cana, podem ser produzidos cerca de 91 a $138 \mathrm{~kg}$ de açúcar mascavo por tonelada de cana-de-açúcar moída (César e Silva, s/data, p. 5). A resolução 12/33 de 1978, da Comissão Nacional de Normas e Padrões para Alimentos (CNNPA) do Ministério da Saúde, definiu que o açúcar mascavo deve conter o mínimo de $90 \%$ de sacarose, elaborado a partir de caldo de cana livre de fermentação, isento de matéria terrosa, de parasitas e de detritos animais ou vegetais.

O açúcar demerara se caracteriza por apresentar cristais envoltos por uma película aderente de melaço de cana. Na sua clarificação emprega-se apenas leite de cal, enquanto para o açúcar cristal branco, são empregados leite de cal e anidrido sulfuroso (Machado, 2012, p. 20). Assim, seus nutrientes são mais preservados do que no processo de produção do açúcar refinado e apresenta um sabor mais intenso. Diferentemente do açúcar mascavo, a produção de açúcar demerara se dá em usinas.

O Açúcar VHP, ou Very High Polarization, é semelhante ao açúcar demerara, mas com menor quantidade de mel e de umidade. É, portanto, um açúcar bruto, ou seja, parcialmente purificado, com tonalidade marrom claro, cujo brix gira em torno de 99,4\%, ou seja, 99,4\% da massa total do açúcar e o,6\%, ou menos, de material de resíduos. Geralmente é o açúcar exportado, utilizado como matéria-prima para a produção de açúcar refinado ou em outros processos industriais nos países compradores. Por possuir teor de sacarose muito maior, possibilita a maior comercialização de sacarose em menor volume a ser transportado, além de estar sujeito a menor contaminação. Estima-se que para cada tonelada de cana-de-açúcar processada, sejam produzidos 120 quilos de açúcar VHP, enquanto o rendimento do açúcar bruto comum é de $138 \mathrm{Kg}$ de açúcar/tonelada de cana.

Em seu último levantamento, em 2017, o IBGE estimou a produção brasileira em 3.259 ton/ano de açúcar mascavo, 139.587 ton/ano de açúcar demerara, 23.311.844 ton/ano de açúcar VHP e 2.398.603 ton/ ano de açúcar refinado (IBGE, 2019).

Além destes, outro açúcar cuja procura tem se intensificado atualmente, sobretudo nos países europeus, Estados Unidos, Canadá e 
Japão, é o açúcar orgânico. Para ser caracterizado como tal, esse açúcar precisa ser produzido sem aditivos químicos, tanto na fase agrícola como na industrial, seguir padrões internacionais e possuir o selo de certificadoras de produtos orgânicos. Isso acabou induzindo o desenvolvimento de outras técnicas de fertilização e de manejo do solo e da cultura canavieira, como a adubação orgânica, o controle biológico de pragas e a erosão dos solos com a utilização de plantio de espécies vegetais. No Brasil, são exemplos de produtores de açúcar orgânico as Usinas São Francisco, em São Paulo, e Jalles Machado, em Goiás.

Além do açúcar, a fabricação de cachaça passou por grandes transformações. Desde que a cana-de-açúcar passou a ser plantada em terras brasileiras e as moendas iniciaram a extração do caldo para a produção de açúcar, a cachaça também começou a fazer parte do rol dos produtos fabricados nos engenhos, primeiramente em alambiques de barro cozido, posteriormente, naqueles feitos de cobre.

Produzida a partir dos resíduos da fabricação da rapadura, inicialmente não tinha teor alcóolico, sendo chamada de rapadura azeda, servindo de alimento para cabras, ovelhas e escravos (Cachaça sem mistério, maio de 2003, p. 76).

No período colonial, a cachaça foi utilizada como moeda de troca para a compra de escravos africanos. Depois, com o aperfeiçoamento das técnicas para a sua produção, a bebida começou a compor a mesa dos senhores de engenho e das demais famílias portuguesas. $\mathrm{O}$ seu sucesso foi tão grande que passou a dividir o mercado com os vinhos portugueses, fazendo com que as autoridades portuguesas proibissem a sua comercialização (Cachaça sem mistério, maio de 2003, p. 76-77).

Atualmente, a cachaça pode ser produzida de forma artesanal ou industrial, o que não implica diferença na qualidade do produto, apenas nos processos produtivos. A cachaça artesanal é produzida em pequenos volumes, em bateladas, em alambiques geralmente de cobre. A industrial é fabricada em colunas de destilação, em grandes quantidades e de forma contínua (FEAM, 2013, p. 9).

Em 2001, o Decreto Federal $n^{0} 4.062$ estabeleceu a denominação cachaça como indicador de origem da aguardente produzida ex- 
clusivamente no Brasil, no sentido de proteger o produto. E em 2005, a Instrução Normativa $n^{0}$ 13, do Mapa, estabeleceu a diferença entre cachaça e aguardente:

Aguardente de cana é a bebida com graduação alcoólica de $38 \%$ vol (trinta e oito por cento em volume) a $54 \%$ vol (cinquenta e quatro por cento em volume) a $20^{\circ} \mathrm{C}$ (vinte graus Celsius), obtida do destilado alcoólico simples de cana-de-açúcar ou pela destilação do mosto fermentado do caldo de cana-de-açúcar, podendo ser adicionada de açúcares até $6 \mathrm{~g} / \mathrm{l}$ (seis gramas por litro), expressos em sacarose. (Brasil, 2005, p. 1)

[...]

Cachaça é a denominação típica e exclusiva da Aguardente de Cana produzida no Brasil, com graduação alcoólica de 38 \% vol (trinta e oito por cento em volume) a $48 \%$ vol (quarenta e oito por cento em volume) a $20^{\circ} \mathrm{C}$ (vinte graus Celsius), obtida pela destilação do mosto fermentado do caldo de cana-de-açúcar com características sensoriais peculiares, podendo ser adicionada de açúcares até $6 \mathrm{~g} / \mathrm{l}$ (seis gramas por litro), expressos em sacarose. (Brasil, 2005, p. 1)

O Instituto Nacional de Propriedade Industrial (Inpi) é o responsável por garantir a procedência geográfica da cachaça, o que pode agregar ainda maior valor na comercialização do produto. No entanto, até 2019, apenas três regiões possuíam autorização do Inpi para vender a cachaça com indicação de procedência: Parati, no Rio de Janeiro; Salinas, em Minas Gerais; e Abaíra, na Chapada Diamantina, Bahia (Sebrae, [s.d.]).

No Brasil, estima-se que existam 40 mil produtores de cachaça, sendo 70\% industrial e 30\% de alambique (FEAM, 2013, p. 10), tendo sido produzidos, no ano de 2017, 970.538 mil litros (IBGE, 2019). De acordo com o último censo agropecuário (2006), os cinco estados que mais produziram cachaça foram São Paulo, Minas Gerais, Bahia, Rio Grande do Sul e Maranhão.

Há vários tipos de cachaça, desde as mais acessíveis economicamente, produzidas em grandes destilarias, até aquelas mais luxuosas, 
que seguem o chamado segmento premium, no qual as destilarias investem tanto na qualidade como na apresentação da embalagem, produzindo em pequena escala e com alta qualidade de produto (Eu bebo, sim, 05/02/2016).

Nesse sentido, a Resolução $n^{0}$ 13/2005 do Mapa distinguiu da seguinte forma os diferentes tipos de cachaça:

- Cachaça Premium - contém 100\% de cachaça envelhecida por pelo menos um ano em barris de no máximo 700 litros;

- Cachaça Extra-premium - contém 100\% de cachaça envelhecida por pelo menos três anos em barris de no máximo 700 litros;

- Cachaça Envelhecida - contém no mínimo 50\% de cachaça envelhecida por pelo menos um ano em barris de no máximo 700 litros.

Verifica-se, portanto, que um dos efeitos da desregulamentação do setor canavieiro e da redução da rentabilidade da comercialização de açúcar e de álcool, sobretudo na década de 1990, foi o surgimento de novos produtos derivados da cana-de-açúcar, ou seja, da diversidade produtiva.

A diversificação produtiva nas usinas se deu, portanto, pela expansão do número de produtos que poderia ser fabricado a partir do açúcar e que poderiam ter alto valor agregado. Investiu-se na diversidade de tipos de refino, em qualidades, marcas e embalagens que traduzissem essa variabilidade, como foi o caso do açúcar demerara, do açúcar VHP e do açúcar líquido (Carvalho, 2002, p. 278). Nas destilarias e mesmo em alambiques, na fabricação de cachaças mais refinadas, tipo exportação. Concomitantemente, as usinas maiores passaram a vislumbrar outras possibilidades, como o uso mais intensivo do bagaço da cana na produção de energia térmica e elétrica.

O bagaço é o subproduto fibroso da cana-de-açúcar

decorrente do esmagamento da matéria-prima, nas moendas de usinas e destilarias. Constitui-se, regra geral, de 46 a 52\% de umidade, 43 a 52\% de fibras, partículas de terra, e resíduos de caldo com 2 a $6 \%$ de sólidos solúveis (Ripoli et al., 2009, p. 18). 
O bagaço é responsável por $25 \%$ a $30 \%$ em peso da cana moída, portanto, uma tonelada de cana processada produz em torno de 250 a $280 \mathrm{~kg}$ de bagaço e $155 \mathrm{~kg}$ de palhas e pontas (Corrêa Neto, 2001, p. 47). Devido à grande quantidade de bagaço produzido por cada tonelada de cana processada, desde a implantação das primeiras usinas sucroalcooleiras ele foi utilizado para a produção de energia, a princípio para o autoconsumo industrial (Brasil, 2015, p. 362).

Apenas a partir do início do século XXI é que a cogeração baseada em bagaço de cana-de-açúcar foi impulsionada, quando uma grave crise energética afetou o país e o setor percebeu as vantagens econômicas que poderiam ocorrer propiciadas pela venda dos excedentes da energia produzida pelas usinas sucroalcooleiras. Esse fato, associado à valorização das economias de baixo carbono e à modernização dos equipamentos e dos processos industriais de transformação de bagaço de cana em energia elétrica, possibilitaram a maior atuação no setor, assim como a transformação das fábricas de açúcar e etanol em também grandes fornecedoras de energia elétrica para o SIN - Sistema Interligado Nacional (Dantas, 2009, p. 39; Vencovsky, 2013, p. 57).

Os principais fatores que desencadearam o interesse do setor sucroalcooleiro nesse filão do mercado foram, sobretudo:

1. Reestruturação do setor elétrico brasileiro;

2. novo marco regulatório, principalmente a partir de 2004, que possibilitou a realização de contratos de longo prazo para a venda de energia elétrica;

3. novas unidades greenfield, que já incorporaram nos projetos e planos de negócios das usinas a geração de energia elétrica;

4. maior escala de produção, possibilitando melhores contratos para a comercialização de energia. (Vencovsky, 2013, p. 57)

Dessa forma, a maior parte das usinas e destilarias atualmente apresenta em sua planta industrial uma central termelétrica cogeradora. A Aneel, por meio da Resolução Normativa ${ }^{0}$ 235/2006, define a cogeração como "processo operado numa instalação específica para fins da produção combinada das utilidades calor e energia mecânica, esta geralmente convertida total ou parcialmente em energia elétrica, 
a partir da energia disponibilizada por uma fonte primária" (Agência Nacional De Energia Elétrica, 2006, Art. $3^{0}$ ).

De acordo com a Empresa de Pesquisas Energéticas - EPE, no último balanço energético publicado, referente ao ano de 2017, 59,5\% da produção de energia brasileira foram baseados em fontes não renováveis. Em relação às energias renováveis (Figura 12), 16,5\% foi oriunda de derivados da cana-de-açúcar, sendo $71,8 \%$ de bagaço e $28,2 \%$ de etanol (Brasil, 2019, p. 17).

De fato, a geração de energia por biomassa se tornou um excelente filão desde 2014, quando a seca e a consequente redução da geração de energia hidroelétrica fizeram o preço da energia elétrica no mercado livre atingir o teto estabelecido pela Aneel de $\mathrm{R} \$ 822,83$ por megawatt-hora (MWh). Além disso, a mudança nos leilões de energia por parte do governo federal, que passou a adotar preços diferentes de acordo com as fontes de geração, estimulou ainda mais a cogeração no setor sucroalcooleiro, que passava por forte crise devido aos baixos preços do açúcar e do etanol. Nessa época, a termoeletricidade, seja baseada em gás, em biomassa ou no carvão, teve preços de referência de R 209 por MWh, enquanto as fontes solar e eólica tiveram R \$ 137 por MWh (Unica, [s.d.]).

Figura 12. Produção de energia no Brasil, 2017.

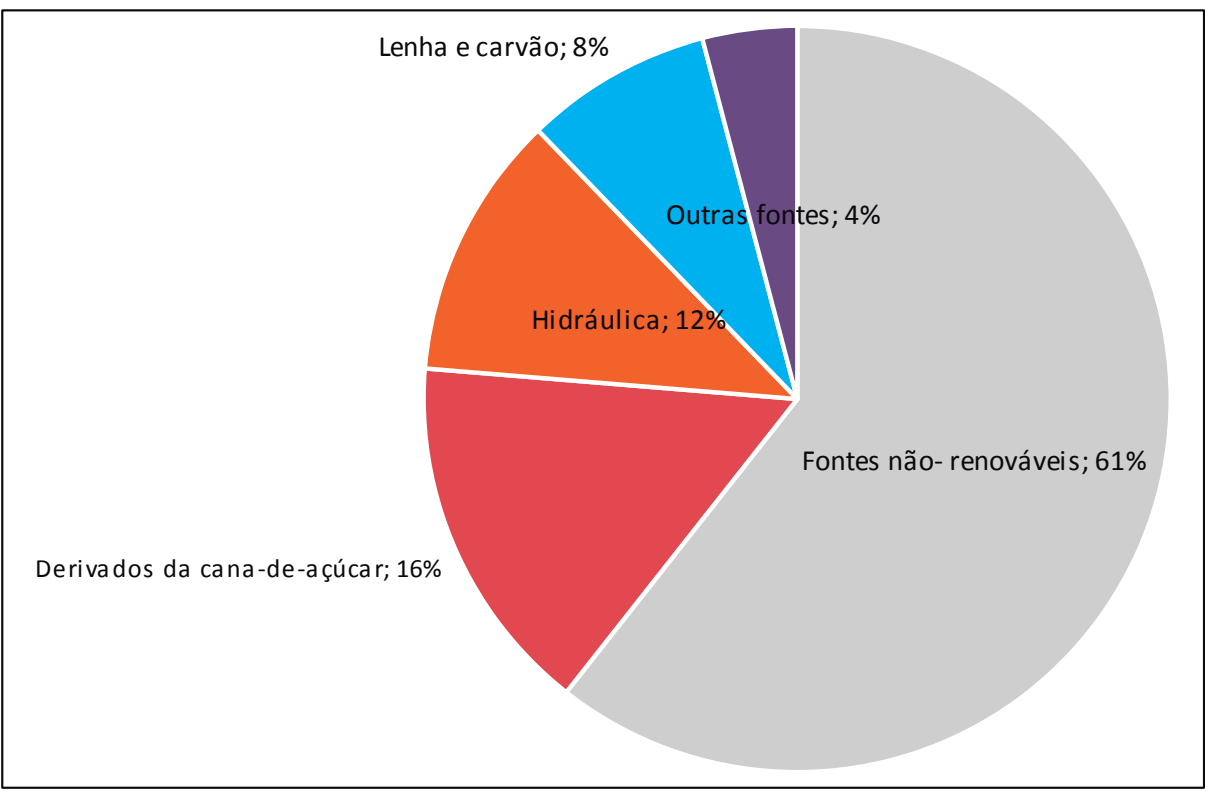

Fonte: EPE, 2019, p. 23. Org.: dos autores, 2019. 
Com uma capacidade instalada de geração de energia elétrica a partir do bagaço de cana-de-açúcar, em 2015, de 10.531.820 KW, ou seja, de $7,11 \%$ de toda a matriz energética do país (Agência Nacional De Energia Elétrica, 2015), a produção de energia passou a ser tão importante nas usinas que o setor até então conhecido como sucroalcooleiro passou a ser denominado de sucroenergético, englobando a produção dos açúcares, de etanol e de energia baseada no bagaço de cana-de-açúcar.

Por haver uma grande quantidade de biomassa disponível nas usinas e na plantação canavieira, outros usos foram sendo pesquisados para sua aplicação, dentre eles a produção de etanol a partir de tecnologias denominadas de segunda geração.

O etanol de segunda geração pode ser produzido a partir da biomassa do bagaço e da palha da cana-de-açúcar, ou de qualquer outra biocelulose, diferentemente do etanol de primeira geração, que tem como matéria-prima o caldo da cana-de-açúcar. No caso do uso da palha da cana-de-açúcar, a sua colheita no campo é realizada por enfardadeiras (Figura 13), máquinas que colhem a palha mais superficial que fica disposta no solo, após a colheita mecanizada, e a enfardam em blocos de cerca de $500 \mathrm{~kg}$. Após esse processo, os fardos são levados até o caminhão, que os transportam até as usinas. Caso seja utilizado também o bagaço, este é associado à palha. Sob altas temperaturas, pressão e vapor, a celulose e a hemicelulose são separadas. Depois, enzimas cortam as moléculas em pedaços menores, e os açúcares são transformados em álcool graças à ação de fermentos, que são destilados e transformados em etanol (Oliveira, 2016).

Em meados de 2010, passou a ser desenvolvida em laboratórios de órgãos de pesquisa, como do Instituto Agronômico de Campinas - IAC, do Centro de Tecnologia Canavieira - CTC e da Rede Interuniversitária para o Desenvolvimento do Setor Sucroenergético - Ridesa, uma variedade resultante de cruzamentos de canas de espécies tradicionais que pode atingir até seis metros de altura, com potencial de produzir até 300 ton/ha. Sua principal característica é a grande quantidade de fibras e de biomassa para ser aproveitada na produção do etanol de $2^{\mathrm{a}}$ geração, diferentemente da cana tradicio- 
nal, cujo principal objetivo é a obtenção da maior quantidade de sacarose. Por ser mais própria para produzir energia elétrica ou etanol de $2^{\text {a }}$ geração, vem sendo chamada de cana energia ou supercana (Super Cana, 10/05/2015).

Figura 13. Enfardadeira de palha da cana-de-açúcar.

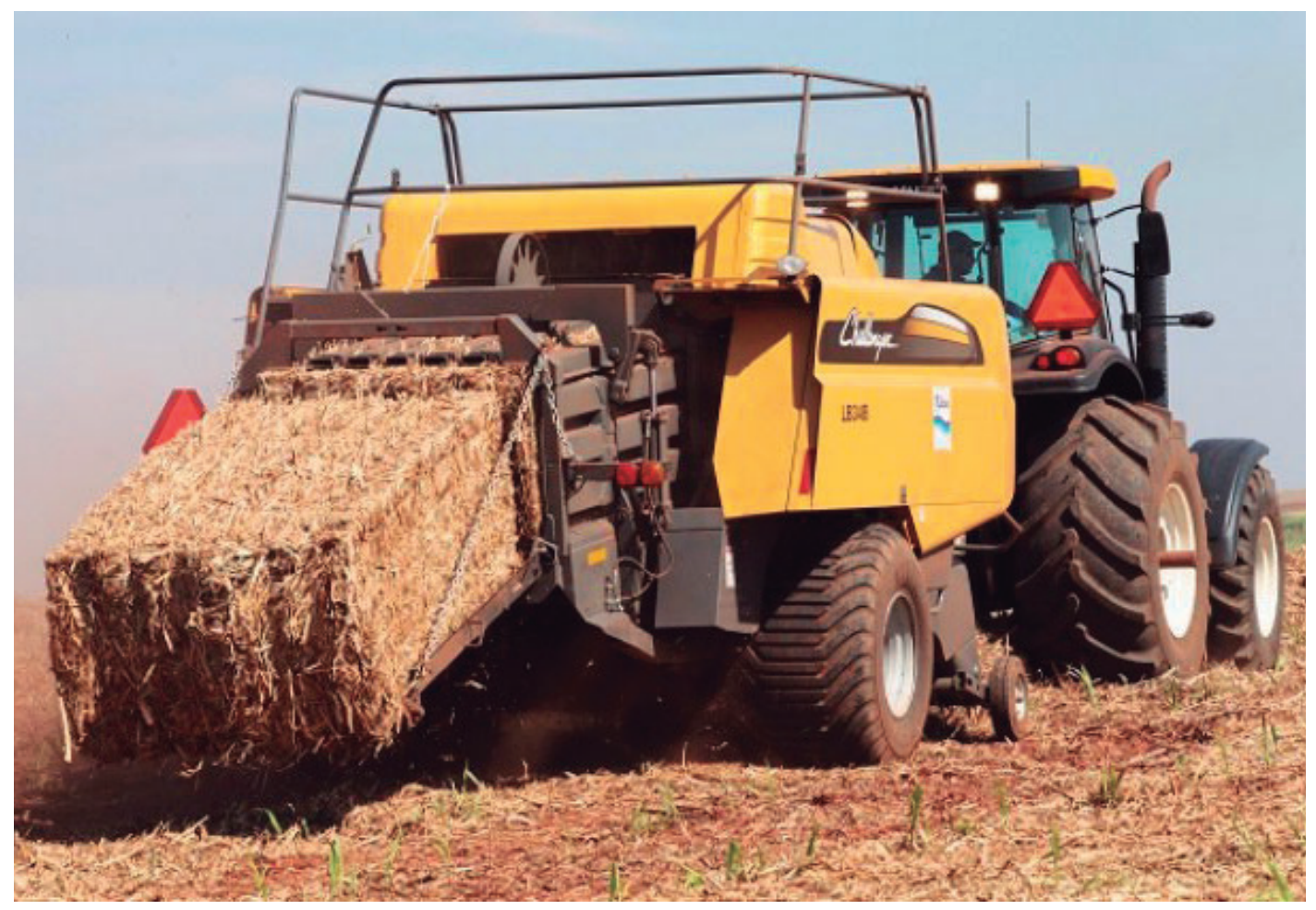

Fonte: CANAONLINE, s/ data. Org. dos Autores, 2016.

Em setembro de 2014, entrou em operação a primeira usina, no Brasil, de etanol de segunda geração, com capacidade instalada de 82 milhões de litros/ano, em São Miguel dos Campos, Alagoas, a Bioflex 1 (Figura 14), pertencente à Granbio, uma holding da Família Gradin, empresa de biotecnologia industrial, e do BNDES, que tem 15\% do capital social (Granbio, [s.d.]a).

Desde maio de 2013, a empresa, em parceria com o IAC e a Ridesa, mantém em Barra de São Miguel, Alagoas, uma estação experimental com 60 hectares com o objetivo principal de desenvolver uma variedade de cana energia, a CanaVertix $®$ (Figura 15), além de outras possíveis fontes de biomassa para futuras unidades industriais (Granbio, [s.d.]b). 
Figura 14. Fachada principal da Usina BioFlex, São Miguel do Campos, Alagoas, janeiro de 2016.

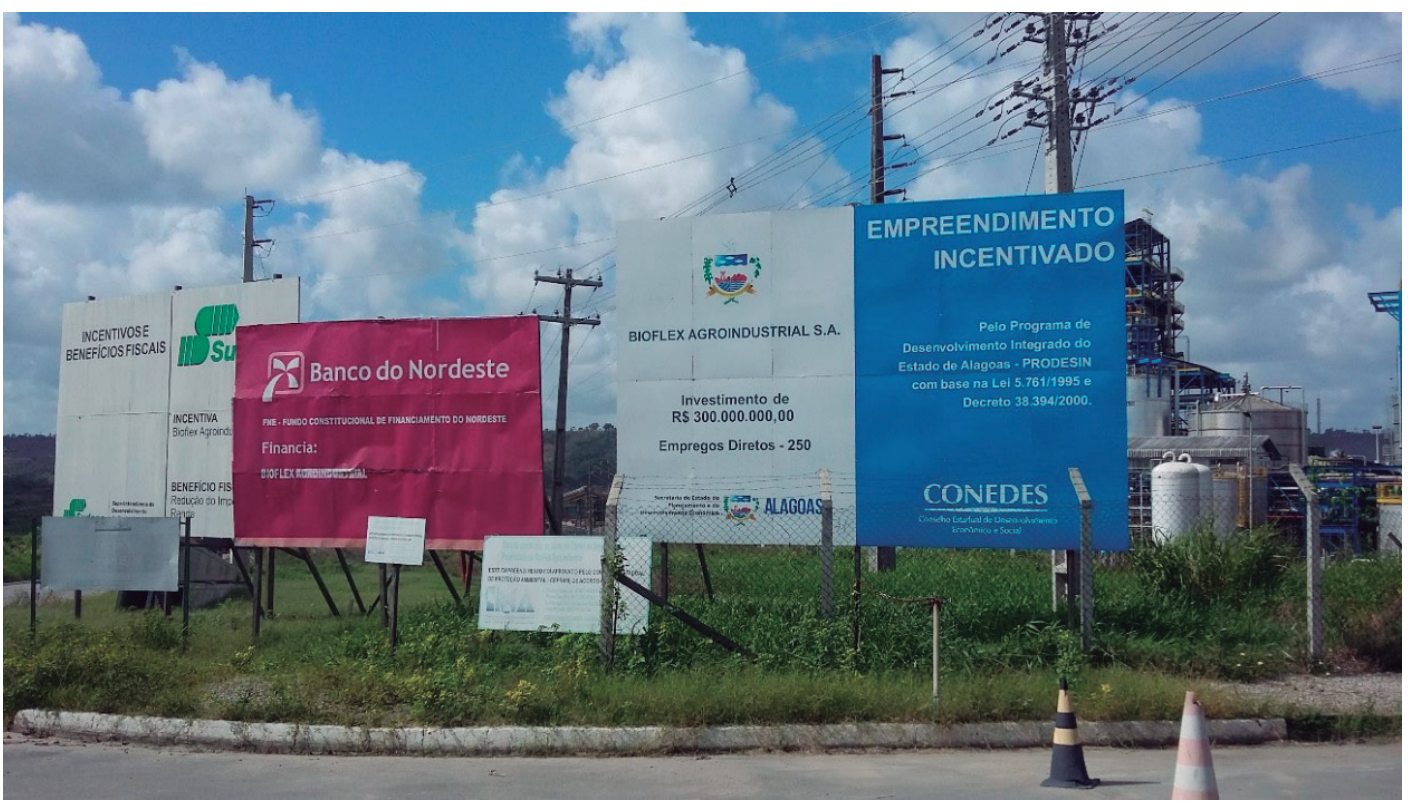

Fonte: acervo dos autores, 2016.

Figura 15. Comparação da altura entre a CanaVertix ${ }^{\circledR}$, à direita, e a RB 92579, à esquerda, tomando-se como base a A.P. de 1,50 cm, na Estação Experimental da GranBio, Barra de São Miguel, AL, janeiro de 2016.

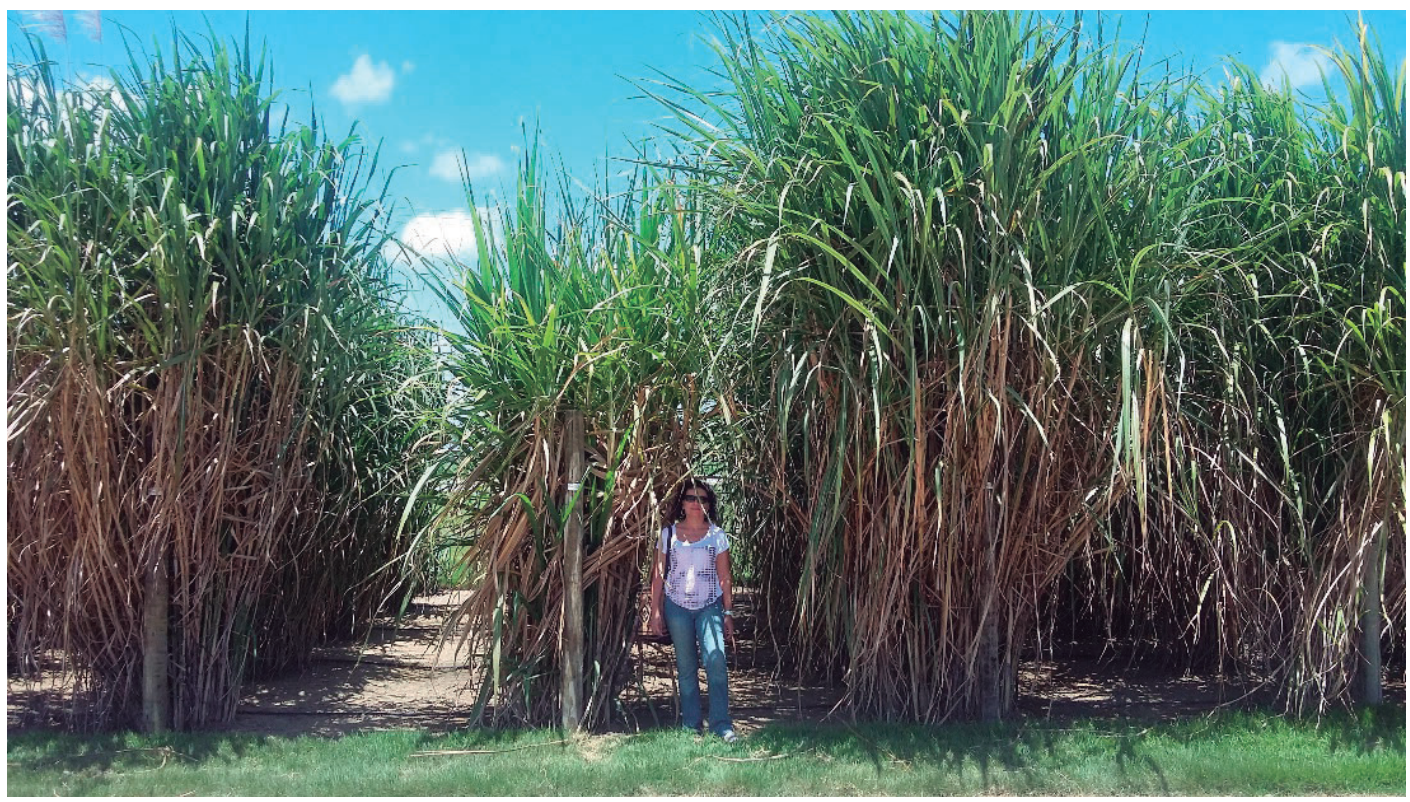

Fonte: acervo dos autores, 2016. 
O desenvolvimento de mudas transgênicas é outra preocupação presente no rol dos interesses científicos e industriais sobre a cana-de-açúcar. Embora as pesquisas tenham começado na década de 2000, a obtenção das primeiras variedades ocorreu apenas em 2011, quando a Empresa Brasileira de Pesquisa Agropecuária - Embrapa anunciou que havia desenvolvido variedades de cana transgênica tolerantes à seca. Em 2017, a Comissão Técnica Nacional de Biossegurança - CTNBio aprovou a primeira variedade transgênica de cana-de-açúcar - a CTC $20 \mathrm{Bt}$, desenvolvida pelo CTC (IBGE, 2017, p. 15-16).

\subsubsection{A cana-de-açúcar na fase sucroenergética}

O plantio e o desenvolvimento da cana-de-açúcar envolvem as etapas de preparo do solo, o plantio de mudas e a prevenção de pragas. Caso seja necessário, devido à fertilidade do solo, procede-se à calagem, para depois se iniciar o plantio da cana. O plantio, atualmente, pode ocorrer de três formas: manual, "onde as etapas de deposição das mudas e a cobertura do sulco ocorrem manualmente”; semimecanizado, "onde a sulcação é efetuada mecanicamente, a deposição das mudas é manual, lançadas de caminhões de carga seca e a cobertura (e adubação) também ocorre mecanicamente"; e o mecanizado, "onde um mesmo conjunto mecanizado efetua a sulcação, a deposição das mudas (em rebolos), a adubação de subsuperfície, a aplicação de agroquímicos de solo e a cobertura do sulco" (Ripoli e Ripoli, 2009, p. 209), que se consolidou, principalmente, a partir dos anos 2000.

Após a maturação, a cana-de-açúcar é colhida, o que envolve a sua limpeza (eliminação de pontas e folhas), corte e carregamento. Atualmente, no Brasil, a colheita é realizada de duas formas: manual, com uso de limpeza do canavial com queima, corte manual (Figura 16) e carregamento mecanizado feito por gruas carregadoras (Figura 17); ou mecanizada, com corte da cana crua, limpeza e carregamento feitos pelas colhedoras.

Após colhida, a cana é transportada até as usinas por caminhões de 15,28 ou 45 toneladas de capacidade de carga, que percorrem uma distância média de $20 \mathrm{~km}$. Na recepção das usinas, a cana é pesada, amostrada e descarregada (Dantas, 2009, p. 37). Na amostragem são 
avaliados parâmetros que determinam a qualidade da cana recebida: o teor de sacarose (Pol) e a porcentagem de sólidos solúveis (brix), os quais determinam o valor do pagamento aos fornecedores de cana.

Figura 16. Colheita manual com uso de fogo como método despalhador. Usina Coruripe, Alagoas, janeiro de 2016.

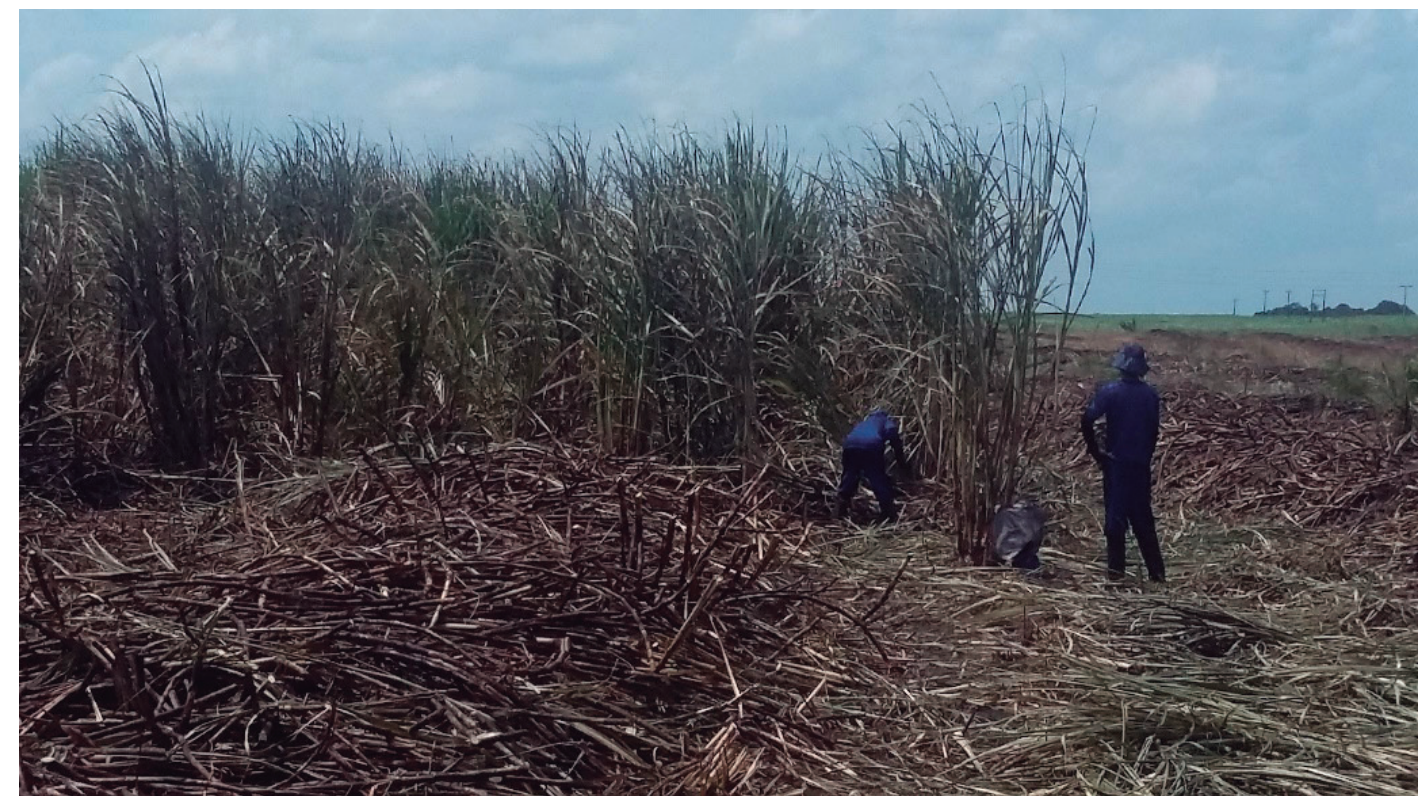

Fonte: acervo dos autores, 2016.

Figura 17. Carregamento de caminhões da cana colhida manualmente, com uso de gruas carregadoras. Usina Coruripe, Alagoas, janeiro de 2016.

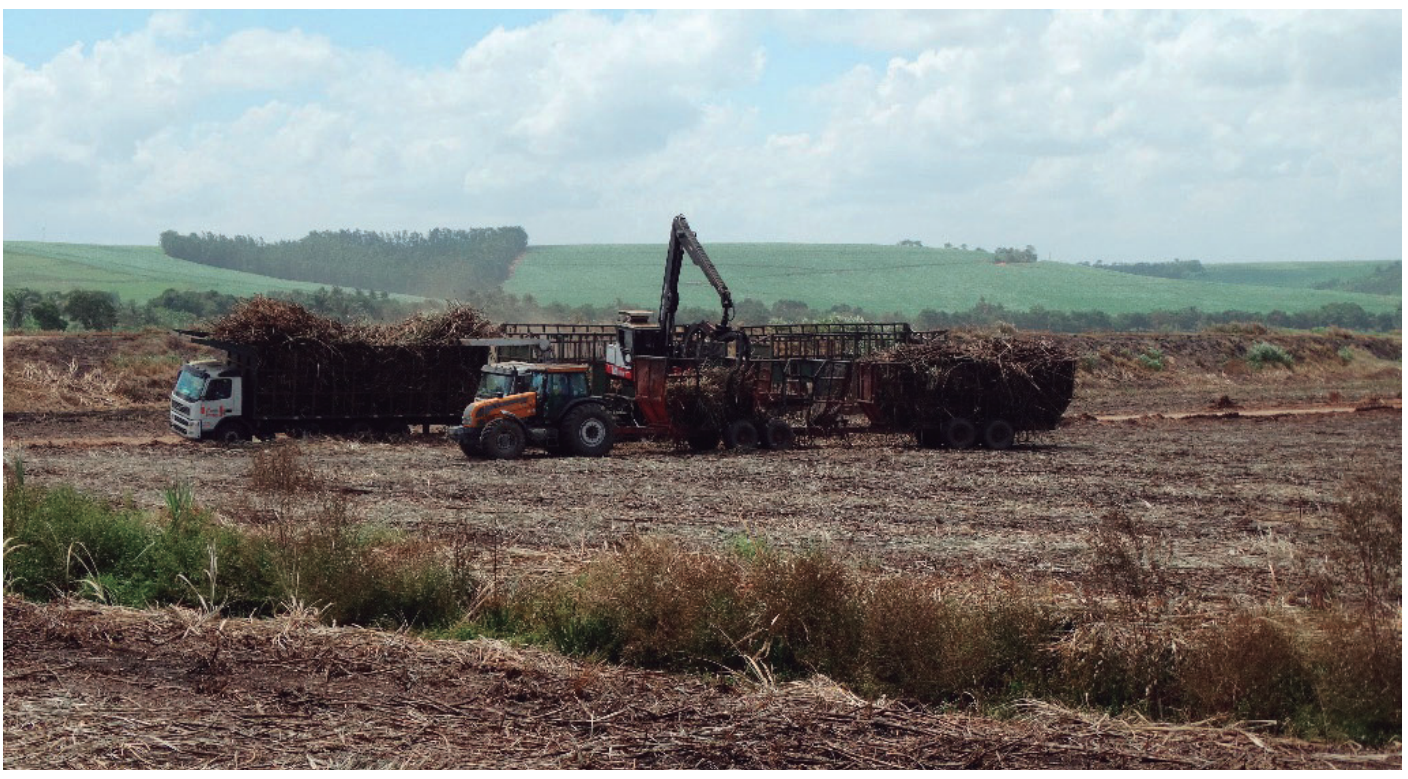

Fonte: acervo dos autores, 2016. 
Uma das grandes mudanças provocadas pelo processo de desregulamentação do setor sucroalcooleiro foi a alteração na forma de pagamento da cana-de-açúcar. Desde a intervenção governamental no setor, na década de 1930, com a criação do IAA (1933) e a instituição do Estatuto da Lavoura Canavieira (1941), o preço da cana-de-açúcar passou a ser determinado pelo Estado, tomando-se como base os custos médios de produção da cana em território nacional e o estabelecimento de uma margem de rentabilidade.

Com a desregulamentação do setor, em 1997, foi criado o Conselho dos Produtores de Cana-de-Açúcar, Açúcar e Álcool do Estado de São Paulo - Consecana, constituído por representantes da Organização dos Plantadores de Cana da Região Centro-Sul do Brasil - Orplana e pela União da Agroindústria do Açúcar e do Álcool do Estado de São Paulo - Unica. Essas organizações foram as responsáveis pela elaboração do novo sistema de pagamento baseado na concentração total de açúcares (sacarose, glicose e frutose) contida em uma tonelada de cana-deaçúcar e recuperáveis no processo industrial, denominada Açúcar Total Recuperável (ATR), cujo valor é atrelado aos preços líquidos do açúcar branco e do etanol anidro e hidratado, destinados aos mercados interno e externo (Sachs, 2007, p. 57/58).

Esse novo sistema de pagamento passou a ser adotado desde a safra de 1998/1999. As usinas geralmente utilizam dois índices de ATR: o índice cana campo, quando a cana-de-açúcar é retirada da propriedade produtora pela usina, e o índice cana esteira, quando o produtor é o responsável pela entrega da matéria-prima na unidade industrial (Sachs, 2007, p. 64). Além disso, o valor do ATR é também utilizado como base para o valor do arrendamento das propriedades pelas usinas.

Após a amostragem da cana, se houver sido utilizada a queima, a cana é lavada com água nas mesas alimentadoras, para a eliminação das impurezas que possam prejudicar o rendimento de produção de caldo, e cortada com facas rotativas. Se for colhida mecanicamente, essa etapa é suprimida. Em sequência, é realizada a extração do caldo por moendas ou difusores, geralmente acionados com o uso de energia térmica, sendo liberado o bagaço (Dantas, 2009, p. 37). 
O caldo da cana é encaminhado para as linhas de produção de açúcar ou álcool. Na produção de açúcar, o caldo passa por um tratamento preliminar, com desareação e peneiramento, para retirada de impurezas mais grossas; sulfitação e caleamento, para o clareamento do caldo; aquecimento, evaporação, cozimento, centrifugação e secagem.

Para a produção do álcool, o caldo, em dornas, sofre o processo de fermentação biológica, onde leveduras catalisam o processo de transformação dos açúcares em álcool. Após rápido esfriamento e centrifugação, o vinho fermentado é destilado, havendo a separação do álcool hidratado da vinhaça. Para a produção do álcool anidro, é adicionado cal virgem $(\mathrm{CaO})$, o qual reage com a água ainda contida no álcool formando hidróxido de cálcio $\left(\mathrm{CaOH}_{2}\right)$, não solúvel em álcool etílico, tornando possível a sua separação do álcool (Gonçalves et al., 2008, p. 251).

Pesquisas sobre outras variedades de cana mais produtivas, com maior teor de sacarose, mais adaptadas a solos pobres e com período de safra mais prolongado, possibilitaram o aumento vertiginoso do rendimento industrial. Em 1584, conseguia-se produzir $1.086 \mathrm{~kg}$ de açúcar por hectare cultivado de cana (Schwartz, 1988, p. 107); em 1781, esse rendimento era de 2.105 kg/ha (Schwartz, 1988, p. 107); em 1933/1934, de 3.204; e em 1970, de 4.232 (Szmrecsányi, 1979, p. 495);. Atualmente, o rendimento industrial é de $11.730 \mathrm{~kg} / \mathrm{hectare}$.

Em termos de produtividade industrial, em 1929/1930, eram produzidos $88 \mathrm{~kg}$ de açúcar por tonelada de cana, mantendo-se esse patamar de aproximadamente $90 \mathrm{~kg} /$ ton até 1975 (Szmrecsányi, 1979, p. 488). Hoje em dia esse valor gira em torno de $138 \mathrm{~kg}$ de açúcar por tonelada de cana (Mapa, 2015).

Segundo Ripoli e Ripoli (2009, p. 203), "a fase produtiva da exploração, entre um plantio e outro, tem a duração de 4 a 6 anos (na região Centro-Sul) ou até mais de 10 anos (no Nordeste)". Após esse período, ou seja, depois de uma média de cinco cortes, há a necessidade de se promover a renovação ou reforma do canavial, para que o rendimento de sacarose não fique muito baixo. Nesse processo, os sistemas radiculares da cana-de-açúcar são arrancados do solo.

Geralmente o terreno é deixado em pousio. Não mais o pousio de seis a oito anos, dos canaviais dos engenhos banguês, quando a área 
era preservada do cultivo, para que a mata secundária crescesse, mas sim de alguns meses, entre a colheita e a implantação de um novo canavial. Desde os anos de 1980, pesquisas agronômicas têm indicado que o plantio de oleaginosas - como a soja, o amendoim e o girassol - pode trazer efeitos benéficos relacionados à fertilidade do solo e ao controle de pragas, aumentando, consequentemente, a produtividade do canavial reformado e o retorno financeiro aos produtores.

\subsection{A geografia canavieira no Brasil atual}

O Brasil é o maior produtor mundial de cana-de-açúcar. Na safra 2018/2019, a área plantada foi superior a 10 milhões de hectares, utilizada predominantemente para a produção de açúcar e etanol. Nessa safra, foram colhidos aproximadamente 674 milhões de toneladas de cana-de-açúcar, tendo sido produzidos 29 milhões de toneladas de açúcar e 33 milhões de $\mathrm{m}^{3}$ de etanol total (Unicadata, 2019; IBGE, 2019, p. 3-19).

Nessa mesma safra, foram exportados 19,91 milhões de toneladas de açúcar, o que manteve o Brasil na posição de principal exportador mundial, seguido pelas exportações tailandesas, de 11,5 milhões de toneladas, e indianas, de 4 milhões de toneladas. Como principais destinos estão Bangladesh, Argélia, Índia, Arábia Saudita e Nigéria (Companhia Nacional de Abastecimento, 2019, p. 10/62; IBGE, 2019, p. 3-19).

Em relação ao etanol, o Brasil é o segundo maior produtor mundial, detendo $28 \%$ do mercado, ao exportar aproximadamente $1,82 \mathrm{mi}$ lhão de $\mathrm{m}^{3}$ de etanol, principalmente para os Estados Unidos, Coreia do Sul, Japão, Holanda e Colômbia. Foi antecedido apenas pelos Estados Unidos, que produziu 60,56 milhões de $\mathrm{m}^{3}$ de etanol de milho (RFA, 2019, p.7; Companhia Nacional De Abastecimento, 2019, p. 63).

A expansão da cana-de-açúcar tem se dado principalmente no Noroeste do Paraná, no Sudeste de Goiás e de Mato Grosso do Sul, no Triângulo Mineiro e Oeste de São Paulo, concentrando-se fortemente no Centro-Sul, com as plantações do Norte-Nordeste abrangendo somente 12,07\% das áreas de plantio (Figura 18), o que se reflete na espacialização da produção açucareira e de etanol (Figura 19). 
Figura 18. Mapa da área colhida (ha) de cana-de-açúcar nos estados brasileiros em 2018.

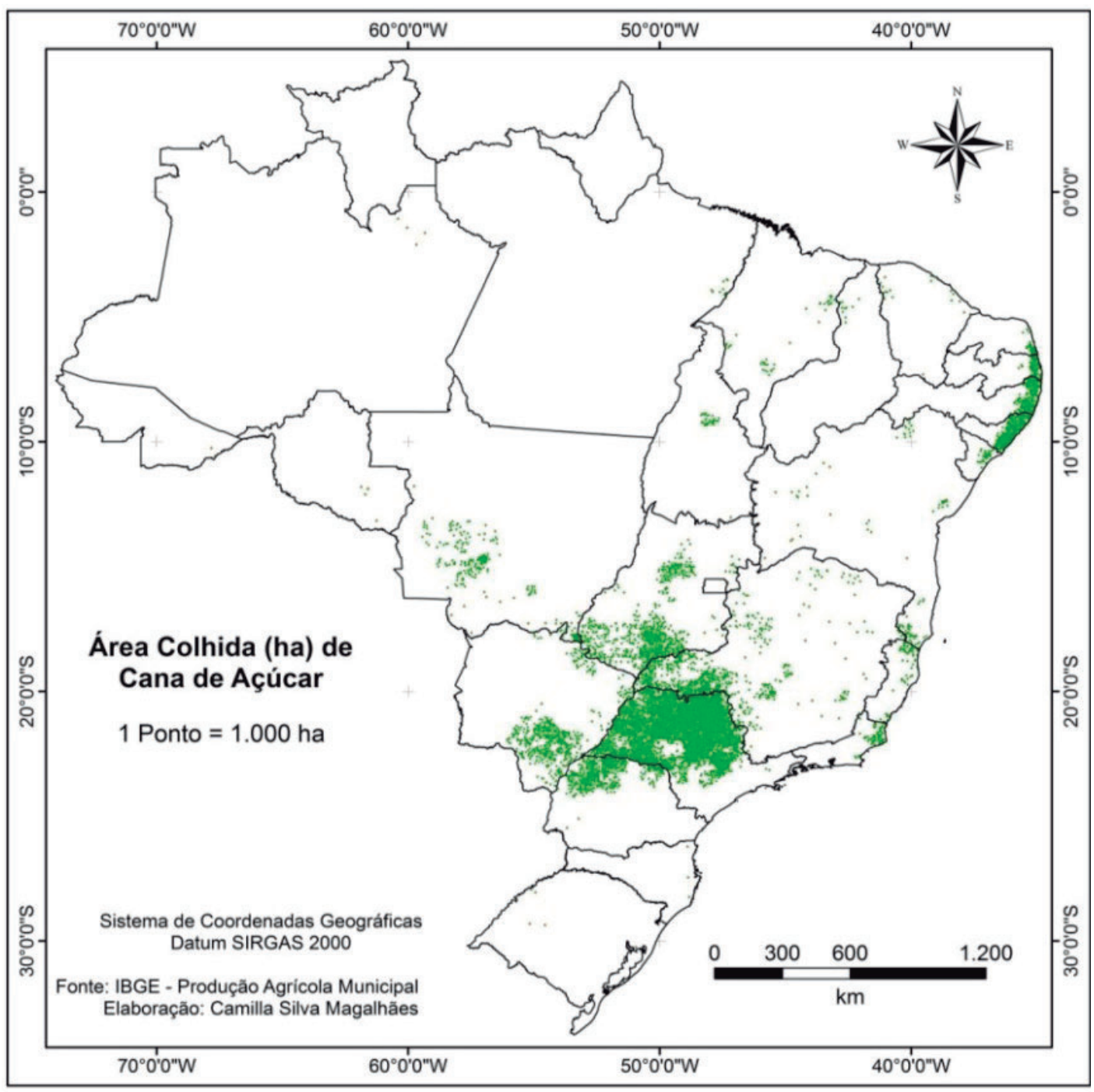

Fonte: dos autores, 2019.

Em relação à geração de energia baseada na biomassa de canade-açúcar, em 2018, foram gerados 35.435 TWh de energia de bagaço de cana, dos quais 21,4 TWh destinados à comercialização no mercado e 14 TWh para consumo próprio da usina (Brasil, 2019, p. 7), concluindo-se que o setor apresenta autossuficiência energética. A capacidade de geração de biomassa da cana teve um aumento superior a 70\% nos últimos cinco anos, chegando a 11,4 GW em outubro de 2018. Em um universo de 367 usinas operantes, aproximadamente 223 unidades comercializam energia (Brasil, 2019, p. 194). 
Ao analisar a configuração da distribuição espacial das fontes energéticas alternativas no Brasil, Egler (2013, p.39) observou que enquanto os geradores eólicos se estendem ao longo do litoral, principalmente nas regiões Nordeste e Sul, os cogeradores de agroenergia baseada em queima de bagaço de cana estão concentrados em São Paulo, Norte do Paraná, Triângulo Mineiro e Mato Grosso do Sul, podendo resultar em uma nova divisão territorial na produção de energia brasileira.

Figura 19. Mapa da moagem de tonelada de cana-de-açúcar e produção de açúcar (ton) e de etanol $\left(\mathrm{m}^{3}\right)$ nos estados brasileiros, 2018.

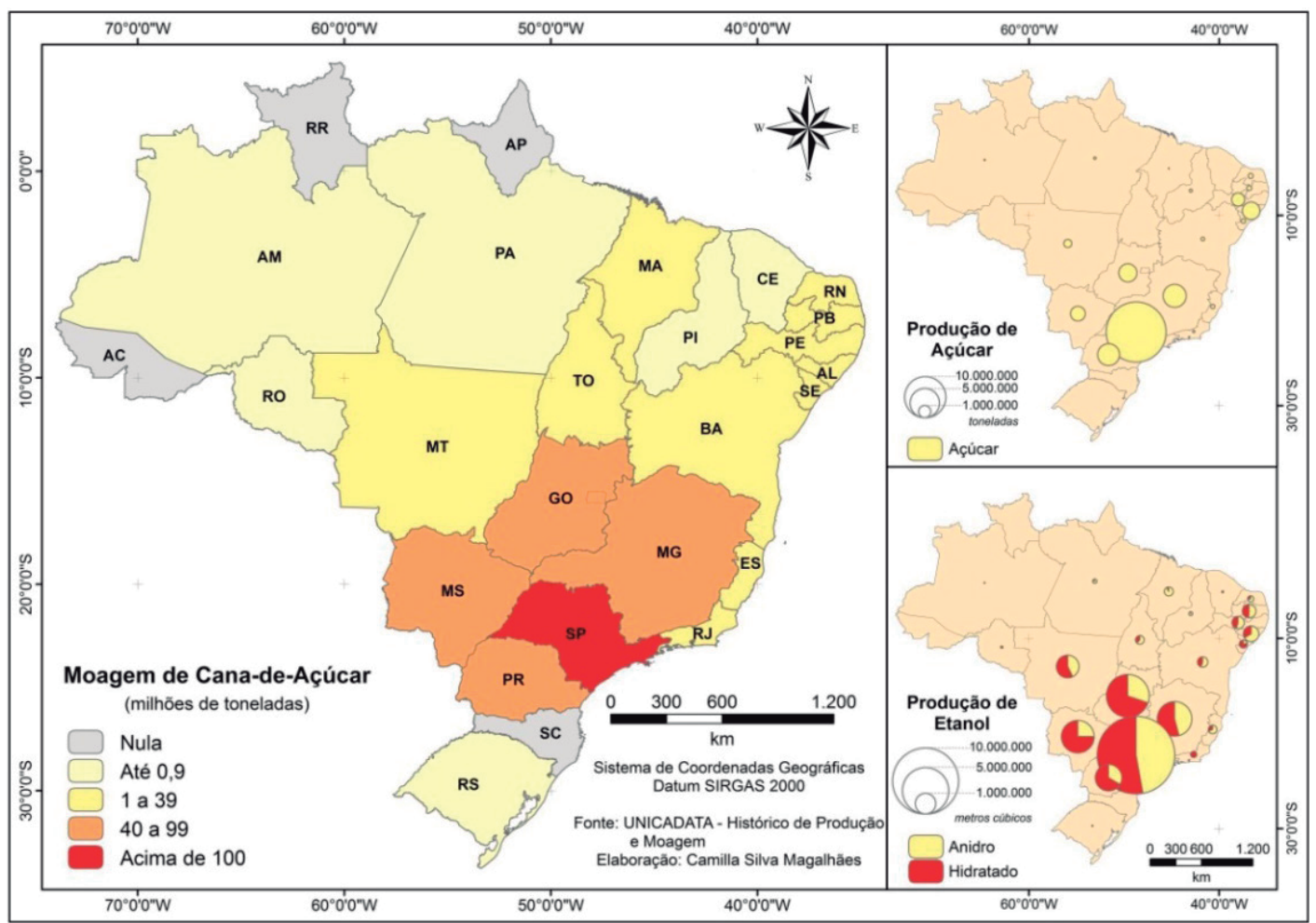

Fonte: dos autores, 2019.

Observa-se, assim, que a cana-de-açúcar manteve o percurso iniciado desde a década de 1970, expandindo-se preferencialmente pelo planalto sedimentar do rio Paraná e seus arredores - Planalto de Maracaju, Planalto de Dourados e Planalto do Rio Verde. Esse trajeto se deu ainda de forma mais vigorosa entre 2006 e 2015, em direção ao Triângulo Mineiro, ao Sul goiano e ao Centro-Sul de Mato Grosso do Sul (IBGE, 2017, p. 31). 
A promulgação de leis que proibiram o uso do fogo como método despalhador e, consequentemente, a promoção da mecanização, fez com que as decisões sobre a localização das novas usinas sucroenergéticas começassem a considerar o fator declividade. Dessa forma, solos naturalmente menos férteis como os Latossolos Vermelhos do Sul de Goiás, mas de relevo plano e com bons índices de pluviosidade, passaram a ser extremamente interessantes para a localização de novos canaviais e usinas (IBGE, 2017, p. 30). Além disso, a concessão de diversos incentivos fiscais por parte do governo fez com que o estado de Goiás se tornasse o terceiro estado com maior área plantada, antecedido apenas por Minas Gerais e São Paulo (Tabela 20).

Tabela 20. Área plantada e colhida, quantidade produzida e rendimento médio da cana-de-açúcar nos estados brasileiros - 2018.

\begin{tabular}{|c|c|c|c|c|}
\hline Estados & Área plantada (ha) & Área colhida (ha) & Quantidade produzida (t) & Rendimento (t/ha) \\
\hline São Paulo & $\begin{array}{r}5.264 .958 \\
\end{array}$ & $\begin{array}{r}4.700 .115 \\
\end{array}$ & $\begin{array}{r}358.438 .815 \\
\end{array}$ & 76.262 \\
\hline Minas Gerais & 1.104 .800 & 917.732 & 70.797 .241 & 77.144 \\
\hline Goiás & 1.036 .440 & 941.439 & 73.448 .244 & 78.017 \\
\hline Mato Grosso do Sul & 670.000 & 670.000 & 49.580 .000 & 74.000 \\
\hline Paraná & 623.521 & 623.521 & 42.068 .520 & 67.469 \\
\hline Alagoas & 375.802 & 320.540 & 17.238 .820 & 53.781 \\
\hline Mato Grosso & 293.290 & 283.780 & 20.433 .828 & 72.006 \\
\hline Pernambuco & 253.756 & 236.624 & 11.957 .196 & 50.532 \\
\hline Paraíba & 133.892 & 99.178 & 5.535 .979 & 55.189 \\
\hline Bahia & 91.000 & 81.000 & 4.680 .000 & 57.778 \\
\hline Rio Grande do Norte & 64.344 & 64.240 & 3.855 .065 & 60.010 \\
\hline Rio de Janeiro & 57.344 & 55.262 & 2.441 .353 & 44.178 \\
\hline Espírito Santo & 54.379 & 45.465 & 2.474 .190 & 54.420 \\
\hline Maranhão & 50.264 & 43.623 & 2.427 .096 & 55.638 \\
\hline Sergipe & 42.260 & 42.260 & 2.048 .765 & 48.480 \\
\hline Tocantins & 39.469 & 38.262 & 3.102 .774 & 79.027 \\
\hline Piauí & 17.280 & 14.594 & 839.544 & 57.527 \\
\hline Rio Grande do Sul & 17.255 & 15.824 & 683.385 & 43.187 \\
\hline Pará & 15.773 & 13.509 & 927.127 & 68.630 \\
\hline Ceará & 12.747 & 10.009 & 571.398 & 57.088 \\
\hline Santa Catarina & 7.139 & 6.780 & 313.015 & 46.167 \\
\hline Amazonas & 4.640 & 4.610 & 263.854 & 57.235 \\
\hline Acre & 504 & 442 & 11.558 & 26.149 \\
\hline Rondônia & 335 & 335 & 15.070 & 44.985 \\
\hline Roraima & 291 & 286 & 3.976 & 13.902 \\
\hline Distrito Federal & 205 & 205 & 17.425 & 85.000 \\
\hline Amapá & 140 & 135 & 4.480 & 33.185 \\
\hline TOTAL & 10.231 .828 & 9.229.770 & 674.178.718 & \\
\hline
\end{tabular}

Fonte: IBGE, 2019, p. 3-19/20. Org.: dos autores, 2019.

De acordo com os dados da Conab (2019, p. 16), Goiás é o segundo estado brasileiro com maior área de mudas plantadas e colhidas na safra de 2018/2019, sendo superado apenas por São Paulo. Contudo as 
áreas para a expansão de cana-de-açúcar no entorno das usinas estão a cada safra se tornando mais limitadas, o que provavelmente levará à estabilização desse tipo de uso.

\subsection{Impactos socioambientais e a sustentabilidade da sucroenergia}

\subsubsection{Entra em cena o meio ambiente}

Durante os quase cinco séculos de cultivo de cana-de-açúcar no Brasil, vários impactos socioambientais foram provocados, descritos nos vários capítulos. Diferentemente do que ocorrera anteriormente, no entanto, depois dos anos de 1970, esses impactos paulatinamente passaram a ser cada vez mais realçados, culminando em regulamentações, não mais relacionadas ao sistema de preços ou a cotas produtivas, mas sim às questões ambientais envolvidas na cadeia produtiva da agroindústria canavieira.

Sob o aspecto político ambiental, a preocupação com as questões socioambientais se materializou em políticas públicas voltadas para o setor sucroalcooleiro, o que definiu, por sua vez, os instrumentos de intervenção do Estado na gestão ambiental e, por conseguinte, territorial.

Desde 1986, o Conselho Nacional de Meio Ambiente (Conama) determinou por meio da Resolução $\mathrm{n}^{0}$ 1/1986 a necessidade da apresentação de Estudos de Impacto Ambiental (EIA) e dos respectivos Relatórios de Impacto Ambiental (Rima) para a obtenção de licença ambiental de atividades potencialmente poluidoras nos órgãos ambientais. Na listagem exemplificativa constam as destilarias de álcool e as usinas de geração de eletricidade, qualquer que seja a fonte de energia primária acima de $10 \mathrm{MW}$ (artigo $2^{\circ}$, incisos XI e XII). Posteriormente, a resolução Conama 237/1997 incluiu nessa lista de atividades sujeitas ao licenciamento ambiental as indústrias de fabricação e refino de açúcar.

A Resolução Conama $n^{0}$ 001/1986, estabeleceu ainda que o EIA deve contemplar o diagnóstico ambiental dos meios físico, biológico e socioeconômico, bem como a análise dos impactos ambientais da implantação e operação das atividades mediante a identificação e a previ- 
são da magnitude e relevância dos impactos. Diante dessas considerações, Elias Neto (2005) formulou a estrutura básica da análise ambiental de EIAs/Rimas da agroindústria canavieira (Figura 20).

Figura 20. Elementos a serem analisados em EIAs de usinas sucroenergéticas

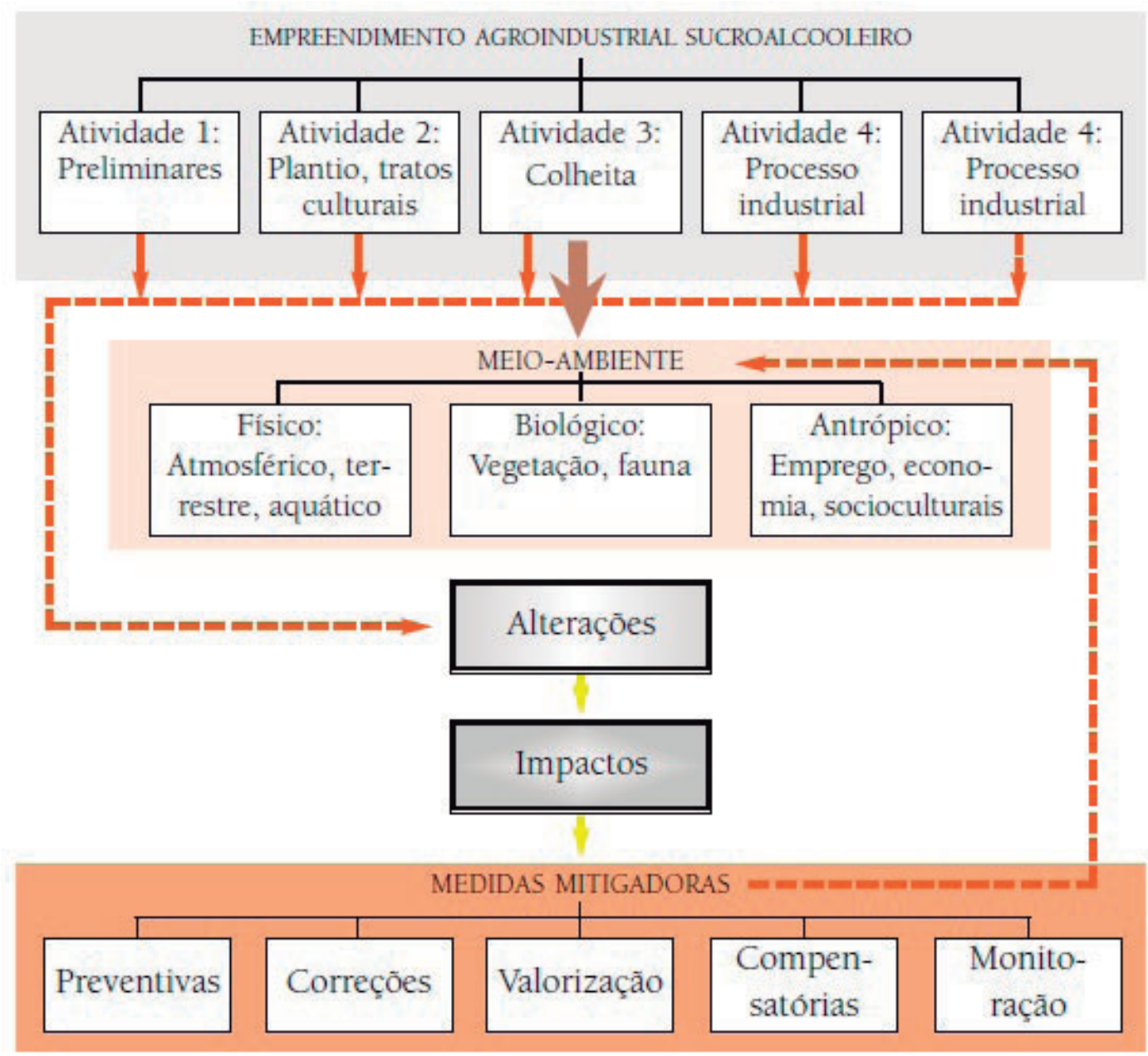

Fonte: Elia Neto, 2005, p. 77.

Embora a avaliação adequada dos impactos ambientais deva abranger os aspectos das áreas agrícola e industrial, a regularização ambiental da planta industrial e das áreas de plantio de cana-de-açúcar em vários estados se dá separadamente. Consequentemente, os impactos decorrentes do processamento industrial da cana-de-açúcar são analisados isoladamente daqueles provenientes pelo seu cultivo.

Desse modo, no processo de licenciamento ambiental da planta industrial, tem-se como foco precipuamente os aspectos referentes aos 
impactos atmosféricos (originados do uso da caldeira e do fogo nos canaviais), aos efluentes líquidos (decorrentes da produção da vinhaça), aos resíduos sólidos (provenientes do bagaço da cana, de cinzas e outros resíduos), ao uso dos recursos hídricos e socioeconômicos.

A inserção de medidas voltadas à economia de energia e matérias-primas, utilizando tecnologias limpas faz com que praticamente todos os impactos ambientais da planta industrial sejam minimizados, permitindo a ênfase, durante o processo de licenciamento prévio, nos efeitos da dinamização econômica e no aumento da empregabilidade derivados da implantação de tais empreendimentos.

Por outro lado, a regularização ambiental das áreas de cultivo pode ser resultante de processo simplificado, como no caso de Minas Gerais, ou não passíveis de licenciamento ambiental, como são as atividades agrícolas no estado de São Paulo. Dessa forma, não são identificados e analisados os impactos socioambientais potenciais e efetivos da atividade, verificando-se apenas a apresentação da escritura, com a averbação da reserva legal, e de outros documentos, como o certificado de outorga para uso dos recursos hídricos na propriedade e a regularização das Áreas de Preservação Permanente, por meio da efetivação do Cadastro Ambiental Rural (CAR).

Em 2009, outro instrumento de planejamento ambiental com foco no setor canavieiro foi regulamentado - o Zoneamento Agroecológico da Cana-de-Açúcar (ZAEcana), estabelecido pelo Decreto Federal $\mathrm{n}^{\mathrm{o}}$ 6961/2009, com o objetivo de "fornecer subsídios técnicos para formulação de políticas públicas visando o ordenamento da expansão e a produção sustentável de cana-de-açúcar no território brasileiro.” (Embrapa, 2009, p. 8).

Por meio do processamento digital, foram elaborados os mapas de zoneamento da cana-de-açúcar, em escala 1:250.ooo, para o território brasileiro, e 21 de suas unidades federativas, excluindo-se as áreas consideradas a priori como de restrição ambiental: áreas pertencentes aos biomas do Pantanal, Amazônia e Bacia do Alto Paraguai; áreas com cobertura nativa e de proteção ambiental; terras indígenas; dunas e mangues; escarpas e afloramentos rochosos; áreas com declividades superiores a $12 \%$, considerando-se o limite para a mecanização das cul- 
turas; áreas de reflorestamento, urbanas e de mineração; e as áreas da região Centro-Sul onde a cana-de-açúcar já estava cultivada na safra 2007/2008. Foram consideradas como áreas aptas para a expansão da cana-de-açúcar as áreas com agricultura intensiva ou semi-intensiva e as pastagens (Embrapa, 2009, p. 7).

A construção dos mapas de zoneamento da Embrapa (2009) pautou-se na integração dos mapas de uso da terra, na aptidão climática e edáfica (edafoclimática). De acordo com o Zoneamento Agroecológico, o total de terras aptas ao plantio da cana-de-açúcar é de 65 milhões de hectares, e o Centro-Oeste e o Sudeste, as regiões que tem as características edafoclimáticas e de uso da terra mais adequadas paras a expansão canavieira (Figura 21), estando localizadas nos estados de Goiás e Minas Gerais a primeira e a segunda maior área apta à expansão do plantio (Tabela 21).

De acordo com os critérios estabelecidos pelo ZAEcana, não há a necessidade de expansão da cana-de-açúcar em áreas com cobertura nativa e utilizadas para a produção de alimentos, tendo em vista que

o país dispõe de cerca de 64,7 milhões de ha de áreas aptas à expansão do cultivo com cana-de-açúcar, sendo que destes 19,3 milhões de ha foram considerados com alto potencial produtivo, 41,2 milhões de ha como médio e 4,3 milhões como de baixo potencial para o cultivo. As áreas aptas à expansão cultivadas com pastagens, em 2002, representam cerca de 37,2 milhões de ha (Embrapa, 2009, p. 7).

Em âmbito estadual, antes do ZAEcana, foi elaborado em São Paulo, em 2008, o Zoneamento Agroambiental do Setor Sucroalcooleiro (ZAA), o qual indica as áreas aptas para o plantio canavieiro e dá a base para a regulação das unidades agroindustriais. Baseado em dados do clima, qualidade do ar, unidades de conservação existentes e indicadas e na existência de fragmentos florestais no estado paulista, apresenta quatro categorias de zonas: áreas adequadas; áreas adequadas com limitação ambiental; áreas adequadas com restrições ambientais; áreas inadequadas. 
Figura 21. Mapa de zoneamento da cana-de-açúcar.

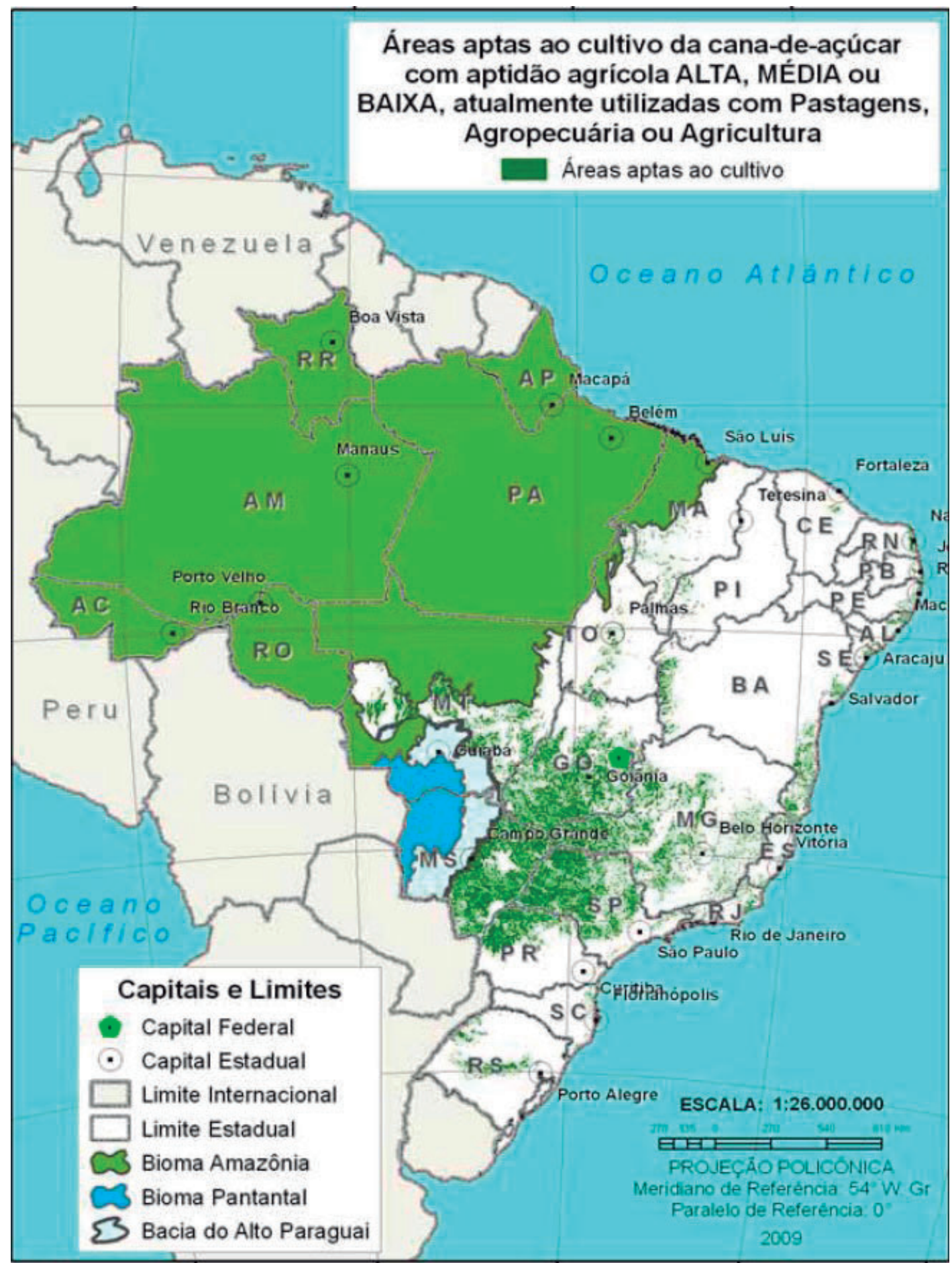

Fonte: EMBRAPA, 2009. Org.: dos autores, 2019. 
Tabela 21. Áreas aptas para a expansão do cultivo da cana-de-açúcar nos estados das regiões Centro-Oeste e Sudeste.

\begin{tabular}{|c|c|c|}
\hline \multirow{3}{*}{ Região } & Estados & $\begin{array}{c}\text { Áreas aptas ao plantio de cana-de-açúcar (ha) } \\
(\mathrm{A}+\mathrm{B}+\mathrm{A})\end{array}$ \\
\hline \multirow{3}{*}{ Centro-Oeste } & Mato Grosso & $6.812 .854,06$ \\
\cline { 2 - 3 } & Mato Grosso do Sul & $10.869 .820,92$ \\
\cline { 2 - 3 } & Goiás & $12.600 .530,81$ \\
\cline { 2 - 3 } & Distrito Federal & $1.223,49$ \\
\hline \multirow{3}{*}{ Sudeste } & Rio de Janeiro & $480.703,49$ \\
\cline { 2 - 3 } & São Paulo & $10.645 .485,23$ \\
\cline { 2 - 3 } & Espírito Santo & $329.654,40$ \\
\cline { 2 - 3 } & Minas Gerais & $11.250 .202,19$ \\
\hline
\end{tabular}

Nota: Classes de Aptidão: A: Alta; M: Média; B: Baixa.

Fonte: EMBRAPA, 2009. Adaptação e organização: dos autores, 2019.

No mapa foi constatado que $26 \%$ das áreas canavieiras do estado de São Paulo estão localizadas em áreas adequadas, $45 \%$ em áreas adequadas com limitações ambientais, 28\% em áreas adequadas com restrições ambientais e apenas 1\% em áreas inadequadas (Figura 22).

O mapa do ZAA serviu de base para a Resolução $n^{0}$ 88/2008 da Secretaria de Meio Ambiente do Estado de São Paulo, que definiu as diretrizes técnicas para o licenciamento ambiental dos empreendimentos do setor sucroalcooleiro, que passou a ser definido de acordo com a localização da unidade industrial no estado.

Em outras unidades federativas, outros instrumentos incorporaram a preocupação com a expansão sustentável do cultivo da cana-de-açúcar, como foi o caso do Zoneamento Ecológico-Econômico. Assim, em Minas Gerais, por exemplo, a primeira versão do ZEE foi elaborada e incorporada à Política Ambiental mineira, em 2006, baseado na combinação dos níveis de potencialidade social com os de vulnerabilidade natural do estado, resultando em um índice ecológico-econômico. Considerando a crescente expansão do setor sucroalcooleiro no estado, foi incluso no ZEE-MG o zoneamento edafoclimático da cana-de-açúcar, sendo que o Triângulo Mineiro se destacou ao apresentar extensas áreas com a melhor aptidão edafoclimática para esse cultivar. 
Figura 22. Zoneamento Agroambiental do Setor Sucroenergético do Estado de São Paulo.

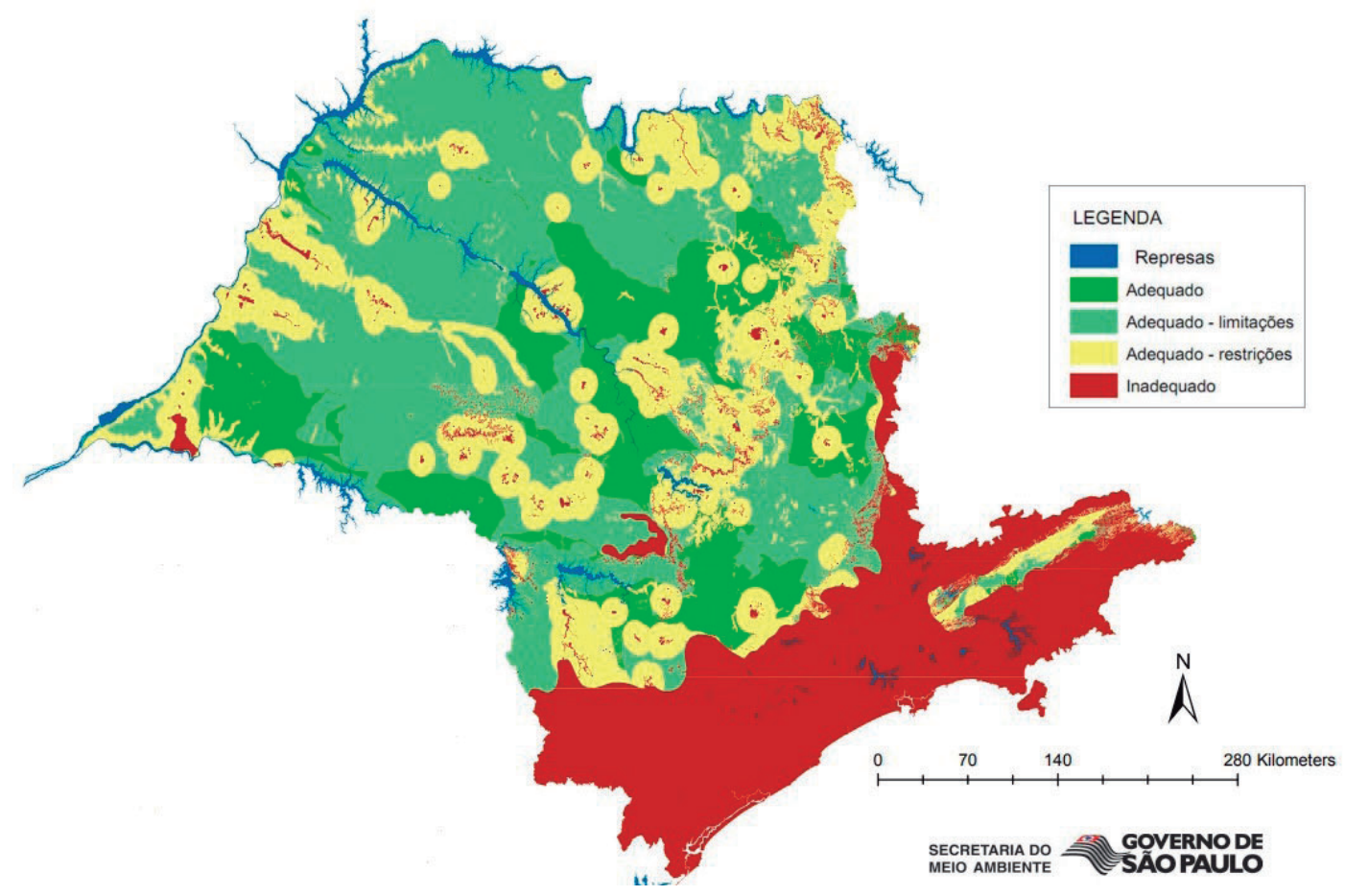

Fonte: SÃO PAULO, 2019. Org.: dos autores, 2019.

Além das regulamentações associadas ao licenciamento ambiental e da criação de instrumentos de ordenamento do território tendo em vista a expansão do setor sucroenergétcio, as atividades relacionadas ao cultivo da cana e à sua industrialização passaram a ser orientadas, a partir dos anos de 1990, como ocorreu com outras atividades produtivas, de modo a incorporar a sustentabilidade socioambiental no plano de seus negócios. Sustentabilidade essa entendida sob uma abordagem tecnocêntrica, em que os recursos naturais são manejados de modo a propiciar o tratamento dos efluentes líquidos e atmosféricos, decorrentes principalmente do reúso da água em circuito fechado, do banimento do fogo e da mecanização na colheita, do uso do bagaço de cana na cogeração de energia térmica e da utilização da vinhaça na fertirrigação dos canaviais. 


\subsubsection{Os impactos socioambientais}

a) Impactos sociais

Um dos impactos apresentados como bastante positivos originados pela instalação e operação das usinas sucroenergéticas, endossados pelos governos municipais e estaduais, é a criação de postos de trabalhos e o aumento da arrecadação de impostos.

Para avaliar essa questão, Barros (2018) analisou os dados de 2000 a 2016 sobre a dinâmica dos empregos formais no setor sucroenergético, indicando que houve a redução do número de empregos formais desde 2007, inicialmente com maior intensidade no setor agrícola, provavelmente devido à mecanização (Tabela 22). Em 2016, na área agrícola, o número de empregos foi praticamente a metade do número de empregos formais de 2008, apesar do aumento das toneladas de cana processada na indústria do Centro-Sul, perdendo a participação desde então no total de empregos formais no setor, quando comparado com os percentuais nas áreas industrial e administrativa.

Tabela 22. Número de trabalhadores formais nas diferentes áreas do setor sucroenergético.

\begin{tabular}{|c|c|c|c|c|c|c|}
\hline Anos & \multicolumn{6}{|c|}{ Áreas } \\
\hline & Industrial & $\%$ & Agrícola & & Administrativo & $\%$ \\
\hline 2000 & 64.454 & 10 & 513.416 & 79,9 & 64.978 & 10,1 \\
\hline 2004 & 88.807 & 9,9 & 726.005 & 80,6 & 85.956 & 9,5 \\
\hline 2008 & 132.923 & 10,4 & 1.023 .814 & 79,8 & 126.521 & 9,9 \\
\hline 2012 & 146.125 & 13,4 & 804.279 & 73,7 & 141.171 & 12,9 \\
\hline 2016 & 126.172 & 15,9 & 555.929 & 69,9 & 112.810 & 14,2 \\
\hline
\end{tabular}

Fonte: Barros, G.S.C., 2018, p. 6. Org.: dos autores, 2018.

Mesmo considerando as áreas industrial e administrativa, percebe-se uma curva descendente entre 2012-2016, provavelmente associada ao fechamento de usinas e ao processo de otimização e automação de algumas empresas (Barros, 2018, p. 7).

Dessa forma, embora as condições de trabalho dos trabalhadores no plantio, cultivo e tratos culturais tenham melhorado com o processo 
de mecanização, a eliminação do uso do fogo no corte da cana-de-açúcar muitas vezes é considerada perversa, tendo em vista o seu impacto na redução da contratação da mão-de-obra volante. Estudo realizado na Usina da Barra (SP) por Vieira (2003, p. 26), por exemplo, constatou que uma colhedora substitui aproximadamente 67 cortadores manuais por hora trabalhada. Cortadores esses que, sem a qualificação profissional necessária, aumentam a massa de desempregados.

No mesmo sentido, o arrendamento e a terceirização, principais mecanismos utilizados pelas usinas para a implantação ou expansão dos canaviais (Cleps, 2009; Assis e Zucarelli, 2007), provoca modificações na disponibilidade de empregos e no fluxo migratório do campo para as cidades. Trabalhadores rurais sem maior qualificação, que antes eram empregados nas fazendas, não conseguem ser absorvidos nas propriedades canavieiras que utilizam grande tecnificação, direcionando-se, muitas vezes, para os subempregos das cidades.

\section{b) Emissões atmosféricas}

No âmbito dos impactos na qualidade do ar provocados pela agroindústria canavieira há três aspectos distintos aos quais podemos nos referir. Os dois primeiros, relacionados aos impactos adversos vinculados à queima da palha da cana no campo e às emissões oriundas da planta industrial. O terceiro, de natureza benéfica, associado ao uso do etanol e aos seus efeitos na atmosfera, quando comparado ao uso da gasolina e de outros combustíveis fósseis.

O uso do fogo para a limpeza do canavial sempre foi prática usual, tendo como objetivo a eliminação da palha e das folhas secas e, consequentemente, a facilitação do corte, o carregamento e o transporte dos colmos da cana. Contudo a falta de controle da queimada faz com que muitas vezes as labaredas atinjam as redes elétricas e a fumaça e a fuligem prejudiquem a visão em rodovias, causando acidentes.

Além disso, a queima da cana libera para a atmosfera monóxido de carbono $(\mathrm{CO})$, dióxido de carbono $\left(\mathrm{CO}_{2}\right)$, metano $\left(\mathrm{CH}_{4}\right)$, óxido nitroso $\left(\mathrm{N}_{2}\right)$ e óxido de nitrogênio (NOX), que podem causar problemas à saúde do trabalhador e da população residente no entorno dos canaviais, além de serem responsáveis pelo efeito estufa (Coelho et al., 
2010, p. 244; Cerri et al., 2010, p. 201). Causam também mudanças na composição química, física e biológica do solo, afetando a ciclagem de nutrientes, provocando a sua volatização e, consequentemente, a maior demanda por agrotóxicos. A eliminação da cobertura vegetal do solo pela queimada favorece, além disso, a formação de processos erosivos na época de chuvas (Szmrecányi, 1994, p. 74; Coelho et al., 2010, p. 244).

Essas questões levaram ao surgimento de leis de proibição do uso do fogo como método despalhador e facilitador do corte de cana-de-açúcar nos âmbitos federal e estadual. O Decreto Federal no 2.661/1998 estabeleceu que o emprego do fogo deve ser eliminado a cada período de cinco anos em um quarto das áreas mecanizáveis, ou seja, naquelas áreas com declividades inferiores a 12\%. Determinou, portanto, que o uso do fogo fosse totalmente proscrito do processo de limpeza dos canaviais até 2018.

Além disso, especificou áreas onde o fogo deve ser suprimido, como as próximas aos perímetros urbanos, rodovias, ferrovias, aeroportos, reservas florestais e unidades de conservação, entre outras.

Do mesmo modo, a legislação de vários estados seguiu as determinações da lei federal, sobretudo no que se refere à definição das áreas mecanizáveis e às faixas de proteção ao uso do fogo, entretanto, às vezes estendendo um pouco mais o limite temporal para a sua eliminação como método despalhador.

Foi o caso dos três estados maiores produtores de cana-de-açúcar no Brasil. Em São Paulo, a proibição da queima de cana-de-açúcar foi determinada antes mesmo do decreto federal, pelo Decreto-Lei de 16/04/1997. Atualmente, a Lei paulista $n^{0}$ 11.241/2002 dispõe sobre a eliminação gradativa da queima da palha da cana-de-açúcar, determinando que, em áreas mecanizáveis, ou seja, “em terrenos acima de 150 ha (cento e cinquenta hectares), com declividade igual ou inferior a $12 \%$ (doze por cento), em solos com estruturas que permitam a adoção de técnicas usuais de mecanização da atividade de corte de cana”, o emprego do fogo deve ser eliminado totalmente até 2021. Em áreas não mecanizáveis, ou seja, "em terrenos com declividade superior a 12\% (doze por cento), em demais áreas com estrutura de solo que inviabili- 
zem a adoção de técnicas usuais de mecanização da atividade de corte de cana”, o prazo é até 2031 (São Paulo, 2002, Artigo $2^{\circ}$ ).

Em Minas Gerais, a Deliberação Normativa Copam nº 133/2009 regulamentou a prática da queima de cana-de-açúcar, determinando que

Os produtores e empreendimentos consumidores de cana-de-açúcar implantados no Estado de Minas Gerais a partir de 2008, nas áreas com declividade inferior a 12\% (doze por cento), poderão utilizar a prática de queima controlada em no máximo 20\% (vinte por cento) de área a ser implantada, devendo esta prática ser eliminada na totalidade de área até o ano de 2014 (Copam, 2009, Art. $1^{\circ}$ ).

E também que

Nos empreendimentos implantados até 2007, inclusive com renovação de licença tanto das lavouras quanto da atividade industrial, em data posterior à restrição, a utilização da prática da queima da cana-de-açúcar nas áreas com declividade inferior a 12\% (doze por cento) deverá estar concluída no máximo até 2014. (Copam, 2009, Art. $2^{0}$ ).

Em Goiás, a Lei $\mathrm{n}^{0}$ 15.834/2006 dispôs que o uso do fogo como método de pré-colheita seja reduzido gradativamente em áreas mecanizáveis, sendo que em 2028 a eliminação deverá abranger 100\% da área cortada. Considerou áreas mecanizáveis as plantações em áreas acima de 15oha (cento e cinquenta hectares), cujos terrenos sejam contíguos e apresentem declividade inferior a 12\% (doze por cento), além de solos com estruturas que permitam a adoção de técnicas usuais de mecanização da atividade de corte de cana.

Essas normas, associadas ao incremento tecnológico de colhedoras, têm possibilitado o aumento da quantidade de cana colhida crua com manutenção da palhada no solo, cuja importância para a conservação das propriedades físicas, biológicas e químicas pedológicas tem sido referida em vários estudos. Pesquisas têm constatado o efeito da palha sobre o solo na disponibilização do nitrogênio 
para as plantas, na manutenção da temperatura e umidade do solo, na estabilidade de seus agregados e na velocidade de infiltração, bem como na redução da quantidade de gases emitidos. Com a mineralização gradativa da palha, uma parte consegue permanecer mais tempo no ambiente, garantindo o aumento do teor de matéria orgânica do solo (Cerri et al., 2010, p. 204).

Em termos industriais, a principal fonte de emissão de poluentes atmosféricos é a caldeira. Apesar de a maior parte operar utilizando como combustível o bagaço e não combustíveis fósseis, pode ainda assim emitir óxidos de nitrogênio e monóxido de carbono. Mas o poluente mais significativo é o material particulado, sobretudo poeira e fuligem, tendo em vista as outras emissões de poluentes serem irrelevantes, quando as caldeiras estão reguladas (Coelho et al, 2010, p. 245).

Nesse sentido, a Resolução Conama ${ }^{0}$ 436/2011, que complementou a 382/2006, estabeleceu os limites máximos de emissões de poluentes atmosféricos para fontes de combustão externa de biomassa de cana-de-açúcar a serem seguidos pelas indústrias.

Outro aspecto importante a ser considerado em relação às emissões atmosféricas relacionadas ao setor sucroenergético é que, apesar do Programa Nacional do Álcool (Proálcool) não haver sido criado com o objetivo de reduzir a poluição provocada pelos veículos automotores, o uso do etanol, seja diretamente ou misturado à gasolina, contribuiu significativamente para a redução de poluentes atmosféricos.

O etanol é um combustível de baixa toxidez e, diferentemente da gasolina, contém oxigênio em sua estrutura química, o que contribui para que a sua combustão no motor ocorra de forma mais completa e resulte em menos emissão de poluentes (Szwarc, 2010, p. 187).

$[\ldots]$

Dois tipos de etanol são utilizados como combustível nos motores de combustão interna: hidratado e anidro. O etanol hidratado contém aproximadamente 95\% de etanol em volume e o restante é água. É apropriado para uso como combustível exclusivo nos motores de ignição por faísca (motores do Ciclo Otto) e, se misturado com aditivos adequados ou utilizado em sistemas biocombustível, pode ser também usado em 
motores de ignição por compressão (motores do Ciclo Diesel). A produção do etanol anidro requer uma etapa adicional de desidratação, que segue a de destilação e o produto final contém o,4\% de água, em volume. (Szwarc, 2010, p. 187).

O etanol anidro é misturado em todas as gasolinas comercializadas em território brasileiro, com exceção da gasolina de aviação (Szwarc, 2010, p. 187). A Portaria n ${ }^{0}$ 75/2015 do Ministério de Agricultura, Pecuária e Abastecimento e a Resolução no 1/2015 do Conselho Interministerial do Açúcar e do Álcool (Cima) fixaram em $27 \%$ a porcentagem de etanol anidro na gasolina comum (gasolina $\mathrm{C}$ ) e de $25 \%$ na gasolina premium.

Sobretudo nas áreas urbanas, o uso de veículos origina altas concentrações de poluentes atmosféricos, tais como monóxido de carbono (CO), hidrocarbonetos ( $\mathrm{HC}$ ), óxidos de nitrogênio (NOx), óxidos de enxofre (SOx), material particulado (MP), ozônio troposférico (O3) e metais pesados - chumbo, níquel, cádmio e manganês (Szwarc, 2010, p. 187). Dessa forma, até meados da década de 1990, no auge do Proálcool, a utilização do etanol como combustível ou na mistura com a gasolina propiciou a redução da emissão desses poluentes atmosféricos.

Posteriormente, com o desenvolvimento dos veículos flex fuel, o uso de misturas de gasolina $\mathrm{C}$ e de etanol hidratado trouxe vantagens também, pois apesar da emissão de hidrocarbonetos ser equivalente entre a gasolina C e o etanol, "a emissão resultante do uso exclusivo de etanol apresenta menor toxidez e reatividade fotoquímica” (Szwarc, 2010, p. 189). Além disso, o uso de etanol possibilitou a eliminação de aditivos à base de chumbo utilizados para a elevação da octanagem da gasolina. "Pelo fato do etanol ter uma octanagem muito alta, a sua adição à gasolina em volumes elevados tornou desnecessário o uso desses aditivos, que em 1990 tiveram o seu uso banido" (Szwarc, 2010, p. 189).

Quanto à emissão de SOx, o uso do etanol contribui decisivamente para a redução da poluição do ar. Nos veículos a gasolina, a emissão de SOx é reduzida de $20 \%$ a $25 \%$, dependendo do teor de etanol no combustível. 
Caso o combustível utilizado seja exclusivamente etanol, a emissão de SOx chega a ser até 100 vezes menor que a da gasolina; nos veículos flex fuel, quanto maior o uso de etanol maior será a redução de SOx. Raciocínio análogo pode ser feito para diversos compostos orgânicos da gasolina que apresentam reatividade fotoquímica superior e são bastante tóxicos, caso do benzeno e do 1-3 butadieno. Como o etanol tem em sua fórmula apenas dois carbonos, a emissão de MP [material particulado] é praticamente nula (Szwarc, 2010, p. 191).

Em relação aos aldeídos ( $\mathrm{R}-\mathrm{CHO})$, tema que volta e meia retorna ao debate, é fato que a combustão do etanol os produz, assim como a gasolina, sobretudo o acetaldeído, que, no entanto, é menos tóxico que o formaldeído produzido pela combustão de combustíveis fósseis (Szwarc, 2010, p. 191). Szwarc (2010) complementa ainda que estudo realizado em 2003 por Abrantes (2003) constatou que veículos a diesel podem emitir até oito vezes mais aldeídos do que veículos a álcool e até 40 vezes mais do que aqueles que utilizam gasolina $\mathrm{C}$.

De fato, a partir do século XXI, com o advento mais acentuado das preocupações com as mudanças climáticas provocadas pelos gases de efeito estufa (GEEs) oriundos dos combustíveis fósseis, a produção do álcool combustível adquiriu um novo status no cenário político-econômico mundial. Apesar da combustão do etanol, assim como da gasolina, emitir substâncias tóxicas, embora em quantidade inferior, um dos aspectos positivos considerados por especialistas (Camargo et al., 2008, p. 47) que vem sendo sublinhado é também a contribuição dos canaviais para a redução dos GEEs, mediante a absorção de $\mathrm{CO} 2$ pela cana-de-açúcar durante o processo de fotossíntese.

Nesse sentido, uma questão polêmica que sempre surge em relação ao etanol é sobre a sua possibilidade de substituir os combustíveis derivados de petróleo. Mas o mais provável é que ele continue a se configurar como um combustível complementar a outros combustíveis, como ocorre atualmente, tendo em vista a sua dependência da safra da cana-de-açúcar e o destino industrial dessa matéria-prima ser determinado de acordo com os preços das commodities.

A última Conferência do Clima - COP24, realizada na Polônia, 
discutiu sobre o fim do uso de combustíveis fósseis e consensualmente indicou que as metas de redução dos gases de efeito estufa só poderão ser alcançadas com o uso de biocombustíveis. Considerando que, no ano de 2017 , apenas $13,8 \%$ da matriz energética mundial era baseada em fontes renováveis (Brasil, 2019, p. 22), existe uma grande janela de oportunidade para o uso do etanol como combustível mundial.

Mas o que se deve ponderar é que apesar do uso do etanol contribuir para atenuar os efeitos do uso de combustíveis fósseis, não deve ser considerado como a solução final, pois ele também gera emissões atmosféricas. Além disso, o seu uso demanda a fabricação e o consumo de veículos, os quais, para serem fabricados, requerem a extração de recursos naturais.

De acordo com a última estimativa anual de emissões de gases de efeito estufa do governo brasileiro (Brasil, 2016, p. 57), a produção de ferro-gusa e aço, no ano de 2014, emitiu 41.649 GgCO2 eq., ou seja, $44,18 \%$ de $\mathrm{CO} 2$ de todo o setor industrial brasileiro. Considerando-se que parcela dessa produção é voltada para a fabricação de veículos, inclusive dos flex, é interessante se refletir sobre a contribuição efetiva do uso de biocombustíveis, como o etanol, e sobretudo sobre a redefinição das políticas relacionadas aos padrões de consumo e produção atuais, que trariam talvez resultados mais efetivos sobre a questão do aquecimento global.

\section{c) Efluentes líquidos e captação de água}

Outro impacto significante da agroindústria canavieira está relacionado ao uso da água. A atividade demanda grandes quantidades de água, sobretudo no seu processo industrial. Não considerando o reúso da água, "O uso médio de uma usina que só produza açúcar é de $30 \mathrm{~m}^{3} / \mathrm{t}$ cana, de uma destilaria autônoma é de $15 \mathrm{~m}^{3}$ /t, e quando a usina destina 50\% da produção de cana para cada produto final (açúcar e álcool), a média de captação de água fica em torno de $21 \mathrm{~m}^{3} / \mathrm{t}$ cana" (Coelho et al., 2010, p. 246).

Destaca-se que a cana-de-açúcar, em grande parte do Brasil, com exceção do Nordeste e do Norte de Minas Gerais, é uma cultura de sequeiro, ou seja, não requer irrigação na maior parte do ano. No 
Centro-Sul, em algumas épocas, quando há longos períodos sem chuva, emprega-se a chamada "irrigação de salvação", para a garantia da brotação após o plantio da cana. Porém a maior parte da demanda hídrica é originada das necessidades industriais, sendo que grande parte da fração aquosa eliminada ao final do processo industrial é derivada da própria cana-de-açúcar, cujo peso é constituído em 70\% de água (Elias Neto, 2005, p. 108).

$\mathrm{Na}$ indústria, aproximadamente $87 \%$ da água é utilizada na lavagem de cana, na evaporação e vácuos, no resfriamento de dornas e nos condensadores de álcool (Elias Neto, 2005, p. 112). Devido à cobrança pelo uso da d'água e ao desenvolvimento de novas tecnologias, as indústrias investiram na racionalização do seu consumo com o reúso da água em sistemas de circuitos fechados e a eliminação da etapa de lavagem da cana, possibilitada pela mecanização, em que a sujidade causada pelo fogo deixou de existir. No corte mecanizado, a cana é limpa a seco, pois a lavagem da cana picada promove a perda de sacarose nos colmos, o que seria desvantajoso para a indústria (Coelho et al., 2010, p. 248).

Além da captação de água para os usos industrial e agrícola, os impactos provenientes da atividade nos recursos hídricos dizem respeito ao lançamento de efluentes nos corpos d'água. Os principais efluentes originados no processo de produção de açúcar e álcool são:

Água de lavagem de cana: 180 a 500 mg/l de DBO5 e alta concentração de sólidos. Tratada com decantação (lagoas) e lagoas de estabilização, para o caso de lançamento em corpos d'água. Na reutilização, o tratamento consiste em decantação e correção do pH entre 9 e 10.

Águas dos multijatos e condensadores barométricos: baixo potencial poluidor (10 a $40 \mathrm{mg} / \mathrm{DBO} 5)$ e alta temperatura $\left(\sim 50^{\circ} \mathrm{C}\right)$. Tratamento com tanques aspersores ou torres para resfriamento, com recirculação ou lançamento.

Águas de resfriamento de dornas e de condensadores de álcool: alta temperatura $\left(\sim 50^{\circ} \mathrm{C}\right)$. Tratamento com torres de resfriamentos ou tanques aspersores para retorno ou lançamento.

Vinhaça e águas residuárias: grande volume e carga orgânica (10,85 / 1 de álcool, com cerca de 175 g DBO5 / l de álcool). A vinhaça é aplicada 
na lavoura de cana conjuntamente com as águas residuárias (lavagem de pisos, purgas de circuitos fechados, sobra de condensados), promovendo a fertirrigação com aproveitamento dos nutrientes (Elias Neto, 2005, p. 114).

A vinhaça é um dos efluentes mais volumosos gerados na produção do álcool, com uma média de 13 litros para cada litro de álcool produzido (Coelho el al, 2010; Gonçalves, 2008) e de 6 a 8 litros para cada litro de cachaça (FEAM, 2013, p.65). A vinhaça “é um resíduo líquido de substâncias orgânicas com elevado teor de potássio. Seu pH varia entre 4,o e 5,o; é corrosivo, tem altos índices de [...] demanda química de oxigênio (DQO)" (Resende et al., 2002, p. 281). Apresenta DBO em torno de 20.000 a 35.000 mg.L e temperatura de saída do sistema de destilação em torno de 85 a $90^{\circ} \mathrm{C}$ (Gonçalves, 2009, p. 78). De acordo com Gonçalves (2008, p. 252), a vinhaça é cem vezes mais poluente que o esgoto doméstico e em termos de volume nas usinas sucroenergéticas só é ultrapassada pelo bagaço de cana.

Após décadas de lançamento nos corpos d'água ou nas chamadas áreas de sacrifício, provocando a sua contaminação, morte de peixes e incômodo à população do entorno devido ao mau cheiro, em 1978, a Portaria no 323 do Ministério do Interior proibiu o lançamento de vinhaça nos cursos d'água (Gonçalves, 2009, p. 78). A indústria passou então a utilizá-la como fertilizante nas lavouras de cana-de-açúcar, devido ao seu alto nível de potássio.

Ainda que não exista no Brasil nenhuma norma federal acerca dos critérios para a disposição da vinhaça, alguns estados procuraram estabelecer parâmetros para sua aplicação, transporte e armazenamento tendo em vista a sua nocividade ao meio ambiente, se aplicada de forma indevida. São os casos da Norma Técnica CETESB P4. 231/2015, em São Paulo, e da Deliberação Normativa Copam no 164/2011, em Minas Gerais.

De fato, apesar da fertirrigação apresentar benefício ambiental por ser um processo que evita a eliminação da vinhaça nos corpos d'água - e econômico, pois substitui parte dos fertilizantes potássicos -, é controverso o seu uso, haja vista que 
A vinhaça, largamente utilizada nas lavouras canavieiras possui, em grandes quantidades, elementos que, dependendo da concentração, [...] se destacam como contaminantes de águas superficiais e subterrâneas, como o fosfato e o nitrato, respectivamente. Esses elementos [...] têm gerado, nos últimos anos, grande preocupação acerca dos efeitos, principalmente do nitrato, na saúde da população humana e animal. Stevenson (1986) afirma que o impacto dos nitratos atinge não só a saúde humana e animal como, também, o crescimento (diminuto ou excessivo) das plantas e a qualidade do ambiente (eutrofização) (Silva et al, 2007, p. 111).

Não obstante, reconhece-se que a alta eficiência dos sistemas de tratamento de efluentes, acima de 98\%, juntamente com a biodigestão da vinhaça e o emprego da fertirrigação, possibilitou a redução considerável dos impactos ambientais no meio físico e biótico provocados pela agroindústria sucroenergética.

\section{d) Resíduos sólidos}

Além das emissões atmosféricas e dos efluentes líquidos, a agroindústria canavieira produz resíduos sólidos. Na fase industrial, a moagem de uma tonelada de cana produz uma média de $280 \mathrm{~kg}$ de bagaço (Dantas, 2009, p. 38), dos quais aproximadamente 95\% são totalmente aproveitados na cogeração energética.

Além do bagaço, são produzidos de 20 a $40 \mathrm{~kg}$ de torta de filtro, derivados da etapa de filtragem do caldo das moendas, e $25 \mathrm{~kg}$ de cinzas por tonelada de bagaço queimado nas caldeiras. A torta de filtro "apresenta em torno de 70\% de água e teores médios de 80; 1,4; 1,0; 0,7; 5,0; 1,4 e 19\% (base seca) de matéria orgânica, $\mathrm{N}, \mathrm{P}_{2} \mathrm{O}_{5}, \mathrm{~K}_{2} \mathrm{O}, \mathrm{CaO}, \mathrm{MgO}, \mathrm{S}$ e cinzas" (Coelho et al., 2010, p. 249). As cinzas, subproduto da queima do bagaço,

apresentam, em média, 85\% de $\mathrm{SiO} 2$, 0,9\% de $\mathrm{P} 2 \mathrm{O} 2$, 7\% de $\mathrm{K} 2 \mathrm{O}$ e 0,6\% de $\mathrm{MgO}$, podendo ser utilizadas diretamente no solo ou incrementando a composição química de compostos orgânicos. Outro resíduo gerado nas usinas é a fuligem de chaminés que são lavadas normalmente com 
água de reúso aproveitada da lavagem de cana. A composição da fuligem é semelhante à da cinza qualitativamente e mais diluída quantitativamente, pois apresenta 305 a $70 \%$ de água. (Coelho et al., 2010, p. 249).

Ambos os resíduos são muitas vezes utilizados diretamente nos campos de cultivo como fertilizantes. Contudo é mais indicado que haja a sua compostagem previamente, pois melhora as suas características físicas e químicas, reduzindo o teor de água e favorecendo a sua distribuição no campo (Coelho et al, 2010, p. 249).

$\mathrm{Na}$ fase agrícola, a colheita mecanizada de um hectare de cana gera em torno de 8 a 15 toneladas de palhas e pontas (Coelho et al., 2010, p. 248) ou $140 \mathrm{~kg}$ de palha por tonelada de cana moída (Dantas, 2009, p. 38).

A palha é constituída das pontas e folhas da cana crua, ficando, atualmente, em muitas propriedades, depositada sobre o solo como cobertura, para a prevenção de processos erosivos, a manutenção da microbiota do solo e o retorno de nutrientes e a redução da incidência luminosa, o que dificulta a fotossíntese e a germinação de ervas daninhas (Coelho et al., 2010, p. 248/251).

Contudo a manutenção da cobertura vegetal no campo de cultivo pode causar a proliferação da cigarrinha da raiz e muitas vezes facilita a propagação do fogo, que pode chegar até as matas. Além desses potenciais efeitos adversos, a aplicação da vinhaça sobre a palha tem sido apontada como um dos fatores que levam à proliferação da Stomoxys calcitrans, popularmente conhecida como mosca-do-estábulo ou mosca-do-bagaço, nas propriedades rurais, sobretudo em pecuárias e suiniculturas próximas aos canaviais cuja colheita é mecanizada.

A mosca-de-estábulo é uma espécie hematófoga associada há séculos aos animais domésticos, podendo também afetar os seres humanos, mas cuja população se mantinha em equilíbrio, com níveis de infestação reduzidos (Koller et al, 2009, p. 8-9). É capaz de transmitir vários patógenos, como os nematoides que causam a habronemose gástrica e/ ou cutânea dos equinos e parasitam a cavidade peritoneal de ruminantes; os vírus da anemia infecciosa equina, do Trypanosoma evansi e do Trypanosoma vivax; e da mosca-do-berne (Koller et al, 2009, p. 17). 
Dependendo do grau de infestação dos animais domésticos, pode haver uma redução de peso em torno de $15 \%$ a $20 \%$ e da produção de leite de 40\% a 60\% (Koller et al, 2009, p. 17).

Surtos dessa mosca têm sido registrados na última década em São Paulo, Mato Grosso do Sul, Minas Gerais e Goiás (Koller et al, 2009, p. 10; Cançado e Barros, 2015), próximos a áreas canavieiras, associados à intensa pluviosidade, elevada temperatura e ao uso da vinhaça e torta de filtro sobre a palha de canaviais mecanizados, criando um ambiente favorável à sua proliferação.

Para o seu controle, algumas usinas e pecuaristas têm aplicado cal virgem nas áreas de empoçamento de vinhaça e onde há acúmulo de urina e fezes de animais (Koller et al, 2009, p. 21). Pesquisadores (Koller et al, 2009; Cançado et al. 2013) consideram o uso de inseticidas pouco eficiente, além dos riscos ambientais desconhecidos que podem ser originados. Portanto, afirmam que o mais adequado para o controle da multiplicação dessa espécie de mosca, devido à aplicação de vinhaça, é a adoção de medidas preventivas. Koller et al. (2009), revistos por Cançado et al. (2013), sugerem:

- De modo geral, boas práticas sanitárias devem ser adotadas na propriedade, a higiene local através da limpeza sistemática de dejetos animais e resíduos alimentares é fundamental, principalmente em sistemas de confinamento e produção leiteira;

- Após sua remoção, dejetos e resíduos orgânicos devem ser adequadamente armazenados e tratados (compostagem). Recomenda-se, sempre que possível, cobrir o material com plástico/ lona preta (o) para matar as larvas existentes e impedir novas posturas. Evitando seu acúmulo ou espalhamento natural e possível formação de áreas de criação de larvas;

- Eliminar o uso de cama de frango em áreas consideradas de risco (entorno de usinas sucroalcooleiras). Outros adubos orgânicos devem ser evitados e sua utilização deve ser monitorada com relação à presença de larvas;

- Evitar o acúmulo de umidade próximo a locais de armazenamento de resíduos e dejetos, realizar a drenagem do terreno, eliminar vazamentos nos bebedouros e reservatórios de água; 
- Reduzir o volume de vinhaça aplicada nos canaviais, ou parcelar este volume, de modo a permitir maior rapidez na absorção pelo solo e reduzir riscos de empoçamento em áreas de deposição de palha;

- Vistoriar as áreas após aplicação de vinhaça em até 48 horas para verificar possíveis locais de empoçamento e tomar providências imediatas para sua completa drenagem;

- Evitar a aplicação de vinhaça em locais previamente encharcados pela chuva;

- Revolver todo o material da torta de filtro duas vezes por semana de modo a obter uma mistura homogênea e evitar o acúmulo de umidade na base das leiras, para tanto é necessário regular a altura das leiras e o equipamento, de modo que o mesmo se mantenha rente ao solo durante a operação (Cançado et al., 2013, p. 3).

Acrescentam ainda que o fogo pode ser utilizado como profilaxia, auxiliando na eliminação dos criadouros dessas moscas em áreas de canaviais nos períodos de maior risco de infestação, enquanto outras técnicas de controle não se encontrarem disponibilizadas (Cançado et al.; 2013, p. 2). É preciso lembrar que a chamada queima profilática só é possível mediante autorização dos órgãos ambientais competentes.

\section{e) Mudanças no uso da terra}

O incremento da produção de etanol na primeira década do século XXI, com a instalação de novas usinas, principalmente em Goiás, Minas Gerais, Mato Grosso do Sul e São Paulo, provocou mudanças no uso da terra e na estrutura produtiva desses estados. Devido ao custo do transporte da cana até as plantas industriais e à perda de sacarose, com um maior o tempo decorrido entre o seu corte e esmagamento, a implantação de uma nova usina envolve consequentemente o avanço da cana-de-açúcar, de forma contínua, no entorno onde a usina se instala.

A produtividade média da cana-de-açúcar, em 1998, era de 65 
ton/ha (Coelho et al.; 2006, p. 26). O uso de melhores variedades, mais bem adaptadas às diferentes condições ambientais e mais resistentes, associado às inovações tecnológicas no campo, fez com que essa produtividade aumentasse para algo em torno de 85 ton./ha em 2014 (Mapa, 2015).

Até o início da primeira década de 2000, essas melhorias sucessivas permitiram o crescimento do plantio da cana sem a excessiva expansão territorial, da mesma forma ocorrendo com as áreas de outros produtos agrícolas, que se mantiveram estáveis. No entanto, a partir do ano de 2002/2003, esse quadro se alterou (Figura 23). As áreas de plantio de soja têm apresentado significativo aumento, o que foi acompanhado pelo incremento do cultivo de cana-de-açúcar. Desde 2015, a área plantada de cana tem sofrido declínio, ao passo que as áreas de plantio de milho, que tinham sido bastante reduzidas, têm tido um grande incremento, após o período entre 2010 e 2015. As áreas plantadas com laranja têm se mantido estabilizadas, enquanto as áreas de plantio de feijão e de arroz apresentaram uma leve queda nos últimos anos.

De fato, a produtividade da cana-de-açúcar tem se reduzido nos últimos anos, chegando na safra de 2018/19 a 72 ton/ha. O período de crise do setor afetou a renovação dos canaviais e reduziu o investimento em pacotes tecnológicos, mantendo as médias brasileiras de produtividade inferiores a 80 ton/ha e as áreas de plantadas em ritmo menor (Companhia Nacional de Abastecimento, 2019; Mapa, 2015).

Entretanto muitas discussões se acirraram acerca do deslocamento ou da substituição das atividades agropecuárias, principalmente de culturas alimentares, pela cana-de-açúcar; do efeito da expansão canavieira na concentração fundiária e na inviabilização da agricultura familiar, dentre outros impactos econômicos e sociais. Ambientalistas, a mídia e pesquisas destacam com veemência os impactos adversos do cultivo de "monoculturas energéticas" (Assis e Zucarreli, 2007), inclusive da cana-de-açúcar, no território nacional, salientando o seu impacto sobre a segurança ou a soberania alimentar da população. 
Figura 23. Área plantada (ha) de diferentes cultivos agrícolas no Brasil, 19902017.

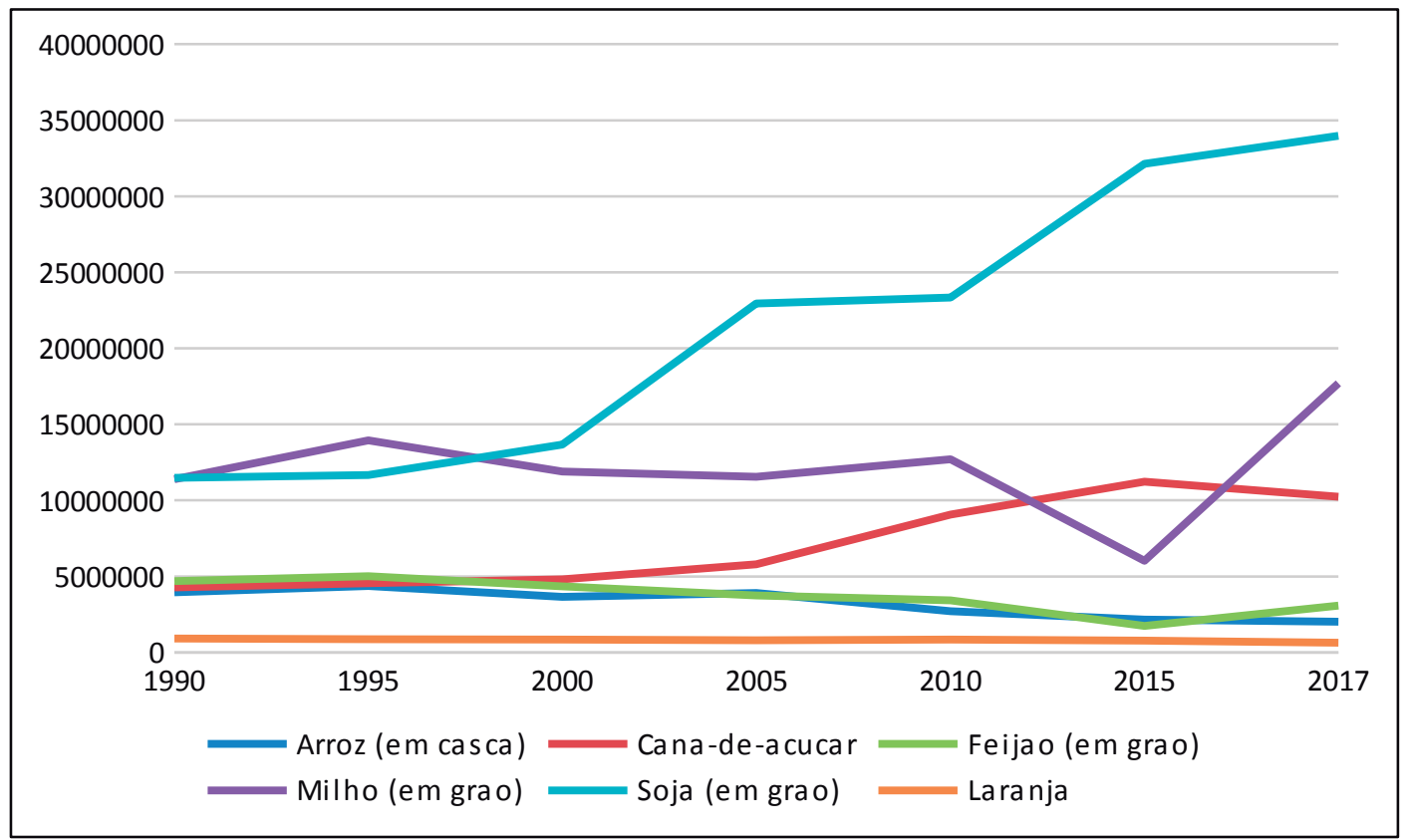

Fonte: Produção Agrícola Municipal (PAM), IBGE, 1990-2017. Org.: dos autores, 2019.

Nesse sentido, Cleps (2009, p. 251) afirma que a expansão da cana, na safra 2007/2008, nos estados de Mato Grosso, Minas Gerais, Mato Grosso do Sul e Goiás, ocorreu principalmente sobre as pastagens e em menor escala sobre lavouras de soja e milho, o que se reflete na bovinocultura e na produção de leite.

Assis e Zucarelli (2007) observam da mesma forma que na região do Triângulo Mineiro, no Oeste paulista e em Mato Grosso do Sul, entre 2003 e 2005, pastagens foram convertidas em canaviais, o que, segundo os autores, pode possivelmente ter implicado na redução do número de bovinos e na produção de leite (Assis e Zucarelli, 2007, p. 06).

Cleps (2009, p. 251) complementa que, no mesmo período, a área plantada com cana em Uberlândia teve um aumento de 13\%, e, em Uberaba, de 99\%, enquanto o rebanho nos dois municípios mineiros sofreu uma redução da ordem de 6\% e 18\%, respectivamente. Ressalta ainda que nesse período nas "mesmas regiões que estão vivendo a grande expansão da cana estão tendo grandes quedas na produção de alimentos. A produção de feijão, por exemplo, caiu 68\% em Uberlândia e 60\% em São José do Rio Preto” (Cleps, 2009, p. 252-253). 
Em consonância, Castro et al. (2007) concluíram, em estudo sobre a expansão do setor sucroalcooleiro em Goiás, que, no ano de 2007, $60 \%$ das usinas em operação em instalação ou em processo de licenciamento ambiental estavam localizadas em áreas de agricultura.

Por outro lado, Rosillo-Calle (2010) afirma que uma característica comum dos estudos e da mídia quando ressaltam os potenciais impactos negativos da produção de matéria-prima para a produção de biocombustíveis é a falta de dados científicos de longo prazo que apoiem suas teses. Observa nesse sentido que

A competição direta por terra é um mito, ao invés de ser realidade, considerando que mero $1 \%$ da área global de terras em uso agrícola no mundo é presentemente dedicado aos biocombustíveis. Há mais de $2 \mathrm{Gh}$ [2 milhões de hectares] de terras superexploradas, mais de 700 Mha de outro tipo de terras que poderiam ser usadas para finalidades não alimentares sem afetar a produção de alimentos (Rosillo-Calle, 2010, p. 101).

Na mesma direção, Coelho et al. consideram que

Land area available for biofuels must not depend on deforestation nor competition with food. Sugarcane crops create no pressure for Amazon deforestation, particulary because this crop is not suitable enough for production in that region (Coelho et al, 2006, p. 29).

Contudo, Cleps (2009) lembra que apesar dos dados do IBGE não provarem que a pecuária do Centro-Sul está sendo expulsa para a região amazônica por causa da expansão da cultura canavieira, pelo menos há uma conexão entre as duas dinâmicas.

Por outro lado, constatou-se em observações de campo no Norte Fluminense e na Zona da Mata pernambucana, em janeiro de 2016, que um processo inverso estava ocorrendo com a substituição da cana-de-açúcar pela pecuária. No Norte Fluminense, desde 2002, a Usina de Quissamã deixou de operar, restando atualmente apenas as suas ruínas (Figura 24). Nos últimos anos, o processo de fechamento das usinas na região se tornou mais intenso quando importantes usinas deixaram 
de operar, como a de Barcelos (desde a safra de 2009/2010), Cupim (2006), a de Carapebus (desativada em 2009) e a de São José/Coagro (2015). Não tendo onde comercializar a cana-de-açúcar, os pequenos e médios fornecedores da região retiraram a cana e a substituíram pela pecuária, atividade que era predominante no século XVII.

Figura 24. Companhia Engenho Central de Quissamã, ruínas do primeiro Engenho Central brasileiro, janeiro de 2016.

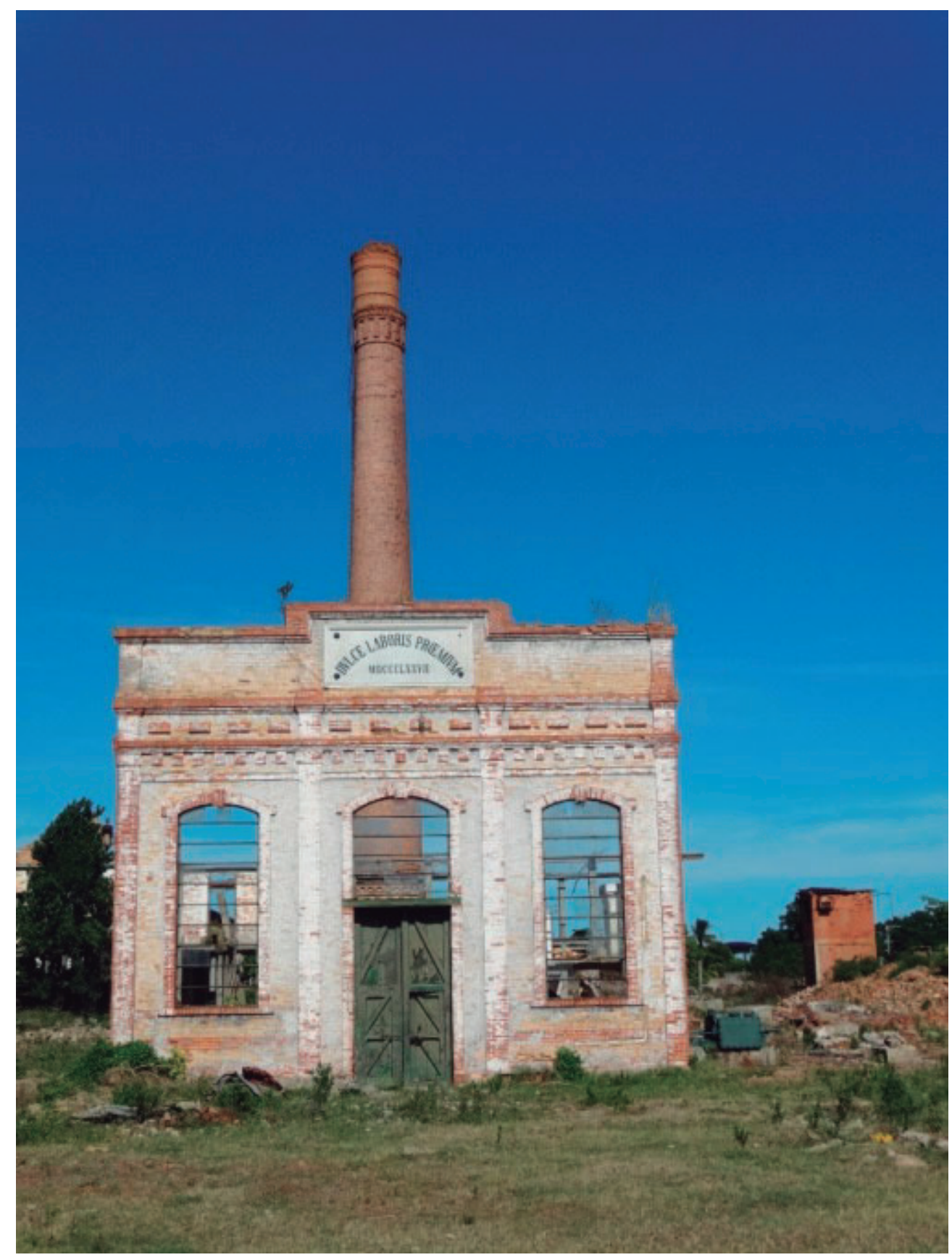

Fonte: acervo dos autores, 2016. 
Outra questão controversa é o aumento do uso de agrotóxicos quando implantadas as fazendas de cana-de-açúcar. Arrigoni e Almeida afirmam que "O consumo de inseticidas, fungicidas, acaricidas e outros defensivos na cultura da cana-de-açúcar no Brasil é inferior ao das culturas de citros, milho, café e soja. [...] O consumo de fungicidas é praticamente nulo e o de inseticidas é relativamente baixo" (Arrigoni e Almeida, 2005, p. 148).

Por outro lado, Macedo (2005, p. 164) considera que ainda se utiliza mais herbicidas na cana do que no café e no milho, menos do que na citricultura e o equivalente ao utilizado na soja. Da mesma forma, a aplicação de agrotóxicos e fertilizantes em diversas fases do cultivo da cana, associada ao desmatamento de matas ciliares e à lixiviação do solo adubados quimicamente, tem sido indicada em algumas pesquisas e documentos como potencial gerador de contaminações em vários graus dos recursos hídricos próximos às plantações de cana-de-açúcar (Corbi et al, 2006). Além disso, embora não haja estudos conclusivos sobre os efeitos dos agrotóxicos utilizados na cana-de-açúcar sobre a fauna, casos de enfraquecimento e perdas de colônias de abelhas têm sido registrados em áreas próximas a canaviais.

\section{f) Erosão dos solos}

A erosão é um processo natural de liberação e arraste de partículas do solo e de nutrientes causada, nas áreas intertropicais, sobretudo pela ação das chuvas, e intensificada pela interferência humana por meio de atividades como a retirada da vegetação original e da sua substituição por plantios agrícolas.

A erosão hídrica pode ocorrer de várias formas, mas os solos cultivados tropicais estão mais sujeitos à erosão laminar, a qual corresponde à remoção das camadas superficiais do solo com a ação das chuvas de forma difusa, sem canais definidos, sendo pouco perceptível. Ao causar a lavagem da superfície do solo, a água carrega a sua parte mais fértil, provocando queda na produtividade e no transporte do material até os corpos d'água, podendo causar assoreamento. Bertoni e Lombardi Neto (2012. p. 68), citando Marques (1949), afirmam que o Brasil perde cerca de 500 milhões de toneladas de terra anualmente por erosão 
laminar, sendo que a sua magnitude depende principalmente das características pedológicas, topográficas, pluviométricas e de manejo de solo e da cultura.

As áreas de canaviais também estão sujeitas à erosão. Scarpinella e outros (2013), baseados em Telles (1999), apontaram que áreas de cana-de-açúcar apresentam uma perda de solo de 12,4 t.ha-1.ano-1, enquanto em áreas de soja essa perda é de 20,1; nas de milho, 12; nas de café e reflorestamento, o,9; e em áreas de pastagem, o,4. Rossetto (2010, p. 385) discriminou que as perdas de solo por erosão em áreas de cana-de-açúcar podem variar de 6,5 t.ha $^{-1}$.ano ${ }^{-1}$, com palhada na superfície, a 108,6 t.ha ${ }^{-1}$.ano ${ }^{-1}$, em área de cultivo sem palhada.

Assim, as tecnologias empregadas na conservação do solo das áreas cultivadas são um dos fatores diferenciais para a menor intensidade dos processos erosivos. A colheita mecanizada ou o corte da canade-açúcar sem emprego de fogo possibilita a manutenção do palhiço, o qual, durante a estação chuvosa, amortece o impacto das gotas de chuva no solo e contribui para a melhor infiltração da água, auxiliando na conservação do solo.

Além das áreas de cultivo propriamente ditas, os carreadores, vias de acesso por onde as gruas carregadoras e caminhões de transbordo transitam entre os talhões de cana e os setores da fazenda, são sem cobertura vegetal. Scarpinella e outros (2013), estudando 130 fazendas canavieiras em São Paulo, indicaram que a área média de carreadores em fazendas de cana-de-açúcar gira em torno de $5 \%$ da propriedade. Dessa forma, a sua implantação em áreas declivosas, com sistemas de drenagem e revestimento inadequados, torna a erosão hídrica significativa nos períodos de chuva. 


\section{CONCLUSÃO:}

\section{FINAL SEM FIM}

Enfim, o que fez com que a cana-de-açúcar, ao longo de cinco séculos, se mantivesse como um dos principais cultivos agrícolas no Brasil? Desde a sua introdução em solo brasileiro, aspectos econômicos e políticos, internos e externos, características físicas dos diversos ambientes por onde se propagou e diferentes técnicas e tecnologias empregadas condicionaram sua retração ou expansão, provocando impactos socioambientais diferenciados no tempo e no espaço.

O cenário geográfico, histórico e econômico da expansão da cana-de-açúcar no Brasil, apresentado ao longo dos capítulos, permitiu observar o envolvimento das questões ambientais em todas as fases do seu percurso no território brasileiro. Matas foram e continuaram a ser derrubadas para a implantação dos engenhos banguês e de usinas. Corpos d'água serviram como mananciais de abastecimento para a produção sucroalcooleira e como receptores das águas servidas da indústria. Solos foram intensamente utilizados e desgastados pela erosão, sobretudo nos relevos de colinas e morros baixos, e modificados, com a utilização de adubos, para o cultivo da cana.

No terceiro quartel do século XX, em meio ao clima mundial de crise ambiental e diante do acirramento das discussões sobre os efeitos de uma ótica desenvolvimentista sobre o meio ambiente, uma crescente preocupação em relação aos impactos decorrentes da atividade sucroalcooleira tomou corpo, sobretudo a partir da década de 1990.

Sob o incentivo do Proálcool, o aumento da produção de etanol 
trouxe como consequência o crescimento da produção de vinhaça, lançada em corpos d'água e em áreas de sacrifício ambiental, o que provocou impactos de grande magnitude, nos anos de 1970 e 1980, nas regiões canavieiras. Da mesma forma, o uso do fogo como método despalhador, a partir da década de 1950, afetava os solos, a atmosfera e a saúde da população do entorno e dos trabalhadores. Tais questões passaram a aparecer nos meios de comunicação e provocavam grande reação no público em geral, nos meios científico e político.

Apesar de o meio empresarial tentar até então se furtar das suas responsabilidades em relação aos problemas ambientais, posicionando-os como externalidades prejudiciais ao pleno desenvolvimento do setor e da própria economia do país, a pressão popular e governamental, tanto interna como externa, acabaram por vencer essa resistência, a qual foi ajustada por meio de uma estratégia considerada como alternativa para lidar com tais questões: o desenvolvimento sustentável.

Paulatinamente, o uso de novas tecnologias no setor permitiu a minimização gradativa dos fatores impactantes ao meio ambiente. As questões socioambientais passaram a ser orientadas para a sustentabilidade. Sustentabilidade essa entendida sob uma abordagem tecnocêntrica, em que tecnologias limpas e end-of-pipe possibilitam o tratamento de efluentes líquidos, o controle de emissões atmosféricas e o reúso da água e do bagaço de cana.

O investimento nessas novas tecnologias tornou-se extremamente vantajoso, pois ao mesmo tempo em que evita a transgressão das normas ambientais, economiza recursos financeiros com o reúso da água, a cogeração de energia baseada na biomassa, a substituição do homem pela máquina e o uso da vinhaça como fertilizante.

A utilização de outros insumos, como colheitadeiras no campo, possibilitou a eliminação do fogo, mas ao mesmo tempo trouxe outras exigências em relação ao uso da terra pelos canaviais, já que a máquina só consegue ser bem utilizada em relevos com declividades até $12 \%$. Dessa forma, apesar de o emprego de diferentes tecnologias ter possibilitado o uso de solos menos férteis, o relevo e a proximidade com os corpos d'água se mantiveram como fatores determinantes para a lo- 
calização dos canaviais e, consequentemente, das usinas. Declividades superiores a $12 \%$ impedem ou dificultam o uso de máquinas agrícolas como colheitadeiras, e a água é o elemento primordial, tanto para a produção agrícola da cana como para a industrialização do açúcar e do etanol.

Normas foram editadas no sentido de regulamentar essas questões. Inquietações socioambientais, associadas à expressividade do setor na economia brasileira, se materializaram também em instrumentos orientativos do Estado, tais como o Zoneamento Agroecológico da Cana-de-Açúcar (ZAEcana) e os Zoneamentos Ecológicos-Econômicos estaduais, que incorporaram cenários sobre a expansão territorial da cana-de-açúcar, direcionando os investimentos, no início do século XXI, para determinadas regiões, como foi o caso do Triângulo Mineiro e do Sudeste de Goiás.

O setor sucroenergético, desde 2017, vem passando por um período de ajustes. A elevação dos preços internacionais do açúcar e o retorno da paridade dos preços da gasolina com os valores internacionais, com o consequente aumento do uso do etanol pelo consumidor, contribuíram para o aumento do faturamento das empresas e para a quitação parcial de suas dívidas. Ao final de 2017, foi publicada a Política Nacional de Biocombustíveis - RenovaBio, que junto com os fatos anteriores, poderá se refletir na recuperação da produtividade agrícola e industrial do setor na região Centro-Sul.

Portanto, assim como ocorreu em toda a sua história de expansão no território brasileiro, a distribuição geográfica da cana, e da economia a ela associada, se modificou nas últimas décadas. Desde o período colonial, a expansão da economia canavieira havia estabelecido uma divisão regional: o Norte/Nordeste e o Centro Sul, destacando-se o primeiro em termos de volume de produção. A divisão continua a existir em termos produtivos e de inserção tecnológica, contudo a balança pende para o Centro-Sul.

O uso de sistemas de irrigação e de colheita manual faz com que a produção do Norte/Nordeste seja distinta da do Centro-Sul, onde a cultura de cana-de-açúcar é de sequeiro e há o predomínio da colheita mecanizada. No Centro-Sul, a mecanização avançou grandemente des- 
de os anos de 1960, enquanto no Nordeste caminhou a passos mais vagarosos, o que se refletiu na produtividade agrícola média dos estados produtores das duas regiões. São Paulo apresentou, em 2018, o rendimento de 76,2 t/ha, enquanto Alagoas, 53,7 t/ha.

A produção pernambucana, que desde meados do século XVII até 1950, foi sempre a maior no território nacional, foi superada pela produção de São Paulo, Minas Gerais, Goiás, Paraná, Mato Grosso do Sul, Alagoas e Mato Grosso. Portanto, os cinco maiores produtores de cana-de-açúcar estão na região Centro-Sul. Atualmente, áreas tradicionais canavieiras, sobretudo na Zona da Mata pernambucana e na planície norte-fluminense, deram lugar à pecuária bovina. No Centro-Sul, inversamente, onde as condições de relevo e solos permitem, foram as pastagens que cederam lugar aos canaviais.

Nesses mais de cinco séculos da presença da cana-de-açúcar no território brasileiro, a agroindústria do açúcar, e depois sucroalcooleira, transformou-se em agroindústria sucroenergética, onde a produção de energia elétrica baseada na biomassa assume cada vez mais relevante papel na cadeia produtiva da cana-de-açúcar. A produção de açúcar, álcool e energia sempre foi e continua sendo determinada pela oscilação dos preços dos produtos. Entretanto, atualmente, com uma planta multifuncional, com destilarias e usinas de cogeração de energia acopladas às indústrias de açúcar, as grandes empresas do setor possuem maior autonomia para driblar os períodos de baixos preços dos produtos, com o encaminhamento da sua matéria-prima para a produção do que é mais valorizado no mercado em dado momento, tanto interna como externamente.

O desenvolvimento da pesquisa nos permite apontar três grupos de mudanças que sempre marcaram a história do uso da cana-de-açúcar na manufatura e na industrialização: mudanças no setor industrial, mudanças no setor agrícola e mudanças na organização social da produção, que se materializam diferentemente no tempo e no espaço. É da natureza dessa herbácea provocar mudanças. Mudanças essas que perpassaram o período colonial e imperial - com seus engenhos rudimentares -, avançaram no início do período republicano - com a ideia dos engenhos centrais e a implantação das usinas - para chegar 
ao século XXI com uma série de possibilidades no campo do açúcar, do etanol, da energia e da cachaça. Possibilidades que, durante mais de cinco séculos, impactaram e continuam impactando o ambiente com intensidades e formas diferentes e que se manifestam no espaço, numa convivência harmônica ou desarmônica, mas que resultam naquilo que se pode denominar de uma geografia brasileira da cana-de-açúcar. 


\section{REFERÊNCIAS}

AB’SÁBER, A. Fundamentos geográficos da história brasileira. In: HOLANDA, S. B.; CAMPOS, P. M. (org.). História geral da civilização brasileira: a época colonial: do Descobrimento à expansão territorial. 13. ed. São Paulo: Bertrand Brasil, 2003. Tomo I. v.1.

AB'SÁBER, A. N. Os domínios de natureza no Brasil: potencialidades paisagísticas. São Paulo: Ateliê Editorial, 2003.

AB'SÁBER, A. N. A evolução geomorfológica. In: AZEVEDO, A. de (coord.). A baixada santista: aspectos geográficos. São Paulo: Edusp, 1965. v. 1. p. 49-66.

AB'SÁBER, A. N. A terra paulista. Boletim Paulista de Geografia. São Paulo: AGB, 1956. p. 5-38.

ABARCA, C. D. G. Inovações tecnológicas na agroindústria da cana-de-açúcar no Brasil. In: ENCONTRO NACIONAL DE ENGENHARIA DE PRODUÇÃO, 19., 1999. Rio de Janeiro. Anais [...]. Rio de Janeiro: Abepro, 1999. Disponível em: https://www.agencia. cnptia.embrapa.br/Repositorio/ENEGEP1999 A0105 ooofxgg417302wyiv80soht9h4y xjyhn.pdf. Acesso em: 20 set. 2015.

ABREU, J. C. Capítulos de história colonial. Belo Horizonte: Itatiaia, 1988.

AÇÚCAR GUARANI acelera ida à bolsa. O Globo. Rio de Janeiro. 21 jun. 2007.

AÇÚCAR GUARANI fica com 50\% da Usina Vertente. Estadão. São Paulo. 24 fev. 2010.

ADM. ADM in Brazil. [s.d.]. Disponível em: https://www.adm.com/adm-worldwide/brazil. Acesso em: 20 nov. 2015.

AGÊNCIA NACIONAL DE ENERGIA ELÉTRICA (Brasil). Banco de informações de ge- 
ração 2015. Brasília, DF: ANEEL, 2015. Disponível em: www.aneel.gov.br. Acesso: 15 de dezembro de 2015.

AGÊNCIA NACIONAL DE ENERGIA ELÉTRICA (Brasil). Resolução normativa $n^{\circ}$ 235, de 14 de novembro de 2006. Estabelece os requisitos para a qualificação de centrais termelétricas cogeradoras de energia e dá outras providências. Brasília, DF: Aneel, 2006.

AGÊNCIA NACIONAL DO PETRÓLEO (Brasil). Resolução $n^{o}$ 19/2015. Brasília, DF: ANP, 2015. Disponível em: http://legislacao.anp.gov.br/?path=legislacao-anp/resol-anp/2015/abril\&item=ranp-19-2015. Acesso: 20 mar. 2016.

ALMEIDA, Irene Maria Gatti de. Gomose da cana-de-açúcar no Brasil. In: REUNIÃO ITINERANTE DE FITOSSANIDADE DO INSTITUTO BIOLÓGICO 9, 2003, São Paulo. Anais [...]. Fortaleza: Instituto Biológico, 2003. Disponível em: http://www.biologico. sp.gov.br/rifib/IX_RIFIB/almeida1.PDF. Acesso em: 09 abr. 2015.

ALVES, F. Por que morrem os cortadores de cana? Revista Saúde e Sociedade. São Paulo, v.15. n. 3, 2006.

AMADOR, E. S. Baía de Guanabara: um balanço histórico. In: ABREU, Maurício de Almeida. Natureza e sociedade no Rio de Janeiro. Rio de Janeiro: Biblioteca Carioca, 1992.

AMATO NETO, João. A indústria de máquinas agrícolas no Brasil: origens e evolução. Revista da Administração de Empresas, São Paulo, v. 25. n. 3, jul/set de 1985.

ANDRADE, Gilberto Osório de. O ciclo da cana-de-açúcar no Rio Grande do Norte. Revista de História da USP, São Paulo, n. 35, p. 123-129, $3^{\circ}$ trimestre de 1958.

ANDRADE, M. C. A terra e o homem no Nordeste: contribuição ao estudo da questão agrária no Nordeste. 7. ed. São Paulo: Cortez, 2005.

ANDRADE, M. C. Espaço e tempo na agroindústria canavieira de Pernambuco. Estudos Avançados, São Paulo, n. 15, v. 43, p. 267-28o, 2001.

ANDRADE, M. C. Modernização e pobreza: a expansão da agroindústria canavieira e seu impacto ecológico e social. São Paulo: Unesp, 1994.

ARAÚJO, T. B. Os engenhos centrais e a produção açucareira no recôncavo Baiano. Salvador: Federação das Indústrias do Estado da Bahia, 2002. 
ARRIGONI, E. B.; ALMEIDA, L. C. Defensivos (pesticidas e outros). In: MACEDO, I. C. (org.). A energia da cana-de-açúcar: doze estudos sobre a agroindústria da cana-de-açúcar no Brasil e a sua sustentabilidade. São Paulo: União da Agroindústria Canavieira do Estado de São Paulo, 2005.

ASSIS, W. F. T.; ZUCARELLI, M. C. Despoluindo incertezas: impactos territoriais da expansão das monoculturas energéticas no Brasil e replicabilidade de modelos sustentáveis de produção e uso de biocombustíveis. [S.l.], Setembro de 2007. Disponível em: http:// www.natbrasil.org.br/Docs/biocombustiveis/expansao biocombustiveis brasil.pdf. Acesso em: o9 fev. 2010.

AUDE, M. I. S. Estádios de desenvolvimento da cana-de-açúcar e suas relações com a produtividade. Ciência Rural, Santa Maria, v. 23, n. 2, p. 241-248, 1993.

BARICKMAN, B. J. Um contraponto baiano: açúcar, fumo, mandioca e escravidão no Recôncavo, 1780-1860. Rio de Janeiro: Civilização Brasileira, 2003.

BARROS, G. S. C. Mercado de Trabalho do agronegócio brasileiro: a dinâmica dos empregos formais na agroindústria sucroenergética de 2000 a 2016. Edição Especial do CEPEA, Piracicaba, v. 1, n. 2, 2018.

BERNARDES, L. M. C. Função defensiva do Fio de Janeiro e seu sítio original. In: BERNARDES, LYSIA M. C.; SOARES, M. T. S. Rio de Janeiro: Cidade e Região. RJ: Secretaria Municipal de Cultura, 1995.

BERTONI, J.; LOMBARDI NETO, F. Conservação do solo. SP: Ícone, 2012.

BRASIL. Decreto 4.297 de 2002. Regulamenta o art. 9o, inciso II, da Lei no 6.938, de 31 de agosto de 1981, estabelecendo critérios para o Zoneamento Ecológico-Econômico do Brasil - ZEE, e dá outras providências. Brasília, DF: Presidência da República, 2002. Disponível em: http://www.planalto.gov.br/ccivil 03/decreto/2002/D4297.htm

BRASIL. Decreto $n^{o}$ 51.104/1961. Cria o Fundo de Recuperação da Agro-Indústria Canavieira e dá outras providências. Brasília, DF: Presidência da República,1961.

BRASIL. Decreto-Lei $n^{\circ}$ 1. 130/1939. Aprova as quotas pelo Instituto do Açúcar e do Álcool. Brasília, DF: Presidência da República, 1939c.

BRASIL. Decreto-Lei $n^{\circ}$ 1. 546/1939. Prorroga o regime do art. $4^{0}$ do Decreto n. 24.749 estipulando novas condições. Brasília, DF: Presidência da República, 1939d. 
BRASIL. Decreto-Lei $n^{o}$ 1. 669/1939. Dispõe sobre a fixação de quotas de produção de açúcar. Brasília, DF: Presidência da República, 1939b.

BRASIL. Decreto-Lei $n^{\circ}$ 1. 831/1939. Dispõe sobre a defesa da produção do açúcar e dá outras providências. Brasília, DF: Presidência da República, 1939a.

BRASIL. Decreto-Lei $n^{o} 22.981 / 1933$. Modifica o decreto $n^{0} 22.789$ e aprova o respectivo regulamento e dá outras providências. Brasília, DF: Presidência da República, 1933.

BRASIL. Decreto-Lei $n^{\circ}$ 3. 855/1941. Dispõe sobre desapropriações por utilidade pública. Brasília, DF: Presidência da República, 1941.

BRASIL. Decreto-Lei $n^{0}$ 644/1938. Amplia as atribuições do Instituto do Açúcar e do Álcool e dá outras providências. Brasília, DF: Presidência da República, 1938.

BRASIL. Decreto-Lei $n^{\circ}$ 9.827/1946. Dispõe sobre a produção açucareira e dá outras providências. Brasília, DF: Presidência da República, 1946.

BRASIL. Lei n ${ }^{\circ} 8.178 / 1991$. Estabelece as regras sobre preços e salários e dá outras providências. Brasília, DF: Presidência da República, 1991.

BRASIL. Lei $n^{\circ}$ 4.870/1965. Dispões sobre a produção açucareira, a receita do Instituto do Açúcar e do Álcool e sua aplicação, e dá outras providências. Brasília, DF: Presidência da República, 1965.

BRASIL. Lei $n^{\circ}$ 76.593/1975. Institui o Programa Nacional do Álcool e dá outras providências. Brasília, DF: Presidência da República, 1975.

BRASIL. Ministério da Agricultura, Pecuária e Abastecimento. Anuário estatístico da agroenergia 2014. Brasília, DF: Ministério da Agricultura, Pecuária e Abastecimento, 2015.

BRASIL. Ministério da agricultura, pecuária e abastecimento. Instrução Normativa $n^{o}$ 13. Brasília, DF: MAPA, 2005.

BRASIL. Ministério da Ciência, Tecnologia e Inovação. Estimativas anuais de emissões de gases de efeito estufa no Brasil. Brasília, DF: MCTI, 2016.

BRASIL. Ministério de Minas e Energia. Resenha Energética Brasileira: exercício de 2018. Brasília, DF: Ministério de Minas e Energia, 2019.

256 A trajetória da cana-de-açúcar no Brasil 
BRAY, Sílvio Carlos; FERREIRA, Enéas Rente; RUAS, Davi Guilherme G. As políticas da agroindústria canavieira e o Proálcool no Brasil. Marília, SP: Unesp Marília, 2000.

CACHAÇA sem mistério. Revista Pesquisa Fapesp, São Paulo, n. 87, maio 2013.

CAMARGO, A. M. M. P.; CASER, D. V.; CAMARGO, F. P.; OLIVETTE, M. P. A.; SACHS, R. C. C.; TORQUATO, S. A. Dinâmica e tendência da expansão da cana-de-açúcar sobre as demais atividades agropecuárias, Estado de São Paulo, 2001-2006. Informações Econômicas, [s.l.] v. 38, n. 3. SP: Governo do Estado de São Paulo, mar. 2008.

CAMELINI, J. H.; CASTIlLLO, R. Etanol e uso corporativo do território. Mercator, Ceará, v. 11, n. 25, p. 7-18, 2012.

CANABRAVA, Alice P. A grande lavoura. In: HOLANDA, Sérgio Buarque e CAMPOS, Pedro Moacyr (org.). História geral da civilização brasileira: o brasil monárquico 4: declínio e queda do império. São Paulo: Difusão Europeia do Livro, 1971. Tomo II.

CANAONLINE. Biomassa é opção em crise energética. Disponível em: www.canaonline. com.br/conteudo/biomassa-e-opcao-em-crise-energetica.html. Acesso: 05 mar. 2016.

CANÇADO, P.; BARROS, A. T. M. Surtos da mosca-dos-estábulos próximos a usinas de cana-de-açúcar. [s.l.], 2015. Disponível em: https://https://www.embrapa.br/buscade-noticias/-/noticia/2649716/artigo-surtos-da-mosca-dos-estabulos-proximos-a-usinas-de-cana-de-acucar. Acesso em: 16 jan. 2016.

CANÇADO, P.; BARROS, A. T. M.; CATTO, J. B.; KOLLER, W. W.; SOARES, C. O. Uso da queima profilática no controle emergencial e prevenção de surtos pela mosca-dos-estábulos (Stomoxys calcitrans) em propriedades produtoras de cana-de-açúcar. Comunicado Técnico 126, Campo Grande, ago. 2013. Disponível em: https://ainfo.cnptia.embrapa.br/ digital/bitstream/item/92013/1/COT126.pdf. Acesso em: 30 jun. 2017.

CARVALHO, C. P. O. Novas estratégias competitivas para o novo ambiente institucional: o caso do setor sucroalcooleiro em Alagoas: 1990/2001. In: MORAES, M. A. F. D.; SHIKIDA, P. F. A. (org.). Agroindústria canavieira no Brasil: evolução, desenvolvimento e desafio. São Paulo: Atlas, 2002.

CASTRO, J. Geografia da fome. Rio de Janeiro: Cruzeiro, 1946.

CASTRO, S. S.; BORGES, R. O.; SILVA, R. A. A.; BARBALHO, M. G. S. Estudo da expan- 
são da cana-de-açúcar de açúcar no estado de Goiás: subsídios para uma avaliação do potencial de impactos ambientais. In: FORUM DE C\&T NO CERRADO: Impactos econômicos, sociais e ambientais no cultivo da cana-de-açúcar de açúcar no território goiano. Goiânia: SBPC, 2007. p. 9-17.

CERRI, C. C.; FEIGL, B. J.; GALDOS, M. V.; BERNOUX, M.; CERRI, C. E. P. In: CORTEZ, L. A. B. (coord.). Bioetanol de cana-de-açúcar: P\&D para produtividade e sustentabilidade. São Paulo: E. Blucher, 2010.

CESAR, M. A.; SILVA, F. C. Pequenas indústrias rurais da cana-de-açúcar: melado, rapadura e açúcar mascavo. Rio de Janeiro: Embrapa, [20--?]. Disponível em: wwww. agencia.cnptia.embrapa.br/Repositorio/Pequenasindustriasrurais oooft7j8ao102wyiv8oukmovf7omegy1.pdf. Acesso em: 16 de fevereiro de 2019.

CLEPS JR, J. Concentração de poder no agronegócio e (des)territorialização: os impactos da expansão recente do capital sucroalcooleiro no triângulo mineiro. Caminhos de geografia: revista on line, Uberlândia, v. 10, n. 31, set/2009. Disponível em: http://www. seer.ufu.br/index.php/caminhosdegeografia/article/viewFile/16152/9091. Acesso em: 21 jan. 2016.

COELHO, S. T.; GOLDEMBERG, J.; LUCON, O; GUARDABASSI, P. Brazilian sugarcane ethanol: lessons learned. Energy for Sustainable Development, v. X, n. 2. Philadelphia, EUA: Elsevier, June 2006.

COELHO, S. T.; LORA, B. A; GUARDABASSI, P. M. Aspectos Ambientais da Cadeia do Etanol de Cana-de-açúcar no Estado de São Paulo. In: CORTEZ, L. A. B. (coord.). Bioetanol de cana-de-açúcar: P\&D para produtividade e sustentabilidade. São Paulo: E. Blucher, 2010.

COMISSÃO DE POLÍTICA AMBIENTAL (MG). Deliberação Normativa $n^{0}$ 133/20o9. Convoca os municípios com população entre vinte e trinta mil habitantes ao licenciamento ambiental de sistemas adequados de tratamento ou destinação final de resíduos sólidos urbanos. Belo Horizonte: COPAM, 2009. Disponível em: http://www.siam.mg.gov.br/ sla/download.pdf?idNorma=8570. Acesso: 13 fev. 2016.

COMPANHIA NACIONAL DE ABASTECIMENTO (Brasil). Acompanhamento da safra brasileira de cana-de-açúcar. Safra 2018/19. Brasília, DF: Conab, 2019. v. 5.

CORBI, J. J.; STRIXINO, S. T; SANTOS, A.; DEL GRANDE, M. Diagnóstico ambiental 
de metais e organoclorados em córregos adjacentes a áreas de cultivo de cana-de-açúcar (Estado de São Paulo, Brasil). Química Nova, São Paulo, v. 29, n. 1, jan/fev 2006, p. 61-65.

CORREAA NETO, V. Análise de viabilidade da cogeração de energia elétrica em ciclo combinado com Gaseificação de Biomassa. 2001. Dissertação (Mestrado) - Universidade Federal do Rio de Janeiro, Rio de Janeiro, 2001.

COSTA, E. V. O escravo na grande lavoura. In: HOLANDA, S. B.; CAMPOS, P. M. (org.). História geral da civilização brasileira: o Brasil monárquico: reações e transações. São Paulo: Difusão Europeia do Livro, 1969.

DANTAS, P. L. Análise de Custo na Geração de Energia com Bagaço de Cana-de-Açúcar: um estudo de caso em quatro usinas de São Paulo. 2009. Dissertação (Mestrado em Energia) - Universidade de São Paulo, São Paulo, 2009.

DEAN, Warren. A ferro e fogo. A história e a devastação da Mata Atlântica brasileira. São Paulo: Companhia das Letras, 1996.

DIEGUES JUNIOR, M. O Banguê nas Alagoas: traços da influência do sistema econômico do engenho de cana-de-açúcar na vida e na cultura regional. Rio de Janeiro: IAA, 1949.

EGLER, C. A. Bioenergia e transição energética. In: BERNARDES, J. A; SILVA, C. A.; ARRUZO, R. C. Espaço e energia: mudanças no paradigma sucroenergético. Rio de Janeiro: Lamparina, 2013. p. 31-41.

EISENBERG, P. L. Modernização sem mudança: a indústria açucareira em Pernambuco, 1840-1910. Rio de Janeiro: Paz e Terra. Campinas: Universidade Estadual de Campinas, 1977.

ELIA NETO, A. Aspectos da legislação ambiental para o setor da cana-de-açúcar. In: ÚNICA. MACEDO, I. C. A Energia da Cana-de-Açúcar: doze estudos sobre a agroindústria da cana-de-açúcar no Brasil e a sua sustentabilidade. São Paulo: Unica, 2005. p. 76-78.

EMBRAPA. Zoneamento agroecológico da cana-de-açúcar. Rio de Janeiro: Embrapa Solos, 2009. (Embrapa Solos. Documentos 110).

ENGEMANN, C.; CHAGAS, J.; SANTOS, R. S.; BORGES, A. C.; OLIVEIRA, R. O. Consumo de recursos florestais e produção de açúcar no período colonial: o caso do Engenho do 
Camorim, RJ. In: OLIVEIRA, R. R. As marcas do homem na floresta: história ambiental de um trecho urbano de mata atlântica. Rio de Janeiro: Ed. PUC-Rio, 2010.

EPE. Balanço energético nacional 2018: ano base 2017. Rio de Janeiro: EPE - Empresa de Pesquisa Energética, 2019.

ESTRANGEIROS são a nova geração de usineiros. O Globo, Rio de Janeiro, Economia, 27 abr. 2013.

EU BEBO, sim. Valor Econômico, São Paulo, 05 fev. 2016. Disponível em: https://valor. globo.com/eu-e/noticia/2016/02/05/eu-bebo-sim.ghtml. Acesso em: 03 mar. 2017.

FAO. Crop yield response to water. Italy: FAO, 2012.

FEAM. Plano de ação para adequação ambiental do setor de aguardente e cachaça artesanal no Estado de Minas Gerais. Belo Horizonte: FEAM, 2013.

FERLINI, Vera Lúcia Amaral. A civilização do açúcar (séculos XVI a XVIII). São Paulo: Brasiliense, 1984 .

FERNANDES, Hamilton. Açúcar e álcool: ontem e hoje. Coleção Canavieira, Rio de Janeiro, n. 4, 1971.

FERREIRA, Aurélio B. H. Novo dicionário Aurélio da língua portuguesa. Curitiba: Positivo, 2009.

FERREIRA, Olavo Leonel. História do Brasil. São Paulo: Ática, 1996.

FRAGINALS, R. M. O engenho: complexo sócio-econômico açucareiro cubano. São Paulo: Hucitec; Editora Unesp, 1988.

FRIEDAM, F. Donos do Rio em nome do rei: uma história fundiária da cidade do Rio de Janeiro. Rio de Janeiro: Jorge Zahar, 1999.

FUNES-MONZOTE, R. De los bosques a los cañaverales: uma historia ambiental de Cuba 1491-1926. Cuba: Editorial de Ciencias Sociales, 2008.

FURTADO, A. (coord.). Capacitação tecnológica, competitividade e política industrial: uma abordagem setorial e por empresas líderes. Texto para discussão IPEA $n^{o} 348$. Brasília: IPEA, 1994. 
FURTADO, C. Formação econômica do Brasil. São Paulo: Nacional, 1969.

GAMA, R. Engenho e tecnologia. São Paulo: Duas Cidades, 1979.

GASCHO, G. J.; SHIH, S. F. Sugarcane. In: TEARE, I. D.; PEET, M. M. (ed.). Crop-water relations. New York: Wiley-Interscience, 1983. p. 445-479.

GEERLIGS, H. C. P. The World's Cane Sugar Industry: Past and Present. USA: Cambridge University Press, 1912.

GONÇALVES, D. B. Considerações sobre a expansão recente da lavoura canavieira no Brasil. Informações Econômicas, São Paulo, v. 39, n. 10, out. 2009.

GONÇALVES, D. B.; FERRAZ, J. M. G.; SZMRECÁNYI, T. O etanol e as alternativas aos combustíveis de origem fóssil. In: ALVES, F.; FERRAZ, J. M. G.; PINTO, L. F. G.; SZMRECÁNYI, T. Certificação socioambiental para a agricultura: desafios para o setor sucroalcooleiro. Piracicaba, SP: Imaflora; São Carlos, SP: EdUFSCar, 2008.

GONÇALVES, F. A. Condições de vida do trabalhador rural da zona da mata do estado de Pernambuco. Boletim do Instituto Joaquim Nabuco de Pesquisas Sociais, Recife, n. $15,1966$.

GUEDES, S. N. R; GALLO, Z.; MARTINS, L. A. T. P. Passado, presente e futuro da agroindústria canavieira do Brasil: uma reflexão a partir da perspectiva do desenvolvimento sustentável. In: MORAES, Márcia A. F. D. e SHIKIDA, Pery Francisco A. (org.). Agroindústria canavieira no Brasil: evolução, desenvolvimento e desafio. São Paulo: Atlas, 2002.

GUERRA, I. A. L. T. Tipos de clima do Nordeste. Revista Brasileira de Geografia, Rio de Janeiro, ano XVII, n. 4, 1955.

HEREDIA, B. A. Formas de dominação e espaço social: a modernização da agroindústria canavieira em Alagoas. São Paulo: Marco Zero; Brasília, DF: MTC/CNPq, 1998.

HOLANDA, S. B. Caminhos e fronteiras. 3. ed. São Paulo: Companhia das Letras, 1994.

HOLANDA, S. B. Raízes do Brasil. 26. ed. São Paulo: Companhia das Letras, 1995.

IBGE. A geografia da cana-de-açúcar. Rio de Janeiro: IBGE, 2017. 
IBGE. Anuário Estatístico do Brasil - 1979. Rio de Janeiro: IBGE, 1979.

IBGE. Anuário Estatístico do Brasil - 198o. Rio de Janeiro: IBGE, 1980.

IBGE. Anuário estatístico do Brasil 2018. Rio de Janeiro: IBGE, 2019. v. 78.

IBGE. Projeto RADAMBRASIL. Folha SD.24 Salvador. Rio de Janeiro: IBGE, 1981b.

IBGE. Projeto RADAMBRASIL. Folhas SB.24/25 Jaguaribe/Natal. Rio de Janeiro: IBGE, 1981a.

IBGE. Projeto RADAMBRASIL. Folhas SC.24/25 Aracaju/Recife. Rio de Janeiro: IBGE, $1983 a$.

IBGE. Projeto RADAMBRASIL. Folhas SF.23/24 Rio de Janeiro/Vitória. Rio de Janeiro: IBGE, $1983 \mathrm{~b}$.

IMPERIAL INSTITUTO FLUMINENSE. Revista Agrícola, Rio de Janeiro, Edição oo1, n.5. 1882. Disponível em: http://memoria.bn.br/pdf/188409/per188409 188200001. pdf. Acesso em: maio de 2015.

INCRA. Instrução Normativa $n^{o} 76 / 2013$. Dispões sobre a aquisição e arrendamento de imóvel rural por pessoa natural estrangeira residente no país e pessoa jurídica estrangeira autorizada a funcionar no Brasil e dá outras providências. Brasília, 23 ago. 2013.

INSTITUTO DE AÇÚCAR E ÁLCOOL. (Brasil). Brasil/Açúcar. RJ: IAA, 1972. (Coleção Canavieira n. 8).

INSTITUTO DE PESQUISAS TECNOLÓGICAS (SP). Mapa Geomorfológico do Estado de São Paulo. SP: IPT, 1981.

JAPAN INTERNACIONAL COOPERATION AGENCY. The Study on Management and Improvement of the Environmental Conditions of Guanabara Bay of Rio de Janeiro, The Federative Republic of Brazil. Rio de Janeiro: Interim Report. 2002.

KOLLER, W. W.; CATTO, J. B.; BIANCHIN, I.; SOARES, C.O.; PAIVA, F.; TAVARES, L. E.R.; GRACIOLLI, G. Surtos da Mosca-dos-estábulos, Stomoxys calcitrans, em Mato Grosso do Sul: novo problema para as cadeias produtivas da carne e sucroalcooleira?: Documentos 175. Campo Grande, MS: Embrapa Gado de Corte, 2009. 
LAMEGO, A. R. O homem e o brejo. Rio de Janeiro: CNG/IBGE, 1945.

LIMA, J. P. R.; SICSÚ, A. B. Zona da Mata pernambucana: Diversificação Produtiva ou Retomada da Cana-de-açúcar? In: MORAES, Márcia A. F. D.; SHIKIDA, Pery Francisco A. (org.). Agroindústria canavieira no Brasil: evolução, desenvolvimento e desafio. São Paulo: Atlas, 2002.

LIMA, P. C. R. Os carros flex fuel no Brasil. Brasília, DF: Câmara dos Deputados, 2009.

MACEDO, I. C. (org.). A energia da cana-de-açúcar: doze estudos sobre a agroindústria da cana-de-açúcar no Brasil e a sua sustentabilidade. São Paulo: Berlendis \& Vertecchia; UNICA, 2005.

MACHADO, S. S. Tecnologia da fabricação do açúcar. Inhumas: Instituto Federal de Educação, Ciência e Tecnologia, 2012. Apostila.

MACIEL, Telmo Frederico do Rego. Nível de vida do trabalhador rural da zona da mata. Recife: Instituto Joaquim Nabuco de Pesquisas Sociais, 1964.

MAZOYER, M.; ROUDART, L. História das agriculturas no mundo: do neolítico à crise contemporânea. São Paulo: UNESP; Brasília, DF: Nead, 2010.

MEIRA, R. B. Banguês, engenhos centrais e usinas: o desenvolvimento da economia açucareira em São Paulo e a sua correlação com as políticas estatais (1875-1941). São Paulo: Alameda, 2010.

MELLO, E. C. O bagaço da cana. São Paulo: Penguin Classics/Cia. Das Letras, 2012.

MELO, J. E. O açúcar no café: agromanufatura açucareira e modernização em São Paulo (1850-1910). 2009. Tese (Doutorado) - Universidade de São Paulo, São Paulo, 2009.

MELO, M. L. Açúcar e o homem: problemas sociais e econômicos do Nordeste canavieiro. Recife, PE: Instituto Joaquim Nabuco de Pesquisas Sociais, 1975.

MELO, M. L. Bases geográficas dos problemas do Nordeste. Revista Brasileira de Geografia, Rio de Janeiro, ano XXIV, n. 4, out.-dez. 1962, p. 503-541.

MINTZ, S. W. O poder amargo do açúcar: produtores escravizados, consumidores proletarizados. Recife, PE: Editora Universitária UFPE, 2003. 
MORAES, M. A. F. D. A desregulamentação do setor sucroalcooleiro do Brasil. São Paulo: Caminho Editorial, 2000.

MÜLLER, G. Complexo agroindustrial e modernização agrária. São Paulo: Hucitec, 1989.

NEVES, M. F.; TROMBIN, V. G. A dimensão do setor Sucroenergético: mapeamento e quantificação da safra 2013/14. Ribeirão Preto: Markestrat, Fundace, FEARP/USP, 2014.

OLALDE, A. R. Capacitação tecnológica na agroindústria canavieira: o caso da COPERSUCAR. 1992. Dissertação (Mestrado) - Departamento de Política Científica e Tecnológica do Instituto de Geociências, Universidade Estadual de Campinas, Campinas, 1992.

OLIVEIRA, C. R. et al. Cachaça de alambique: manual de boas práticas ambientais e de produção. Belo Horizonte: Seape, jun. 2005. Disponível em: http://www.feam.br/images/stories/arquivos/Manual de Cachaca 040805.pdf. Acesso em: 19 jun. 2015.

OLIVEIRA, L. V. O período colonial. In: INSTITUTO DO AÇÚCAR E ÁLCOOL (Brasil). Brasil/Açúcar. Rio de Janeiro: Ministério da Indústria e Comércio - MIC/IAA, 1972.

OLIVEIRA, P. [Produção de etanol de segunda geração na GranBio]. São Miguel do Campos, 28 jan. 2016. Depoimento concedido à Gelze Serrat de Souza Campos Rodrigues.

OSCAR, J. Escravidão e engenhos: Campos, São João da Barra, Macaé, São Fidélis. Rio de Janeiro: Achiamé, 1985.

PARA Lula, usineiros são heróis mundiais. Estadão, São Paulo, v. n. caderno, mar. 2007.

PENHA, A. L. N. Nas águas do canal: política e poder na construção do Canal Campos - Macaé (1835-1875). Tese (Doutorado) - Universidade Federal Fluminense, Rio de Janeiro, 2012.

PENTEADO, A. R. A Ilha de São Vicente. In: AZEVEDO, A. A Baixada Santista: aspectos geográficos: Santos e as cidades balneárias. São Paulo: Edusp, 1965.v. III.

PERRUCI, G. A república das usinas. Rio de Janeiro: Paz e Terra, 1978.

PETRONE, M. T. S. A lavoura canavieira em São Paulo: expansão e declínio (1765-1851). Tese (Doutorado) - Universidade de São Paulo, São Paulo, 1964. 325 p. 
PETRONE, P. Povoamento e caminhos nos séculos XVI e XVII. In: AZEVEDO, A. A Baixada Santista: aspectos geográficos. Povoamento e população. São Paulo: Edusp, 1965. v. II.

PILETTI, N. História do Brasil. São Paulo: Ática, 1996.

PINA, H. A agroindústria açucareira e sua legislação. São Paulo: APEC, 1972.

PORTO-GONÇALVES, C. W. A globalização da natureza e a natureza da globalização. Rio de Janeiro: Civilização Brasileira, 2012.

PRADO JR, C. História econômica do Brasil. 26. ed. São Paulo: Brasiliense, 1981.

QUEIROZ NETO, J. P.; KÜPPER, A. Os solos. In: AZEVEDO, A (coord.). A Baixada Santista: aspectos geográficos: as bases físicas. São Paulo: Edusp, 1965. p. 67-92. v. 1.

RAMOS, P. Heterogeneidade e integração produtiva na evolução recente da agroindústria canavieira do Centro-Sul (1985-2000). In: MORAES, M. A. F. D.; SHIKIDA, P. F. A. (org.). Agroindústria canavieira no Brasil: evolução, desenvolvimento e desafio. São Paulo: Atlas, 2002.

RAMOS, P. Um estudo da evolução e da estrutura da agroindústria canavieira do estado de São Paulo (1930-1982). 1983. Dissertação (Mestrado) - FGV, São Paulo, 1983.

REIS, N. G. Os engenhos da baixada santista e os do litoral norte de São Paulo. Revista USP, São Paulo, n. 41, p. 62-73, mar./maio 1999. Disponível em: http://www.usp.br/ revistausp/41/02-aziz.pdf. Acesso em: 02 fev. 2015.

RESENDE, M.; CURI, N.; REZENDE, S. B.; CORREAA, G. F. Pedologia: base para distinção de ambientes. Viçosa, MG: Neput, 2002.

RFA. 2019 Ethanol Industry Outlook. USA: RFA, 2019.

RIPOLI, T. C. C.; RIPOLI, M. L. C. Biomassa de cana-de-açúcar: colheita, energia e ambiente. Piracicaba: T.C.C. Ripoli, 2009.

ROSILLO-CALLE, F. Alimentos versus combustíveis: podemos evitar o conflito? In: CORTEZ, L. A. B. (coord.). Bioetanol de cana-de-açúcar: P\&D para produtividade e sustentabilidade. São Paulo: Blucher, 2010. 
ROSS, J. L. S. Ecogeografia do Brasil: subsídios para planejamento ambiental. São Paulo: Oficina de Textos, 2006.

ROSS, J. L. S. Ecogeografia. Palestra proferida em 19 de novembro de 2015. Uberlândia: UFU/IG, 2015 .

ROSS, J. L. S.; MOROZ, I. C. Mapa geomorfológico do Estado de São Paulo 1:500.ooo. São Paulo: Fapesp, 1997. v. II.

SACHS, R. C. C. Remuneração da tonelada de cana-de-açúcar no Estado de São Paulo. Informações Econômicas, Instituto de Economia Agrícola, São Paulo, v. 37, n. 2, 2007.

SÁNCHEZ, L. E. Avaliação de impacto ambiental: conceitos e métodos. São Paulo: Oficina de Textos, 2008.

SANTOS, M. H. de C. Avaliação político-institucional como uma medida da resolução de conflitos. In: ENCONTRO ANUAL DA ANPOCS. 11, Águas de São Pedro. Anais [...]. Águas de São Pedro: Anpocs, 1987.

SÃO PAULO. Lei $n^{o}$ 11.241, de 19 de setembro de 2002. Dispõe sobre a eliminação gradativa da queima da palha da cana-de-açúcar e dá providências correlatas. São Paulo: Governo do Estado de São Paulo, 2002.

SÃO PAULO. Secretaria de infraestrutura e meio ambiente. Zoneamento agroambiental do estado de São Paulo [online]. São Paulo: Secretaria de Infraestrutura e Meio Ambiente, 2019. Disponível em: www.infraestruturameioambiente.sp.gov.br/etanolverde/ zoneamento-agroambiental. Acesso: 02 jun. 2019.

SCARPINELLA, G. D.; MIRANDA, R. B.; MAUAD, F. F. Carreadores da cultura da cana-de-açúcar: vantagens e desvantagens do tratamento do subleito. Revista Brasileira de Ciências Ambientais, Rio de Janeiro, n. 29. Rio de Janeiro: Associação Brasileira de Engenharia Sanitária e Ambiental, 2013.

SCHLESINGER, S. Lenha nova para velha fornalha: a febre dos agrocombustíveis. Rio de Janeiro: FASE, 2008.

SCHWARCZ, L. M.; STARLING, H. M. Brasil: uma biografia. São Paulo: Companhia das Letras, 2015.

SCHWARTZ, S. B. A Commonwealth within itself: the early brazilian sugar industry, 1550-1670. Revista de Índias, Madrid, Espanha, v. LXV, n. 233, p. 79-116, 2005.

266 - A trajetória da cana-de-açúcar no Brasil 
SCHWARTZ, S. B. Segredos internos: engenhos e escravos na sociedade colonial. São Paulo: Companhia das Letras, 1988.

SHIKIDA, P. F. A. A evolução diferenciada da agroindústria canavieira no Brasil de 1975 a 1995. Cascavel, PR: Edunioeste, 1998.

SHIKIDA, P. F. Expansão canavieira no Centro-Oeste: limites e potencialidades. Revista de Política Agrícola, [s.l.], ano 22, v. 2, abr./mai./jun. 2013, p. 122-137.

SILVA, M. A. S.; GRIEBELER, N. P.; BORGES, L. C. Uso de vinhaça e impactos nas propriedades do solo e lençol freático. Revista Brasileira de Engenharia Agrícola e Ambiental, Campina Grande, v. 11, n. 1. Campina Grande, p. 108-114, 2007.

SILVA, P. R. P. O açúcar no norte fluminense. Histórica, São Paulo, v. 08, 2006. Disponível em: http://www.historica.arquivoestado.sp.gov.br/materias/anteriores/edicaoo8/ materia02/texto02.pdf. Acesso em: 13 jun. 2019.

SIMONSEN, Roberto. História Econômica do Brasil. 150o-1820. Brasília, DF: Senado Federal, 2005.

SOUZA, A. U. A questão da aquisição de terras por estrangeiros - um retorno aos dossiês. Agrária, São Paulo, n. 12, p. 3-113, 2010.

SOUZA, J. S. Uma empresa pioneira em São Paulo: o engenho central de Porto Feliz. São Paulo: USP/Museu Paulista, 1978. (Série de História, v. 7).

SUPER CANA. Folha de São Paulo, Mercado, 10 maio 2015.

SUPERINTENDÊNCIA DE ESTUDOS ECONÔMICOS E SOCIAIS DA BAHIA. Uso atual das terras: bacias do Recôncavo Norte e do Rio Inhambupe. Série Estudos e Pesquisas, Salvador, n. 64, 2003.

SZMRECSÁNYI, T. 1914-1939: crescimento e crise da agroindústria açucareira no Brasil. Revista Brasileira de Ciências Sociais, [s.l.], jun. 1988.

SZMRECSÁNYI, T. O planejamento da agroindústria canavieira do Brasil (1930-1975). Campinas: Hucitec, 1979.

SZWARC, A. O impacto do uso do etanol na qualidade do ar das grandes cidades. In: CORTEZ, L. A. B. Bioetanol de cana-de-açúcar: P\&D para produtividade e sustentabilidade. São Paulo: E. Blucher, 2010. 
TÁVORA, F. L. História e Economia dos Biocombustíveis no Brasil. Textos para Discussão 89. Brasília, DF: Centro de Estudos da Consultoria do Senado, abr. 2011.

VEIGA FILHO, A. A.; RAMOS, A. A. Proálcool e evidências de concentração na produção e processamento de cana-de-açúcar. Informações econômicas, São Paulo, v. 36, n. 7, p. 48-61, 2006.

VENCOVSKY, V. P. (2013). Setor sucroenergético: a emergência de um novo período. In: BERNARDES, J. A; SILVA, C. A.; ARRUZO, R. C. Espaço e energia: mudanças no paradigma sucroenergético. Rio de Janeiro: Lamparina, 2013. p. 51-62.

VIAN, C. E. F. Agroindústria canavieira: estratégias competitivas e modernização. Campinas: Átomo, 2003.

VIANA, S. B. R. O Engenho Central de Quissaman (1877/78-1904). 1881. Tese (Doutorado) - Universidade de São Paulo, São Paulo, 1981.

VICTOR, M. A. M. Cem anos de devastação: revisitada 30 anos depois. Brasília, DF: MMA, 2005.

VIEIRA, G. Avaliação do custo, produtividade e geração de emprego no corte de canade-açúcar, manual e mecanizado, com e sem queima prévia. 2003. Dissertação (Mestrado) - Faculdade de Ciências Agronômicas, Unesp, Botucatu, 2003.

WOLTERS, W. G. Sugar production in Java and in the Philippines during the nineteenth century. Philippine Studies, Philippines, v. 40, n. 4, p. 411-434, 1992. Disponível em: http://www.jstor.org/stable/42633336. Acesso em: 24 set. 2018. 

Sobre o livro

Formato $\quad 16 \mathrm{~cm} \times 23 \mathrm{~cm}$

Tipologia Georgia 
No ano de 2017, o Brasil se posicionou como 0 maior produtor mundial de cana-de-açúcar e de açúcar, e o segundo de etanol. 0 que explica essa constância da cana-de-açúcar e dos seus derivados nas pautas de produção e de exportação brasileiras? Quais são as condicionantes físicas que explicam a expansão dos canaviais e, consequentemente, das unidades manufatureiras e industriais do açúcar, etanol e agroenergia em certas regiōes do território brasileiro? Como esses determinantes, associados a fatores históricos, políticos e econômicos, levaram a arranjos territoriais e a impactos socioambientais diferenciados ao longo desses cinco séculos? Essas indagações nortearam o desdobramento dos temas tratados neste livro, descortinando um longo processo iniciado no período colonial, que aglutinou enorme quantidade de variáveis de abrangência política, econômica, social e tecnológica, ancoradas nas características físicas, sobretudo hidroclimatológicas, dos solos e do relevo das áreas onde a cana-de-açúcar, os engenhos e as usinas foram implantados. 